\section{Pacific Northwest}

National Laboratory

Operated by Battelle for the

U.S. Department of Energy

\title{
Survey of Radiological and Chemical Contaminants in the Near-Shore Environment at the Hanford Site 300 Area
}
G. W. Patton
B. L. Tiller
E. J. Antonio
T. M. Poston

\section{Pacific Northwest National Laboratory \\ Operated by Battelle for the \\ U.S. Department of Energy}

S. P. Van Verst

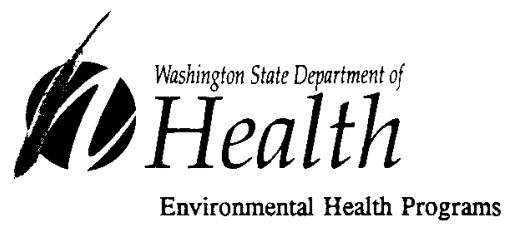

March 2003

Prepared for the U.S. Department of Energy under Contract DE-AC06-76RL01830 


\title{
DISCLAIMER
}

This report was prepared as an account of work sponsored by an agency of the United States Government. Neither the United States Government nor any agency thereof, nor Battelle Memorial Institute, nor any of their employees, makes any warranty, express or implied, or assumes any legal liability or responsibility for the accuracy, completeness, or usefulness of any information, apparatus, product, or process disclosed, or represents that its use would not infringe privately owned rights. Reference herein to any specific commercial product, process, or service by trade name, trademark, manufacturer, or otherwise does not necessarily constitute or imply its endorsement, recommendation, or favoring by the United States Government or any agency thereof, or Battelle Memorial Institute. The views and opinions of authors expressed herein do not necessarily state or reflect those of the United States Government or any agency thereof.

\author{
PACIFIC NORTHWEST NATIONAL LABORATORY \\ operated by \\ BATTELLE \\ for the \\ UNITED STATES DEPARTMENT OF ENERGY \\ under Contract DE-AC06-76RL01830
}

Printed in the United States of America
Available to DOE and DOE contractors from the Office of Scientific and Technical Information,
P.O. Box 62, Oak Ridge, TN 37831-0062;
ph: (865) 576-8401
fax: $(865) 576-5728$
email: reports@adonis.osti.gov

\begin{abstract}
Available to the public from the National Technical Information Service, U.S. Department of Commerce, 5285 Port Royal Rd., Springfield, VA 22161 ph: (800) 553-6847 fax: $(703) 605-6900$

email: orders@ntis.fedworld.gov

online ordering: http://www.ntis.gov/ordering.htm
\end{abstract}

$\Delta$ This document was printed on recycled paper. 
PNNL-13692, Rev. 1

\section{Survey of Radiological and Chemical Contaminants in the Near-Shore Environment at the Hanford Site 300 Area}

G. W. Patton ${ }^{(a)}$

S. P. Van Verst ${ }^{(\mathrm{b})}$

B. L. Tiller ${ }^{(a)}$

E. J. Antonio ${ }^{(a)}$

T. M. Poston ${ }^{(a)}$

March 2003

Prepared for

the U.S. Department of Energy

under Contract DE-AC06-76RL01830

Pacific Northwest National Laboratory

Richland, Washington 99352

(a) Pacific Northwest National Laboratory
(b) Washington State Department of Health 


\section{Preface}

During August through October 2001, the Hanford Site Public Safety and Resource Protection Program and the Washington State Department of Health lead a multi-agency study to characterize the radiological and chemical conditions existing in the near-shore environment of the Hanford Site's 300 Area. The results from this study were published in September 2002 (PNNL-13692). Since PNNL-13692 was issued, several errors have been identified and some additional data have been requested. Therefore, several revisions have been made and this document is being reprinted as PNNL-13692, Rev. 1. ${ }^{1}$

The following changes are noted:

- The caption for Figure 3.2 was modified to identify map symbols.

- Figure 3.2 was modified to clearly show Location $7 / 9$ and $0.25 \mathrm{~m}$ (they were overlapped in the earlier figure). In addition, location names were changed from 7-9 to 7/9 and 9-11 to 9/11 to reflect the naming scheme used in the text.

- Figure 4.7 was incorrectly labeled "Total Uranium;" the figure had results for only uranium-238. A new figure was generated using the total uranium data.

- The caption for Figure 4.20 was changed from External Radiations-to External Radiation.

- In Table A.1, entries 7 (1.0) and 7 (0.5) were in the wrong order and Location 9 DR (025) was changed to 9 DR (0.25).

- In Table B.7 (page B.14), callout "c" was change to: (c) More than 1 sample; see Table 4.7.

- The misspelling of Corbicula in Table C.5 was corrected.

- Table C.5 was modified to include some missing biological media.

- Table C.6 was added. The table contains specific conductivity measurements for river water, crossriver transect, riverbank springs, and shallow groundwater samples.

\footnotetext{
${ }^{1}$ Because most changes for Rev. 1 were relatively minor, all individuals identified in the original distribution list who did not receive a copy of Rev. 1 were sent a cover letter describing the changes, a web address (http://sesp.gov/reports/reports.html) to view or print a PDF file of Rev. 1, and a copy of the Rev. 1 Preface. A limited distribution of Rev. 1 was made; however, hardcopies of PNNL-13692, Rev.1 are available upon request to Greg W. Patton at (509) 376-2027 (gw.patton@pnl.gov).
} 


\section{Summary}

Past operations at the Hanford Site have resulted in the release of radiological and chemical contaminants to the soil column, groundwater, and ultimately to the near-shore environment along the Columbia River shoreline. During August through October 2001, the Washington State Department of Health and Pacific Northwest National Laboratory conducted an assessment of the near-shore of the Columbia River at the 300 Area of the Hanford Site. The objective of this assessment was to identify any contamination present and determine if it could present a risk to humans and plant and animal life. The assessment characterized the radiological and chemical conditions existing in the near-shore environment of the Columbia River at the 300 Area by collecting water, biota, and sediment samples and measuring external radiation levels during a time when the effects of riverbank spring discharges and groundwater upwelling into the river was likely to be greatest.

An additional goal of this study was to present data that may be used by others to assess current radiological impacts to people utilizing the 300 Area shoreline. The contaminant concentrations, external radiation exposure rates, and calculated unit doses reported here may be used to estimate doses to individuals involved currently in specific activities at the vicinity of the 300 Area shoreline.

This study coincided with expected low river stage, which facilitated locating and sampling water from riverbank springs and other media along the shoreline. This study was able to track the progression of 300 Area groundwater contaminants from shallow groundwater to riverbank springs and ultimately to near-shore river water, sediment, and biota. An important component of this study consisted of split sampling, a process where a sample was collected, split into two separate samples, and each sample was analyzed by the participating organization. The results were then compared to assess the reliability of the data. The majority of the results for split samples showed excellent agreement between Washington State Department of Health and Pacific Northwest National Laboratory results.

The contaminants detected in the 300 Area by this study were similar to those found in previous studies. Gross alpha and uranium were the only contaminants that exceeded Washington State ambient surface water quality criteria in samples of shallow groundwater, riverbank spring water, and near-shore river water from the 300 Area. Other contaminants in the 300 Area near-shore water samples that were elevated compared to the background location (Vernita Bridge) were arsenic, barium, cesium-137, chromium, iodine-129, selenium, technetium-99, thallium, tritium, and zinc. However, they were all below water quality criteria.

Sediment samples from the 300 Area had elevated concentrations of strontium-90, cesium-137, and uranium compared to the background location near Vernita Bridge. The concentration of metals in the 300 Area sediment was similar or lower than for sediment from near Vernita Bridge.

Biota in the riparian community in the 300 Area had elevated concentrations of tritium, technetium-99, and uranium compared to the Vernita Bridge site. Mulberry samples generally had higher concentrations of radionuclides than sweet clover, and this may be related to the deeper rooting of the mulberry. Biota in the aquatic community in the 300 Area had elevated concentrations of technetium-99 and uranium 
compared to the Vernita Bridge location. Concentrations of arsenic, beryllium, chromium, selenium, and zinc also were elevated, compared to the Vernita background site, in some near-shore biota samples collected at the 300 Area. Individual clam samples were collected over a well-defined spatial range, and this allowed the aquatic habitat area in the 300 Area with elevated concentrations of chromium, selenium, and uranium to be estimated. An inspection of individual-level health revealed that the majority of biotic tissues from near the shore at both the 300 Area and the Vernita Bridge background location did not have significant lesions. However, the total number of samples was limited and this prevented detailed statistical comparisons.

The external radiation exposure rates at the 300 Area shoreline and the background site near Vernita Bridge were very similar. The data indicate that external exposure at the 300 Area shoreline all comes from background radiation. Therefore, there is no impact to people using the river or shoreline from external radiation originating at the 300 Area. A unit dose approach was used to estimate human doses from specific activities near the 300 Area near shore. The human doses from radionuclides estimated from likely current-use exposures, fishing and boating, are low and not expected to be harmful. In addition, human doses from chemicals are also low and not expected to be harmful to people engaged in fishing or boating along the 300 Area shoreline.

Overall, this study was able to monitor the progression of contaminants in 300 Area groundwater from shallow groundwater, to riverbank springs, and ultimately to river water, sediment, and biota. Discharges of riverbank spring water appear to be the major source of 300 Area groundwater contaminants entering the river during low river flow conditions. There was evidence for groundwater upwelling into the near-shore river water at locations where no flowing riverbank springs were observed; however, river water samples from these locations had lower concentrations of contaminants than the locations with active riverbank springs. Clam samples were shown to be effective for estimating the aquatic habitat in the 300 Area with elevated concentrations of chromium, selenium, and uranium. Similar spatial profiles were observed for uranium concentrations in near-shore river water (at low river stage) and uranium in soft tissues of clams. 


\section{Acknowledgments}

The authors wish to acknowledge Lynn Albin, Evan Arntzen, Lynn Bisping, Tom Cooper, Al Danielson, Brad Fritz, Mike Goldstein, Dibakar Goswami, Bill Hanf, Mitch Hawkes, Dick Jaquish, Eddie Radford, Jerry Yokel, and Rhett Zufelt for their help in collecting samples. Jerry Heidel of Oregon State University performed the histopathological assays. Dibakar Goswami and Mike Goldstein provided valuable suggestions for the sample design. Lynn Albin provide valuable assistance interfacing with the Washington State Public Health Laboratory. Launa Morasch provided editorial review and Kathy Neiderhiser provided text processing. 


\section{Contents}

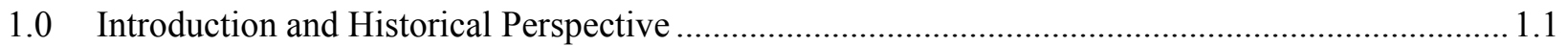

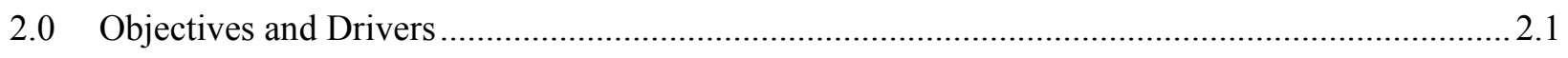

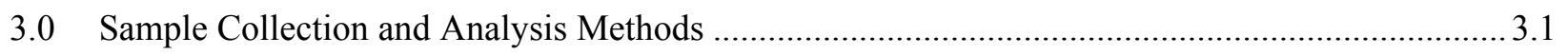

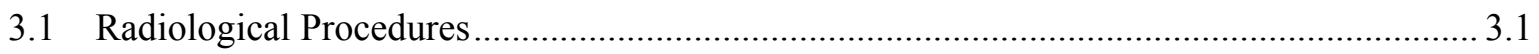

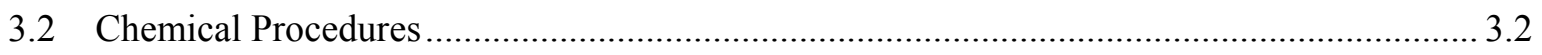

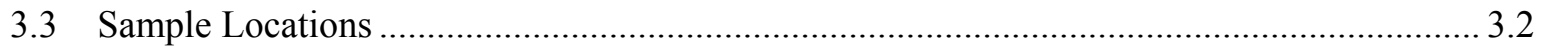

3.4 Water 3.2

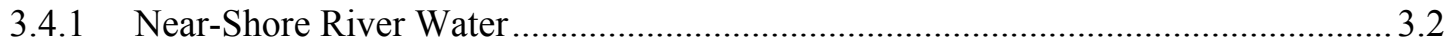

3.4.2 Cross-River Transects and Additional Near-Shore Water ......................................... 3.5

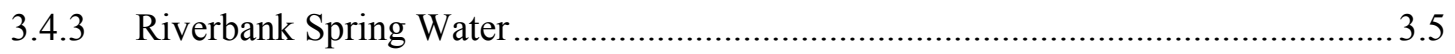

3.4.4 Drive Point Water (Shallow Groundwater) .............................................................. 3.5

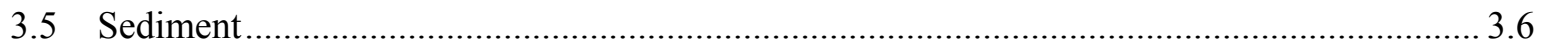

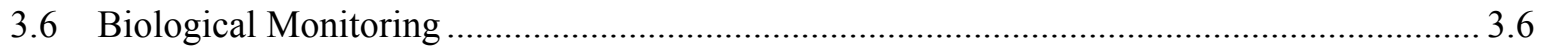

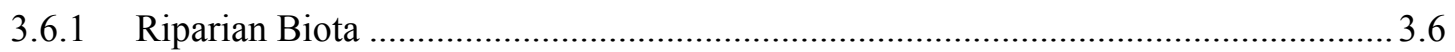

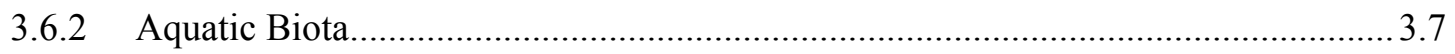

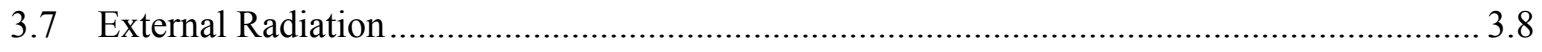

3.8 Quality Assurance and Quality Control …............................................................... 3.9

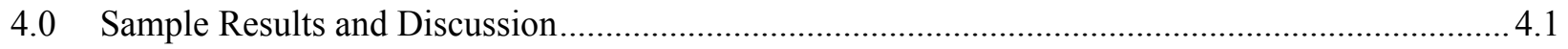

4.1 Water 4.1

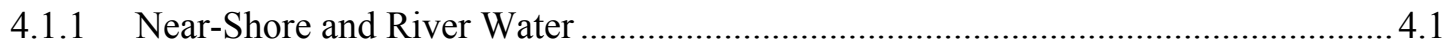

4.1.2 Cross-River Transects and Additional Near-Shore River Water................................ 4.4

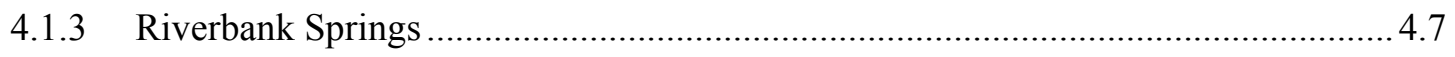

4.1.4 Shallow Groundwater Drive Points.................................................................... 4.11

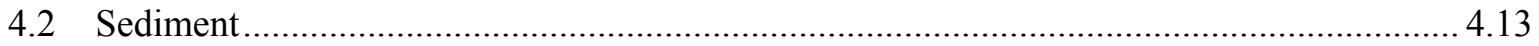

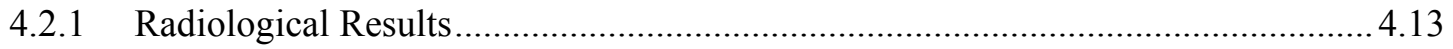


4.2.2 Comparison to 1992 Near-Shore Report ............................................................... 4.14

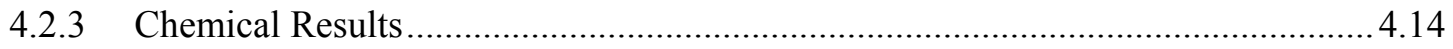

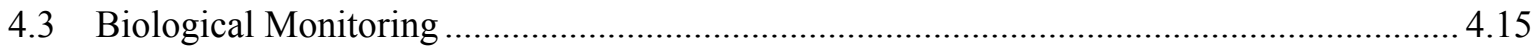

4.3.1 Riparian and Aquatic Community Surveillance.................................................... 4.16

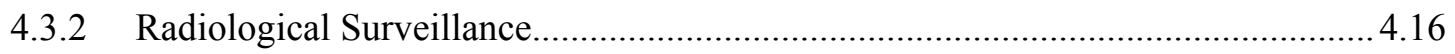

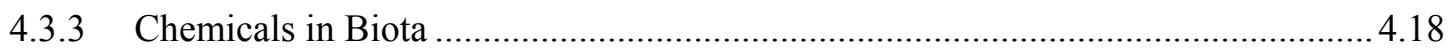

4.3.4 Inspection of Individual-Level Health of Selected Biota Types ............................ 4.27

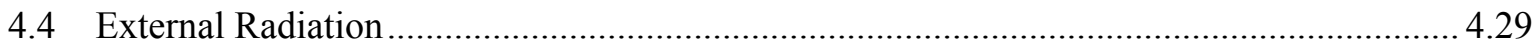

4.5 Comparison of Results from Split Samples (analyzed by both Washington State Department

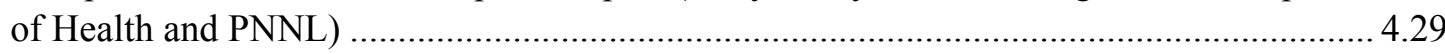

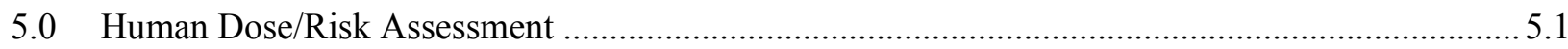

5.1 Methods to Assess Current Impact to Human Health from Radionuclides........................... 5.1

5.2 Application to Specific Radionuclide Exposure Scenarios .............................................. 5.3

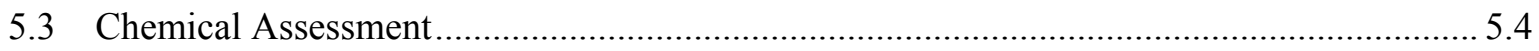

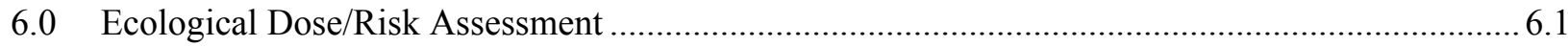

6.1 Methods for Radiological Assessment of Biological Impact ............................................. 6.1

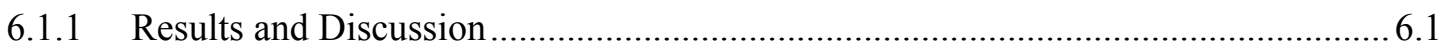

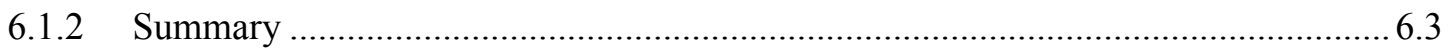

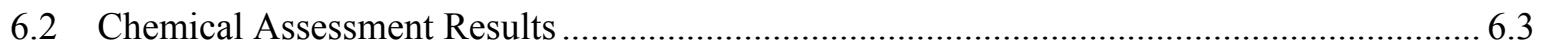

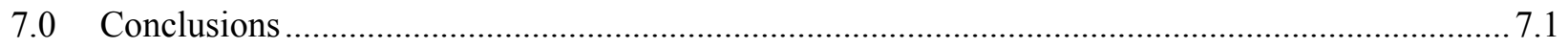

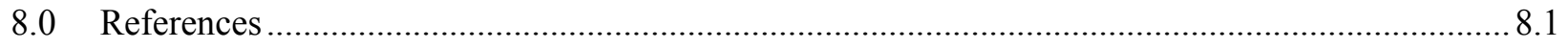

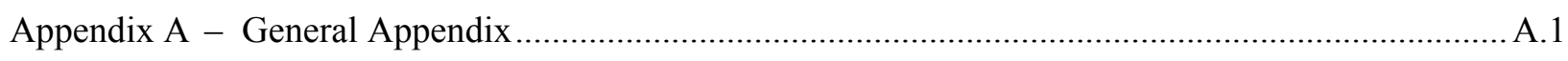

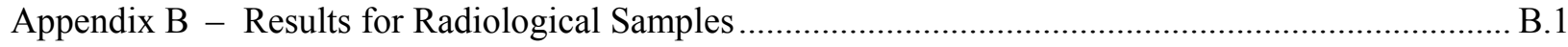

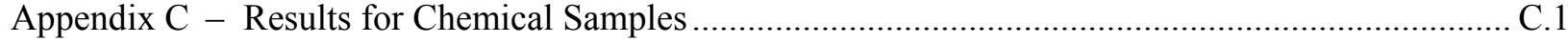

Appendix D - Results for Split Radiological Samples ............................................................... D. 1

Appendix E - BDAC Screening and Species-Specific Dose Calculations........................................... E.1 


\section{Figures}

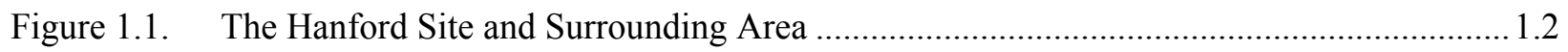

Figure 3.1. 300 Area Near-Shore Sampling Locations …............................................................ 3.3

Figure 3.2. $\quad 300$ Area Water and Biota Sampling Transects and Associated River Depths..................... 3.4

Figure 4.1. Specific Conductivity Measurements for 300 Area and Vernita Bridge Near-Shore River Water and Riverbank Spring Samples ................................................................. 4.2

Figure 4.2. Tritium Concentrations for 300 Area and Vernita Bridge Near-Shore River Water and Riverbank Spring Samples

Figure 4.3. Total Uranium Concentrations for 300 Area and Vernita Bridge Near-Shore River Water and Riverbank Spring Samples

Figure 4.4. Selected Metal Concentrations for 300 Area Near-Shore and Vernita Bridge River Filtered Water Samples.

Figure 4.5. Tritium Concentrations in Water Samples from Cross-River Transects and Near-Shore Locations

Figure 4.6. Strontium-90 Concentrations in Water Samples from Cross-River Transects and Near-Shore Locations

Figure 4.7. Total Uranium Concentrations in Water Samples from Cross-River Transects and Near-Shore Locations

Figure 4.8. Nitrate Concentrations in Water Samples from Cross-River Transects and Near-Shore Locations

Figure 4.9. Isotopic Abundance of Uranium (U-234, U-235, and U-236) in River Water from Vernita Bridge and Riverbank Spring Water from the 300 Area (ICP-MS data)

Figure 4.10. Tritium, Total Uranium, and Specific Conductivity for 1992 to 2001 Riverbank Spring Water at Location 7

Figure 4.11. Selected Metal Concentrations in Filtered Water Samples from 300 Area Riverbank Springs and River Water at Vernita Bridge

Figure 4.12. Specific Conductivity Measurements for Water Samples Collected from 300 Area Shallow Groundwater (drive point samples). 
Figure 4.13. Total Uranium Concentrations for Water Samples Collected from 300 Area Shallow Groundwater (drive point samples).

Figure 4.14. Tritium Concentrations for Water Samples Collected from 300 Area Shallow Groundwater (drive point samples).

Figure 4.15. Chromium in Soft Tissues of Asian Clams..................................................................2 4.23

Figure 4.16. Selenium in Soft Tissues of Asian Clams .................................................................. 4.25

Figure 4.17. Uranium Concentrations in Selected Biota ...............................................................26

Figure 4.18. Uranium in Soft Tissues of Asian Clams .......................................................................27

Figure 4.19. External Radiation Measurements at the 300 Area Shoreline........................................ 4.30

Figure 4.20. External Radiation Measurements near Vernita Bridge............................................... 4.31

\section{Tables}

Table 4.1. Summary of Biotic Samples

Table 4.2. Concentrations of Technetium-99 in Selected Biota $(\mu \mathrm{g} / \mathrm{g}$ dry wt., minimum detection $<0.15 \mathrm{pCi} / \mathrm{g}$ dry wt.)

Table 4.3. Concentrations of Arsenic in Selected Biota ( $\mu \mathrm{g} / \mathrm{g}$ dry wt., minimum detection $<0.1 \mu \mathrm{g} / \mathrm{g}$ dry wt.)

Table 4.4. Concentrations of Beryllium in Selected Biota ( $\mu \mathrm{g} / \mathrm{g}$ dry wt., minimum detection $<0.1 \mu \mathrm{g} / \mathrm{g}$ dry wt.)

Table 4.5. Concentrations of Chromium in Selected Biota ( $\mu \mathrm{g} / \mathrm{g}$ dry wt., minimum detection $<0.1 \mu \mathrm{g} / \mathrm{g}$ dry wt.)

Table 4.6. Concentrations of Selenium in Selected Biota ( $\mu \mathrm{g} / \mathrm{g}$ dry wt., minimum detection $<0.2$ to $0.6 \mu \mathrm{g} / \mathrm{g}$ dry wt.)

Table 4.7. Concentrations of Uranium in Selected Biota $(\mu \mathrm{g} / \mathrm{g}$ dry wt., minimum detection $<0.1 \mu \mathrm{g} / \mathrm{g}$ dry wt.) 
Table 4.8. Concentrations of Zinc in Selected Biota $(\mu \mathrm{g} / \mathrm{g}$ dry wt., minimum detection $<0.1 \mu \mathrm{g} / \mathrm{g}$ dry wt.)

Table 4.9. Distances Between Shoreline Locations and Perpendicular Distances from the Shoreline for 300 Area Biota Sample Transects

Table 4.10. Normal Statistics for Reduced Exposure Rate Datasets Collected near Vernita Bridge and along the 300 Area Shoreline

Table 5.1. Unit Doses for External Radiation and Consumption Pathways for the 300 Area Near Shore

Table 6.1. Initial 300 Area Shoreline Study Screening Assessment based on the Biota Dose Calculator Summation of Partial Fractions 6.2

Table 6.2. Estimated Internal and External Dose Rates (rad/day) by Location and Biota..................6.3 


\subsection{Introduction and Historical Perspective}

The 300 Area of the Hanford Site (Figure 1.1) is located just north of the city of Richland, Washington. The Hanford Site borders the Columbia River and covers 1,517 square kilometers (586 square miles). From the 1940s, most of the research and development for the Hanford Site was conducted in the 300 Area. In addition, the 300 Area was used for the production of nuclear fuel elements for the Hanford reactors. The fuel elements were produced by extruding metallic uranium into pipe-like cylinders and encapsulating them with aluminum or zirconium cladding. This process resulted in substantial amounts of uranium and heavy metals in the 300 Area liquid waste streams. Initially, the liquid waste from the research facility and fuel production was routed to waste ponds in the northern part of the 300 Area located near the Columbia River shoreline. In 1975, the liquid waste was sent to process trenches in the northern part of the 300 Area with discharges ending in 1995. At the present time, all liquid waste from the 300 Area is treated at the 300 Area Treated Effluent Disposal Facility and released to the Columbia River under the requirements of a National Pollutant Discharge Elimination System permit.

The 300 Area is no longer used for nuclear fuel production and large portions are currently undergoing environmental cleanup. The groundwater under the 300 Area has contaminants from both 300 Area derived materials (primarily uranium) and from the contaminated groundwater plumes from the Hanford Site's 200 Areas plateau (primarily tritium). The 300 Area is one of four Comprehensive Environmental Response, Compensation, and Liability Act of 1980 (CERCLA) National Priorities List sites at Hanford. CERCLA operable units are groupings of waste sites based on geographic area and common waste sources. The 300 Area has two contaminated soil operable units (300-FF-1 and 300-FF-2) and a contaminated groundwater operable unit (300-FF-5) (DOE/RL 1993; DOE/RL 1995; DOE/RL 1997; DOE/RL 2000a). As the cleanup has progressed, there has been extensive evacuation and removal of contaminants with an industrial reuse scenario as the basis for evaluating the adequacy of cleanup. However, residual soil concentrations must also protect ecological receptors, groundwater, and Columbia River water. The remedy for contaminated 300 Area groundwater is monitored natural attenuation with the goal of restoring the aquifer to drinking water standards. An Operation and Maintenance Plan has been developed for the 300-FF-5 Operable Unit that discusses the role of enhanced biological monitoring as a means of evaluating the adequacy of the cleanup standards (DOE/RL 2002).

Contaminants that originate at Hanford can be detected in water from riverbank springs entering the Columbia River along the 300 Area shoreline (Dirkes 1990; Friant and Hulstrom 1993; Poston et al. 2001). The city of Richland withdraws Columbia River water for its water supply $\sim 8$ kilometers downstream of the 300 Area. Richland is the nearest community downstream of Hanford using the Columbia River as its drinking water source. Environmental surveillance of the Columbia River at the city of Richland water intake has measured small amounts of radioactive materials (primarily tritium and iodine-129); however, the amounts have always been far below federal and state limits and the water in the Columbia River continues to be designated Class A (Excellent) by the State of Washington (WAC 173-201A; Dirkes 1993; Dirkes 1994; Poston et al. 2001). 


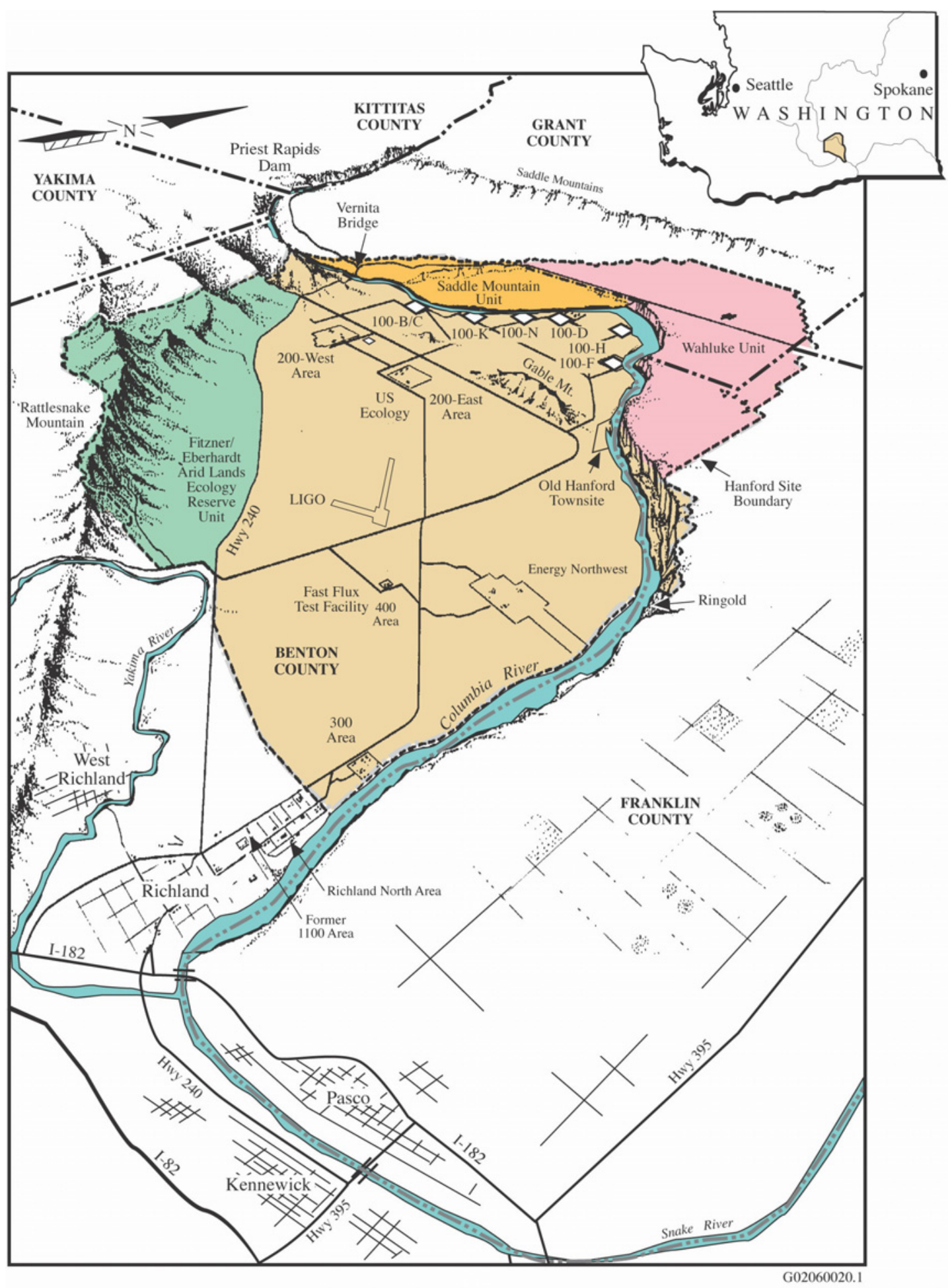

Figure 1.1. The Hanford Site and Surrounding Area 
This document describes a contaminant characterization and a biological and human dose/risk assessment study for the near-shore of the Columbia River at the 300 Area of the U.S. Department of Energy's (DOE's) Hanford Site. The study was conducted in August to October 2001 to coincide with expected low river stage and, thus, represented a likely worst-case scenario with respect to contaminated groundwater discharging to the Columbia River. The low river stage facilitated locating and sampling riverbank spring water and other media along the Columbia River shoreline. A number of contaminants are present in groundwater at the 300 Area and the near-shore environment can be exposed through riverbank springs and groundwater upwelling. Therefore, the sampling locations selected for this study were centered near historic riverbank spring discharges and the contaminants of concern were primarily known groundwater contaminants (i.e., anions, metals, radionuclides, and volatile organics); however, when possible, screening assays (e.g., gross alpha, gross beta, and gamma-emitting radionuclides) and expanded suites of analytes (e.g., anions, metals, and volatile organics) were used to check for other possible contaminants.

Section 2.0 presents the objectives and regulatory drivers for this study. Section 3.0 provides a description of the sample collection and analysis processes. Analytical results and discussion for both radiological and chemical samples are summarized in Section 4.0 and tabulated in the Appendixes. Sections 5.0 and 6.0 present human and ecological dose/risk assessments based upon the analytical results. Finally, the conclusions of this study are presented in Section 7.0. 


\subsection{Objectives and Drivers}

The objective of this study was to characterize the radiological and chemical conditions existing in the near-shore environment of the Columbia River at the 300 Area by collecting water, biota, and sediment samples and measuring external radiation levels during a time period when the effects of riverbank spring discharges and groundwater upwelling into the river was likely to be greatest. Additionally, this study assessed the potential impact on resident ecological receptors and people that may visit this location.

Environmental surveillance of the Hanford Site and the surrounding region is conducted to demonstrate compliance with environmental regulations, confirm adherence to DOE environmental protection policies, support DOE environmental management decisions, and provide information to the public. The Hanford Site Public Safety and Resource Protection Program (PSRPP) conducted this study through the Surface Environmental Surveillance Project (SESP) under DOE Orders 5400.1 and 5400.5.

The Washington State Department of Health conducted this study under their legislative mandate.

This study was conducted in a CERCLA operable unit. Although this study was not required by the U.S. Environmental Protection Agency (EPA) or Washington State Department of Ecology as part of the ongoing CERCLA and Resource Conservation and Recovery Act of 1976 (RCRA) monitoring, it provides information for designing future monitoring efforts. The Operation and Maintenance Plan for the 300-FF-5 Operable Unit (DOE/RL 2002) contains groundwater and shoreline monitoring requirements pursuant to the 1996 CERCLA Record of Decision and the 300 Area Process Trench Groundwater Monitoring Plan (Lindberg and Chou 2001) contains groundwater monitoring requirements pursuant to the RCRA closure plan for the 300 Area process trench. Additional drivers for 300 Area CERCLA monitoring include the records of decision for 300-FF-1, 300-FF-2, and 300-FF-5. The records of decision are legally binding documents that define cleanup and allowable residual contamination. Supporting documents that address monitoring in the 300 Area CERCLA operable units include: remedial design/ remedial action work plans, sampling and analysis plans, 5-year review reports, and operations and maintenance plans (DOE/RL 1993; DOE/RL 1995; DOE/RL 1997; DOE/RL 2000a; DOE/RL 2002). 


\subsection{Sample Collection and Analysis Methods}

This study required the collection of samples of shallow groundwater beneath the riverbed, riverbank spring water, river water, sediment, aquatic biota, riparian biota, and measured external radiation levels at the 300 Area and a control location near Vernita Bridge that is upriver from the Hanford production areas ( 68 kilometers) upriver from the 300 Area).

Where applicable, samples were collected according to the Surface Environmental Surveillance Procedures Manual (PNL-MA-580) or using the methods described in Survey of Radiological Contaminants in the Near-Shore Environment at the Hanford Site 100-N Reactor Area (Van Verst et al. 1998). Non-routine sampling methods were documented in field record notebooks.

Field record forms and sample labels were prepared for all sediment and water samples. Biota samples were logged as they were collected, and chain-of-custody forms were prepared post-collection. Chain-of-custody forms were not prepared prior to biota sampling because sufficient sample material may not have been available at all study sites.

It was not possible to collect all samples on the same day because of the large study area, numerous target biota, and the large amount of samples required. Water sampling dates (all in 2001) and daily (24-hour) average flow conditions for the Columbia River measured at Priest Rapids Dam (Poston et al. 2002) are discussed below. The 300 Area and Vernita Bridge river water and 300 Area riverbank spring water was collected on August 27 at 2,680 cubic meters (95,700 cubic feet) per second river flow. Vernita Bridge cross-river water samples were collected on September 7 at 1,220 cubic meters (43,600 cubic feet) per second river flow. The 300 Area cross-river water samples were collected on September 13 at 2,220 cubic meters (79,300 cubic feet) per second river flow. Shallow groundwater samples from drive points were collected on September 17 at 1,520 cubic meters (54,300 cubic feet) per second river flow and on September 18 at 1,740 cubic meters (62,100 cubic feet) per second river flow. The August 27 water samples were collected during a period where river stage increased during the sampling day; however, the 300 Area water samples were all collected during a time period when riverbank springs were actively flowing and the specific conductivity values for the riverbank springs indicated a high percentage of groundwater was present. Specific conductivity values for riverbank spring water were similar for samples collected on August 27, September 17, and September 18 despite a 1.8 -fold variation in daily average flow conditions. Sediment, riparian and terrestrial vegetation, clams, aquatic vegetation, periphyton, and external radiation measurements were collected on August 27 and 28, 2001. Invertebrates, mice, fish, and crayfish were collected over the period August 26 to September 11, 2001.

\subsection{Radiological Procedures}

The analytical methods used by SESP for radiological analysis of water, sediment, and biota samples are described in detail in DOE/RL 2000b and include methods for gross alpha, gross beta, gammaemitting radionuclides, tritium, strontium-90, technetium-99, iodine-129, and uranium isotopes. Thorium samples were analyzed by alpha spectrometry following radiochemical processing. In addition, uranium 
isotopes (including uranium-236) were also analyzed using the methods described in PNL-SC-01, Inductively Coupled Plasma Mass Spectrometric (ICP-MS) Analysis.

The analytical methods used by the Washington State Department of Health for radiochemical analysis are described in the Washington State W.R. Giedt Public Health Laboratories' 2001 Radiation Chemistry Procedure Manual.

\subsection{Chemical Procedures}

The analytical methods for chemical analysis for water, sediment, and biota are described in detail in DOE/RL 2000b and include methods for anions, metals, and volatile organic compounds.

\subsection{Sample Locations}

Sampling areas included an upriver control site (see Figure 1.1, Benton County side of the river near the Vernita Bridge) and the 300 Area shoreline (see Figure 3.1 and Figure 3.2) in the vicinity of four riverbank springs reported from previous studies (Friant and Hulstrom 1993). The three upriver riverbank spring areas encompass the uranium and tritium groundwater plumes (Location 7 [SESP Spring 42.2], Location 9 [SESP Spring 42.2 DR], and Location 11). The downriver riverbank spring site is located downriver of the 300 Area near an unimproved public boat launch (Location 14). However, during the sample collection period, only the riverbank springs at Locations 7 and 9 were actively discharging; the riverbank springs at Locations 11 and 14 were dormant (i.e., not actively flowing).

In addition to the major riverbank spring areas (Locations 7, 9, 11, and 14) described above, samples were also collected at locations $\sim 100$ meters downriver from Locations 7, 9, and 11 (Locations 7 DR, $9 \mathrm{DR}$, and $11 \mathrm{DR}$ ) and at locations between the major riverbank spring areas (midpoint between Locations 7 and 9 and the midpoint between Locations 9 and 11 [Locations 7/9 and 9/11]). Global positioning system (GPS) coordinates were recorded for sampling locations and are given in Appendix A, Table A.1.

\subsection{Water}

Water samples collected for this study included near-shore river water, cross-river transects, riverbank spring water, and shallow groundwater collected from drive point wells.

\subsubsection{Near-Shore River Water}

Near-shore river water samples were collected from near the river bottom by using a peristaltic pump and Tygon ${ }^{\circledR}$ tubing with the sample inlet positioned 6 centimeters above the river bottom. The samples were collected at Locations 7, 9, 11, and 14; 7 DR, 9 DR, and 11 DR; and 7/9 and 9/11 as described in Section 3.3. All samples were unfiltered water; except samples for metals analysis where both unfiltered and filtered samples were collected $(0.45 \mu \mathrm{m}$ Geotech high volume filter). At each location, a set of four river water samples were collected, with samples taken at the immediate shoreline (a depth of 0.25 meter), and offshore where the river depth was 0.5 meter, 1 meter, and 1.5 meters. This allowed sampling to occur over the depth ranges where an adult human could reasonably wade. The river water 
samples are identified by their location and river depth. For example, 7 ( 0.25 meter) refers to the sample from Location 7 at a depth of 0.25 meter. Specific conductivity (microsiemens $/ \mathrm{cm}=\mu \mathrm{S} / \mathrm{cm}$ ), $\mathrm{pH}$, and temperature measurements were recorded for each water sample.

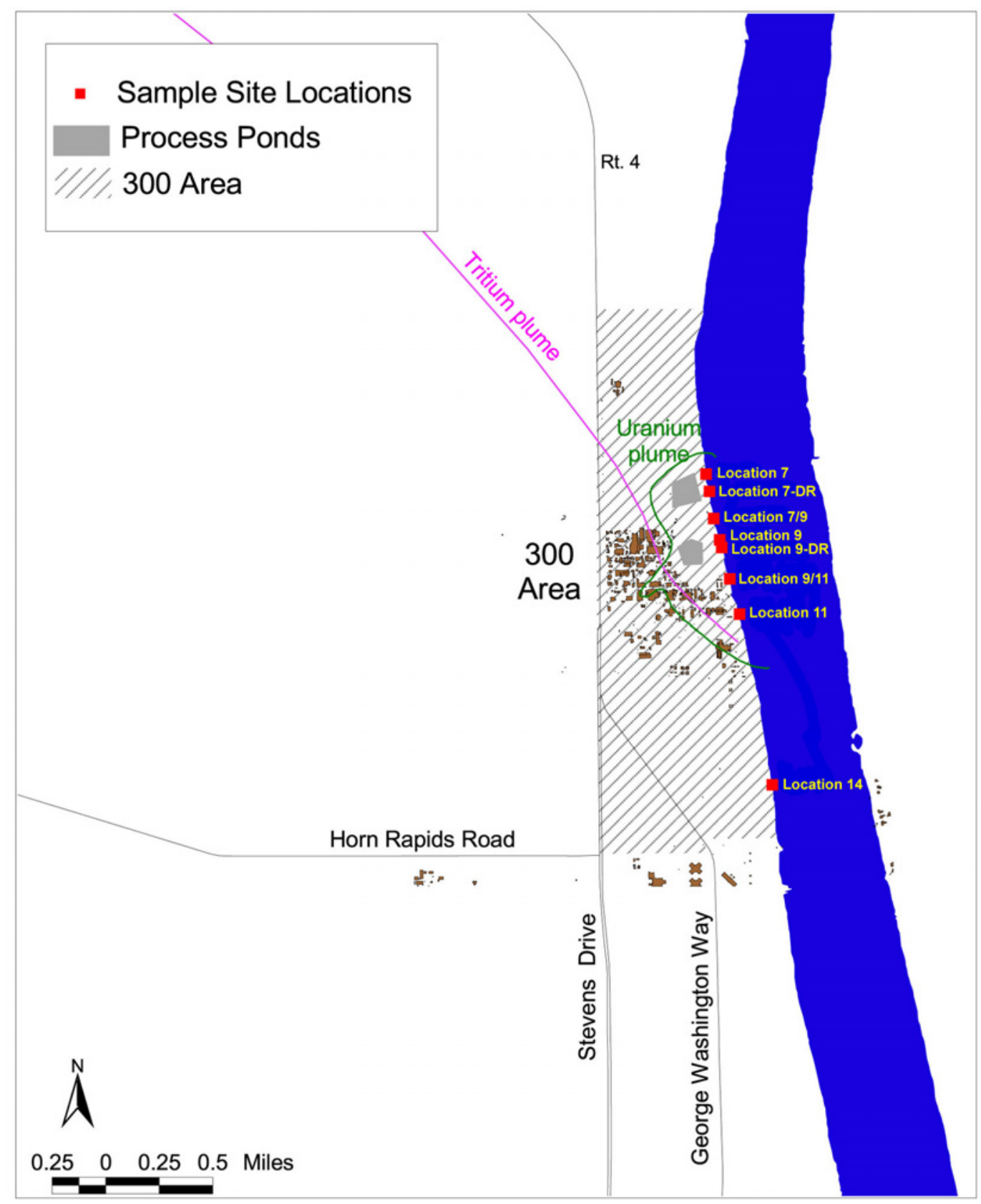

Figure 3.1. $\quad 300$ Area Near-Shore Sampling Locations 


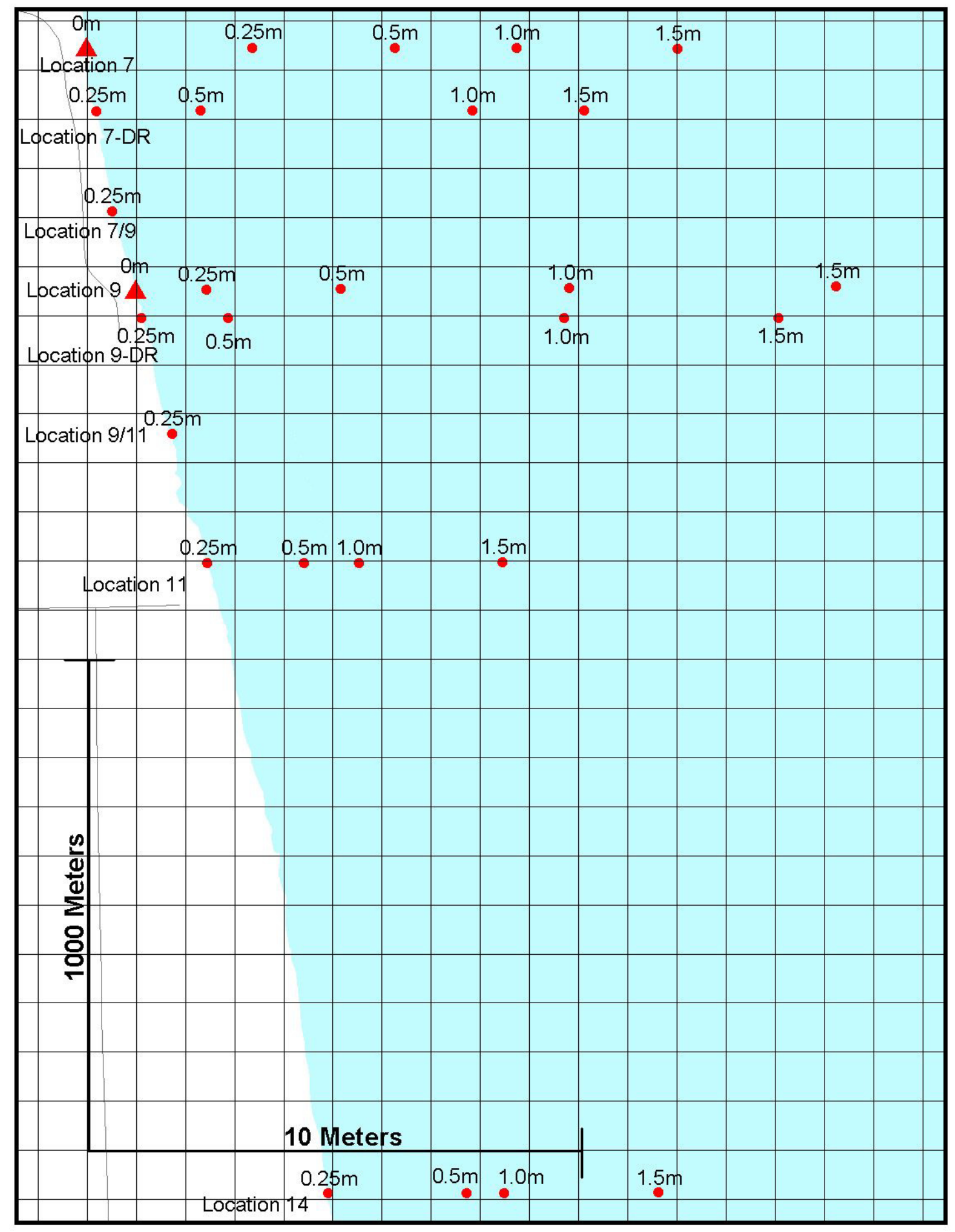

Figure 3.2. $\quad 300$ Area Water and Biota Sampling Transects and Associated River Depths (Triangles indicate riverbank springs and circles indicate river water and aquatic biota sampling points.) 


\subsubsection{Cross-River Transects and Additional Near-Shore Water}

Cross-river transects and additional near-shore water samples were collected at the 300 Area southern boundary and at a background location near Vernita Bridge. The cross-river water samples were collected at mid-depth according to the Surface Environmental Surveillance Procedures Manual (PNLMA-580). Transect stations (sampling points) are determined by dividing the cross-river distance into 10 sections. The station closest to the Benton County shoreline is Station 1 and the station closest to the Franklin County shoreline is Station 10 (e.g., mid-river points would be at Stations 5 and 6). Samples are not always collected at each station (e.g., for this study, Station 4, 6, 8, and 9 were not sampled). These samples were scheduled as part of the routine Hanford Site SESP and Washington State Department of Health sampling effort (Bisping 2001). Some near-shore water sampling locations are identified using Hanford river markers (HRM). These markers are a set of signposts on the Hanford shore that are roughly 1.6 kilometers apart. Vernita Bridge is HRM \#0 and Ferry Street in Richland is HRM \#46. Samples collected between markers are assigned a decimal number (e.g., HRM \#12.5 is halfway between HRM \#12 and HRM \#13). Specific conductivity, $\mathrm{pH}$, and temperature measurements were conducted for each water sample.

\subsubsection{Riverbank Spring Water}

Samples of riverbank spring water were collected at Locations 7, 9, and Vernita Bridge using either a hand pump or a peristaltic pump. All samples were unfiltered water, except samples for metals analysis where both unfiltered and filtered samples were collected $(0.45 \mu \mathrm{m}$ Geotech high volume filter). Specific conductivity, $\mathrm{pH}$, and temperature measurements were made for each water sample.

\subsubsection{Drive Point Water (Shallow Groundwater)}

Drive point (shallow groundwater) water samples were collected using a peristaltic pump to pull water from polyethylene tubing installed into the shallow aquifer beneath the river bottom. An array of drive points was installed at riverbank spring Locations 7 and 9 (riverbank springs that traditionally have the highest uranium concentrations). All samples were unfiltered water. Specific conductivity measurements were made for each water sample. Because installing and collecting water from the drive points required a substantial time commitment, these samples were collected during a separate sampling effort in mid-September 2001.

Drive points were installed at two sites at Location 7 and three sites at Location 9, with the intake screens of the sampling tubes installed at three depths ( $\sim 0.6$ to $0.76,1.2$ to 1.4 , and 1.7 to 1.8 meters below the river bed). The drive points are identified by location number, relative distance from the shore into the Columbia River, and depth (e.g., the name DP 7-1 [0.76 meter] stands for a drive point installed at Location 7, first point in a line from the shore, and an intake screen depth of 0.76 meter). However, because of the high variability of the shallow aquifer, it was not possible to collect sufficient water volumes from all drive point locations.

On September 17, 2001, samples were collected from drive points at Location 9. Three drive point sites were installed in a line directly out into the river from the spring, located 1, 8, and 14.3 meters (DP 9-1, 9-2, and 9-3, respectively) from the main spring discharge. Water was successfully collected from DP 9-1 (0.6 meter), DP 9-1 (1.2 meters), DP 9-2 (0.6 meter), DP 9-2 (1.4 meters), and DP 9-3 (1.7 meters). 
On September 18, 2001, samples were collected from drive points at Location 7. Two drive point sites were installed in a line directly out into the river from the spring with points located 4.6 and 9.4 meters (DP 7-1 and 7-2, respectively) from the main spring discharge. Water was successfully collected from DP 7-1 (0.76 meter), DP 7-1 (1.2 meters), DP 7-1 (1.8 meters), DP 7-2 (0.61 meter), and DP 7-2 (1.3 meters).

\subsection{Sediment}

Sediment samples at the riverbank spring locations (Locations 7, 9, 11, and 14) and at the background site were collected using nylon ladles. Samples were placed into plastic bags.

\subsection{Biological Monitoring}

Biota samples were collected using a variety of techniques. Sampling took place over several days to allow for adequate sample mass to be collected. Small mammal collection efforts continued for one week. All tissue-specific samples were prepared for submission to laboratories within 24 hours of the field collection. Sample collectors wore latex gloves prior to sample collections at each site. Gloved hands and tools were washed with Alconox ${ }^{\circledR}$ solution and rinsed thoroughly with deionized water between each sampling event. Processed samples were rinsed with deionized water, placed directly into the sample containers, sealed with custody tape, labeled, and stored for shipment to the analytical laboratories. Samples submitted for analyses of metal concentrations were stored in certified pre-cleaned 200-milliliter amber glass jars or acetone-washed 1-milliliter plastic vials. Samples submitted for radiological analyses were placed in plastic bags. Samples submitted for histological analyses were fixed in phosphate-buffered $2 \%$ formalin using a 1:10 ratio of sample volume to formalin volume.

Biota samples with sufficient sample mass (100 grams or more) to detect low levels of radioactivity were analyzed for gamma-emitting isotopes (primarily cobalt-60 and cesium-137), strontium-90, and technetium-99. For each biota, a composite sample from each site was submitted to the analytical laboratory.

All biota samples were analyzed for antimony, arsenic, beryllium, cadmium, chromium, copper, lead, mercury, nickel, selenium, silver, thorium, uranium, and zinc using inductively coupled plasma-mass spectroscopy (ICP-MS). Results generated from the ICP/MS analyses (including uranium and thorium) were reported in micrograms per gram dry weight and were used to compare concentrations of these contaminants in the biota sampled at each location. The ICP-MS method only required a small sample mass ( $\sim 0.4$ grams) for low-level detection. The small sample size allowed the measurement of contaminants in small-bodied organisms and, in some cases, allowed analysis of individual organs known to accumulate the contaminants of concern. This also allowed the collection of multiple samples within one location to better define the spatial extent where organisms may have accumulated Hanford-derived contamination.

\subsubsection{Riparian Biota}

Mice. House mice (Mus musculus) were chosen to represent the small mammal species because they are highly dependent on the riparian habitat for water and succulent foods. Animals were collected using 
pre-cleaned Sherman live traps baited with peanut butter. House mice were captured and placed individually in pre-cleaned glass containers, labeled, and stored in ice-filled coolers until samples were processed. Whole body weight, length, sex, age, reproductive status, and target organ weights $( \pm 0.01$ gram $)$ of each individual specimen were measured and recorded. Ten traps were set at each site and were checked each morning for a total of 4 nights, comprising 40 trap nights at each site. Non-target species (deer mice and pocket mice) were encountered at Locations 7 and 11 and all were immediately released unharmed. Nearly 160 trap nights were conducted at the Vernita Site; however, no small mammals were captured.

The liver and left kidney were removed from each mouse, weighed, and split for individual analyses of metals and histological interpretation of condition. A sample of skin and hair also was obtained from each mouse and analyzed for 16 metals. In addition, samples of lungs, gonads (if present), kidneys, and the skeletal system were placed in $2 \%$ phosphate-buffered formalin and submitted to the University of Oregon animal diagnostics laboratory for histological examination of animal/organ condition. Individual organisms from each site were combined as one composite sample, consisting of the remaining unsampled tissues (carcass, gut, and intestines). The composite samples were submitted for radiological analyses of gamma-emitting radionuclides, strontium-90, and technetium-99.

Invertebrates. Adult mayflies (Ephemeroptea sp.) and darkling beetles (Eleoides $s p$.) samples were hand picked at each location within 50 meters (164 feet) of each sampling location. Adult mayfly samples were rinsed in deionized water because they were obtained along the water's edge and were covered with dirt particles. All rinsed samples were placed directly into the individual sample containers, labeled, and stored for shipment to the analytical laboratories.

Riparian Vegetation. Riparian vegetation samples (new growth only) of the perennial plant white sweet clover (Melalotus alba) and leaves and stems from mulberry trees (Morus alba) were cut with stainless steel scissors at each of the designated sampling locations and placed in glass jars for metals analyses or plastic bags for the radiological analyses.

\subsubsection{Aquatic Biota}

Sculpin and Crayfish. Prickly sculpin (Cottus asper) and crayfish (Astacus sp.) were collected along the near-shore $(<0.5$ meter deep) and within 10 meters of the sampling locations. Sculpin were collected with the use of a Smith-Root Type IV backpack electrofisher and crayfish were hand-netted consistent with the conditions of Washington State and National Marine Fisheries Service permits. ${ }^{1}$ Samples were placed in cleaned glass containers, labeled, and stored in ice-filled coolers until the samples were processed. Sculpin were not observed within 100 meters upstream or downstream of Location 9. Cobble substrate at Location 9 was embedded in clay soils, minimizing the substrate available for sculpin and crayfish to hide underneath. In addition, Location 9 generally had the highest water velocities of all sites sampled. Whole body weight, length, sex, and target organ weight of each individual specimen were measured and recorded $( \pm 0.01$ gram). Carapace length (rostrum to end of thoracic segment) was measured as an index of crayfish size as opposed to whole-body length measured for sculpin samples collected.

\footnotetext{
${ }^{1}$ WA01-040, consultation with B. Tiller, Pacific Northwest National Laboratory, on July 11, 2000.
} 
The hepatopancreas was removed from each crayfish, weighed, and split for individual analyses of metals and histological interpretations of condition. The liver was removed from each sculpin, weighed, and split for individual analyses of metals and histological interpretations of condition. Since sculpin kidney mass was generally not large enough to analyze selected metal levels, a portion of the skeletal system was removed and cleaned of muscle tissue and submitted for analyses of total uranium. In addition, samples of gills, gonads, kidneys (sculpin only), and the skeletal system were placed in 2\% phosphate-buffered formalin and submitted to the University of Oregon's animal diagnostics laboratory for histological examination of animal/organ condition. For both species, organisms from each site were combined into one composite sample, consisting of the remaining tissues (carcass, gut, and intestines), and submitted for radiological analyses of gamma-emitting radionuclides, strontium-90, and technetium-99.

Clams. Two to five Asian clams (Corbicula sp.) were collected at each spring and along an axis perpendicular to the shoreline, systematically at depths of $0.25,0.5,1.0$, and 1.5 meters. Organisms living in the riverbank springs were collected when present. Clam collection was conducted concurrently with water sampling to measure and compare the levels of contaminants in the clam with water concentrations measured near the bottom of the river. Pairing the water and clam results allowed an examination of the utility of using clams to detect the presence and depict the spatial extent of Hanford Site contaminants in the river environment. Clams were collected on August 27, 2001 at all four spring sites, at two downriver locations below Locations 7 and 9 (7 DR and 9 DR), and at the reference site above Vernita Bridge. At Locations 7 and 9, clams were actually removed from the point where riverbank spring water entered the river ( 0 meter depth). Clams were generally abundant at all sites sampled, except above Vernita Bridge where aquatic vegetation obstructed visibility beyond water depths of 0.5 meter. In this case, three sub-samples at a depth of 0.5 meter were collected in addition to sub-samples obtained at depths of 0.0 and 0.25 meter. Each sample consisted of two to five individual organisms. Soft tissue was separated from shell tissue and submitted separately for metals analyses (including total uranium).

Aquatic Vegetation. Macrophytic vegetation (submerged aquatic vegetation) samples were collected by hand and generally consisted of spike water milfoil (Myrophyllum spicatum). Samples obtained for radiological analyses required large ( $>600$ grams) quantities of the media and may have included waterweed (Elodea sp.) and pondweed (Potomogeton sp.) as all three species were present at all sites except Location 9, where water velocities and substrate may not have been suitable for this type of vegetation. Samples were placed in glass jars for the metals analyses or plastic bags for the radiological analyses.

Periphyton. Samples of periphyton were scraped from rock surfaces using a rigid plastic card and placed directly into cleaned sample containers. Samples of periphyton were not found at the Vernita Bridge background locations or near Location 7.

\subsection{External Radiation}

Exposure rates from external radiation were measured with a Reuter-Stokes pressurized ionization chamber (model RSS-131). The chamber was connected to a Trimble GPS via a data logger (Trimble model TSC1). Global positioning data and exposure rate $(\mu \mathrm{R} / \mathrm{h})$ data were collected once every second and stored in the data logger. Shoreline areas near the primary shoreline sampling locations were 
traversed along the high water mark and along the river's edge. Similar readings also were collected on the river near the shoreline by boat. Data were transferred to computer using GPS Pathfinder Office 2.70, and exported as ASCII files for use by mapping software.

\subsection{Quality Assurance and Quality Control}

Samples were collected according to the Surface Environmental Surveillance Project Procedures Manual (PNL-MA-580). Samples were issued unique sample numbers and chain of custody was documented on field record forms. Field notes were documented in permanently bound notebooks with photocopies of the notebooks pages placed into the SESP project files.

Analysis of the samples was divided between the Washington State Department of Health and SESP. At some locations, Washington State Department of Health and SESP separately collected and analyzed the same media for quality assurance purposes (Section 4.5 and Appendix D). Severn Trent Laboratory, Richland, Washington, analyzed the SESP radionuclide samples. The Washington State W. R. Giedt Public Health Laboratories (Shoreline, Washington) analyzed Washington State Department of Health samples. Both the SESP and Washington State Department of Health operate under quality assurance programs that include quality control elements to ensure analytical proficiency and accuracy. Both laboratories' quality assurance programs include analysis of samples distributed by the federal government's quality assurance programs; split samples distributed on a smaller scale between cooperating federal, state, and private laboratories; and internal procedures relating to the counting facilities and analytical techniques (Poston et al. 2001). The quality assurance programs assure that sample collection, sample transport, data entry, and analyses were performed in accordance with documented procedures. 


\subsection{Sample Results and Discussion}

Analytical results (both radiological and chemical) for environmental samples collected for this study are presented and discussed in this section. In addition, results of the biological monitoring effect are also presented and discussed.

\subsection{Water}

Water samples collected for this study included riverbank spring water, near-shore water, and shallow groundwater from drive points. In addition, the results from annual sampling efforts at 300 Area nearshore and cross-river transect locations by the SESP and Washington State Department of Health are included in this report. Results from this study will be compared to values determined for a 1992 study of 300 Area riverbank springs, near-shore water, and sediment that was also conducted during a low river stage period (Friant and Hulstrom 1993).

\subsubsection{Near-Shore and River Water}

Radiological Results. Radionuclides consistently detected in near-shore river water included gross alpha, gross beta, tritium, technetium-99, and uranium (Appendix B, Table B.1). Total uranium and gross alpha exceeded the state ambient water quality criteria at Location 9; however, these criteria were only exceeded at the location nearest to the shore ( 0.25 meter depth), which was in the immediate vicinity of a riverbank spring. All other measured river water concentrations were less than ambient surface water quality criteria. Cobalt-60, strontium-90, and cesium-137 were all below minimum detectable levels in the 300 Area near-shore river water samples.

Figure 4.1, Figure 4.2, and Figure 4.3 show the near-shore river water and riverbank spring water concentration profiles for specific conductivity, tritium, and total uranium for the 300 Area near-shore and Vernita Bridge samples (riverbank spring water is discussed separately in Section 4.1.3). All three of these analytes show similar patterns of elevated concentration at the two major riverbank spring areas (Locations 7 and 9), and the highest river water concentrations were found at the nearest-to-shore sample site at Location 9. Generally, the highest concentrations were found at the nearest-to-shore sample sites. The samples taken at greater river depth (equivalent to greater distance from shore) generally had concentrations that decreased with increasing depth.

The river water samples at Locations 7 DR, 9 DR, and 11 DR, located $\sim 100$ meters downriver of the major spring locations generally had lower specific conductivity and concentrations of tritium and uranium than those at the major springs. The concentrations at Locations 7/9, 9/11, and 14 (the farthest sampling site downstream of the 300 Area and near an unimproved public boat launch) were only slightly elevated compared to those at Vernita Bridge.

The data suggest that for the river stage conditions at the time sampling occurred, the major riverbank springs were the primary pathway for radionuclides to enter the river along the 300 Area shoreline. 


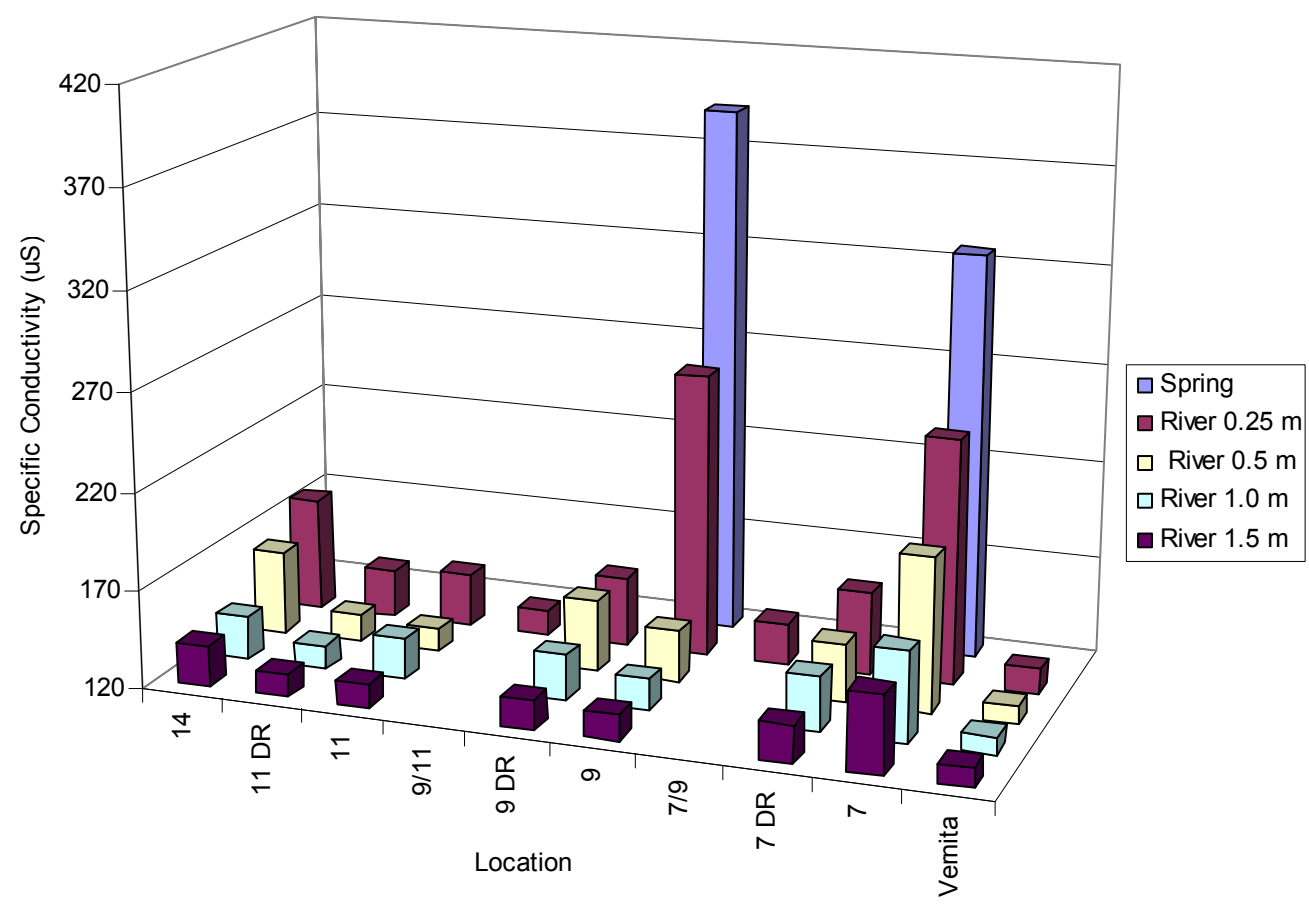

Figure 4.1. Specific Conductivity Measurements for 300 Area and Vernita Bridge Near-Shore River Water and Riverbank Spring Samples

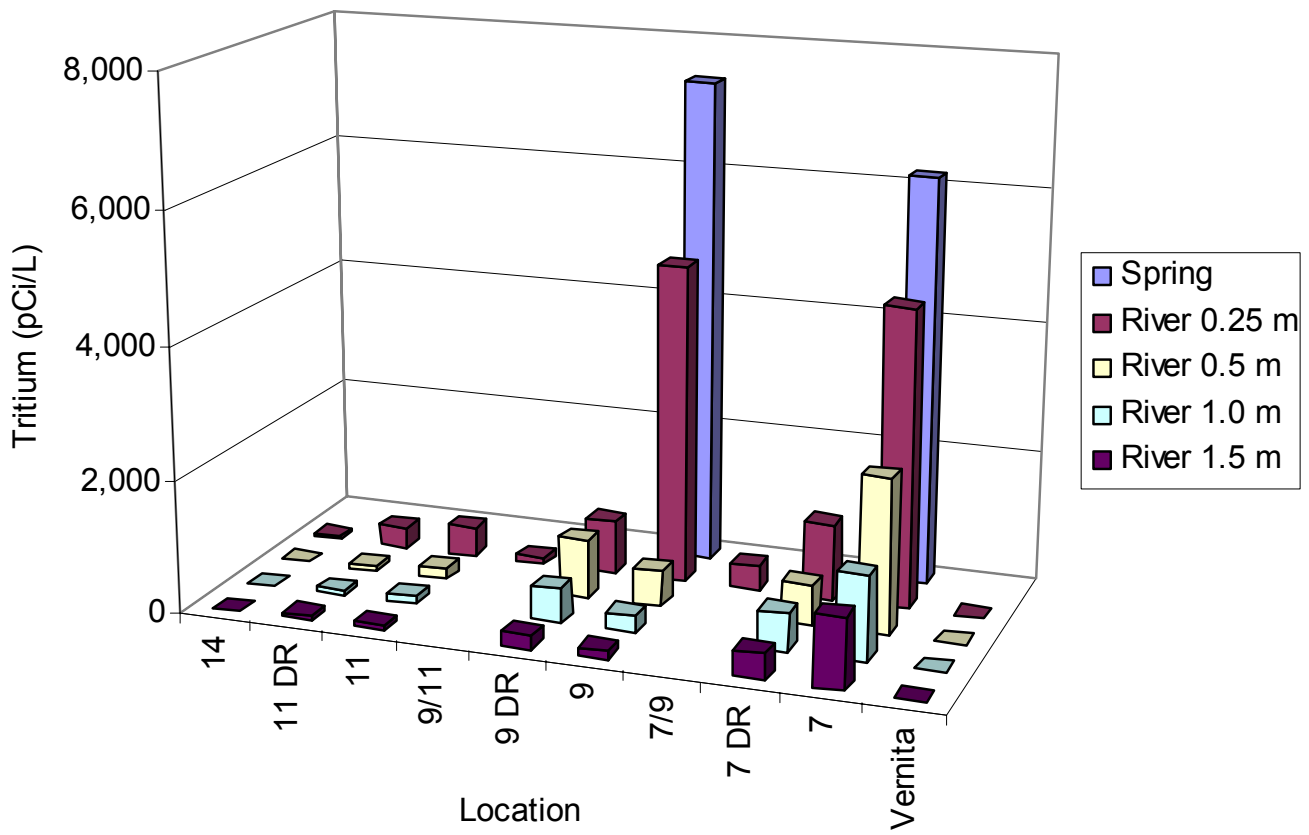

Figure 4.2. Tritium Concentrations for 300 Area and Vernita Bridge Near-Shore River Water and Riverbank Spring Samples 


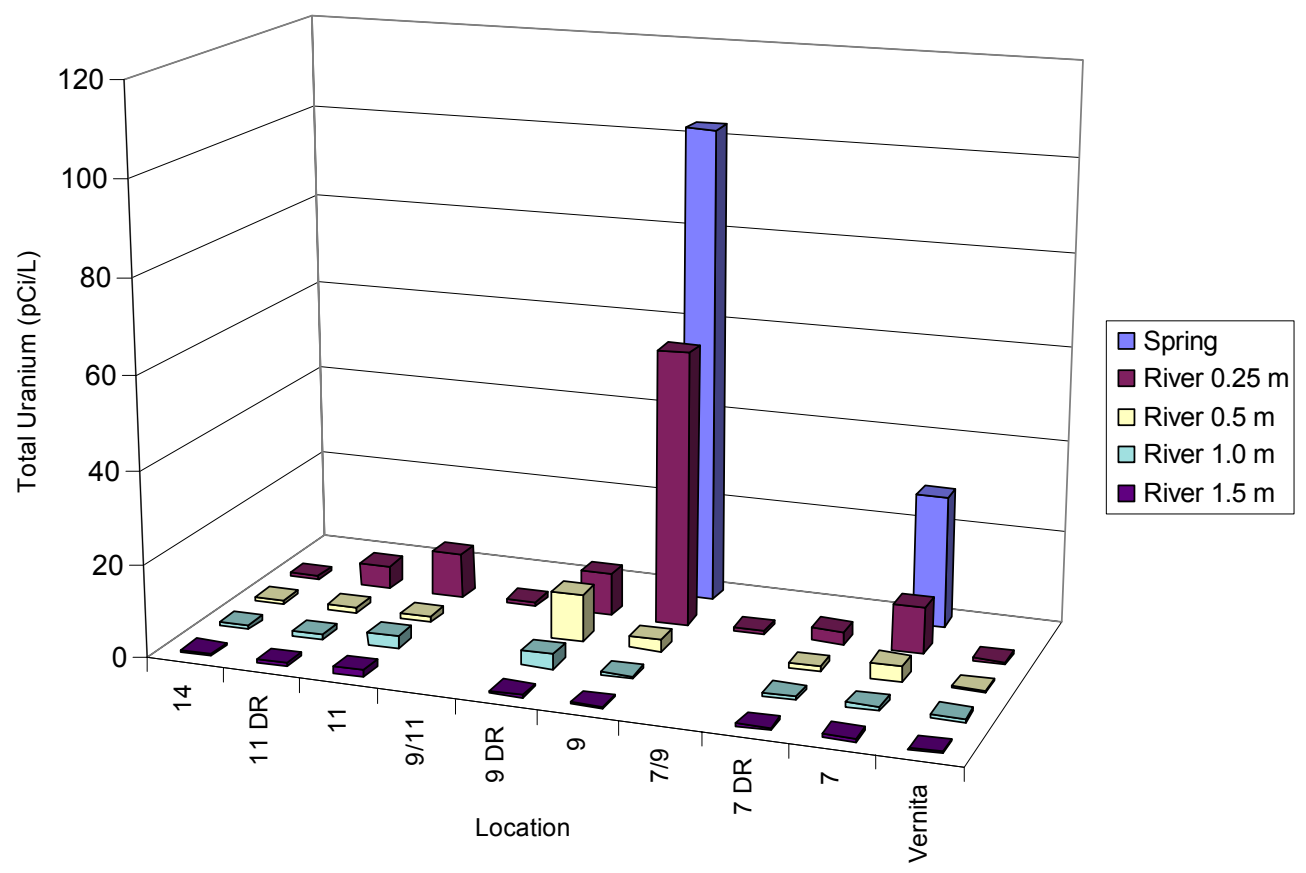

Figure 4.3. Total Uranium Concentrations for 300 Area and Vernita Bridge Near-Shore River Water and Riverbank Spring Samples

Radionuclides upwelling from the river bottom appear to be a less significant pathway since river water concentrations decrease rapidly with increasing river depth. Near-shore water concentrations also decreased with increasing river depth at Location 11 (where no riverbank spring discharge was observed) and $11 \mathrm{DR}$. Thus, in the absence of flowing riverbank springs, diffuse bank seepage can influence the concentration of radionuclides observed in the near-shore river water.

Comparison to 1992 Near-Shore Report. Both the 1992 study (Friant and Hulstrom 1993) and this study collected river water samples perpendicular to the shoreline at the riverbank springs. The 1992 study collected samples from mid-depth at set distances from shore (3, 9, and 20 meters), while the 2001 study collected samples near the river bottom at set depths from the shore $(0.25,0.5,1.0$, and 1.5 meters). However, both studies found that near-shore river water had lower concentrations of tritium and total uranium than the adjacent riverbank spring and that concentrations decreased with distance from the Hanford shoreline.

Chemical Results. The results for near-shore water samples analyzed for metals (filtered and unfiltered) are given in Appendix C, Table C.1. Metals that were detected in 300 Area near-shore river water samples at concentrations above the Vernita Bridge background included chromium, manganese, zinc, arsenic, selenium, barium, and thallium (Figure 4.4). However, all concentrations were below ambient water quality criteria (Appendix A, Table A.2; Note: Not all metals have water quality criteria and for hardness-dependent metal criteria a conservative hardness value of $47 \mathrm{mg} / \mathrm{L}$ as calcium carbonate was used). Near-shore water concentrations (filtered) of chromium and selenium at the 300 Area Locations 7 and 9 were 9 to 15 and 7 to 11 times higher than the Vernita Bridge average, respectively. Filtered water 
concentrations of arsenic, barium, manganese, thallium, and zinc ranged from 1.5 to 3.2 times higher at 300 Area Locations 7 and 9 compared to Vernita Bridge.

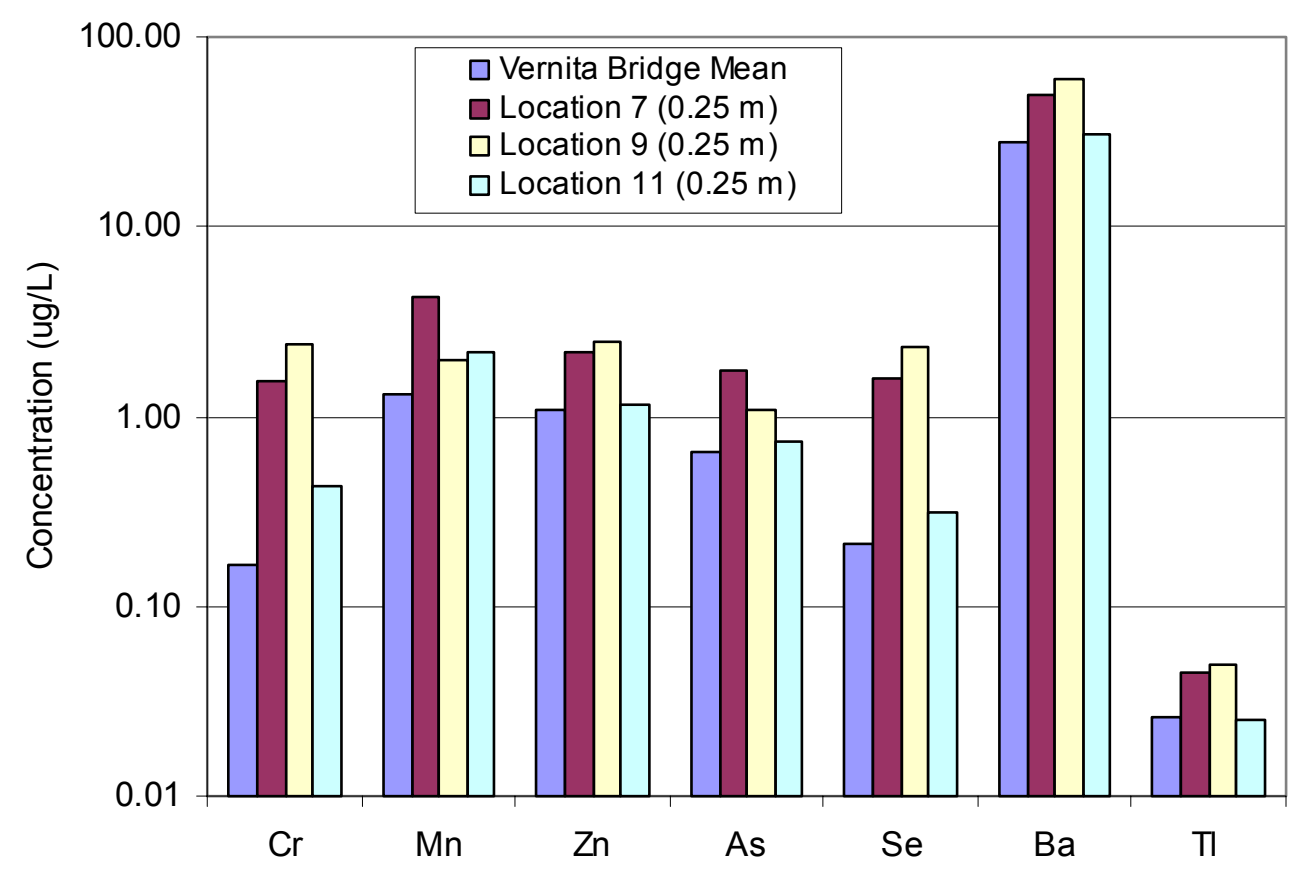

Figure 4.4. Selected Metal Concentrations for 300 Area Near-Shore and Vernita Bridge River Filtered Water Samples

All other detected metals (aluminum, antimony, cadmium, copper, lead, nickel, and silver) had similar concentrations for both the 300 Area near-shore and the Vernita Bridge locations. Beryllium was below the detection limit of $0.008 \mu \mathrm{g} / \mathrm{L}$ for all samples.

\subsubsection{Cross-River Transects and Additional Near-Shore River Water}

Results from samples collected along Columbia River transects and near-shore locations near Vernita Bridge, 100-N, 100-F, Hanford town site, 300 Area, and the Richland pumphouse are reported annually as part of the SESP and Washington State Department of Health Hanford Site surveillance programs (Bisping 2001; Poston et al. 2001). The results for September 2001 sampling in the 300 Area and Vernita Bridge provide information on the distribution of contaminants across the Columbia River while the nearshore samples help determine the localized zone of influence near known discharges of contaminated groundwater via riverbank springs. These results, although discussed here, were not collected as part of this study.

Radiological Results. Radionuclides consistently detected in cross-river transects and near-shore river water samples included tritium, strontium-90, and uranium (Appendix B, Table B.2). All measured concentrations were less than applicable ambient surface water quality criteria levels. Figure 4.5, Figure 4.6, and Figure 4.7 (to simplify viewing, only the SESP data is shown in the figures) show the 
cross-river transects and annual near-shore results for tritium, strontium-90, and total uranium for the 300 Area and Vernita Bridge samples collected in September 2001.

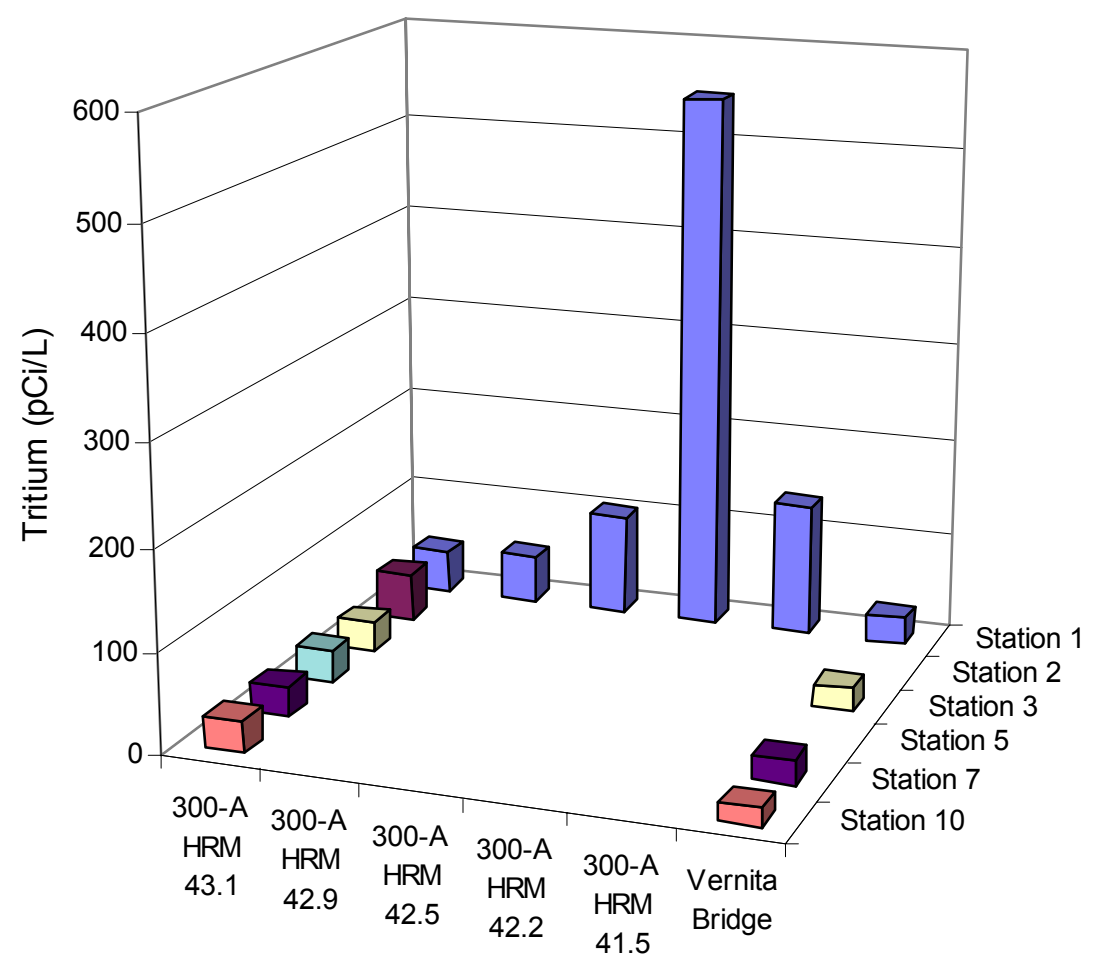

\section{Figure 4.5. Tritium Concentrations in Water Samples from Cross-River Transects and Near- Shore Locations}

The concentration of tritium in all river water samples was less than $150 \mathrm{pCi} / \mathrm{L}$ (see Figure 4.5), with the exception of the near-shore water sample collected at Location 7 (Hanford river marker 42.2) that had a value of $550 \pm 50 \mathrm{pCi} / \mathrm{L}$, which was roughly 20 times higher than the maximum concentration measured at Vernita Bridge. The cross-river transect collected at the southern boundary of the 300 Area (Hanford river marker 43.1) revealed slightly elevated tritium concentrations compared to the values reported for the Franklin County shoreline and the Vernita Bridge locations. However, all tritium concentrations measured were well below the $20,000 \mathrm{pCi} / \mathrm{L}$ ambient water quality standard.

The concentrations of strontium-90 in all river water samples were less than $0.1 \mathrm{pCi} / \mathrm{L}$ with no difference between Vernita Bridge and the 300 Area results. Total uranium concentrations were elevated, compared to Vernita Bridge, for the sample collected at Hanford river marker 42.2 that corresponds to Location 7 for this study. The highest total uranium concentration for the cross-river transect samples is for the Franklin County shoreline directly across from the Richland pumphouse and is most likely related to irrigation water returns (Poston et al. 2001). 


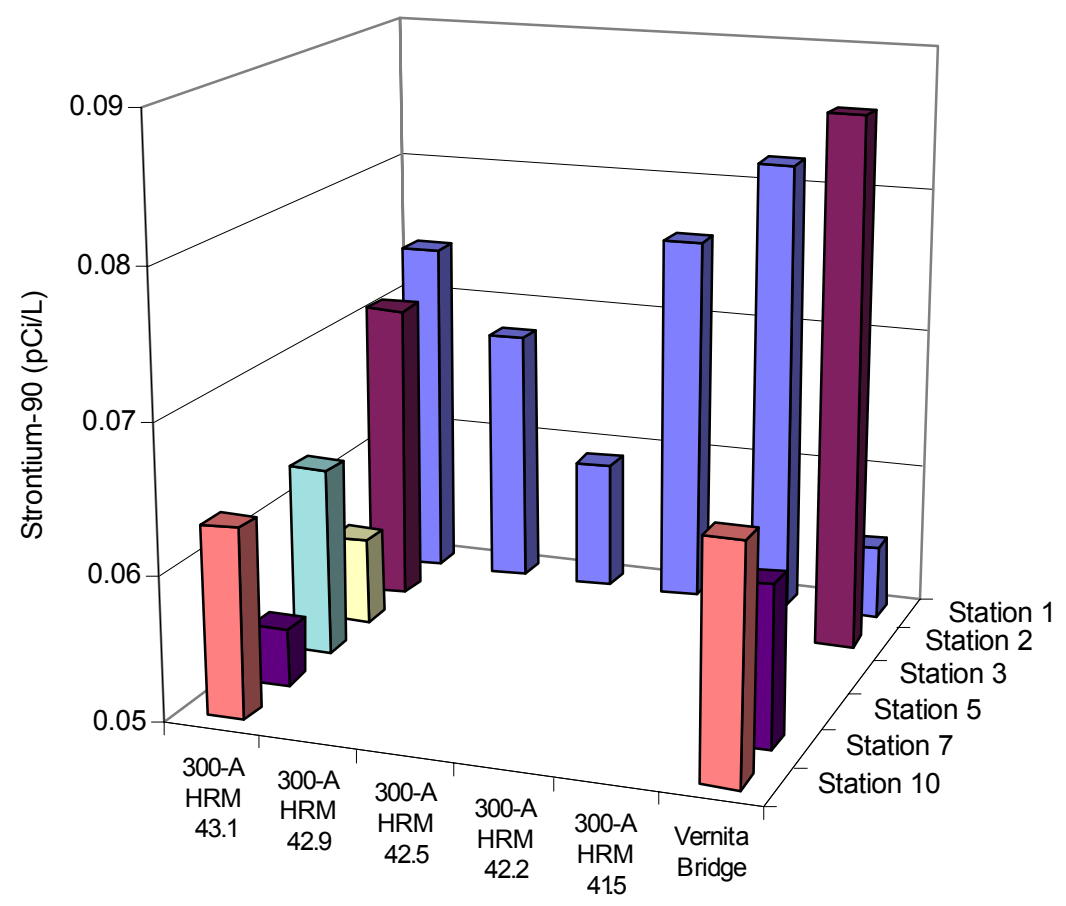

Figure 4.6. Strontium-90 Concentrations in Water Samples from Cross-River Transects and Near-Shore Locations

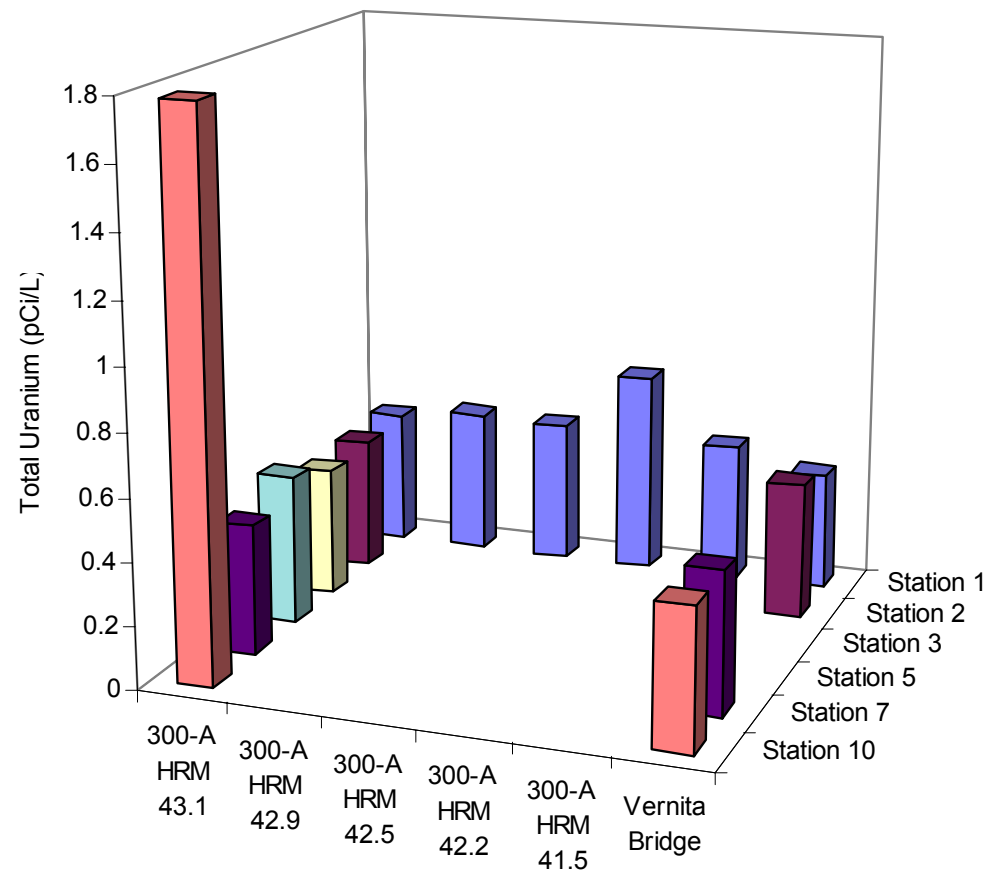

Figure 4.7. Total Uranium Concentrations in Water Samples from Cross-River Transects and Near-Shore Locations 
Chemical Results. Chemical contaminants that were detected in 300 Area and Vernita Bridge crossriver transects and near-shore samples included chloride, fluoride, nitrate, and sulfate (Appendix C, Table C.2). All results were less than ambient water quality criteria and were similar to previous measurements (Dirkes et al. 1993; Poston et al. 2001). The cross-river and near-shore concentrations of chloride, nitrate, and sulfate reveal elevated levels for the samples collected at Location 7 (Hanford river marker 42.1), the Franklin County shoreline at the 300 Area, and the Grant County shoreline at Vernita Bridge. Figure 4.8 shows the nitrate concentrations for the 2001 cross-river transect and near-shore samples. Fluoride was detected in all Columbia River water samples with concentrations similar at Vernita Bridge ( 0.13 to $0.14 \mathrm{mg} / \mathrm{L})$ and the 300 Area $(0.12$ to $0.13 \mathrm{mg} / \mathrm{L})$ and no cross-river gradients were observed.

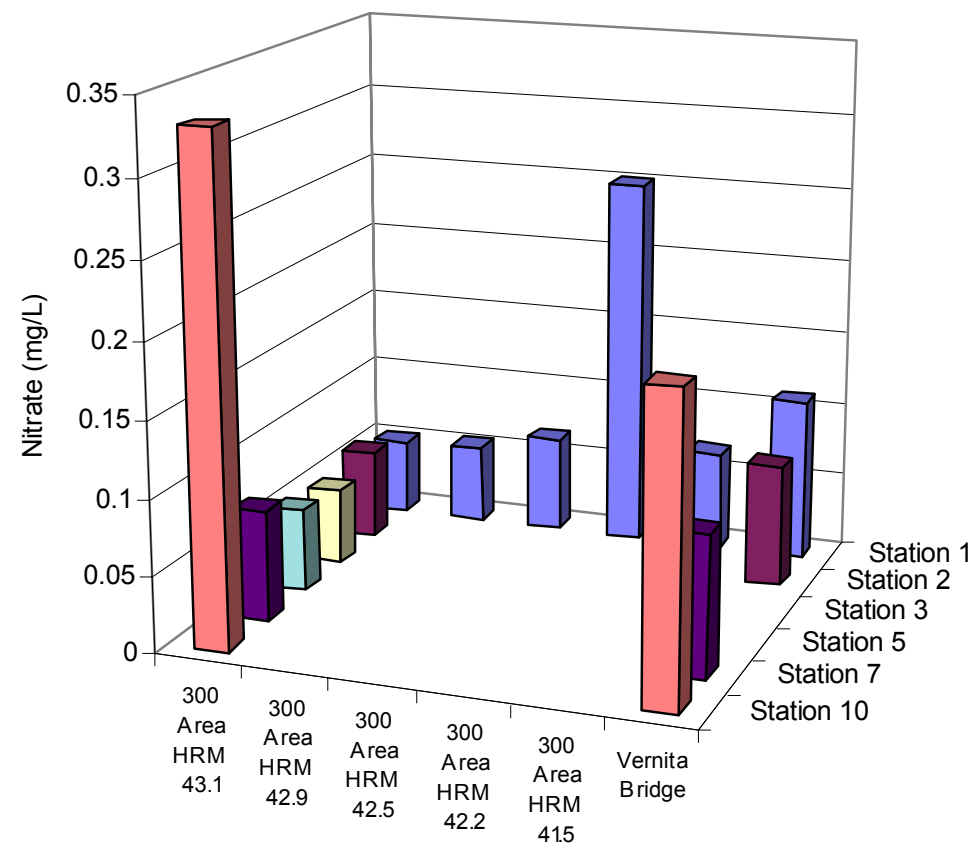

Figure 4.8. Nitrate Concentrations in Water Samples from Cross-River Transects and NearShore Locations

\subsubsection{Riverbank Springs}

Water from riverbank springs was collected at Locations 7 and 9; the springs were dormant at Locations 11 and 14.

Radiological Results. Radionuclides detected in riverbank spring water samples from Locations 7 and 9 included gross alpha, gross beta, tritium (see Figure 4.2), technetium-99, iodine-129, uranium isotopes (see Figure 4.3), and thorium isotopes (Appendix B, Table B.3). Ambient surface water quality criteria levels (WAC 173-201A and WAC 246-290) were exceeded for gross alpha and total uranium (uranium-234 +-235+-238) at both locations. Gross alpha levels for the 300 Area riverbank springs ranged from $27 \pm 7.9$ to $110 \pm 10 \mathrm{pCi} / \mathrm{L}$ and total uranium levels ranged from $28 \pm 0.71$ to $100 \pm$ $13 \mathrm{pCi} / \mathrm{L}$, with the highest concentrations at Location 9. 
Tritium concentrations at both riverbank spring locations ranged from $6,200 \pm 150$ to $8,400 \pm$ $460 \mathrm{pCi} / \mathrm{L}$ and were elevated compared to the Vernita Bridge background concentration of $35 \pm$ $6.9 \mathrm{pCi} / \mathrm{L}$; however, the levels were less than the state ambient surface water criteria value of $20,000 \mathrm{pCi} / \mathrm{L}$. Technetium-99 was detected in riverbank spring water at both locations with a maximum concentration of $34 \pm 3 \mathrm{pCi} / \mathrm{L}$ at Location 9; however, this level was below the state ambient surface water quality criteria of $900 \mathrm{pCi} / \mathrm{L}$. Thorium (thorium-228, -230, and -232) was detected at Location 7 but was near or below the detection limits for samples from Location 9. In contrast to thorium, uranium had higher concentrations at Location 9 compared to Location 7. The thorium concentrations at Location 7 were elevated compared to the Vernita Bridge background site. Iodine-129 concentrations at both riverbank spring locations in the 300 Area ranged from $0.0034 \pm 0.00040$ to $0.0041 \pm 0.00047 \mathrm{pCi} / \mathrm{L}$ and were elevated compared to the maximum concentration measured in 2000 at the SESP background location at Priest Rapids Dam (0.0000082 \pm 0.0000050 pCi/L) (Poston et al. 2001); however, all values from the 300 Area samples were less than the state ambient surface water quality criteria of $1 \mathrm{pCi} / \mathrm{L}$.

Cobalt-60, strontium-90, ruthenium-106, and cesium-137 were not detected in riverbank spring water from the 300 Area.

In addition to traditional radiochemical counting techniques, ICP-MS was used to analyze for uranium isotopes in 300 Area riverbank springs and river water from the Vernita Bridge location. These results are given in Appendix B, Table B.4 and isotopic abundances of uranium-234, -235, and -236 are shown in Figure 4.9. The results for total uranium by ICP-MS were of similar magnitude as the radiological counting results although the ICP-MS values were lower by roughly $20 \%$ to $30 \%$. Both riverbank spring water samples (Locations 7 and 9) had elevated concentrations of all uranium isotopes compared to the Vernita Bridge water samples. However, the uranium isotopic abundances (see Figure 4.9) were similar for all locations and did not reveal isotopic enrichment from fuel production processes at the 300 Area.

Comparison to 1992 Near-Shore Report and 1996-2000 SESP Data. Both the 1992 (Friant and Hulstrom 1993) and this study collected riverbank spring water at Locations 7 and 9. In addition, the SESP project collected annual samples at Location 7 (1996 to 2000) and Location 9 (1999 to 2000) (Poston et al. 2001). Figure 4.10 provides plots of specific conductivity, tritium concentrations, and total uranium concentrations for Location 7 using the 1992, 1996-2000 SESP, and the 2001 (this study) results. At Location 7, contaminant concentrations were directly proportional to specific conductivity measurements with the correlations of $r=0.83$ for tritium verses specific conductivity and $r=0.74$ for total uranium verses specific conductivity. For 1992 to 2001, total uranium concentrations ranged from $29 \pm 3.6$ to $110 \pm 6.1 \mathrm{pCi} / \mathrm{L}$. Tritium concentrations ranged from $3,400 \pm 360$ to $10,000 \pm 530 \mathrm{pCi} / \mathrm{L}$ and specific conductivity ranged from 320 to $412 \mu \mathrm{S}$. Overall, the concentrations of tritium and total uranium remained similar throughout this time period. However, assessing concentration trends for total uranium is difficult because in some cases samples with similar specific conductivity had a two-fold difference in total uranium levels.

For Location 9, data was only available for 1992, 1999, 2000, and 2001. It appears that concentrations of tritium and total uranium have increased at this location since 1992. However, the 1992 samples had a relatively low specific conductivity of $277 \mu \mathrm{S} / \mathrm{cm}$ compared to 1999, 2000, and 2001 samples, 
which had specific conductivity values that ranged from 390 to $455 \mu \mathrm{S} / \mathrm{cm}$; therefore, direct comparisons are difficult. The 1992 results $(277 \mu \mathrm{S} / \mathrm{cm}$ conductivity) were $26 \pm 3.3 \mathrm{pCi} / \mathrm{L}$ for total uranium and 2,800 $\pm 250 \mathrm{pCi} / \mathrm{L}$ for tritium compared to 2001 values $(390 \mu \mathrm{S} / \mathrm{cm}$ conductivity) of $100 \pm 13 \mathrm{pCi} / \mathrm{L}$ for total uranium and $8,400 \pm 460 \mathrm{pCi} / \mathrm{L}$ for tritium.

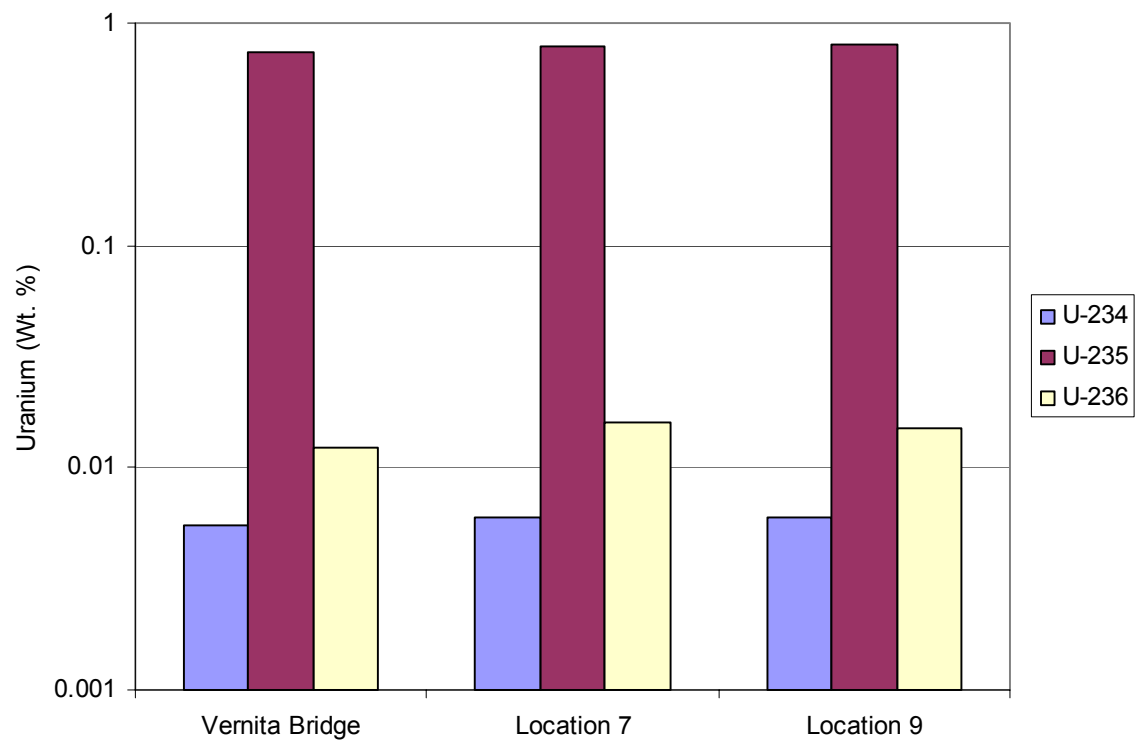

Figure 4.9. Isotopic Abundance of Uranium (U-234, U-235, and U-236) in River Water from Vernita Bridge and Riverbank Spring Water from the 300 Area (ICP-MS data)

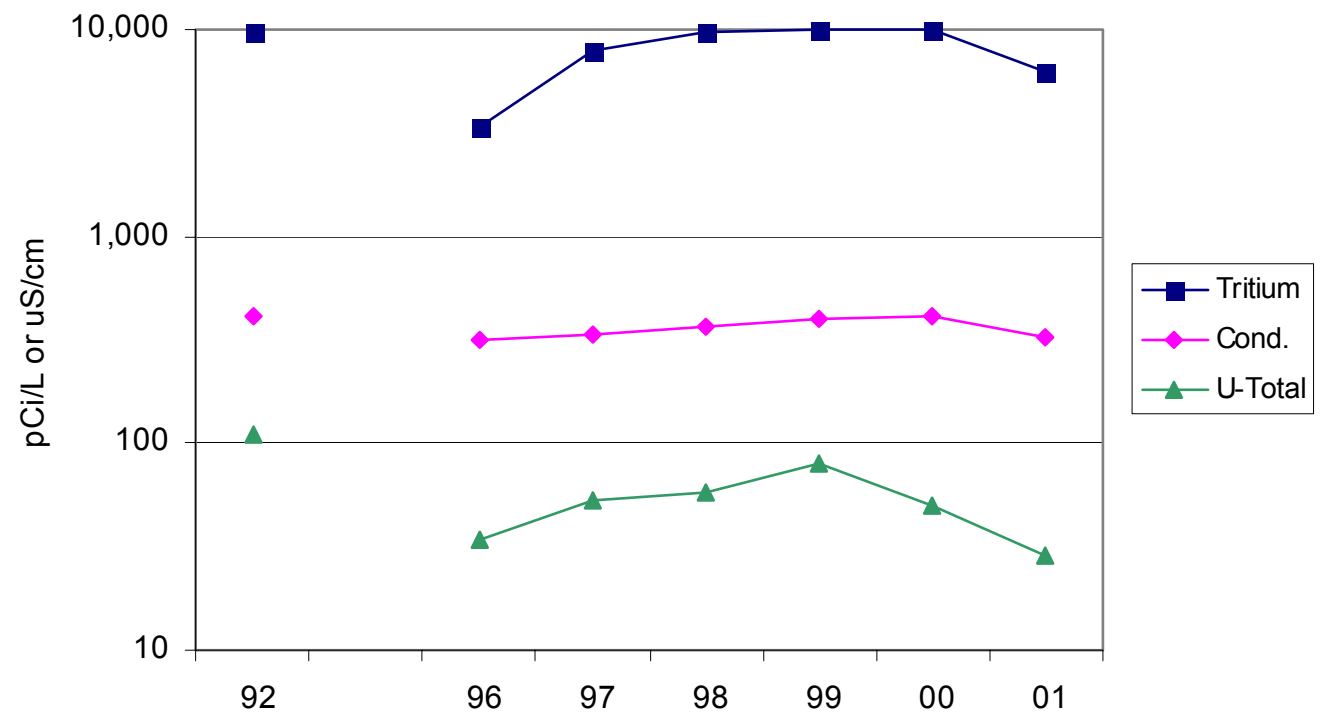

Figure 4.10. Tritium, Total Uranium, and Specific Conductivity for 1992 to 2001 Riverbank Spring Water at Location 7 
Chemical Results. The results for riverbank water samples analyzed for metals (filter and unfiltered) are given in Appendix C, Table C.1. Metals in filtered 300 Area near-shore riverbank water samples with concentrations at least twice the average Vernita Bridge background included aluminum, barium, cadmium, chromium, thallium, selenium, and zinc (Figure 4.11). However, all concentrations were below freshwater ambient water quality criteria (Appendix A, Table A.2). Not all metals have water quality criteria and for hardness-dependent metal, a conservation value of $47 \mathrm{mg} / \mathrm{L}$ as calcium carbonate was used. Uranium was analyzed by ICP-MS and the results are reported in both radiological and chemical units in Appendix B, Table B.4; uranium results are discussed in the radiological results section.

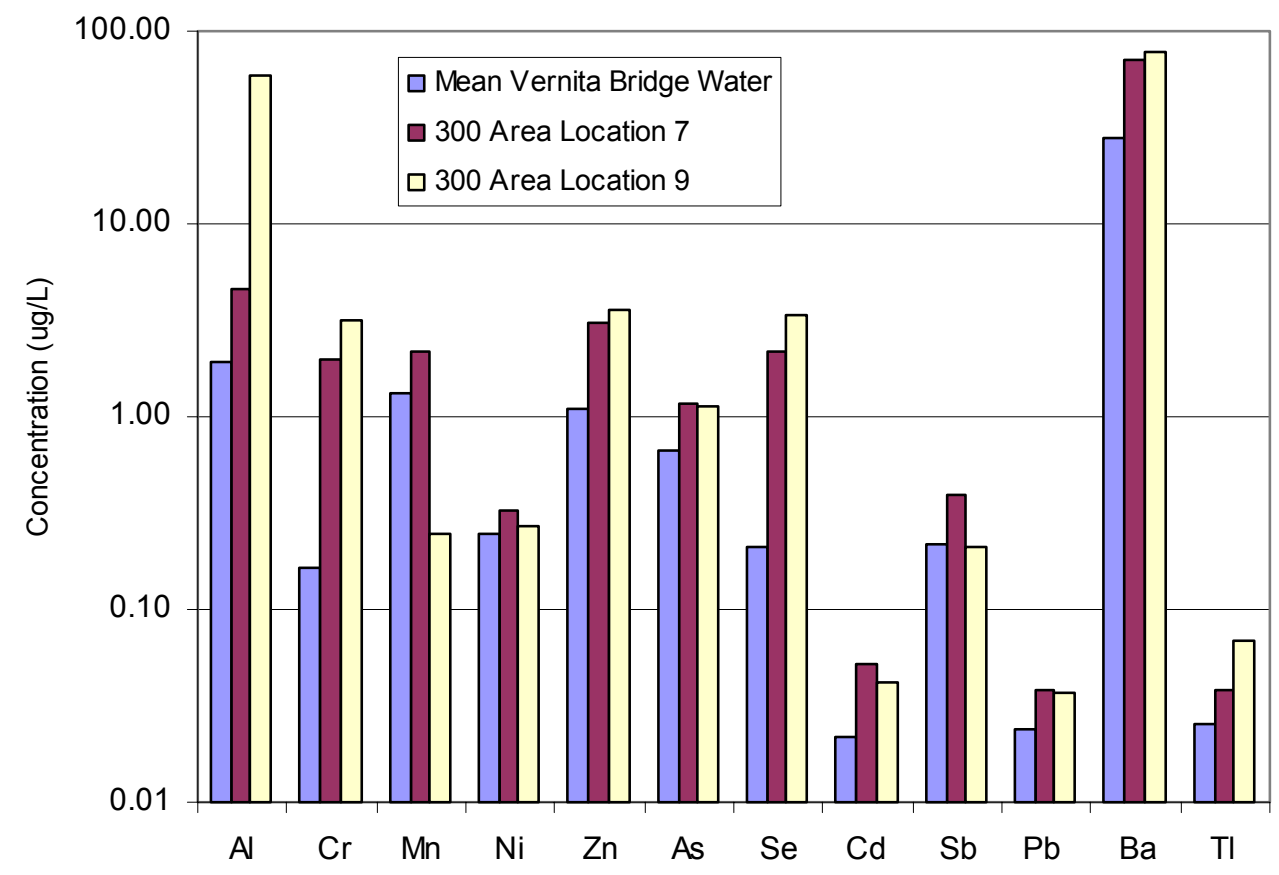

Figure 4.11. Selected Metal Concentrations in Filtered Water Samples from 300 Area Riverbank Springs and River Water at Vernita Bridge

Filtered riverbank spring water concentrations of chromium and selenium at the 300 Area Locations 7 and 9 were 12 to 19 and 10 to 16 times higher than average Vernita Bridge results, respectively. Aluminum concentrations in riverbank spring water were 2.4 and 31 times higher at Locations 7 and 9 compared to Vernita Bridge samples, respectively. However, despite the elevated level of aluminum in riverbank spring water at Location 9, the near-shore river water sample at Location 9 had aluminum concentrations similar to background.

Riverbank spring water concentrations of barium, cadmium, thallium, and zinc ranged from 1.5 to 3.3 times higher at 300 Area Locations 7 and 9 compared to Vernita Bridge. All other detected metals (antimony, arsenic, copper, lead, manganese, nickel, and silver) had similar (less than a factor of two difference) water concentrations for both the 300 Area riverbank springs and the Vernita Bridge locations. Beryllium levels were below a detection limit of $0.008 \mu \mathrm{g} / \mathrm{L}$ for all samples. Mercury was detected in filtered water samples from riverbank spring water at Locations 7 and 9 and at the Vernita Bridge site; however, all values were similar and well below the chronic ambient water quality criteria of $0.012 \mu \mathrm{g} / \mathrm{L}$. 
Water samples from riverbank spring Locations 7 and 9 and the Vernita Bridge sites were analyzed for 23 volatile organic compounds by gas chromatography-mass spectrometry using EPA Method 8260 (Appendix C, Table C.3). All results were below the detection limits except for trichloroethylene $(2 \mu \mathrm{g} / \mathrm{L})$ and cis-dichloroethylene $(0.32 \mu \mathrm{g} / \mathrm{L})$ at Location 9 , and possibly methylene chloride. The trichloroethylene concentration in riverbank spring water from Location 9 was $\sim 7$ times higher than the detection limit of $0.29 \mu \mathrm{g} / \mathrm{L}$; however, the cis-dichloroethylene concentration was $<1.4$ times the detection limit of $0.24 \mu \mathrm{g} / \mathrm{L}$. Several of the results for methylene chloride were flagged with both a "J" and "B" data qualifier by the analytical laboratory. The "J" and "B" data qualifiers means that the reported values were less than the contract reportable limit but above the minimum detectable limit, and that the analytical blank associated with the sample had a reported value above the minimum detectable value; respectively. Methylene chloride in riverbank spring water samples from Location $7(0.56 \mu \mathrm{g} / \mathrm{L})$, Location $9(0.66 \mu \mathrm{g} / \mathrm{L})$, and one of two river water samples at Vernita Bridge $(0.58 \mu \mathrm{g} / \mathrm{L})$ were reported from the analytical lab with "JB" data qualifiers. Therefore, the values for methylene chloride are suspect because of the blank contamination and values near the detection limit.

Comparison to 1992 Near-Shore Report. For metals, both the 1992 (Friant and Hulstrom 1993) and 2001 riverbank sampling efforts generally had similar results for filtered riverbank spring water samples collected from Locations 7 and 9. However, the 1992 study had higher limits of detection and several results were flagged as having blank contamination. The largest differences between the two sampling periods were for lead and zinc. Lead concentrations were below $0.04 \mu \mathrm{g} / \mathrm{L}$ for 2001 samples from both locations, whereas the 1992 results were $2.4 \mu \mathrm{g} / \mathrm{L}$ at Location 7 (flagged for blank contamination) and $1.9 \mu \mathrm{g} / \mathrm{L}$ at Location 9. Zinc concentrations in the 1992 study $(28 \mu \mathrm{g} / \mathrm{L}$ at Location 7 and $43 \mu \mathrm{g} / \mathrm{L}$ at Location 9) were roughly 10 times higher than the $2001 \mathrm{results}(3.0 \mu \mathrm{g} / \mathrm{L}$ at Location 7 and $3.6 \mu \mathrm{g} / \mathrm{L}$ at Location 9). Barium concentrations were roughly 1.5 times higher for the 1992 results, compared to the 2001 values; however, both 1992 results for barium were flagged for blank contamination.

For volatile organics, both the 1992 (Friant and Hulstrom 1993) and 2001 riverbank spring sampling efforts had similar results for samples collected from Locations 7 and 9. For 1992, all results below the detection limit of $10 \mu \mathrm{g} / \mathrm{L}$ for both locations. The 2001 samples had a lower detection limit and all results for both Location 7 and Location 9 were below $1 \mu \mathrm{g} / \mathrm{L}$ (except for ethyl cyanide which was below $2 \mu \mathrm{g} / \mathrm{L})$; except for Location 9 where trichloroethylene $(2.0 \mu \mathrm{g} / \mathrm{L})$ and cis-dichloroethylene $(0.32 \mu \mathrm{g} / \mathrm{L})$ were detected.

\subsubsection{Shallow Groundwater Drive Points}

The results for shallow groundwater collected from drive points are given in Appendix B, Table B.5. The drive point samples had higher conductivity than the riverbank spring water and the values generally increased with depth below the riverbed (Figure 4.12). Tritium, technetium-99, and uranium concentrations were elevated compared to river water and the background water concentration at Vernita Bridge. However, the concentrations of tritium, technetium-99, and uranium were similar to the values reported for the riverbank spring water from the same locations. All total uranium concentrations for 300 Area near-shore drive point samples were above the ambient water quality criteria with values ranging from 64 to $143 \mathrm{pCi} / \mathrm{L}$ (Figure 4.13). Tritium concentrations (Figure 4.14) for the drive point water samples were all below the ambient water quality criteria $(20,000 \mathrm{pCi} / \mathrm{L})$ and ranged from 6,060 to $8,660 \mathrm{pCi} / \mathrm{L}$. The tritium concentrations generally increased with increased depth below the riverbed; however, there was 
no clear trend in concentration verses depth below the riverbed for the uranium values. Technetium-99 concentrations were all below the ambient water quality criteria $(900 \mathrm{pCi} / \mathrm{L})$ and ranged from 9.1 to $26 \mathrm{pCi} / \mathrm{L}$. All results for gamma-emitting radionuclides in the shallow groundwater samples were below the detection limits.

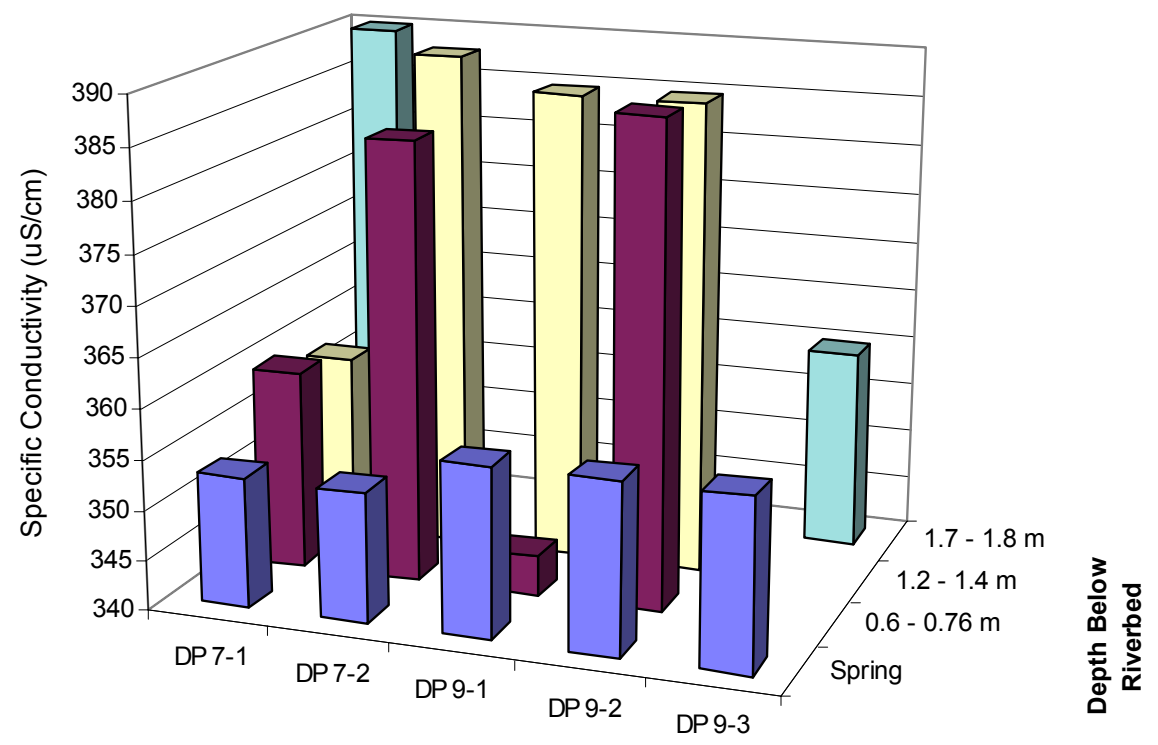

Figure 4.12. Specific Conductivity Measurements for Water Samples Collected from 300 Area Shallow Groundwater (drive point samples)

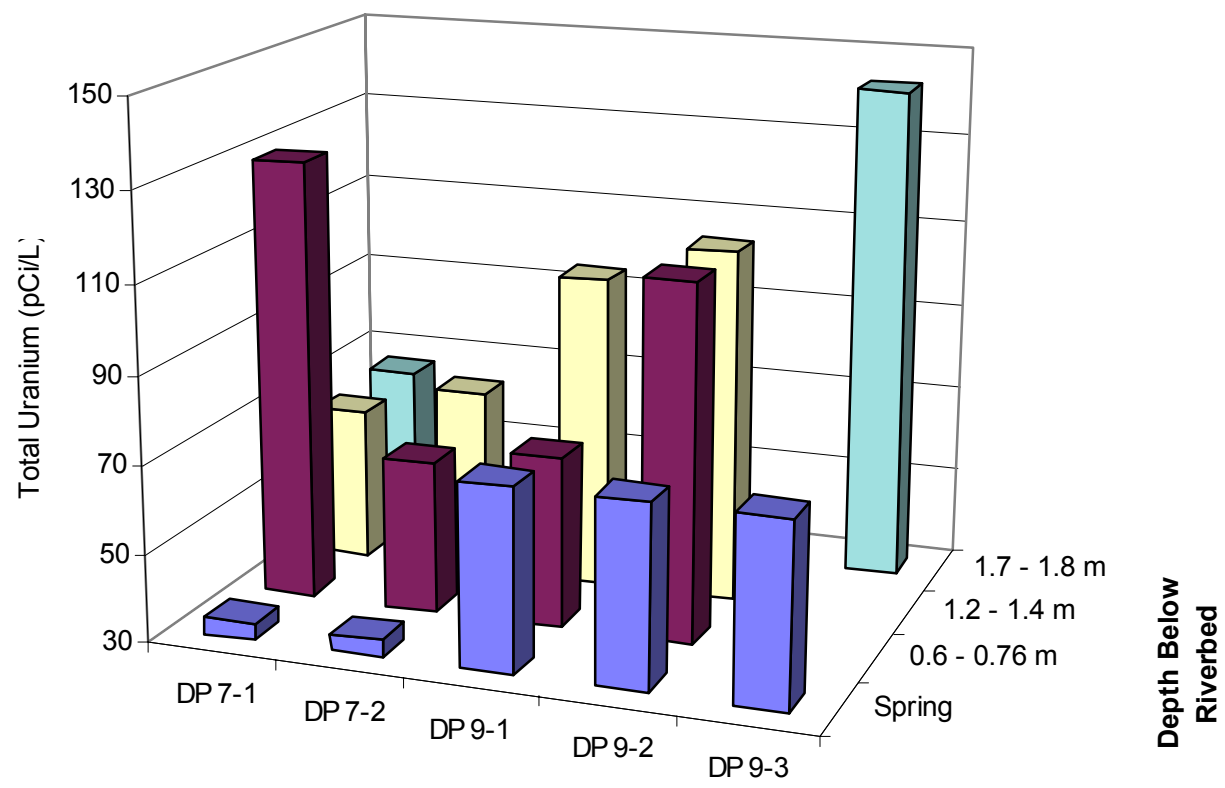

Figure 4.13. Total Uranium Concentrations for Water Samples Collected from 300 Area Shallow Groundwater (drive point samples) 


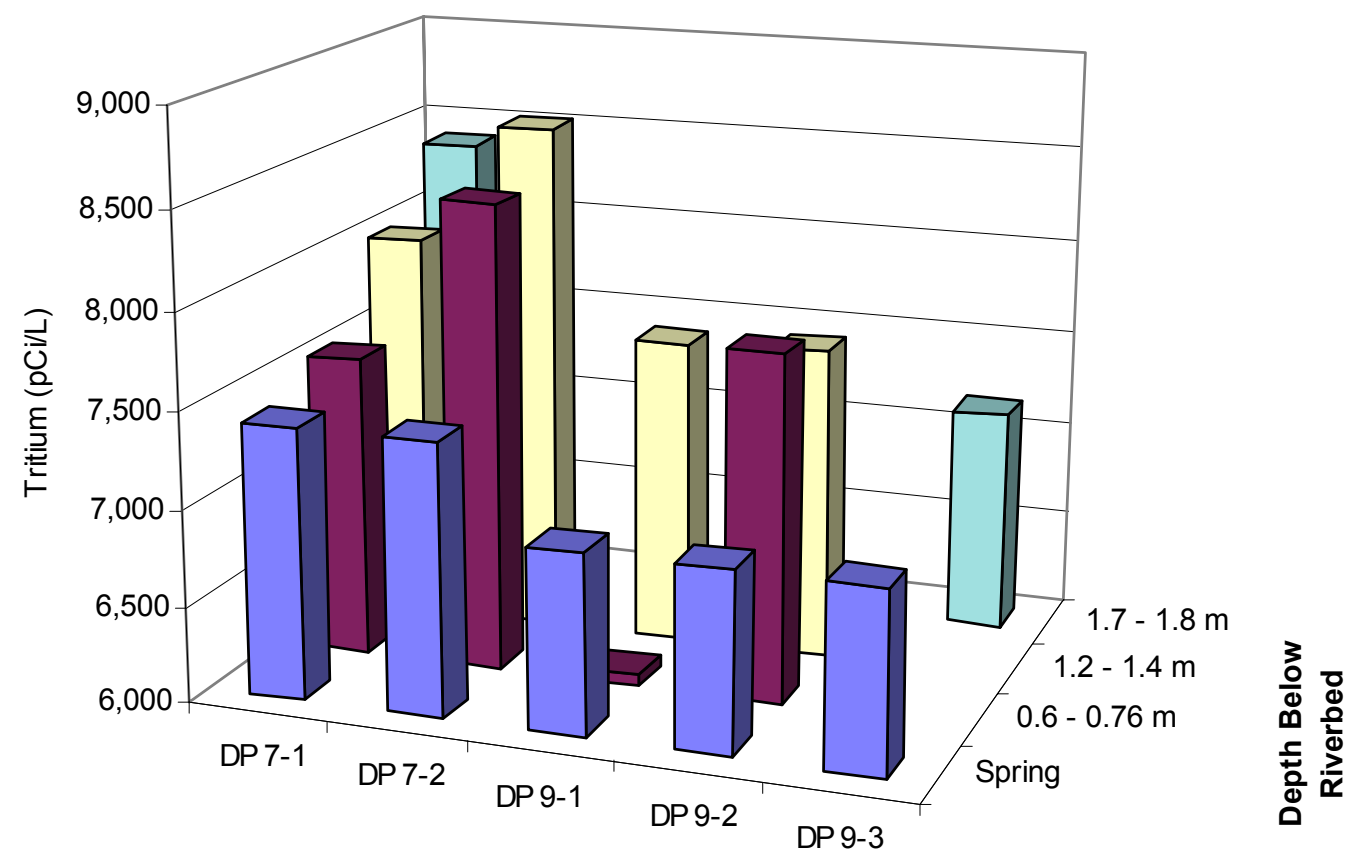

Figure 4.14. Tritium Concentrations for Water Samples Collected from 300 Area Shallow Groundwater (drive point samples)

\subsection{Sediment}

Analytical results for sediment samples and a comparison to results from previous study is provided in this section.

\subsubsection{Radiological Results}

Sediment samples for the major riverbank spring locations in the 300 Area (Location 7, 9, 11, and 14) and the background location (Vernita Bridge) were analyzed for gross beta, gamma-emitting isotopes, strontium-90, technetium-99, isotopic uranium, and isotopic thorium (Appendix B, Table B.6). Concentrations of strontium-90, cesium-137, and isotopic uranium were elevated for the 300 Area samples compared to Vernita Bridge.

Sediment was analyzed for strontium-90 at Locations 7, 9, and Vernita Bridge with concentrations of $0.012 \pm 0.05 \mathrm{pCi} / \mathrm{g}$ dry weight (below detection limit), $0.026 \pm 0.007 \mathrm{pCi} / \mathrm{g}$ dry weight, and $0.003 \pm$ $0.005 \mathrm{pCi} / \mathrm{g}$ dry weight (below detection limit), respectively. These values were all within the range reported for background sediment collected from the Priest Rapids Dam reservoir during 1995 to 2000 (Poston et al. 2001).

Cesium-137 was detected for all 300 Area sediment locations, but was below a nominal detection limit of $0.006 \mathrm{pCi} / \mathrm{g}$ at the Vernita Bridge background location. The highest sediment concentration was at Location $9(0.23 \pm 0.03 \mathrm{pCi} / \mathrm{g}$, with Location 11 having the second highest concentration 
$(0.11 \pm 0.02 \mathrm{pCi} / \mathrm{g})$. These values were all within the range reported for background sediment collected from the Priest Rapids Dam reservoir during 1995 to 2000 (Poston et al. 2001).

The concentrations of uranium (uranium-234, -235, and -238) isotopes at all 300 Area sediment locations were elevated compared to Vernita Bridge. The order of concentration (highest to lowest) was Location 9, Location 7, Location 11, and Location 14 for all isotopes. Sediment from Location 9 had a total uranium concentration of $8.3 \mathrm{pCi} / \mathrm{g}$, which was $\sim 4.4$ times higher than the Vernita Bridge value (Washington State Department of Health data). The total uranium concentration at the farthest downstream location was only 1.6 times higher than the Vernita Bridge value (SESP data). In addition, uranium-236 was detected in all sediment samples (Appendix B, Table B.4) from the 300 Area near shore with concentrations ranging from 0.024 to $0.039 \mathrm{pCi} / \mathrm{g}$. The analytical laboratory reported a less than detection value for uranium-236 at the Vernita Bridge background location.

The concentrations of total beta, technetium-99, and thorium isotopes were similar for both 300 Area near-shore and Vernita Bridge sediment.

\subsubsection{Comparison to 1992 Near-Shore Report}

The only location where sediment samples were collected for both the 1992 (Friant and Hulstrom 1993) and 2001 sampling efforts was Location 7. The results were similar for both time periods.

Strontium-90 concentrations were below the detection limits for both efforts. Cesium-137 concentrations were $0.12 \pm 0.4$ for 1992 and $0.051 \pm 0.016 \mathrm{pCi} / \mathrm{g}$ for 2001 . Total uranium levels were $4.6 \pm 0.59 \mathrm{pCi} / \mathrm{g}$ for 1992 and $5.3 \pm 0.66 \mathrm{pCi} / \mathrm{g}$ for 2001. Gross beta concentrations were $24 \pm 4.9 \mathrm{pCi} / \mathrm{g}$ for 1992 and $30 \pm 5.1 \mathrm{pCi} / \mathrm{g}$ for 2001. Although not measured for the $2001 \mathrm{study}$, the 1992 study conducted sediment grain size analysis for a number of 300 Area riverbank spring sediment samples and found that most of the material was coarse material (i.e., not fines) and were not expected to have high retention for contaminants.

\subsubsection{Chemical Results}

Sediment samples for the major riverbank spring locations and the background location (Vernita Bridge) were analyzed for antimony, arsenic, beryllium, cadmium, chromium, copper, lead, mercury, nickel, selenium, silver, thallium, and zinc (Appendix C, Table C.4). Most results were at or below the concentrations reported for the Vernita Bridge sediment and were similar to those reported in other studies (Blanton et al. 1995; Patton and Crecelius 2001; Poston et al. 2001). The highest concentrations of antimony, beryllium, copper, lead, nickel, and silver were reported for the Vernita Bridge location. Cadmium and zinc concentrations in sediment from Location 9 were 1.6 and 1.4 times higher than the Vernita Bridge sediment. Concentrations of all other metals in the 300 Area near-shore sediment was similar to or lower than the Vernita Bridge sediment. The measured metal concentrations for Location 7 was generally higher for this study than for the 1992 near-shore study (Friant and Hulstrom 1993) and likely resulted from different analytical processing. However, both studies generally found that metal concentrations in the 300 Area riverbank spring sediment were similar to background values.

Currently, there are no freshwater sediment quality criteria available from EPA or Washington State to compare sediment metals concentrations determined by the study (WAC 173-204; Bates and Cubbage 
1995). However, the Ontario Ministry of Environment and Energy has developed some comparative guidelines for the protection and management of aquatic sediment quality (Persaud et al. 1992) and interim sediment quality assessment values have been developed by Environment Canada (EC 1994).

The Ontario sediment criteria are based on a screening level concentration approach that uses field data (contaminant concentrations and benthic biota abundance) and a ranking process to derive sediment criteria. Bates and Cubbage (1995) report that the screening level concentration approaches are advantageous because they are based on chronic population-level effects on indigenous benthic species; however, they are limited in that they do not establish a direct cause and effect relationship between an individual contaminant and biotic survival. The Ontario guidelines have two effect levels for metals:

- lowest effect level which indicates a metal concentration that can be tolerated by most benthic organisms

- severe effect level at which a pronounced impact to benthic organisms can be expected.

The Environment Canada interim sediment quality assessment values are based on a modified national status and trends program that uses data from multiple approaches such as equilibrium partitioning studies, spiked sediment toxicity studies, field sample bioassays, and sediment criteria from other regulatory agencies (Bates and Cubbage 1995). This approach for deriving sediment criteria has the advantage of using a wide range of data sources, but is limited because individual studies are not always comparable because of differing sediment geochemistry, biotic communities, and variability in analytical test methods. The Environment Canada values have two effect levels:

- threshold effect level below which adverse impacts to benthic organisms are rarely observed

- probable effect level where adverse effects to benthic organisms are frequently observed.

Sediment quality for the 300 Area near-shore and Vernita Bridge sediment samples were evaluated by comparing the maximum metal concentrations to the guidelines in Appendix A, Table A.3. No sediment quality criteria were available for antimony, beryllium, selenium, or thallium. All metal concentrations in the 300 Area near-shore sediment were below both the Ontario severe effect level and the Environment Canada probable effect level. Metals concentrations of arsenic, cadmium, chromium, copper, lead, nickel, and zinc were above or similar to the Ontario lowest effect level and the Environment Canada threshold effect level.

\subsection{Biological Monitoring}

The ability of organisms to accumulate and concentrate pollutants from the aquatic environment into their bodies has been known for sometime; however, the practical utility of biota as a contaminant surveillance tool was only widely recognized in the 1960s when low concentrations of radionuclides present in seawater limited the ability to detect ambient levels, but sampling and analyzing bi-valve organisms were able to identify areas with elevated levels of radionuclides (Rosenberg and Resh 1993). Biological monitoring can be generally split into two disciplines: (1) biological surveillance to detect the 
presence and relative abundance of contaminants in a given ecosystem and (2) biological indicators of damage or injury to the ecosystem induced by elevated levels of contamination.

Organisms that are best suited for a biological surveillance program are termed "sentinel species." Whereas ideal "indicator species" are those organisms (or defined assemblages of organisms) that are sensitive to elevated levels of contaminants in their environment and the "end-point" (manifestations of injury that may be critical to individual- or population-level survival) is measurable at some stage in the organism's life history (i.e., healthy organs and tissues, growth rates, survival rates, recruitment rates). In practice, the desirable features of both the sentinel and indicator species are often found only in a limited number of organisms present in the environment. The organisms that were chosen for biological monitoring represented the best available combination of ideal sentinel and indicator species features (Rosenberg and Resh 1993).

The focus of the biological surveillance was to (1) identify and quantify the degree of contaminant accumulation within various components of the riparian and aquatic ecosystems that exist along the 300 Area shoreline and (2) identify which biota were best suited to monitor the biological attenuation of the contaminants over time. Cursory measurements of organism health were also documented for some biota sampled.

\subsubsection{Riparian and Aquatic Community Surveillance}

Samples of available biota and tissues were collected at each of the five sites in this study and analyzed for a suite of contaminants (Table 4.1). Efforts were made to collect biota at each sampling site but this was not always possible. Although biota chosen for this study would ideally be found at all study locations this was not possible because of geographical, physical, biological, and perhaps chemical variations within both riparian and aquatic communities along the Columbia River. In the riparian community, samples of the perennial vegetation (white-sweet clover), mulberry tree, small mammals (house mouse), and invertebrates (darkling beetles) were taken when found. In the aquatic community, samples of aquatic vegetation (macrophytes - milfoil, potomogeton, Elodea), periphyton (algae and diatoms growing on rock surfaces), crayfish, Asian clams, and a small resident predatory fish, the prickly sculpin were collected.

\subsubsection{Radiological Surveillance}

Single composite samples of tree leaves, perennial vegetation, small mammals, macrophytes (aquatic vegetation), sculpin, and crayfish at each site were prepared and analyzed for technetium-99, strontium-90, isotopic uranium (in selected samples by the Washington State Department of Health) and gamma-emitting radionuclides (Appendix B, Table B.7). While several gamma-emitting radionuclides were reported, positive results of manmade radionuclides were only observed for cesium-137. Because of limited amount of sample material, uranium was assayed by ICP-MS in many samples. For radiological comparisons of dose, gravimetric values of uranium concentrations were converted to activity concentrations. However, to assess the accumulation and distribution of uranium in biota, samples were evaluated as gravimetric values (Section 4.4.3). 
Table 4.1. Summary of Biotic Samples

\begin{tabular}{|c|c|c|c|c|c|c|c|c|}
\hline \multirow[b]{2}{*}{ Biota-Types } & \multicolumn{7}{|c|}{300 Area Nearshore Characterization Study Locations } & \multirow[b]{2}{*}{ Analytes Reported } \\
\hline & Vernita & 7 & $7 / 9$ & 9 & $9 / 11$ & 11 & 14 & \\
\hline $\begin{array}{l}\text { RIPARIAN COMMUNITY } \\
\text { Riparian Perennial Vegetation (sweet clover) } \\
\text { Riparian Tree (mulberry leaves) } \\
\text { Invertebrates (darkling beetles) } \\
\text { Small Mammal (House Mouse-carcass) } \\
\text { Small Mammal (House Mouse - kidney) } \\
\text { Small Mammal (House Mouse - liver) }\end{array}$ & $\begin{array}{l}1 \\
1 \\
1 \\
0 \\
0 \\
0\end{array}$ & $\begin{array}{l}1 \\
1 \\
1 \\
1 \\
3 \\
3\end{array}$ & & $\begin{array}{l}1 \\
1 \\
1 \\
0 \\
0 \\
0\end{array}$ & & $\begin{array}{l}1 \\
1 \\
1 \\
1 \\
4 \\
4\end{array}$ & $\begin{array}{l}1 \\
1 \\
1 \\
1 \\
2 \\
2\end{array}$ & $\begin{array}{l}\text { gamma, Sr-90, Tc-99, U-isotopic, Tot-U, Metals } \\
\text { gamma, Sr-90, Tc-99, U-isotopic, Tot-U, Metals } \\
\text { Tot-U, Metals } \\
\text { gamma, Sr-90, Tc-99 } \\
\text { Tot-U } \\
\text { Tot-U, Metals }\end{array}$ \\
\hline Small Mammal (House Mouse - skin) & 0 & 3 & & 0 & & 4 & 2 & Tot-U \\
\hline \multicolumn{9}{|l|}{ AQUATIC COMMUNITY } \\
\hline Periphyton (algae/diatoms) & 0 & 0 & & 1 & & 1 & 1 & Tot-U, Metals \\
\hline $\begin{array}{l}\text { Macrophytes (millfoil, potomogeton, hydrophila) } \\
\text { Microinvertebrate (adult mayflies) }\end{array}$ & $\begin{array}{l}1 \\
1\end{array}$ & $\begin{array}{l}1 \\
1\end{array}$ & & $\begin{array}{l}0 \\
1\end{array}$ & & $\begin{array}{l}1 \\
1\end{array}$ & $\begin{array}{l}1 \\
1\end{array}$ & $\begin{array}{l}\text { gamma, Sr-90, Tc-99, U-isotopic, Tot-U, Metals } \\
\text { Tot-U, Metals }\end{array}$ \\
\hline Macroinvertebrate (Asian clams - soft tissue) ${ }^{(b)}$ & $5^{(\mathrm{c}, \mathrm{d})}$ & $9^{(\mathrm{c}, \mathrm{d}, \mathrm{e})}$ & $1^{(\mathrm{c})}$ & $9^{(\mathrm{c}, \mathrm{d}, \mathrm{e})}$ & $1^{(\mathrm{c})}$ & $4^{(\mathrm{c}, \mathrm{d})}$ & $4^{(\mathrm{c}, \mathrm{d})}$ & Tot-U, Metals \\
\hline Macroinvertebrate (Asian clams -shell) & $5^{(\mathrm{c}, \mathrm{d})}$ & $9^{(\mathrm{c}, \mathrm{d}, \mathrm{e})}$ & $1^{(\mathrm{c})}$ & $9^{(\mathrm{c}, \mathrm{d}, \mathrm{e})}$ & $1^{(c)}$ & $4^{(\mathrm{c}, \mathrm{d})}$ & $4^{(\mathrm{c}, \mathrm{d})}$ & Tot-U, Metals \\
\hline Macroinvertebrate (crayfish - offal) ${ }^{(a)}$ & 1 & 1 & & 1 & & 1 & 1 & gamma, Sr-90, Tc-99 \\
\hline Macroinvertebrate (crayfish - hepatopancreas) & 5 & 5 & & 4 & & 5 & 5 & Tot-U, Metals \\
\hline $\begin{array}{l}\text { Fish (sculpin - offal) } \\
\text { Fish (sculpin - liver) } \\
\text { Fish (sculpin - bone) }\end{array}$ & $\begin{array}{l}1 \\
5 \\
5\end{array}$ & $\begin{array}{l}1 \\
5 \\
5\end{array}$ & & $\begin{array}{l}0 \\
0 \\
0\end{array}$ & & $\begin{array}{l}1 \\
1 \\
1\end{array}$ & $\begin{array}{l}1 \\
5 \\
5\end{array}$ & $\begin{array}{l}\text { gamma, Sr-90, Tc-99 } \\
\text { Tot-U, Metals } \\
\text { Tot-U }\end{array}$ \\
\hline \multicolumn{9}{|c|}{$\begin{array}{l}\text { (a) One composite of all organisms collected at each site. } \\
\text { (b) Whole organisms without shell. } \\
\text { (c) Each sample was comprised of } 2 \text { to } 5 \text { individual organisms. } \\
\text { (d) Samples were collected along a transect set perpendicular to shoreline beginning at seep or shoreline at fixed depths }(0.0,0.25,0.5,1.0 \text {, and } 1.5 \text { meters). } \\
\text { (e) Includes } 4 \text { results from } 1 \text { transect located immediately downstream of the seep. } \\
\text { (f) Maximum value was reported from near-shore sample sites (within } 5 \text { meters of shoreline and in water } 0.5 \text { meter depth or less). }\end{array}$} \\
\hline
\end{tabular}

Concentrations of tritium, strontium-90, technetium-99, and cesium-137 were elevated in one or more biota samples at the 300 Area shoreline study sites (Locations 7, 9, 11, and 14).

Riparian Community Surveillance. Radiological results were obtained for clover, mulberry, and mice. Not all species were collected in all sampling areas. Technetium-99 was measured in mulberry at concentrations roughly an order of magnitude higher than that observed in clover. In the mulberry leaves, concentrations were nearly six times greater at Location $9(6.54 \pm 0.5 \mathrm{pCi} / \mathrm{g}$ wet wt. $)$ compared to the upstream reference site (less than detection: $0.15 \mathrm{pCi} / \mathrm{g}$ wet wt.) and Locations 7 and 14 . Technetium-99 in the mulberry leaf sample from Location 11 was elevated, but at only one-half of the level reported for Location 9 (Table 4.2).

Table 4.2. Concentrations of Technetium-99 in Selected Biota $(\mu \mathrm{g} / \mathrm{g}$ dry wt., minimum detection $<0.15$ pCi/g dry wt.)

\begin{tabular}{|c|c|c|c|c|c|c|c|c|c|c|c|c|c|c|c|}
\hline Biota Media & Result & $\begin{array}{r}\text { Vernita } \\
(+/-2 \mathrm{SD}) \\
\end{array}$ & $\begin{array}{c}\# \\
\text { samples } \\
\end{array}$ & Result & $\begin{array}{l}\text { Location } 7 \\
(+/-2 \mathrm{SD}) \\
\end{array}$ & $\begin{array}{c}\# \\
\text { samples } \\
\end{array}$ & Result & $\begin{array}{l}\text { Location } 9 \\
(+/-2 \mathrm{SD}) \\
\end{array}$ & $\begin{array}{c}\# \\
\text { samples } \\
\end{array}$ & Result & $\begin{array}{l}\text { Location } 1 \\
(+/-2 \mathrm{SD}) \\
\end{array}$ & $\begin{array}{c}1 \\
\# \\
\text { samples } \\
\end{array}$ & Result & $\begin{array}{l}\text { Location } 1 \\
(+/-2 \mathrm{SD}) \\
\end{array}$ & $\begin{array}{c}4 \\
\quad \# \\
\text { samples }\end{array}$ \\
\hline $\begin{array}{l}\text { RIPARIAN COMMUNITY } \\
\text { Riparian Perrenial Vegetation } \\
\text { (sweet clover) }\end{array}$ & -0.02 & 0.14 & 1 & 0.20 & 0.15 & 1 & 0.33 & 0.15 & 1 & 0.32 & 0.15 & 1 & 0.20 & 0.15 & 1 \\
\hline Riparian Tree (mulberry leaves) & -0.01 & 0.14 & 1 & 0.77 & 0.17 & 1 & 6.54 & 0.47 & 1 & 3.46 & 0.31 & 1 & 0.18 & 0.15 & 1 \\
\hline Small Mammal ${ }^{\star}$ (mouse) & NA & NA & 0 & 0.01 & 0.14 & 1 & NA & NA & 0 & -0.03 & 0.14 & 1 & -0.02 & 0.14 & 1 \\
\hline \multicolumn{16}{|l|}{ AQUATIC COMMUNITY } \\
\hline Macrophytes (millfoil) & 0.09 & 0.14 & 1 & 0.22 & 0.15 & 1 & NA & NA & 0 & 0.31 & 0.15 & 1 & 0.04 & 0.14 & 1 \\
\hline Macroinvertebrates ${ }^{\star}$ (crayfish) & 0.00 & 0.13 & 1 & 0.03 & 0.14 & 1 & 0.12 & 0.14 & 1 & 0.09 & 0.14 & 1 & 0.03 & 0.14 & 1 \\
\hline Predatory Fish ${ }^{\star}$ (sculpin) & -0.02 & 0.13 & 1 & 0.10 & 0.34 & 1 & NA & NA & 0 & 0.04 & 0.14 & 1 & -0.04 & 0.13 & 1 \\
\hline
\end{tabular}

NA $=$ Not applicable.

$\mathrm{SD}=$ Standard deviation. 
Elevated tritium concentrations (relative to the Vernita Site) were observed in both sweet clover and mulberry leaf samples. As was observed with technetium-99, mulberry leaf sample concentrations exceed clover sample concentrations by nearly an order of magnitude. The differences in tritium and technetium-99 concentrations between the two riparian species may reflect the deeper rooting distance of mulberry trees compared to clover.

Strontium-90 was not observed in mulberry leaf samples at the 300 Area or Vernita site, but was marginally detected at Vernita in clover samples. Cesium-137 concentrations were close to detection levels in clover. The maximum concentrations of cesium-137 approached $0.3 \mathrm{pCi} / \mathrm{g}$ dry wt. at Locations 9 and 11.

The composite samples of mice included the entire carcass without the liver and kidney. Neither technetium-99 nor cesium-137 were observed in composited mouse samples. No mice were collected at the Vernita sample site or Location 9.

Aquatic Community Surveillance. Radiological results were obtained for Asian clam, crayfish, sculpin, and macrophytes. The composite samples of crayfish and sculpin included the entire carcass without the hepatopancreas or liver.

Neither strontium-90, technetium-99, or cesium-137 were at observed in composited scuplin samples collected at Vernita and Locations 7, 11 and 14. Moreover, technetium-99 and cesium-137 were not observed in any crayfish composite samples. Strontium- 90 was observed in composited crayfish samples at all sampling sites. The two highest concentrations were observed in samples from Vernita and Location 14, suggesting that Hanford-derived strontium-90 is not entering the shoreline environment along the 300 Area.

No aquatic macrophytes were collected at Location 9; samples from Vernita and Locations 7, 11, and 14 had strontium-90 concentrations close to the limit of detection with no discernable pattern of accumulation with respect to 300 Area shoreline springs. Similarly, technetium-99 was observed in low concentrations at Locations 7 and 11, and was below detection at Vernita and Location 14.

\subsubsection{Chemicals in Biota}

Concentrations of arsenic, beryllium, chromium, selenium, zinc, and uranium were elevated in one or more biota samples at the 300 Area shoreline study sites (Locations 7, 9, 11, and 14). Concentrations of aluminum, antimony, cadmium, copper, lead, manganese, mercury, nickel, silver, and thorium were frequently detected in the biota samples at the Vernita Bridge background locations and the results were similar to those reported in biota samples collected along the 300 Area shoreline (Appendix C, Table C.5). Cadmium, lead, and manganese concentrations appeared elevated in more than one organism at the Vernita reference site compared to the 300 Area. In addition, silver concentrations in crayfish at the Vernita Bridge reference site were generally twice as high as the 300 Area results.

\section{Riparian Community Surveillance}

Arsenic. Arsenic was not dramatically elevated in the riparian environment along the 300 Area. Arsenic concentrations were similar in samples of mouse, sweet clover, and mulberry leaves at the study 
locations where samples were collected. The maximum concentrations of arsenic in the perennial vegetation (sweet clover) and trees were found at the Vernita site (Table 4.3). Single composite samples of darkling beetles at Locations 7 and 14 were an order of magnitude higher in arsenic $(1.15$ versus $0.1 \mu \mathrm{g} / \mathrm{g}$ dry wt.) than the reference site or Locations 9 and 11. The darkling beetle results are difficult to interpret because the spatial distribution of arsenic in soil is not well characterized and in the early years, arsenicbased pesticides may have been used in or near the study area.

Table 4.3. Concentrations of Arsenic in Selected Biota ( $\mu \mathrm{g} / \mathrm{g}$ dry wt., minimum detection $<0.1 \mu \mathrm{g} / \mathrm{g}$ dry wt.)

\begin{tabular}{|c|c|c|c|c|c|c|c|c|c|c|c|c|c|c|c|}
\hline Biota Media & median & $\begin{array}{l}\text { Vernita } \\
\text { maximum }\end{array}$ & $\begin{array}{c}\# \\
\# \\
\text { samples } \\
\end{array}$ & median & $\begin{array}{c}\text { Location } 7 \\
\text { maximim } \\
\end{array}$ & $\begin{array}{c}\# \\
\text { samples } \\
\end{array}$ & median & $\begin{array}{l}\text { Location } 9 \\
\text { maximum }\end{array}$ & \# samples & median & $\begin{array}{l}\text { Location } 11 \\
\text { maximum }\end{array}$ & $\begin{array}{c}\# \\
\text { samples } \\
\end{array}$ & median & $\begin{array}{l}\text { Location } 14 \\
\text { maximum }\end{array}$ & $\begin{array}{c}\# \\
\text { samples } \\
\end{array}$ \\
\hline RIPARIAN COMMUNITY & & & & & & & & & & & & & & & \\
\hline $\begin{array}{l}\text { Riparian Perennial Vegetation (sweet } \\
\text { clover) }\end{array}$ & 1.33 & 1.33 & 1 & 1.17 & 1.17 & 1 & 0.38 & 0.38 & 1 & 0.10 & 0.10 & 1 & 0.10 & 0.10 & 1 \\
\hline Riparian Tree (mulberry leaves) & 1.54 & 1.54 & 1 & 0.47 & 0.47 & 1 & 0.45 & 0.45 & 1 & 0.10 & 0.10 & 1 & 0.10 & 0.10 & 1 \\
\hline Invertebrates (darkling beetles) & 0.10 & 0.10 & 1 & 1.14 & 1.14 & 1 & 0.10 & 0.10 & 1 & 0.10 & 0.10 & 1 & 1.15 & 1.15 & 1 \\
\hline Mouse (liver) & $N A^{(a)}$ & NA & 0 & 1.14 & 1.48 & 3 & NA & NA & 0 & 1.33 & 1.55 & 4 & 1.02 & 1.02 & 2 \\
\hline AQUATIC COMMUNITY & & & & & & & & & & & & & & & \\
\hline Periphyton (algae/diatoms) & NA & NA & 0 & NA & NA & 0 & 6.96 & 6.96 & 1 & 10.75 & 10.80 & 2 & 10.60 & 10.60 & 1 \\
\hline Macrophytes (millfoil) & 6.91 & 6.91 & 1 & 6.83 & 6.83 & 1 & NA & NA & 0 & 3.60 & 3.60 & 1 & 4.75 & 4.75 & 1 \\
\hline Invertebrates (adult mayflies) & 0.10 & 0.10 & 1 & 1.02 & 1.02 & 1 & NA & NA & 0 & 0.10 & 0.10 & 1 & 0.10 & 0.10 & 1 \\
\hline Clams (soft tissue) ${ }^{(\mathrm{b})}$ & 13.10 & 13.40 & $5^{(\mathrm{c}, \mathrm{d})}$ & 11.60 & $17.9^{(e, f)}$ & $9^{(c, d)}$ & 11.70 & $19.1^{(e, f)}$ & $9^{(c, d)}$ & 10.95 & 12.20 & $4^{(\mathrm{c}, \mathrm{d})}$ & 12.25 & 16.2 & $4^{(\mathrm{c}, \mathrm{d})}$ \\
\hline Clams (shell) & 0.10 & $1.45^{(f)}$ & $5^{(\mathrm{c}, \mathrm{d})}$ & 0.19 & $2.25^{(\mathrm{e})}$ & $9^{(\mathrm{c}, \mathrm{d})}$ & 0.10 & $0.186^{(e, f)}$ & $9^{(\mathrm{c}, \mathrm{d})}$ & 0.11 & $0.166^{(f)}$ & $4^{(\mathrm{c}, \mathrm{d})}$ & 0.21 & $1.21^{(f)}$ & $4^{(\mathrm{c}, \mathrm{d})}$ \\
\hline Crayfish (hepatopancreas) & 7.50 & 12.20 & 5 & 5.56 & 9.55 & 5 & 7.43 & 13.10 & 4 & 7.03 & 11.80 & 5 & 6.24 & 9.13 & 5 \\
\hline Sculpin (liver) & 2.65 & 4.11 & 5 & 4.12 & 11.50 & 5 & NA & NA & 0 & 9.01 & 9.01 & 1 & 4.28 & 12.30 & 5 \\
\hline $\begin{array}{l}\text { (a) NA = Not avaliable/not analyzed. } \\
\text { (b) Whole organisms without shell. } \\
\text { (c) Each sample comprised of } 2 \text { to } 5 \text { in } \\
\text { (d) Samples were collected along a tra } \\
\text { (e) Includes } 4 \text { results from } 1 \text { transect } \\
\text { (f) }\end{array}$ & tual & $\begin{array}{l}\text { sms. } \\
\text { endice }\end{array}$ & & 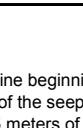 & 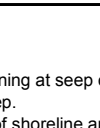 & 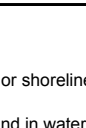 & five & s. & $(0.0,0.2$ & 1.0 & $1.5 \mathrm{met}$ & & & & \\
\hline
\end{tabular}

Beryllium. Beryllium was not detected in any terrestrial biota collected in the riparian environments (Table 4.4).

Chromium. In the riparian environment, sweet clover from Location 11 was the only organism with an elevated concentration of chromium compared to the Vernita location (Table 4.5).

Selenium. In the riparian environment, one small mammal sample collected at Location 11 had a selenium concentration $(6.2 \mu \mathrm{g} / \mathrm{g}$ dry wt. $)$ that was ten times higher than any other reported in this study $(0.57 \mu \mathrm{g} / \mathrm{g}$ dry wt. $)$. Otherwise, there was little evidence of elevated selenium within the riparian zone (Table 4.6).

Uranium. Elevated uranium (compared to the background site) was measured in the riparian environment at Location 7 and this was one of only two occasions in this study where contaminants were distinctly elevated in the riparian ecosystem (Table 4.7). Concentrations of uranium in the biota from the 300 Area had the largest difference between values from the background results of all contaminants examined in this study. Samples of perennial vegetation (sweet clover), and mulberry leaves at Locations 7, 9, and 11, had elevated levels of uranium compared to the Vernita Bridge background location. Sweet clover accumulated $\sim 10$ times more uranium at Location 7 than at any other site. Mulberry leaf samples contained about 8 to 10 times more uranium at Locations 7 and 9 than samples collected at other 
locations. The deeper rooting zone of mulberry trees likely accounts for the higher concentrations compared to clover. Two of the three mice collected at Location 7 were above the minimum detection limit $(0.01 \mu \mathrm{g} / \mathrm{g}$ dry wt. $)$ as compared to zero of six samples above minimum detection collected at Locations 11, and 14. Mice trapping at Vernita was unsuccessful.

Table 4.4. Concentrations of Beryllium in Selected Biota ( $\mu \mathrm{g} / \mathrm{g}$ dry wt., minimum detection $<0.1 \mu \mathrm{g} / \mathrm{g}$ dry wt.)

\begin{tabular}{|c|c|c|c|c|c|c|c|c|c|c|c|c|c|c|c|}
\hline Biota Media & median & $\begin{array}{c}\text { Vernita } \\
\text { maximum }\end{array}$ & $\begin{array}{c}\# \\
\text { samples } \\
\end{array}$ & median & $\begin{array}{l}\text { Location } 7 \\
\text { maximim } \\
\end{array}$ & $\begin{array}{c}\# \\
\text { samples } \\
\end{array}$ & median & $\begin{array}{l}\text { Location } 9 \\
\text { maximum }\end{array}$ & $\begin{array}{c}\# \\
\text { samples } \\
\end{array}$ & median & $\begin{array}{l}\text { Location } 1 \\
\text { maximum }\end{array}$ & $\begin{array}{ccc}1 & & \# \\
& & \\
& \text { samples } \\
\end{array}$ & median & $\begin{array}{l}\text { Location \# } \\
\text { maximum }\end{array}$ & $\begin{array}{cc}4 & \\
& \# \\
\text { samples } \\
\end{array}$ \\
\hline \multicolumn{16}{|l|}{ RIPARIAN COMMUNITY } \\
\hline $\begin{array}{l}\text { Riparian Perennial Vegetation } \\
\text { (sweet clover) }\end{array}$ & 0.04 & 0.04 & 1 & 0.04 & 0.04 & 1 & 0.04 & 0.04 & 1 & 0.04 & 0.04 & 1 & 0.04 & 0.04 & 1 \\
\hline Riparian Tree (mulberry leaves) & 0.04 & 0.04 & 1 & 0.04 & 0.04 & 1 & 0.04 & 0.04 & 1 & 0.04 & 0.04 & 1 & 0.04 & 0.04 & 1 \\
\hline Invertebrates (darkling beetles) & 0.04 & 0.04 & 1 & 0.04 & 0.04 & 1 & 0.04 & 0.04 & 1 & 0.04 & 0.04 & 1 & 0.04 & 0.04 & 1 \\
\hline Mouse (liver) & $N A^{(a)}$ & NA & 0 & 0.05 & 0.05 & 3 & NA & NA & 0 & 0.05 & 0.05 & 4 & 0.05 & 0.05 & 2 \\
\hline \multicolumn{16}{|l|}{ AQUATIC COMMUNITY } \\
\hline Periphyton (algae/diatoms) & NA & NA & 0 & NA & NA & 0 & 0.15 & 0.15 & 1 & 0.26 & 0.26 & 1 & 0.21 & 0.21 & 1 \\
\hline Macrophytes (millfoil) & 0.04 & 0.04 & 1 & 0.08 & 0.08 & 1 & NA & NA & 0 & 0.04 & 0.04 & 1 & 0.08 & 0.08 & 1 \\
\hline Invertebrates (adult mayflies) & 0.04 & 0.04 & 1 & 0.04 & 0.04 & 1 & NA & NA & 0 & 0.04 & 0.04 & 1 & 0.04 & 0.04 & 1 \\
\hline Clams (soft tissue) ${ }^{(\mathbf{b})}$ & 0.05 & 0.12 & $5^{(c, d)}$ & 0.05 & $0.208^{(e, f)}$ & $9^{(\mathrm{c}, \mathrm{d})}$ & 0.05 & $0.09^{(e, f)}$ & $9^{\text {cd }}$ & 0.05 & 0.05 & $4^{(\mathrm{c}, \mathrm{d})}$ & 0.05 & $0.0501^{(f)}$ & $4^{(\mathrm{c}, \mathrm{d})}$ \\
\hline Clams (shell) & 0.04 & 0.04 & $5^{(\mathrm{c}, \mathrm{d})}$ & 0.04 & $0.04^{(\mathrm{e})}$ & $9^{(\mathrm{c}, \mathrm{d})}$ & 0.04 & $0.04^{(e)}$ & $9^{\text {cd }}$ & 0.04 & 0.04 & $4^{(\mathrm{c}, \mathrm{d})}$ & 0.04 & 0.04 & $4^{(\mathrm{c}, \mathrm{d})}$ \\
\hline Crayfish (hepatopancreas) & 0.05 & 0.05 & 5 & 0.05 & 0.05 & 5 & 0.05 & 0.05 & 4 & 0.05 & 0.05 & 5 & 0.05 & 0.05 & 5 \\
\hline Sculpin (liver) & 0.33 & 0.50 & 5 & 0.35 & 1.42 & 5 & NA & NA & 0 & 0.05 & 0.05 & 1 & 0.05 & 0.05 & 5 \\
\hline
\end{tabular}

(a) NA = Not avaliable/not analyzed.

(b) Whole organisms without shell.

(c) Each sample comprised of 2 to 5 individual organisms.

(d) Samples were collected along a transect set perpendicular to shoreline beginning at seep or shoreline at fixed water depths $(0.0,0.25,0.5,1.0$, and 1.5 meters)

(e) Includes 4 results from 1 transect located immediately downstream of the seep.

(f) Maximum value was reported from near-shore sample sites (within 5 meters of shoreline and in water 0.5 meter depth or less).

Table 4.5. Concentrations of Chromium in Selected Biota $(\mu \mathrm{g} / \mathrm{g}$ dry wt., minimum detection $<0.1 \mu \mathrm{g} / \mathrm{g}$ dry wt.)

\begin{tabular}{|c|c|c|c|c|c|c|c|c|c|c|c|c|c|c|c|}
\hline Biota Media & median & $\begin{array}{c}\text { Vernita } \\
\text { maximum }\end{array}$ & $\begin{array}{c}\# \\
\text { samples } \\
\end{array}$ & median & $\begin{array}{l}\text { Location } 7 \\
\text { maximim }\end{array}$ & $\begin{array}{c}\# \\
\text { samples } \\
\end{array}$ & median & $\begin{array}{l}\text { Location } 9 \\
\text { maximum }\end{array}$ & $\begin{array}{c}\# \\
\text { samples } \\
\end{array}$ & median & $\begin{array}{l}\text { Location } 1 \\
\text { maximum }\end{array}$ & $\begin{array}{cc}1 & \\
\text { samples } \\
\end{array}$ & median & $\begin{array}{l}\text { Location } 14 \\
\text { maximum }\end{array}$ & $\begin{array}{c}\# \\
\text { samples } \\
\end{array}$ \\
\hline $\begin{array}{l}\text { RIPARIAN COMMUNITY } \\
\text { Riparian Perennial Vegetation } \\
\text { (sweet clover) }\end{array}$ & 0.97 & 0.97 & 1 & 0.76 & 0.76 & 1 & 1.01 & 1.01 & 1 & 1.24 & 1.24 & 1 & 0.33 & 0.33 & 1 \\
\hline Riparian Tree (mulberry leaves) & 1.07 & 1.07 & 1 & 0.99 & 0.99 & 1 & 1.03 & 1.03 & 1 & 0.63 & 0.63 & 1 & 0.44 & 0.44 & 1 \\
\hline Invertebrates (darkling beetles) & 1.92 & 1.92 & 1 & 1.27 & 1.27 & 1 & 0.99 & 0.99 & 1 & 1.77 & 1.77 & 1 & 1.70 & 1.70 & 1 \\
\hline Mouse (liver) & $N A^{(a)}$ & NA & 0 & 0.43 & 0.50 & 3 & NA & NA & 0 & 0.35 & 0.58 & 4 & 0.67 & 0.82 & 2 \\
\hline \multicolumn{16}{|l|}{ AQUATIC COMMUNITY } \\
\hline Periphyton (algae/diatoms) & NA & NA & 0 & NA & NA & 0 & 13.50 & 13.50 & 1 & 24.60 & 24.60 & 1 & 21.60 & 21.60 & 1 \\
\hline Macrophytes (millfoil) & 3.52 & 3.52 & 1 & 6.70 & 6.70 & 1 & NA & NA & 0 & 3.60 & 3.60 & 1 & 5.69 & 5.69 & 1 \\
\hline Invertebrates (adult mayflies) & 7.35 & 7.35 & 1 & 2.30 & 2.30 & 1 & NA & NA & 0 & 0.37 & 0.37 & 1 & 2.86 & 2.86 & 1 \\
\hline Clams (soft tissue) ${ }^{(b)}$ & 1.35 & $2.99^{(f)}$ & $5^{(\mathrm{c}, \mathrm{d})}$ & 3.60 & $9.20^{(e, f)}$ & $9^{(\mathrm{c}, \mathrm{d})}$ & 2.84 & $11.30^{(\mathrm{e}, \mathrm{f})}$ & $9^{(\mathrm{c}, \mathrm{d})}$ & 1.70 & $2.37^{(\text {() }}$ & $4^{(\mathrm{c}, \mathrm{d})}$ & 1.98 & 3.44 & $4^{(\mathrm{c}, \mathrm{d})}$ \\
\hline Clams (shell) & 0.10 & $0.243^{(f)}$ & $5^{(\mathrm{c}, \mathrm{d})}$ & 0.15 & $0.35^{(e)}$ & $9^{(\mathrm{c}, \mathrm{d})}$ & 0.29 & $43.20^{(e, f)}$ & $9^{(\mathrm{c}, \mathrm{d})}$ & 0.26 & $0.28^{(f)}$ & $4^{(\mathrm{c}, \mathrm{d})}$ & 0.11 & 0.17 & $4^{(\mathrm{c}, \mathrm{d})}$ \\
\hline Crayfish (hepatopancreas) & 0.65 & 0.91 & 5 & 0.55 & 0.66 & 5 & 0.71 & 0.82 & 4 & 0.79 & 1.11 & 5 & 0.63 & 0.65 & 5 \\
\hline Sculpin (liver) & 0.01 & 0.16 & 5 & 0.01 & 3.81 & 5 & NA & NA & 0 & 1.40 & 1.40 & 1 & 0.40 & 2.25 & 5 \\
\hline
\end{tabular}

(a) NA = Not avaliable/not analyzed.

(b) Whole organisms without shell.

(c) Each sample comprised of 2 to 5 individual organisms.

(d) Samples were collected along a transect set perpendicular to shoreline beginning at seep or shoreline at fixed water depths $(0.0,0.25,0.5,1.0$, and 1.5 meters).

(e) Includes 4 results from 1 transect located immediately downstream of the seep.

(f) Maximum value was reported from near-shore sample sites (within 5 meters of shoreline and in water 0.5 meter depth or less). 
Table 4.6. Concentrations of Selenium in Selected Biota $(\mu \mathrm{g} / \mathrm{g}$ dry wt., minimum detection $<0.2$ to $0.6 \mu \mathrm{g} / \mathrm{g}$ dry wt.)

\begin{tabular}{|c|c|c|c|c|c|c|c|c|c|c|c|c|c|c|c|}
\hline Biota Media & median & $\begin{array}{c}\text { Vernita } \\
\text { maximum }\end{array}$ & $\begin{array}{c}\# \\
\text { samples } \\
\end{array}$ & median & $\begin{array}{l}\text { Location } 7 \\
\text { maximim }\end{array}$ & $\begin{array}{c}\# \\
\text { samples } \\
\end{array}$ & median & $\begin{array}{l}\text { Location } 9 \\
\text { maximum }\end{array}$ & \# samples & median & $\begin{array}{l}\text { Location } 11 \\
\text { maximum } \\
\end{array}$ & $\begin{array}{c}\# \\
\text { samples } \\
\end{array}$ & median & $\begin{array}{l}\text { Location } 14 \\
\text { maximum } \\
\end{array}$ & $\begin{array}{c}\# \\
\text { samples } \\
\end{array}$ \\
\hline \multicolumn{16}{|l|}{ RIPARIAN COMMUNITY } \\
\hline $\begin{array}{l}\text { Riparian Perennial Vegetation (sweet } \\
\text { clover) }\end{array}$ & 2.15 & 2.15 & 1 & 2.28 & 2.28 & 1 & 0.20 & 0.20 & 1 & 0.20 & 0.20 & 1 & 0.20 & 0.20 & 1 \\
\hline Riparian Tree (mulberry leaves) & 3.22 & 3.22 & 1 & 0.20 & 0.20 & 1 & 0.82 & 0.82 & 1 & 0.20 & 0.20 & 1 & 0.20 & 0.20 & 1 \\
\hline Invertebrates (darkling beetles) & 0.20 & 0.20 & 1 & 0.20 & 0.20 & 1 & 0.20 & 0.20 & 1 & 0.20 & 0.20 & 1 & 0.20 & 0.20 & 1 \\
\hline Mouse (liver) & $\mathrm{NA}^{(\mathrm{a})}$ & NA & 0 & 0.57 & 0.57 & 3 & NA & NA & 0 & 0.57 & 6.22 & 4 & 0.57 & 0.57 & 2 \\
\hline \multicolumn{16}{|l|}{ AQUATIC COMMUNITY } \\
\hline Periphyton (algae/diatoms) & NA & NA & 0 & NA & NA & 0 & 0.20 & 0.20 & 1 & 0.45 & 0.71 & 2 & 0.20 & 0.20 & 1 \\
\hline Macrophytes (millfoil) & 0.20 & 0.20 & 1 & 3.58 & 3.58 & 1 & NA & NA & 0 & 0.20 & 0.20 & 1 & 0.59 & 0.59 & 1 \\
\hline Invertebrates (adult mayflies) & 0.20 & 0.20 & 1 & 1.32 & 1.32 & 1 & NA & NA & 0 & 0.20 & 0.20 & 1 & 0.20 & 0.20 & 1 \\
\hline Clams (soft tissue) ${ }^{(b)}$ & 0.57 & 0.57 & $5^{(\mathrm{c}, \mathrm{d})}$ & 0.79 & $3.1^{(e, f)}$ & $9^{(c, d)}$ & 0.60 & $3.0^{(e, f)}$ & $9^{(c, d)}$ & 1.47 & $1.73^{(f)}$ & $4^{(c, d)}$ & 0.57 & 1.51 & $4^{(c, d)}$ \\
\hline Clams (shell) & 0.20 & 0.20 & $5^{(\mathrm{c}, \mathrm{d})}$ & 0.20 & $0.51^{(e, f)}$ & $9^{(0, d)}$ & 0.34 & $1.16^{(e, f)}$ & $9^{(c, d)}$ & 0.20 & $0.423^{(t)}$ & $4^{(c, d)}$ & 0.20 & $0.471^{(t)}$ & $4^{(\mathrm{c}, \mathrm{d})}$ \\
\hline Crayfish (hepatopancreas) & 0.57 & 0.57 & 5 & 0.57 & 0.57 & 5 & 0.60 & 0.60 & 4 & 0.57 & 0.57 & 5 & 0.57 & 0.57 & 5 \\
\hline Sculpin (liver) & 0.57 & 0.57 & 5 & 0.57 & 0.57 & 5 & 0.60 & 0.60 & 0 & 0.57 & 0.57 & 1 & 0.57 & 0.57 & 5 \\
\hline $\begin{array}{l}\text { (a) NA = Sample not available. } \\
\text { (b) Whole organisms without shell. } \\
\text { (c) Each sample comprised of } 2 \text { to } 5 \text { ir } \\
\text { (d) Samples were collected along a tra } \\
\text { (e) Includes } 4 \text { results from } 1 \text { transect I } \\
\text { (f) Maximum value was reported from }\end{array}$ & $\begin{array}{l}\text { dual o } \\
\text { ct set } \\
\text { ed imr }\end{array}$ & $\begin{array}{l}\text { isms. } \\
\text { endicul } \\
\text { ately dc }\end{array}$ & - & e se & t see & & fixe & er depths & $(0.0,0$ & $.5,1$. & d $1.5 n$ & & & & \\
\hline
\end{tabular}

Table 4.7. Concentrations of Uranium in Selected Biota $(\mu \mathrm{g} / \mathrm{g}$ dry wt., minimum detection $<0.1 \mu \mathrm{g} / \mathrm{g}$ dry wt.)

\begin{tabular}{|c|c|c|c|c|c|c|c|c|c|c|c|c|c|c|c|}
\hline Biota Media & median & $\begin{array}{c}\text { Vernita } \\
\text { maximum }\end{array}$ & $\begin{array}{c}\# \\
\text { samples } \\
\end{array}$ & median & $\begin{array}{l}\text { Location } 7 \\
\text { maximim }\end{array}$ & $\begin{array}{cc}7 & \# \\
\text { samples } \\
\end{array}$ & median & $\begin{array}{l}\text { Location } 9 \\
\text { maximum }\end{array}$ & $\begin{array}{c}\# \\
\text { samples } \\
\end{array}$ & median & $\begin{array}{l}\text { Location } 11 \\
\text { maximum }\end{array}$ & $\begin{array}{cc}1 & \# \\
\text { samples } & \\
\end{array}$ & median & $\begin{array}{l}\text { Location } 1 \\
\text { maximum }\end{array}$ & $\begin{array}{c}14 \\
\quad \# \\
\text { samples }\end{array}$ \\
\hline $\begin{array}{l}\text { RIPARIAN COMMUNITY } \\
\text { Riparian Perennial Vegetation (sweet } \\
\text { clover) }\end{array}$ & 0.01 & 0.01 & 1 & 0.12 & 0.12 & 1 & 0.03 & 0.03 & 1 & 0.05 & 0.05 & 1 & 0.01 & 0.01 & 1 \\
\hline Riparian Tree (mulberry leaves) & 0.01 & 0.01 & 1 & 0.08 & 0.08 & 1 & 0.12 & 0.12 & 1 & 0.02 & 0.02 & 1 & 0.01 & 0.01 & 1 \\
\hline Invertebrates (darkling beetles) & 0.13 & 0.13 & 1 & 0.16 & 0.16 & 1 & 0.04 & 0.04 & 1 & 0.12 & 0.12 & 1 & 0.03 & 0.03 & 1 \\
\hline Mouse (kidney) & $N A^{(a)}$ & NA & 1 & 0.01 & 0.02 & 3 & NA & NA & 0 & 0.01 & 0.04 & 4 & 0.01 & 0.01 & 2 \\
\hline Mouse (liver) & NA & NA & 0 & 0.01 & 0.01 & 3 & NA & NA & 0 & 0.01 & 0.01 & 4 & 0.01 & 0.01 & 2 \\
\hline Mouse (skin) & NA & NA & 0 & 0.02 & 0.04 & 3 & NA & NA & 0 & 0.01 & 0.01 & 4 & 0.01 & 0.01 & 2 \\
\hline \multicolumn{16}{|l|}{ AQUATIC COMMUNITY } \\
\hline Periphyton (algae/diatoms) & NA & NA & 0 & NA & NA & 0 & 3.66 & 3.66 & 1 & 10.70 & 10.70 & 1 & 3.60 & 3.60 & 1 \\
\hline Macrophytes (millfoil) & 1.91 & 1.91 & 1 & 9.29 & 9.29 & 1 & NA & NA & 0 & 7.71 & 7.71 & 1 & 6.31 & 6.31 & 1 \\
\hline Invertebrates (adult mayflies) & 2.34 & 2.34 & 1 & 3.06 & 3.06 & 1 & NA & NA & 0 & 7.14 & 7.14 & 1 & 1.20 & 1.20 & 1 \\
\hline Clams (soft tissue) ${ }^{(b)}$ & 0.20 & $0.42^{(1)}$ & $5^{5^{(\mathrm{c}, d)}}$ & 1.63 & $4.31^{(\mathrm{e}, \mathrm{f})}$ & $9^{(\mathrm{c}, \mathrm{d})}$ & 2.85 & $6.77^{(e, f)}$ & $9^{(c, d)}$ & 1.39 & $1.95^{(f)}$ & $4^{(\mathrm{c}, \mathrm{d})}$ & 0.16 & $0.22^{(i)}$ & $4^{(0, d)}$ \\
\hline Clams (shell) & 0.07 & $0.11^{(f)}$ & $5^{(\mathrm{c}, \mathrm{d})}$ & 0.91 & $2.32^{(\mathrm{e}, f)}$ & $9^{(\mathrm{c}, \mathrm{d})}$ & 4.23 & $11.20^{(e, f)}$ & $9^{(c, d)}$ & 0.80 & 1.70 & $4^{(\mathrm{c}, \mathrm{d})}$ & 0.06 & $0.10^{(f)}$ & $4^{(\mathrm{c}, \mathrm{d})}$ \\
\hline Crayfish (hepatopancreas) & 0.47 & 0.68 & 5 & 1.28 & 2.21 & 5 & 3.33 & 6.29 & 4 & 2.99 & 7.81 & 5 & 0.33 & 0.71 & 5 \\
\hline Sculpin (liver) & 0.01 & 0.03 & 5 & 0.03 & 0.05 & 5 & NA & NA & 0 & 0.01 & 0.01 & 1 & 0.02 & 0.02 & 5 \\
\hline Sculpin (bone) & 0.08 & 0.12 & 5 & 0.13 & 0.33 & 5 & NA & NA & 0 & 0.06 & 0.06 & 1 & 0.05 & 0.10 & 5 \\
\hline \multicolumn{16}{|l|}{$\begin{array}{l}\text { (a) NA = Not avaliable/not analyzed. } \\
\text { (b) Whole organisms without shell. }\end{array}$} \\
\hline
\end{tabular}

Zinc. Concentrations of zinc in biota results indicate there were fairly similar between the 300 Area and the background study location, with an indication of slightly elevated levels of zinc at the 300 Area near shore (Table 4.8). The highest concentration of zinc was measured in mulberry leaves from the Vernita reference site. 
Table 4.8. Concentrations of Zinc in Selected Biota $(\mu \mathrm{g} / \mathrm{g}$ dry wt., minimum detection $<0.1 \mu \mathrm{g} / \mathrm{g}$ dry wt.)

\begin{tabular}{|c|c|c|c|c|c|c|c|c|c|c|c|c|c|c|c|}
\hline Biota Media & median & $\begin{array}{l}\text { Vernita } \\
\text { maximum }\end{array}$ & $\begin{array}{c}\# \\
\text { samples }\end{array}$ & median & $\begin{array}{l}\text { Location } 7 \\
\text { maximim }\end{array}$ & $\begin{array}{c}\# \\
\text { samples } \\
\end{array}$ & median & $\begin{array}{l}\text { Location } 9 \\
\text { maximum }\end{array}$ & $\begin{array}{c}\# \\
\text { samples } \\
\end{array}$ & median & $\begin{array}{l}\text { Location } 11 \\
\text { maximum }\end{array}$ & $\begin{array}{cc}1 & \\
\text { samples } \\
\end{array}$ & median & $\begin{array}{l}\text { Location } 14 \\
\text { maximum }\end{array}$ & $\begin{array}{cc}4 & \\
\text { samples } \\
\end{array}$ \\
\hline $\begin{array}{l}\text { RIPARIAN COMMUNITY } \\
\text { Riparian Perennial Vegetation } \\
\text { (sweet clover) }\end{array}$ & 20.00 & 20.00 & 1 & 18.20 & 18.20 & 1 & 24.80 & 24.80 & 1 & 22.20 & 22.20 & 1 & 23.20 & 23.20 & 1 \\
\hline Riparian Tree (mulberry leaves) & 36.80 & 36.80 & 1 & 14.90 & 14.90 & 1 & 18.20 & 18.20 & 1 & 14.90 & 14.90 & 1 & 31.60 & 31.60 & 1 \\
\hline Invertebrates (darkling beetles) & 67.90 & 67.90 & 1 & 71.00 & 71.00 & 1 & 112.00 & 112.00 & 1 & 79.80 & 79.80 & 1 & 56.20 & 56.20 & 1 \\
\hline Mouse (liver) & $N A^{(a)}$ & NA & 0 & 86.80 & 118.00 & 3 & NA & NA & 0 & 82.60 & 112.00 & 4 & 92.05 & 101.00 & 2 \\
\hline AQUATIC COMMUNITY & & & & & & & & & & & & & & & \\
\hline Periphyton (algae/diatoms) & NA & NA & 0 & NA & NA & 0 & 104.00 & 104.00 & 1 & 173.00 & 173.00 & 1 & 174.00 & 174.00 & 1 \\
\hline Macrophytes (millfoil) & 168.00 & 168.00 & 1 & 138.00 & 138.00 & 1 & NA & NA & 0 & 135.00 & 135.00 & 1 & 185.00 & 185.00 & 1 \\
\hline Invertebrates (adult mayflies) & 169.00 & 169.00 & 1 & 104.00 & 104.00 & 1 & NA & NA & 0 & 67.00 & 67.00 & 1 & 81.30 & 81.30 & 1 \\
\hline Clams (soft tissue) $)^{(b)}$ & 111.00 & 150.00 & $5^{(c, d)}$ & 131.00 & $181.00^{(\mathrm{e})}$ & $9^{(\mathrm{c}, \mathrm{d})}$ & 120.00 & $153.00^{(\mathrm{e})}$ & $9^{(\mathrm{c}, \mathrm{d})}$ & 98.10 & $122.00^{(f)}$ & $4^{(\mathrm{c}, \mathrm{d})}$ & 98.40 & $106.00^{(f)}$ & $4^{(\mathrm{c}, \mathrm{d})}$ \\
\hline Clams (shell) & 5.36 & $23.70^{f}$ & $5^{(\mathrm{c}, \mathrm{d})}$ & 4.79 & $7.58^{(\mathrm{e})}$ & $9^{(\mathrm{c}, \mathrm{d})}$ & 6.12 & $10.30^{(\mathrm{e})}$ & $9^{(\mathrm{c}, \mathrm{d})}$ & 7.29 & $9.96^{(\mathfrak{f})}$ & $4^{(\mathrm{c}, \mathrm{d})}$ & 3.23 & 5.38 & $4^{(\mathrm{c}, \mathrm{d})}$ \\
\hline Crayfish (hepatopancreas) & 229.00 & 462.00 & 5 & 105.00 & 127.00 & 5 & 175.00 & 274.00 & 4 & 108.00 & 471.00 & 5 & 206.00 & 301.00 & 5 \\
\hline Sculpin (liver) & 111.00 & 214.00 & 5 & 188.00 & 291.00 & 5 & NA & NA & 0 & 252.00 & 252.00 & 1 & 363.00 & 463.00 & 5 \\
\hline \multicolumn{16}{|c|}{ (a) NA = Not avaliable/not analyzed. } \\
\hline \multicolumn{16}{|c|}{$\begin{array}{l}\text { (b) Whole organisms without shell. } \\
\text { (c) Each sample comprised of } 2 \text { to } 5 \text { individual organisms. }\end{array}$} \\
\hline $\begin{array}{l}\text { (d) Samples were collected alon } \\
\text { (e) Includes } 4 \text { results from } 1 \text { tran }\end{array}$ & transect & set perpend & dicular t & reline & inning & ep o & reline & xed wa & epth & $0,0.25$ & $5,1.0$ & $.5 \mathrm{~m}$ & & & \\
\hline
\end{tabular}

\section{Aquatic Community Surveillance}

Arsenic. In the aquatic environment, arsenic levels in clams from the Vernita Bridge location ranged between 8.8 and $13.4 \mu \mathrm{g} / \mathrm{g}$ dry wt., whereas 7 of $18 \mathrm{clam}$ soft tissue samples collected from Locations 7 and 9 were reported between 13.0 and $19.1 \mu \mathrm{g} / \mathrm{g}$ dry wt. The four maximum tissue residue levels (16.4 to $19.1 \mu \mathrm{g} / \mathrm{g}$ dry wt.) found in clam soft tissue (whole organisms without shell) were collected from Locations 7, $7 \mathrm{DR}, 9$, and $9 \mathrm{DR}$ within a depth of 0.25 meter from the riverbank spring ( 0 to 4 meters from shoreline). Arsenic concentrations in the composite sample of adult mayflies was one order of magnitude greater at Location 7 compared to the upriver reference, Location 11, and Location 14 (1.02 verses $0.1 \mu \mathrm{g} / \mathrm{g}$ dry wt.). Differences in arsenic levels between sample sites were not apparent in milfoil, crayfish, or sculpin samples.

Beryllium. Detectable levels of beryllium were found in samples of periphyton, sculpin liver, and soft tissue of clams but they did not have a pattern that would support discharges from shoreline springs. Periphyton was not found at the upstream reference site so a comparison with background samples was not possible. Sculpin liver contained detectable levels of beryllium at Vernita and at Location 7, compared to Locations 11 and 14 where it was below the detection limit. The maximum concentration in sculpin was at Location 7 (1.42 $\mu \mathrm{g} / \mathrm{g}$ dry wt.) and was approximately three times as high as the maximum result from the upstream reference site $(0.5 \mu \mathrm{g} / \mathrm{g}$ dry wt.), although the median values at these sites were similar. Beryllium was not appreciably elevated in clams (soft tissue or shells) collected along the 300 Area shoreline, but the single maximum value $(0.21 \mu \mathrm{g} / \mathrm{g}$ dry wt.) was reported from a depth of 0.25 meter ( $\sim 4$ meters out from shoreline) at Location 7 and was nearly twice as high as the maximum result reported from the upstream reference site $(0.12 \mu \mathrm{g} / \mathrm{g}$ dry wt.).

Chromium. Chromium results from the aquatic community samples revealed that mayflies at Vernita Bridge had the highest concentration $(7.35 \mu \mathrm{g} / \mathrm{g}$ dry wt.), but results for macrophytes, clam (soft and 
shell), and sculpin samples identified Locations 7, 9, 11 as having 3 to 4 times higher concentrations than the upstream reference site. Soft tissue of clams measured at these sites and midpoints between Locations 7 and 9 and Locations 9 and 11 had dramatically lower concentrations that the samples from the active riverbank spring discharge areas at Locations 7 and 9 (Figure 4.15). The maximum concentrations were found in samples collected from near the active riverbank springs (within 4 meters of the shoreline) and well-defined peaks were apparent in samples from a depth of 0.5 meter ( 2 to 10 meters from shore). Although results still appeared slightly elevated in clams collected at the deepest sample points examined at Locations 7 and 9 ( $\sim 15$ meters out from the shorelines), the values were similar to the highest reported result from the upstream reference site $(2.99 \mu \mathrm{g} / \mathrm{g}$ dry wt. $)$.

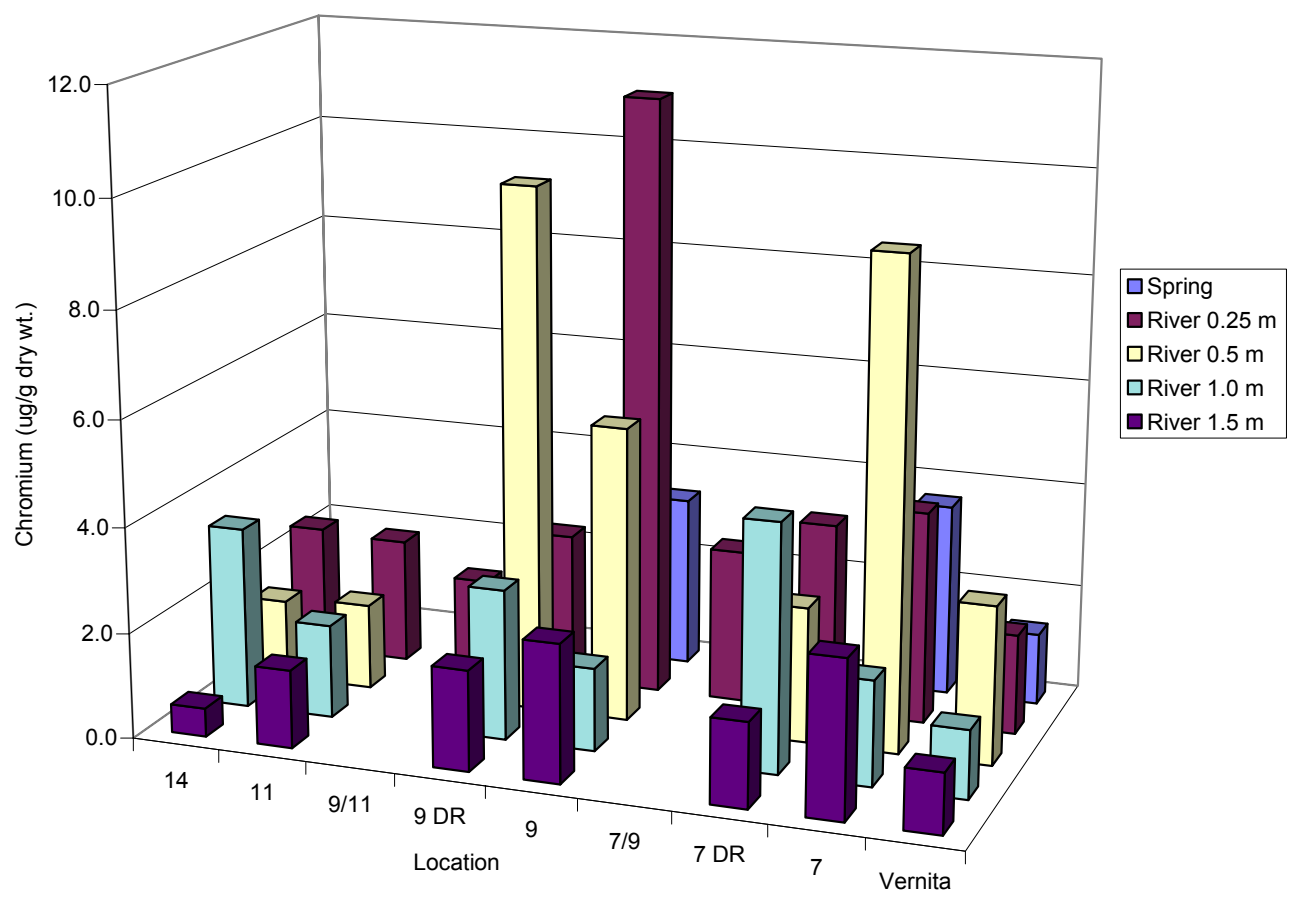

Figure 4.15. Chromium in Soft Tissues of Asian Clams

Estimate of Spatial Extent of Chromium Influence. Clams were sampled along transects at the active riverbank spring discharges (Locations 7 and 9), at locations downriver from the riverbank springs discharges (Locations $7 \mathrm{DR}$ and $9 \mathrm{DR}$ ), and at two near-shore locations between the primary sampling sites (Locations 7/9 and 9/11). Location 7 DR was 130 meters downstream from Location 7 and Location 9 DR was 65 meters downstream from Location 9 (Table 4.9). Elevated chromium concentrations were apparent at both Location 7 DR and Location 9 DR (see Figure 4.15), but the results from the nearshore samples collected at Location 7/9 and Location 9/11 were lower than the upstream results which were closer to the active riverbank springs. An area extending 15 meters into the river channel (gradual sloping banks) by 210 meters of shoreline length and enclosing roughly 3,150 square meters would approximate the spatial extent of the Location 7 benthic communities that contain three to four times more chromium (attributable to 300 Area groundwater contamination) than upstream reference samples. At Location 9 , an area $\sim 5$ meters into the river channel (steep river banks) by 100 meters of shoreline 
length enclosing roughly 500 square meters of benthic community would be a roughly estimate the area where benthic communities have accumulated three to four times more chromium from riverbank springs and groundwater upwelling.

Table 4.9. Distances Between Shoreline Locations and Perpendicular Distances from the Shoreline for 300 Area Biota Sample Transects

\begin{tabular}{|c|c|c|c|c|c|c|}
\hline \multirow[b]{2}{*}{ Location } & \multicolumn{2}{|c|}{ Distance Between Locations } & \multicolumn{4}{|c|}{ Distance from Shoreline ${ }^{(a)}$} \\
\hline & \multicolumn{2}{|c|}{ Shoreline (0.0 m depth) } & (0.25 m depth) & (0.5 $\mathrm{m}$ depth) & (1.0 m depth) & (1.5 $\mathrm{m}$ depth) \\
\hline$\overline{77}$ & \multicolumn{2}{|c|}{ 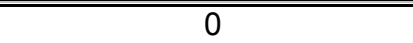 } & 3.48 & 9.4 & 12.0 & 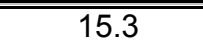 \\
\hline $7 \mathrm{DR}$ & 7 to $7 \mathrm{DR}$ & $130 \mathrm{~m}$ & $<0.5 \mathrm{~m}$ & 2.1 & 7.6 & 9.9 \\
\hline $7 / 9$ & 7 DR to $7 / 9$ & $210 \mathrm{~m}$ & $<0.5 \mathrm{~m}$ & & & \\
\hline 9 & $7 / 9$ to 9 & $165 \mathrm{~m}$ & 1.6 & 4.6 & 9.8 & 15.6 \\
\hline $9 \mathrm{DR}$ & 9 to 9 DR & $65 \mathrm{~m}$ & $<0.5 \mathrm{~m}$ & 1.8 & 8.5 & 12.9 \\
\hline $9 / 11$ & 9 DR to $9 / 11$ & $245 \mathrm{~m}$ & $<0.5 \mathrm{~m}$ & & & \\
\hline 11 & $9 / 11$ to 11 & $275 \mathrm{~m}$ & $<0.5 \mathrm{~m}$ & 2.0 & 3.2 & 6.3 \\
\hline 14 & 11 to 14 & $1,305 \mathrm{~m}$ & $<0.5 \mathrm{~m}$ & 2.8 & 3.6 & 6.8 \\
\hline
\end{tabular}

(a) Perpendicular distance (meters $+/-1 \mathrm{~m}$ ) from shoreline at $\sim 40,000$ CFS discharge from Priest Rapids Dam.

Selenium. Selenium concentrations reported for the aquatic community were elevated for mayflies, macrophytes, and clam (soft tissue and shell) at Locations 7, 9, and 11. A single macrophyte sample and a single composite sample of adult mayflies collected from Location 7 had selenium concentrations that were six to ten times higher than results reported from other sites. Figure 4.16 illustrates the accumulation of selenium in soft tissue of clams collected from each sampling location. The highest selenium levels occurred in the benthic community along downriver Location 7 DR and continued at relatively high levels ( 1.0 to $4.1 \mu \mathrm{g} / \mathrm{g}$ dry wt.) downstream to the sampling location between Locations 7 and 9 and to Location 9. Results for selenium in clam tissues from downriver Location 9 DR was not different from upstream reference results but elevated levels were reported at the sampling point between Locations 9 and 11, at Location 11, and also marginally at Location 14.

Estimate of Spatial Extent of Selenium. Elevated selenium concentrations in clams samples collected along Location 7 DR extended to the deepest sample point, $\sim 9.9$ meters out into the river. Elevated concentrations also were reported at Location 7/9 and at Location 9 extended to the sample point at a depth of 1 meter, $\sim 9.8$ meters out from the shoreline. Location 7 DR was $\sim 210$ meters upstream of Location 7/9, which was 165 meters upstream of Location 9. An area extending roughly 10 meters into the river channel by 570 meters of shoreline and enclosing about 5,700 square meters would approximate the spatial extent between Location 7 and Location 9 DR, where the benthic communities contained five to ten times more selenium (attributable to the discharge of groundwater into the river) than upstream reference samples. Elevated levels of selenium were also detected at Location 9/11 and at Location 11 but not to the extent found at Location $7 \mathrm{DR}$ and Location 9. Unfortunately, downriver transect samples were not collected at Location 9/11 or at Location 11, thus an estimate of the spatial extent of elevated selenium levels was not possible there. 


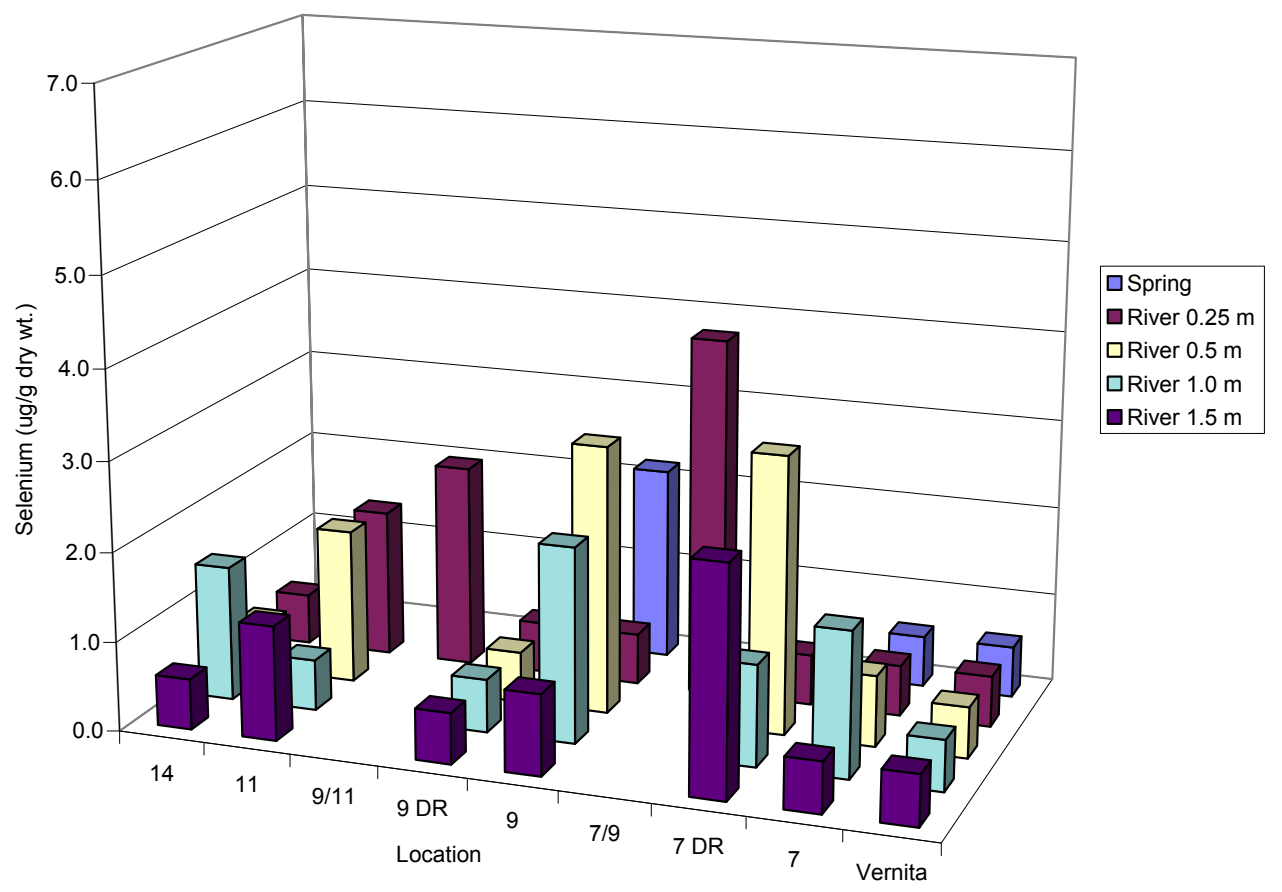

Figure 4.16. Selenium in Soft Tissues of Asian Clams

Uranium. Elevated uranium concentrations were measured in the aquatic community at Locations 7 , 9, 11, and to a lesser degree at Location 14 , the farthest downstream study site (1,305 meters downstream from Location 11; Figure 4.17). Uranium was detected in all aquatic biota measured at the upstream reference site, with sculpin liver found to generally contain the least amount of uranium (generally at or near the analytical detection limit of $0.01 \mu \mathrm{g} / \mathrm{g}$ dry wt.). Since uranium typically accumulates in kidney and bone tissues, a sample of sculpin bone was analyzed specifically for comparison of uranium results between individuals and sites. These results were consistently above analytical detection limits and were about 2 to 3 times higher at Location 7 (see Table 4.7) compared to the other locations.

The highest uranium concentrations were generally seen in lower trophic-level systems (macrophytic non-native plant - milfoil, periphyton (algae/diatoms), and adult mayflies. However, these biota were represented (when present) with a single composite sample of hundreds of individuals that were found as close to the riverbank spring locations as possible. Multiple samples of clam-soft tissue, clamshell, and crayfish hepatopancreas collected from each study site contained elevated concentrations of uranium at Locations 7, 9, and 11 (see Figure 4.17). The highest concentrations measured in soft tissues of clams were found at Locations 7 and 9 were $\sim 10$ to 20 times greater than maximum results reported from upstream reference samples. Concentrations in clamshells generally mimicked the uranium pattern and concentrations reported in the soft-tissues. The only noticeable differences were higher levels found at Locations $7 \mathrm{DR}$ and $9 \mathrm{DR}$ at the deepest transect points (a depth of 1.5 meters). Crayfish hepatopancreas also accumulated uranium at Locations 7, 9, and 11 at levels 3 to 10 times the levels reported in the upstream reference samples. The highest median and maximum crayfish hepatopancreas concentrations 
were found at Locations 9 and 11 (as opposed to Locations 7 and 9 for clams) (see Table 4.7) and were nearly twice as high as those concentrations reported in crayfish hepatopancreas from Location 7 (Appendix C, Table C.5).

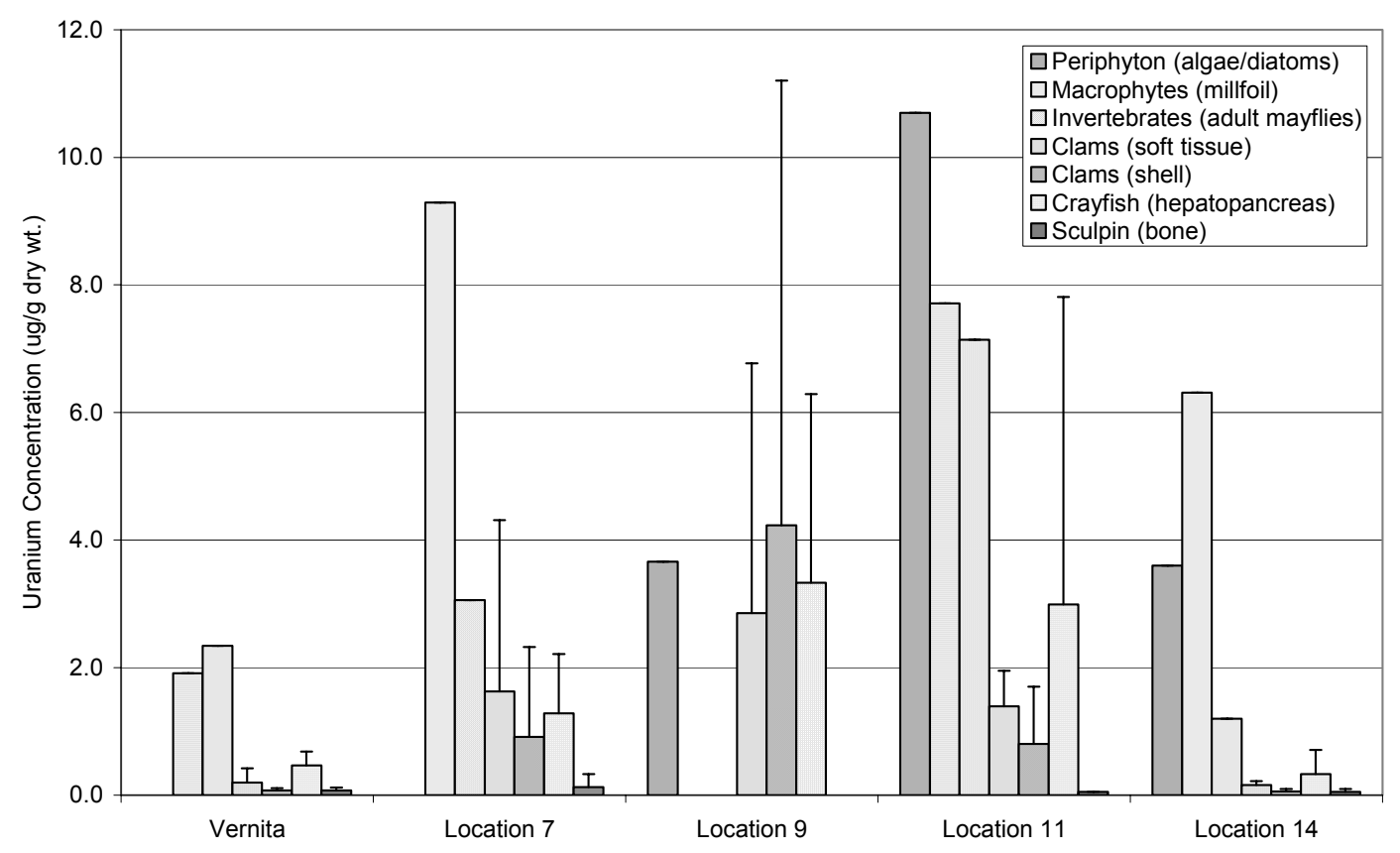

Figure 4.17. Uranium Concentrations in Selected Biota

Estimate of Spatial Extent of Uranium Influence. Figure 4.18 depicts the accumulation of uranium in soft tissue (whole body) of clam samples comprised of 2 to 5 individuals per sample point. Uranium concentrations at Locations 7, 9, and 11 appeared to reach peak concentrations not at the shoreline where the riverbank spring discharge entered, but at 0.25 meter river water depth ( 0.5 to 4 meters out from the shoreline). Uranium levels steadily diminished further out into the river (at perpendicular shoreline distances of 3 to 12 meters). However, elevated concentrations (approximately twice that of reference results) were still apparent at the deepest transect points measured at Locations 7, 9, 9 DR, and 11 (6 to 16 meters from the shoreline). An area extending $\sim 10$ meters into the river channel and along the shoreline between Locations 7 and 11 ( 1,090 meters of shoreline), coarsely bounds the area (10,900 square meters) where uranium concentrations in clams were twice that of the reference location. For the 130 meters of shoreline between Locations 7 and 7 DR, the area where uranium concentrations in clams were 10 to 20 times that of background extended to the river depth of 0.5 meter ( 2 to 10 meters from shore) and encompassed $\sim 780$ square meters. For the 65 meters of shoreline between Locations 9 and $9 \mathrm{DR}$, the area where uranium concentrations in clams were 10 to 20 times that of background extended to the river depth of 0.5 meter ( 5 meters into the channel) at Location 9 and the river depth of 1 meter at downriver Location 9 DR (8.5 meters into the channel) and encompassed $\sim 40$ square meters. 


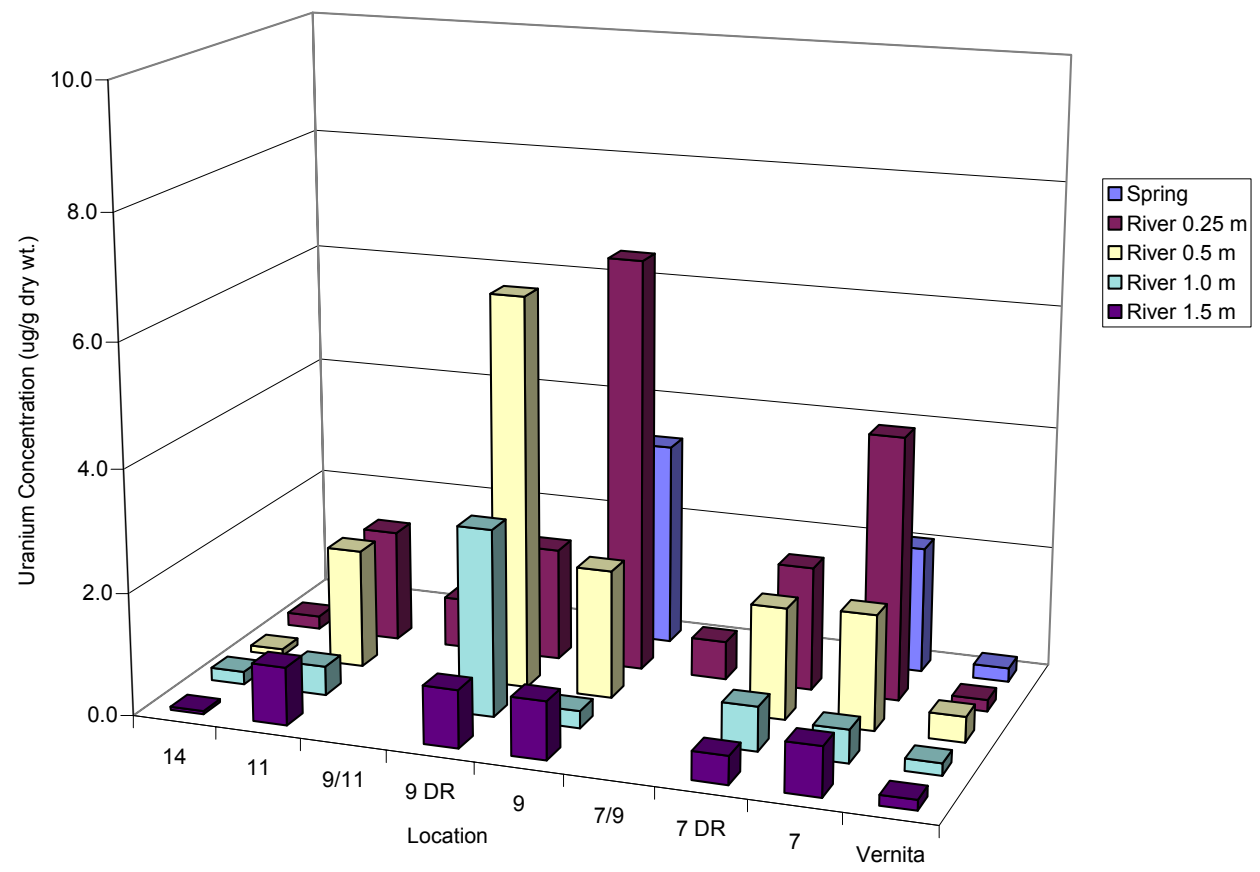

Figure 4.18. Uranium in Soft Tissues of Asian Clams

Zinc. The maximum concentrations of zinc were found in macrophytes, adult mayflies, and crayfish hepatopancreas from the upstream reference site (see Table 4.8). Elevated levels in biota were also observed at Location 14, but were similar to those values observed at the upstream reference site. Three of five sculpin liver samples collected from Location 14 were 2 to 3 times greater than the upstream reference values and were the highest values reported for sculpin samples $(n=16)$. Unfortunately, the desired numbers of sculpin were not collected at two of the 300 Area sites (one site only consisted of a single individual) and this prevented statistical comparisons between locations. The soft tissue samples of clams were slightly elevated at Location 7 with a median and maximum zinc concentration of 131 and $181 \mu \mathrm{g} / \mathrm{g}$ dry wt., respectively, compared to the upstream reference site median and maximum of 111 and $150 \mu \mathrm{g} / \mathrm{g}$ dry wt.

\subsubsection{Inspection of Individual-Level Health of Selected Biota Types}

An investigation of ecological effects resulting from contaminants at particular sites of concern should include an examination of a variety of measurable biological endpoints that can be related to individual-level survival rates and potential population-level impact. Natural variations in physical, biological, and chemical conditions have to be characterized to predict the presence and abundance of selected biological indicator species at the sites of concern. Easily said, in practice, the most important species (i.e., the largest total biological masses present in the system or the top predator species) are often too heterogeneous in nature or rare at the sites of concern to make any reasonable interpretation of biological impact. 
A cursory inspection was conducted of those species that possess life-history characteristics that best fit the "ideal" biological indicator species of healthy ecosystems (Rosenberg and Resh 1993). Target organs (i.e., known to accumulate and/or to be adversely affected by excessive levels of the contaminants in their environment) were sampled from all mice, crayfish, and sculpin collected during this study and submitted for necropsy and histopathological analysis of injuries. Basic morphological measurements also were recorded for each animal and maintained in a database for each individual sampled. Samples of bone, muscle, liver, kidneys, gonads, and lung or gill were collected from each small mammal and sculpin and were prepared individually for interpretation. For crayfish, samples of the hepatopancreas (the toxinfiltering organ of a crayfish), exoskeleton, muscle, gonads, eggs or sperm, gills, and any anomalous tissues encountered during the tissue dissection and sample preparation process. The small total number of samples collected (see Table 4.1) of each species at each location prevented statistical comparisons of animal injury rates. However, the data provided some insight into the level of effort necessary for a more comprehensive characterization study of biological health at these sites.

The majority of sample tissues lacked significant lesions. Two of four mice samples collected at Location 7 had indications of bacterial or viral infections, but no microbes were seen. No other lesions were reported in mice tissues. Mice were not collected successfully at the upstream reference site, so no comparison of injury rates was possible.

Four to five crayfish were collected at each of the sampling sites in this study, and 22 of 24 individuals examined for histology had essentially normal tissues. One crayfish collected from Location 9 and one from Location 11 had mild inflammation of the gills. Although no particular causative agent was identified, infection or poor water quality could have contributed to this damage, but no microbes were seen. Location 11 is at the upper reach of Lake Wallula created by McNary Dam, while the Vernita Bridge site is non-impounded water.

Eight of the 16 sculpin collected and histologically examined (including 5 from the upstream reference site) showed signs of tissue injury. Three individuals from the upstream reference location had granulomas in the testis, necrosis of the gills, and inflammation of the ovaries. These injuries are signs of bacterial or viral infection or poor water quality. Two of five sculpin collected from Location 7 had granulomas in the gill and liver. The single sculpin collected from Location 11 had some non-specific changes associated with irritation of the gill filaments that could be associated with either poor water quality or infection. Two of five sculpins collected at Location 14 had granulomas in the musculature and in the ovary.

These results appear to be random, but the frequency of individual injuries can be summarized by sites or combined-areas to examine the relative injury rates for the selected species. Eighty percent $(n=14)$ of the crayfish examined along the 300 Area shoreline (Locations 7, 9, and 11) had essentially normal tissues with no lesions. This value compares to $100 \%$ of the organisms measured at the upstream reference site $(\mathrm{n}=5)$ and at the study site most downstream ( the upstream reference site $(\mathrm{n}=5)$ were found with no histological lesions, compared to nearly $70 \%$ along the 300 Area $(n=10)$, and $40 \%$ of the organisms measured at the most downstream study site $(n=5)$. 


\subsection{External Radiation}

External radiation measurement data and corresponding GPS coordinate data were analyzed first by reducing the amount of data. This was done by averaging exposure rates and GPS coordinates every 30 seconds for terrestrial measurements and every 15 seconds for the measurements made from the boat. The averaging process eliminated fluctuations in the data due to the uncertainty of measuring a per hour quantity based on per second measurements. The specific averaging time was chosen to optimize the graphical display of the data. The reduced data was plotted on a map, with the radiation intensities color coded, and the data are listed in Appendix B, Tables B.8 to B.11.

The maximum exposure rate measured along the 300 Area shoreline was $10.0 \mu \mathrm{R} / \mathrm{h}$, which corresponds to an annual exposure rate of $88 \mathrm{mR}$ (Figure 4.19). The maximum exposure rate measured at the upstream background location, near Vernita Bridge was $10.2 \mu \mathrm{R} / \mathrm{h}$, which corresponds to an annual exposure rate of $89 \mathrm{mR}$ (Figure 4.20). No significant difference between the two location's maximum and average exposure rate readings can be identified (Table 4.10). External exposure rates on the river are lower than those on the shoreline because the river water shields gamma radiation originating from natural sources in the earth's crust. The 300 Area shoreline results are similar to results of an aerial survey performed in 1988 (Reiman and Dahlstrom 1990). They measured terrestrial external exposure rates of $\sim 8 \mu \mathrm{R} / \mathrm{h}$ around the 300 Area but excluded a cosmic contribution of $3.7 \mu \mathrm{R} / \mathrm{h}$. The current survey performed for this study did not exclude the cosmic contribution. One point of interest concerns the minimum readings, which were lower along the 300 Area shoreline than along the shoreline at the background location (see Table 4.10).

Table 4.10. Normal Statistics for Reduced Exposure Rate Datasets Collected near Vernita Bridge and along the 300 Area Shoreline

\begin{tabular}{||l|c|c|c|c|c||}
\hline \multicolumn{1}{|c|}{ Location } & $\begin{array}{c}\text { Average } \\
\mu \mathrm{R} / \mathrm{h}\end{array}$ & $\begin{array}{c}\text { Maximum } \\
\mu \mathrm{R} / \mathrm{h}\end{array}$ & $\begin{array}{c}\text { Minimum } \\
\mu \mathrm{R} / \mathrm{h}\end{array}$ & $\begin{array}{c}\text { Standard } \\
\text { Deviation }\end{array}$ & $\begin{array}{c}\text { Number of } \\
\text { Readings }\end{array}$ \\
\hline \hline 300 Area Shoreline & 8.5 & 10.0 & 6.8 & 0.63 & 105 \\
\hline 300 Area River & 3.7 & 4.6 & 2.8 & 0.38 & 49 \\
\hline Vernita Shoreline & 8.7 & 10.2 & 7.7 & 0.76 & 17 \\
\hline Vernita River & 3.7 & 5.6 & 2.8 & 0.47 & 95 \\
\hline
\end{tabular}

\subsection{Comparison of Results from Split Samples (analyzed by both Washington State Department of Health and PNNL)}

An important component of this study consisted of split sampling, a process where a sample was collected, split into two separate samples, and each sample was analyzed by the participating organization. The results were then compared to assess the reliability of the data.

In this study, the sample collection and analysis duties were divided between Washington State Department of Health and PNNL. Several of the samples were split and analyzed independently by each agency. This section describes the results of the split sampling effort. 


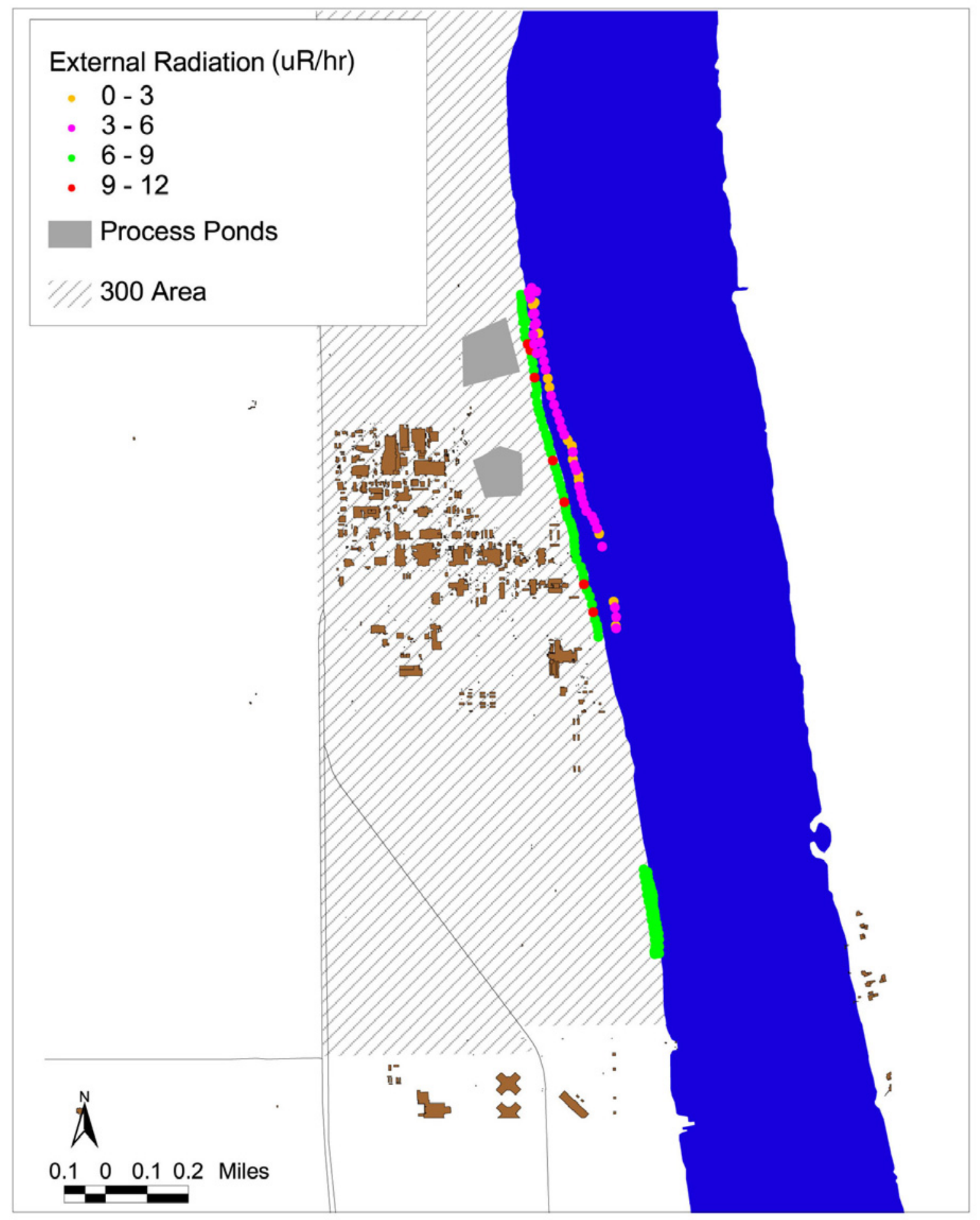

Figure 4.19. External Radiation Measurements at the 300 Area Shoreline 


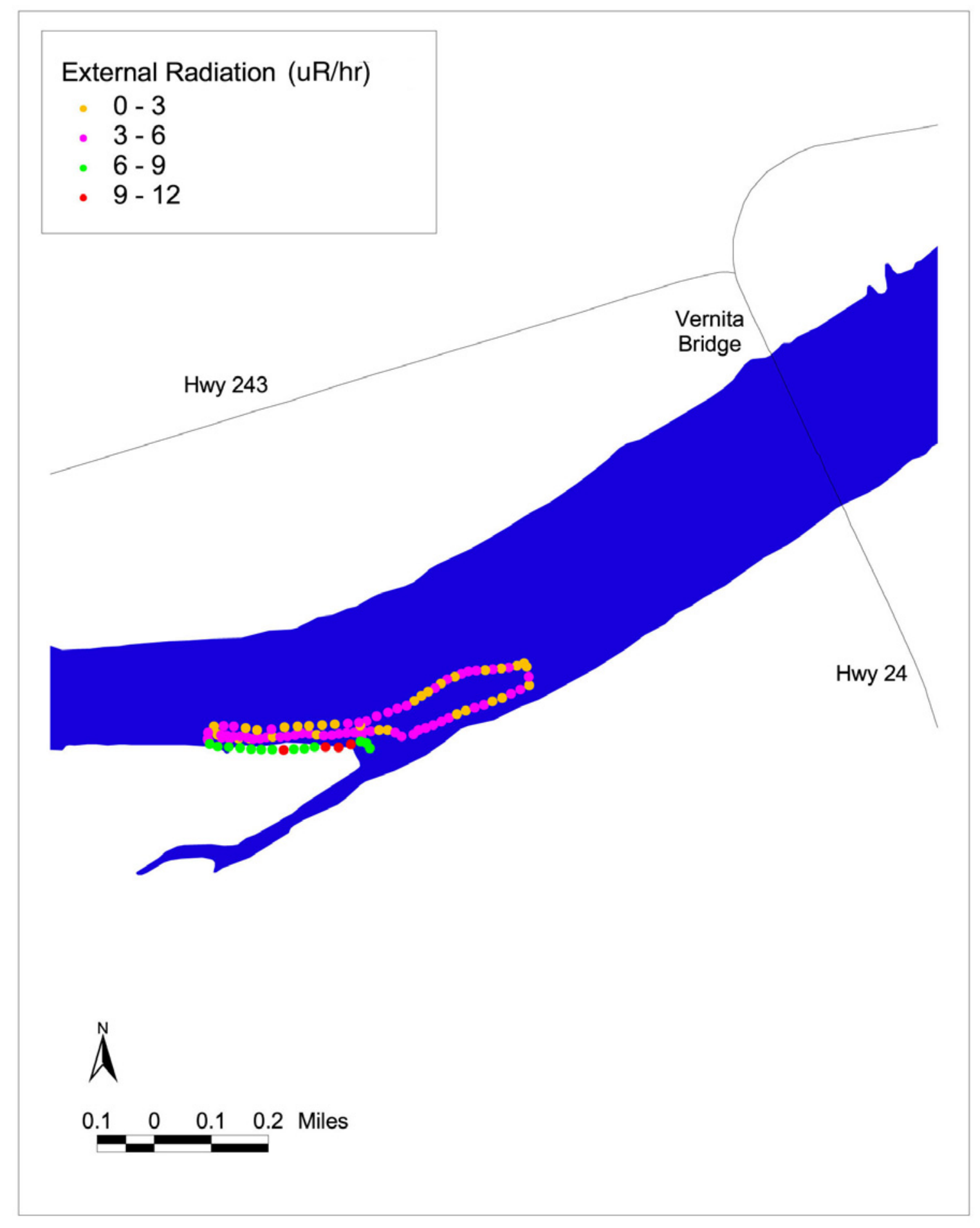

Figure 4.20. External Radiation Measurements near Vernita Bridge 
The split results (Appendix D) consist of the following media and analytes: uranium-234, $-235,-238$, tritium, gross alpha, gross beta, thorium-228, $-230,-232$, and gamma in surface water (riverbank springs and river water); uranium-234, $-235,-238$ and gamma in sediment; and uranium in terrestrial and aquatic vegetation.

The split surface water samples, shown in Appendix D, Figures D.1 to D.7, show excellent agreement between the PNNL and Washington State Department of Health results. Of the 52 analyses, 50 of the reported PNNL and Washington State Department of Health concentrations are in agreement within the 2 -sigma uncertainty. Two of the 52 analyses show slight disagreement. One of the two tritium results, Appendix D, Figure D.3, differed by 10\%; one of the uranium-235 results, Appendix D, Figure D.5, differed by $30 \%$.

The split gamma results in sediment, Appendix D, Figure D.8, are in excellent agreement, while there is some discrepancy in the split uranium results in sediment, Appendix D, Figure D.9. The discrepancy in the uranium results is most likely due to different laboratory techniques used to analyze the samples. Washington State Department of Health dissolves the sediment sample, whereas PNNL uses a leaching technique. Each of these techniques may give rise to different results depending on the nature of the uranium in the sample.

Natural uranium is likely to exist uniformly throughout the volume of the sediment, while uranium from contaminated water is likely to reside on the surface of sediment particles. The sediment at Vernita is most likely natural so that an analysis that dissolves the sample would detect all the uranium throughout the sediment volume while an analysis that leaches the sample would detect only that part of the uranium near the surface. Therefore, the Washington State Department of Health analysis would report a higher concentration than PNNL for a background site. This phenomenon is seen in this study and at numerous other sites where Washington State Department of Health and PNNL split sediment samples. On the other hand, if a sample contains mostly uranium contaminant, residing primarily on the sediment surface, then both analysis methods would yield similar results. This may explain why there is discrepancy between the uranium results at Vernita (background site), while the results at Location 7 (contaminated site) are in agreement (Appendix D, Figure D.8).

The uranium results for mulberry leaves and twigs (Appendix D, Figure D.10) are in good agreement, while there is discrepancy in the uranium results for milfoil (Appendix D, Figure D.11). At the background site near Vernita Bridge, the PNNL milfoil uranium concentrations are approximately twice those reported by Washington State Department of Health, while at Location 7, the Washington State Department of Health concentrations are approximately twice those of PNNL. No explanation has been found for this discrepancy.

In summary, the majority of the split results show excellent agreement between the Washington State Department of Health and PNNL results. The only unexplained discrepancy occurs in uranium results for milfoil, in which case the concentrations differ by a factor of two. The split results show that the data presented in this report is reliable. 


\subsection{Human Dose/Risk Assessment}

The radiological and chemical risk for individuals who spend time on the Columbia River and its shoreline near the Hanford Site 300 Area was estimated using data collected in this study. A discussion of the methods used to assess the current effects to human health from radionuclides is presented in Section 5.1. Radiation doses for several current-use activities typical of this area are discussed in Section 5.2. Also discussed in Section 5.2 is the application of the data from this study to future site-use dose assessments. Section 5.3 summarizes the chemical risk for humans primarily by a comparison to drinking water standards and ambient water quality criteria.

\subsection{Methods to Assess Current Impact to Human Health from Radionuclides}

Currently, the most common uses of the stretch of river adjacent to the 300 Area are recreational boating and fishing. This report therefore assesses radiation exposures to a person pursuing recreational boating and fishing activities near the 300 Area shoreline. The human exposure pathways in this assessment include ingestion of river water and clam meat and exposure to external radiation. Ingestion of riverbank spring water and fish also was considered.

Dose assessments commonly report results as an annual dose. However, this method is highly dependent on the exposure scenario chosen to describe an individual's activities throughout the year. A single or small number of exposure scenarios are rarely able to encompass the activities and lifestyles of all populations who use, or might use in the future, the impacted area. To help eliminate the subjective nature of choosing a particular current site-use scenario, this study utilizes the concept of unit doses.

The unit dose for external radiation is based on a 1-hour exposure to external radiation and is reported in units of $\mathrm{mrem} / \mathrm{hr}$. The unit dose for ingestion of river water is based on ingestion of 1 liter of river water and is reported in units of $\mathrm{mrem} / \mathrm{L}$. The unit dose for ingestion of clam meat is based on ingestion of 1 gram of clam meat and is reported in units of $\mathrm{mrem} / \mathrm{g}$. The unit doses can then be used as the basis for specific exposure scenarios, as discussed in Section 5.2. All the resulting unit doses are reported in Table 5.1, and they represent doses from the maximum measured contaminant concentrations.

The external radiation exposure rates at the 300 Area shoreline and the background site near Vernita Bridge are very similar (see Section 4.4). There is no significant difference in the average external exposure rate between the 300 Area and the Vernita Bridge background site, and the maximum exposure rate on the Columbia River is slightly higher at Vernita Bridge. The data indicate that external exposure at the 300 Area shoreline all comes from background radiation. Therefore, there is no impact to people using the river or shoreline from external radiation originating at the 300 Area. The unit dose for external radiation (300 Area exposure rate - background exposure rate) is $0 \mathrm{mrem} / \mathrm{hr}$. 
Table 5.1. Unit Doses for External Radiation and Consumption Pathways for the 300 Area Near Shore

\begin{tabular}{||l|c|c|c||}
\hline \hline \multicolumn{1}{|c|}{ Media } & Type of Exposure & Unit of Exposure & Unit Dose (mrem) \\
\hline \hline External radiation & External & 1 hour & Zero \\
\hline River water & Ingestion & 1 liter & 0.011 \\
\hline Clam meat & Ingestion & 1 gram & 0.00065 \\
\hline
\end{tabular}

The unit dose from ingesting 1 liter of river water is $0.011 \mathrm{mrem} / \mathrm{L}$. The primary radionuclides contributing to this dose are uranium-234 and -238. Tritium and uranium-235 also have minor contributions. Other radionuclides, such as technetium-99, have negligible contributions to dose at the detected concentrations. This unit dose corresponds to ingesting river water with the maximum contaminant concentrations for tritium and uranium, which were found at Location 9. These concentrations are 4,850, 30.5, 1.14 , and $27.8 \mathrm{pCi} / \mathrm{L}$ for tritium, uranium-234, -235 , and -238 , respectively. Background concentrations at Vernita Bridge were not subtracted from the 300 Area values because they were so small. The ingestion dose was calculated using the dose conversion factors for adults from the International Commission on Radiological Protection (ICRP 1996).

The unit dose from ingesting 1 gram of clam meat is $0.00065 \mathrm{mrem} / \mathrm{g}$. This unit dose corresponds to ingesting clam meat with the maximum contaminant concentration of uranium, which was found at Location 9. The isotopic activity concentrations are 1.86, 0.08 , and $1.80 \mathrm{pCi} / \mathrm{g}$ for uranium-234, -235 , and -238 , respectively. The maximum total uranium concentration measured in clam meat is $6.77 \mu \mathrm{g} / \mathrm{g}$ (see Table 4.7). The mass-based total uranium concentration was then converted to isotopic activity concentrations assuming natural isotopic abundances. Due to the small size of the clam sample, radiological analysis was not carried out for other radionuclides. Background concentrations of clam meat at Vernita Bridge were not subtracted from the 300 Area values because they were so small. Ingestion dose conversion factors came from the International Commission on Radiological Protection (ICRP 1996).

Ingestion of riverbank spring water was also considered for its contribution to human dose, but determined to be an implausible exposure pathway. The springs are actually minute trickles of water flowing through the sand and gravel of the shoreline. Professional judgment leads to the belief that it would be difficult to collect any of this water for drinking and, even if it could be done, the water would likely contain significant amounts of sand and grit. Furthermore, field observations indicate that the riverbank springs are only exposed $\sim 15 \%$ of the year. Therefore, ingesting riverbank spring water is not considered in this human dose assessment.

Ingesting fish caught from the Columbia River at the 300 Area also was considered for its contribution to human dose. Sculpin were collected in this study, and although they are excellent environmental indicators, they are not a primary human food source. The sculpin results are therefore applied to the ecological assessment (Section 6.0) but are not included as part of the human dose assessment.

Most fishing in the Hanford Reach is for adult salmon or steelhead (WDW 1983). Typically, adult salmon and steelhead do not feed during their upstream migration or during spawning (Healey 1991; 
Mahler and Larkin 1954). Therefore, the body burdens of radionuclides from fish caught near the 300 Area likely represent what they were exposed to as they matured in the ocean. In addition, any body burdens of radionuclides in salmon or steelhead associated with feeding from the Hanford Reach is probably due to background contaminants in the Columbia River, since the fish spend little time near the shoreline. Therefore, ingesting fish caught from the Columbia River at the 300 Area was not considered in this human dose assessment. There is some fishing for bass along the 300 Area shoreline. Poston (1994) reviewed the radionuclide concentrations in Hanford Reach fish for the period 1982 to 1992 , including some samples from the 300 Area; however, bass consumption was not included in this assessment due to the lack of recent data.

\subsection{Application to Specific Radionuclide Exposure Scenarios}

A goal of this study was to report data that may be used by others to assess current radiological impacts to various population groups. The contaminant concentrations, external radiation exposure rates, and calculated unit doses reported here may be used to assess doses from specific activities and lifestyles associated with specific population groups. Numerous exposure scenarios are possible. For example, the CERCLA work at the 300 Area generally uses an industrial exposure scenario (i.e., 500 hour of exposure per week, with no consumption of groundwater) to establish cleanup goals (EPA 2001). This study evaluates scenarios specific to the Columbia River shoreline. Three examples, as well as additional information for developing exposure scenarios, are given below.

The first example of a current use exposure scenario considers a person fishing on the Columbia River near the 300 Area. In this example, the person does not go ashore and brings drinking water and food from home. In this case, the only exposure pathway is external radiation. Since the unit dose for external radiation above background is zero, the person's radiation dose above background will be zero. This result is independent of the amount of time spent in the area. The same result applies to a boater who does not go ashore.

The second example considers a boater who is curious about the industrial complex on the bluff. This person comes ashore and spends time along the shoreline. In this example, the boater spends 30 minutes in the area, fills a 1-liter water bottle from the river, and collects clams totaling 225 grams ( 0.5 pound) of clam meat, which the person consumes later. Using the unit doses in Table 5.1, the boater will receive zero dose above background from external radiation, a dose of $0.011 \mathrm{mrem}$ from ingesting river water $(0.011 \mathrm{mrem} / \mathrm{L}$ x 1 liter$)$, and $0.15 \mathrm{mrem}$ from ingesting clam meat $(0.00065 \mathrm{mrem} / \mathrm{g} \mathrm{x} 225$ grams$)$, for a total dose of $0.16 \mathrm{mrem}$. This dose is significantly smaller than the $100 \mathrm{mrem} / \mathrm{year}$ dose limit to offsite individuals from exposure to DOE facilities (DOE Order 5400.5).

The final example considers a scientist collecting environmental samples at the 300 Area shoreline. This example considers that the scientist spends two 8-hour days on the shoreline, and each day consumes 2 liters of water from the river. Using the unit doses from Table 5.1, the scientist will receive zero dose above background from external radiation and $0.044 \mathrm{mrem}$ from ingesting river water $(0.011 \mathrm{mrem} / \mathrm{L} \mathrm{x}$ 4 liters), for a total dose of $0.044 \mathrm{mrem}$. Again, this dose is very small compared to regulatory limits.

Use of the near-shore river water as a primary drinking water source was not considered in these examples. This is because all of the river water samples collected in this study came from areas very near 
the shoreline where the river was less than 2 meters deep. Contaminant concentrations, although elevated near the shore, fell to background values rapidly with increasing river depth. It is not likely that a pump would be installed so close to the shore as to be in the contaminated area of the river. Furthermore, this area of the river is not currently used as a primary drinking water supply. However, for comparison purposes only, consumption of 730 liters ( 2 liters/day drinking water scenario) of the most contaminated river water would lead to a dose of $7.8 \mathrm{mrem} /$ year.

It is common in dose assessment to estimate dose to future users of a site. At the 300 Area, this might include, for example, exposure from contaminated river water used as a drinking water source or used to irrigate crops. However, the data presented in this study are of limited value for conducting future use dose assessments. The data represent a snapshot in time, and it is difficult to estimate river water concentrations in the future since they depend on location and movement of the groundwater plumes and river stage, both of which can change with time.

This study provides data that may be used to estimate doses to individuals involved in specific current use activities at the 300 Area shoreline vicinity. The examples demonstrate that typical current use doses are significantly smaller than regulatory limits. Numerous other exposure scenarios are possible, and the data provided here should prove useful in evaluating exposures based on other activities or lifestyles.

\subsection{Chemical Assessment}

An assessment of the effects to humans from exposure to chemical contaminants from the 300 Area near-shore environment is difficult. Unlike radiological assessment, where small dose contributions from individual radionuclides can be combined into an overall dose, methods to determine exposure to a low concentration mixture of chemical contaminants have not been sufficiently developed. Therefore, this chemical assessment will consist of comparison of the measured values for river water and riverbank spring water to existing drinking water standards and ambient water quality criteria. An assessment of human exposure to chemical contaminants from 300 Area sediment and consumption of biota was not attempted.

All results for river water samples collected at the 300 Area near-shore were below both drinking water standards and ambient water quality criteria for anions and metals, with the exception of one nearshore river water sample (river depth of 0.25 meter) collected in the immediate vicinity of the Location 9 riverbank spring. The uranium concentration for the sample at Location 9 river depth of 0.25 meter was $\sim 2.8$ times the drinking water standard of $30 \mu \mathrm{g} / \mathrm{L}$. However, the spatial extent of river water at this concentration was limited to water in the immediate vicinity of the riverbank spring because the uranium concentration of the subsequent sample at river depth 0.5 meter was less than $12 \%$ of the drinking water standard. River water samples were not analyzed for volatile organic compounds.

For riverbank spring water, all results for the 300 Area samples were below existing drinking water standards and ambient water quality criteria, with the exception of uranium, which exceeded the ambient water quality criteria of $30 \mu \mathrm{g} / \mathrm{L}$. Uranium concentrations in riverbank spring water were $40 \mu \mathrm{g} / \mathrm{L}$ for Location 7 and $140 \mu \mathrm{g} / \mathrm{L}$ at Location 9. At the Vernita Bridge background location, the uranium levels were less than $2 \%$ of the drinking water standard. As mentioned in the preceding paragraph, the spatial 
extent of uranium water concentrations that exceed the drinking water standard was limited to the riverbank springs and the river water in the immediate vicinity of the riverbank springs.

For toxic chemicals, the potential human dose from activities at the 300 Area near-shore is primarily from uranium. Uranium is hazardous as both a radionuclide and as a toxic metal (i.e., chemical hazard). Uranium was above ambient water quality criteria for shallow groundwater samples, riverbank spring water, and Columbia River water in the immediate vicinity of the riverbank springs. However, the spatial extent of the elevated uranium concentration was limited. The human doses from chemical exposure from likely current-use exposures, fishing and boating, are low and not expected to be harmful for people engaged in these activities. 


\subsection{Ecological Dose/Risk Assessment}

Human and ecological dose/risk assessments for radiological and chemical exposure are presented in this section.

\subsection{Methods for Radiological Assessment of Biological Impact}

The U.S. Department of Energy has developed a dose assessment method to screen radionuclide concentrations in water, sediment, or soil against existing or currently proposed biota radiological standards (DOE 2002). The standard for aquatic animals and is $1 \mathrm{rad}$ per day (DOE Order 5400.5). Proposed standards for terrestrial plants is $1 \mathrm{rad}$ per day and the proposed standard for terrestrial animals is $0.1 \mathrm{rad}$ per day (DOE 2002). Media sampled for this analysis are Columbia River water, riverbank spring water, and sediment collected at riverbank spring locations (see Sections 4.1 and 4.2). In this discussion, this method will be referred to as the Biota Dose Assessment Committee (BDAC) method.

Maximum radionuclide concentrations reported for river water, riverbank spring water, and sediment were used for BDAC screening dose assessments with a module identified as the Biota Dose Calculator. The initial screen was based on those samples analyzed by radiochemical techniques. Other BDAC screening calculations was performed based on the uranium results that were obtained by ICP-MS analysis and results from drive point sampling of shallow groundwater (Appendix E). If data was not available for sediment, the sediment concentrations were derived with generic distribution coefficients by the program. Maximum measured and derived concentrations in water and sediment were compared to biota concentrations guides (BCGs) with the Biota Dose Calculator module. The BCG is a steady-state concentration in either water or sediment that would result in a modeled dose rate of $1 \mathrm{rad}$ per day in aquatic organisms or terrestrial plants, or $0.1 \mathrm{rad}$ per day for terrestrial or riparian animals. Dividing the measured water or sediment concentration by the BCG value for each radionuclide generates a fraction. The fractions for each radionuclide from a site are totaled to produce a sum of fractions value. If this sum of fractions exceeds 1.0, that indicates the potential for the dose rate to exceed the screening level dose rates of 1 or $0.1 \mathrm{rad}$ per day. In subsequent analyses, the BDAC method was used for more definitive assessments based on species- and site-specific considerations.

\subsubsection{Results and Discussion}

The total sum of fractions for the water and sediment pathways was 0.55 (Table 6.1). The relative dose contribution from the water pathway was roughly a factor of 10 greater than the sediment pathway. The data entered into the Biota Dose Calculator were the maximum concentrations measured anywhere along the 300 Area shoreline.

This total sum of fraction indicates that by using the maximum sediment and water values, the resulting dose to either aquatic, riparian, or terrestrial organisms was less than the corresponding dose guideline of 1 or $0.1 \mathrm{rad} /$ day. Uranium was the major contributor to radiological dose for both water and sediment pathways. The BDAC results using the maximum concentrations did not exceed the screening value. The screening assessment with the ICP-MS uranium results indicated lower relative dose rate 
(Appendix E). The BDAC screening assessment was also applied to the drive point (shallow groundwater) data. These screening assessments yielded a maximum sum of fractions value of 0.68 , failing to exceed the screening guideline of 1 .

Table 6.1. Initial 300 Area Shoreline Study Screening Assessment based on the Biota Dose Calculator Summation of Partial Fractions

\begin{tabular}{|c|c|c|c|c|c|}
\hline Nuclide & $\begin{array}{c}\text { Water } \mathrm{BCG}^{(\mathrm{a})} \\
(\mathrm{pCi} / \mathrm{L})\end{array}$ & $\begin{array}{c}\text { Water Partial } \\
\text { Fraction }\end{array}$ & $\begin{array}{l}\text { Sediment } \mathrm{BCG}^{(\mathrm{a})} \\
(\mathrm{pCi} / \mathrm{g})\end{array}$ & $\begin{array}{l}\text { Sediment Partial } \\
\text { Fraction }\end{array}$ & $\begin{array}{l}\text { Combined Sum } \\
\text { of Fractions }\end{array}$ \\
\hline $\mathrm{H}-3^{(\mathrm{b})}$ & $2.6 \mathrm{E}+08$ & $3.2 \mathrm{E}-05$ & $3.7 \mathrm{E}+05$ & $2.2 \mathrm{E}-08$ & $3.2 \mathrm{E}-05$ \\
\hline $\mathrm{Sr}-90^{(\mathrm{b})}$ & $2.8 \mathrm{E}+02$ & $7.3 \mathrm{E}-04$ & $5.8 \mathrm{E}+02$ & $1.0 \mathrm{E}-05$ & $7.4 \mathrm{E}-04$ \\
\hline I-129 & $3.8 \mathrm{E}+04$ & $1.0 \mathrm{E}-07$ & $2.9 \mathrm{E}+04$ & $1.4 \mathrm{E}-09$ & $1.1 \mathrm{E}-07$ \\
\hline Th-232 & $3.0 \mathrm{E}+02$ & $2.9 \mathrm{E}-04$ & $1.3 \mathrm{E}+03$ & $4.3 \mathrm{E}-03$ & $4.3 \mathrm{E}-03$ \\
\hline U-234 & $2.0 \mathrm{E}+02$ & $2.6 \mathrm{E}-01$ & $5.3 \mathrm{E}+03$ & $1.9 \mathrm{E}-02$ & $2.8 \mathrm{E}-01$ \\
\hline U-235 & $2.2 \mathrm{E}+02$ & $1.0 \mathrm{E}-02$ & $3.7 \mathrm{E}+03$ & $5.9 \mathrm{E}-03$ & $1.6 \mathrm{E}-02$ \\
\hline U-238 & $2.2 \mathrm{E}+02$ & $2.1 \mathrm{E}-01$ & $2.5 \mathrm{E}+03$ & $3.6 \mathrm{E}-02$ & $2.5 \mathrm{E}-01$ \\
\hline Total & & $4.8 \mathrm{E}-01$ & & $6.5 \mathrm{E}-02$ & $5.5 \mathrm{E}-01$ \\
\hline
\end{tabular}

(a) $\mathrm{BCG}=$ Biota concentration guide.

(b) Denotes radionuclide only identified in water sample, sediment value generated using program default distribution coefficient.

The National Council on Radiation Protection (NCRP 1991), in their review conducted of aquatic dose rates for DOE, proposed a "trigger' value of $0.25 \mathrm{rad}$ per day. This screening assessment had BDAC screening outputs in excess of the 0.25 (or 0.025 if applied to terrestrial animals) trigger level. NCRP recommended that additional evaluation be performed when this trigger value is exceeded in a dose assessment. Internal dose rates were estimated using the BDAC program. Comparisons of external dose rates associated with water and sediment exposure were also evaluated (Appendix E). These three pathways were summed to produce a more species-specific assessment of dose to aquatic and terrestrial biota.

The dose rates to specific organisms by location were estimated based on external dose rates for maximum measured radionuclides in sediment, water, and the biota samples. In some cases where multiple organs were sampled, the dose rates assume a uniform distribution throughout the organisms and the highest concentration was used to extrapolate dose to the entire organism (e.g., mouse bone - see Appendix E). Species-specific dose rates were well below (by 2 to 4 orders of magnitude) the proposed guidelines of $1 \mathrm{rad}$ per day for terrestrial plants and aquatic organisms, or the $0.1 \mathrm{rad}$ per day guideline for terrestrial or riparian animals. The maximum estimated dose rate was $0.0095 \mathrm{rad}$ per day for crayfish residing at Location 11. This may still be considered conservative as the dose rate may be biased high due to the measured concentration of uranium in hepatopancreas (see Appendix E).

Other biota samples were analyzed for radionuclide content, but potassium-40, a primordial radionuclide, was the only radionuclide detected in any sculpin or crayfish sample analyzed. No dose assessment was performed on these data; hence, these biota dose assessments are based on the contribution from anthropogenic radionuclides found in the 300 Area shoreline environment. Biota samples were also 
submitted for ICP-MS analysis of metals, which detected uranium-238 in clams, sculpin liver, and crayfish hepatopancreas (Appendix E). Estimated radiological doses from internal deposition of uranium isotopes (based on the relative abundance of uranium isotopes) to selected organs ranged from 0.09 to $36 \mathrm{mrad}$ per day. Whole-body dose rates to these organisms were not calculated; however, the tissues sampled are likely to accumulate higher concentrations of uranium than other tissues and if extrapolated to whole body doses, the resulting dose could be considered conservative.

\subsubsection{Summary}

Doses to biota inhabiting the shoreline along the 300 Area and Vernita Bridge locations passed the initial BDAC screening of radionuclide concentrations. Site and species-specific dose estimates were 1 to 4 orders of magnitude less than dose rates that could be inferred by the screening sum of fractions, indicating adequate conservatism in the screening methods. Estimated dose rates for terrestrial animals and aquatic organisms were well below the respective guidelines of 0.1 and $1 \mathrm{rad}$ per day. Maximum external doses from exposure to river water and sediments were estimated for Location 9. Table 6.2 shows combined calculated internal and external doses. Site-specific calculations were two to three orders of magnitude below results from the screening calculations, due to the conservatism built into the biota dose calculator.

Table 6.2. $\quad$ Estimated Internal and External Dose Rates (rad/day) by Location and Biota

\begin{tabular}{||l|c|c|c|c|c|c||}
\hline \multirow{2}{*}{ Location } & \multicolumn{7}{|c|}{ Organism $^{(\mathrm{a})}$} \\
\cline { 2 - 7 } & Mulberry & Sweet Clover & Mouse & Sculpin & Crayfish & Clam \\
\hline \hline Spring 7 & $2.42 \mathrm{E}-04$ & $6.78 \mathrm{E}-05$ & $9.34 \mathrm{E}-05$ & $1.92 \mathrm{E}-04$ & $2.76 \mathrm{E}-03$ & $5.26 \mathrm{E}-03$ \\
\hline Spring 9 & $\mathrm{NS}^{(\mathrm{b})}$ & $\mathrm{NS}$ & NS & NS & NS & NS \\
\hline Spring 11 & $6.01 \mathrm{E}-05$ & $5.08 \mathrm{E}-05$ & $6.61 \mathrm{E}-05$ & $6.44 \mathrm{E}-05$ & $9.46 \mathrm{E}-03$ & $2.46 \mathrm{E}-03$ \\
\hline Spring 14 & $1.22 \mathrm{E}-05$ & $1.30 \mathrm{E}-05$ & $9.52 \mathrm{E}-06$ & $1.02 \mathrm{E}-04$ & $9.12 \mathrm{E}-04$ & $3.22 \mathrm{E}-04$ \\
\hline Vernita & $2.61 \mathrm{E}-05$ & $2.99 \mathrm{E}-05$ & $2.10 \mathrm{E}-05$ & $9.94 \mathrm{E}-05$ & $8.82 \mathrm{E}-04$ & $5.72 \mathrm{E}-04$ \\
\hline
\end{tabular}

(a) Dose limit is $1.0 \mathrm{rad} / \mathrm{d}$ except for the mouse, which is $0.1 \mathrm{rad} / \mathrm{d}$.

(b) NS = No sample.

\subsection{Chemical Assessment Results}

Risk to aquatic and riparian organisms can be indirectly and qualitatively evaluated by comparing concentrations of contaminates in water to existing water quality standards (Appendix A, Table A.2). Risk could also be addressed by comparing sediment concentrations of contaminants with proposed sediment standards; however, there is no consensus on freshwater standards and those that have been suggested for marine sediment are under intense review. This situation exists because sediment composition can be extremely variable and differences in $\mathrm{pH}$, organic content, mineral content, particle size distribution, water quality and other physical and chemical parameters that can influence the fate and potential effects of contaminants to aquatic organisms. 
Trichloroethylene and cis-dichloroethylene were the only volatile organic compounds detected for riverbank spring water samples and they were only detected for Location 9. The concentration of trichloroethylene was $2 \mu \mathrm{g} / \mathrm{L}$, which was below the federal level of $2.7 \mu \mathrm{g} / \mathrm{L}$ to protect human health for the consumption of water and organisms (40 CFR 131.36). No comparable federal standard was available for cis-dichloroethylene. There does not appear to be a significant exposure pathway for volatile organics for the riverbank spring discharge locations evaluated by this study.

Similarly, risk from trace metals can subjectively be assessed by comparing concentrations of the contaminant in riverbank spring water and river water to state surface water quality standards. In no case, did any of the non-actinide metals exceed state surface water quality criteria. Uranium was present in riverbank spring water (Locations 7 and 9) at levels exceeding the standard of $30 \mu \mathrm{g} / \mathrm{L}(\sim 20 \mathrm{pCi} / \mathrm{L})$. Concentrations at a depth of 0.25 meter also exceeded the $30 \mu \mathrm{g} / \mathrm{L}$ limit for uranium. Consequently, some risk to aquatic organisms exists in these areas where water concentrations exceed water quality standards. Concentrations of uranium in sediment pore water based on the drive point sample also indicate a greater spatial area of contamination. Most freshwater benthic biota inhabit only the top centimeters of the river bottom. Groundwater that upwells into the river will undergo some undefined level of dilution before it enters the river. While there is uncertainty as to what the concentrations of uranium are where they enter the river, it can conservatively be assumed that there is also elevated risk to sediment dwelling organisms in these areas. Examples of exposed organisms include sculpin, clam, crayfish, snails, insect larvae, periphyton, and possibly some oligochaete worms. The shallowest drive points were set at roughly 0.6 to 0.75 meter below grade and likely were below the maximum depth that would support most aerobic freshwater life.

Another approach to evaluating risk is to determine if the tissue concentrations of a given contaminant can be associated with observable deleterious effects (e.g., tissue damage, loss of function). While there are some databases that relate tissue concentrations of metals to adverse biological effects, the data is sparse and is focused on a small number of species. For the most part, the aquatic species (sculpin, crayfish, asian clam) collected in this study are not covered in these databases. Tissue burdens can vary significantly among different species. For example, the mean concentration of zinc in carp kidney collected in 1997 near the 300 Area was $1,100 \mu \mathrm{g} / \mathrm{g}$ dry wt. (Dirkes and Hanf 1998). In comparison, the mean concentration in bass kidney collected in 1997 from the same area was $69 \mu \mathrm{g} / \mathrm{g}$ dry wt. Given the range of what appears to be normal variation in tissue concentrations, it is apparent that to be useful, tissue-based criteria need to be developed for each species under consideration.

Another approach is to use the weight of evidence approach, where empirically derived results are obtained at the site of concern and compared to an expected set of results. Both individual and population level endpoints of injury can be assessed. In this study, a pilot effort was conducted to examine individual-level health of crayfish and sculpin. Clearly, uranium, selenium, and chromium accumulated in clam soft tissue to levels in excess of those collected at the reference site. Similar relationships were apparent in riverbank spring water samples and river water samples collected at both locations. What is not known is whether these levels of exposure and accumulation in tissue have an adverse impact on clams or other 300 Area aquatic biota. Health assessments were not performed on Asian clams; however, the health tests performed on crayfish and sculpin did not suggest any abnormal frequency of lesions in target tissues that was indicative of chemical or radiological toxicity. The health data of 300 Area organisms is preliminary and additional sampling for health effects will be needed to better evaluate potential injury that may exist in the 300 Area environment. 


\subsection{Conclusions}

This study evaluated the radiological and chemical contaminants in the near-shore environment of the Columbia River at the 300 Area of DOE's Hanford Site and at a background location. The study was conducted at low river stage to facilitate the sampling riverbank spring water and other media and thus, represents a likely worst-case scenario for contaminants entering the Columbia River from the groundwater pathway. Near-shore river water, cross-river transect water, riverbank spring water, shallow groundwater, river sediment, aquatic biota, and riparian biota were all sampled. This study also measured near- and off-shore external radiation levels. The data represent current contaminant levels and were used to evaluate human and ecological impacts.

For riverbank spring water and near-shore river water, only gross alpha and uranium exceeded state ambient surface water quality criteria. The water samples that exceeded the water criteria were taken directly from the riverbank spring discharge or from near-shore water in the immediate vicinity of the spring (i.e., river depth of 0.25 meter, directly off-shore from the spring). However, the subsequent river water sample at river depth of 0.5 meter was less than $12 \%$ of the water quality criteria for uranium. All samples taken from the shallow groundwater drive points at Locations 7 and 9 exceeded the water quality criteria for uranium. Uranium isotopic abundances were similar for all locations and did not reveal isotopic enrichments in the 300 Area near shore.

Tritium and uranium concentration in river water were highest in the vicinity of the flowing riverbank springs. Generally, the highest concentrations were detected at the nearest-to-shore locations, with the samples taken at greater river depth having lower concentrations. Within a specific location, contaminant concentrations in the water column were usually higher for samples with higher specific conductivity.

At the 300 Area's southern border, a cross-river water sampling transect found that all water samples were below ambient surface water quality criteria and that slightly elevated (compared to both mid-river) concentrations of anions and total uranium were found for the Franklin County shore. The slightly elevated concentrations of anions and total uranium along the Franklin County shoreline has been observed in prior sampling efforts and likely resulted from extensive irrigation in the area (Poston et al. 2001; Poston et al. 2002).

Shallow groundwater (drive points) had higher specific conductivity than the associated riverbank spring and the specific conductivity values generally increased with the depth of placement below the riverbed. Tritium concentration in shallow groundwater generally increased with depth below the riverbed; however, no clear trend for uranium concentrations verse depth below the riverbed was observed.

Riverbank springs appear to be the primary source of radionuclides to the 300 Area environment during low river flow periods. During low river stage, radionuclide upwelling from the river bottom appears to be a less significant source of contaminants than direct riverbank spring discharges since radionuclide levels decreased rapidly for both increasing river depth and shoreline distance from the actively flowing springs. There was evidence for groundwater upwelling of contaminants into the river at 
Location 11, where no flowing riverbank spring was observed; however, river water samples from this location had lower concentrations of contaminants than locations with active riverbank springs.

For sediment samples, the concentrations of strontium-90, cesium-137, and uranium isotopes were elevated for the 300 Area near-shore, compared to the Vernita Bridge. For uranium isotopes, the order of concentrations (highest to lowest) was Location 9, Location 7, Location 11, and Location 14. Uranium results for sediment from Location 9 was about 4.4 times the value for Vernita Bridge sediment, while the results for Location 14 (farthest downstream) was only 1.6 times the Vernita Bridge value. The concentrations of metals in 300 Area near-shore sediment were similar or lower than for sediment collected at Vernita Bridge.

Biota in the near-shore riparian community in the 300 Area had elevated concentrations of tritium, technetium-99, and uranium compared to the Vernita Bridge site. Mulberry samples generally had higher concentrations of radionuclides than sweet clover, and this may be related to the deeper rooting of the mulberry. Uranium was measured in mice samples at the 300 Area; however, a comparison to background was not possible because no mice were captured at the background site. There were a few nearshore samples from the 300 Area with elevated metals (chromium in one sweet clover sample, selenium in one mouse sample [no mice were collected at Vernita Bridge]), and possibly some elevated zinc) compared to the Vernita Bridge background, but most results were comparable to background.

Biota in the near-shore aquatic community in the 300 Area had elevated concentrations of technetium-99 and uranium compared to the Vernita Bridge location. Concentration of arsenic, beryllium, chromium, selenium, and zinc also were elevated, compared to the Vernita background site, in some near-shore biota samples collected at the 300 Area. Individual clam samples were collected over a well-defined spatial range, and this allowed the aquatic habitat area in the 300 Area with elevated concentrations of chromium, selenium, and uranium to be estimated.

An inspection of individual-level health revealed that the majority of biotic tissues from near the shore at both the 300 Area and the Vernita Bridge background location did not have significant lesions. However, the total number of samples was limited, and this prevented detailed statistical comparisons.

External radiation measurements on the 300 Area shoreline had a maximum rate of $10.0 \mu \mathrm{R}$ per hour, compared to $10.2 \mu \mathrm{R}$ per hour at the background location near Vernita Bridge. No difference between the two location's maximum and average exposure rates was identified.

This report used a unit dose approach to allow estimate human doses from specific activities near the 300 Area near shore. The unit dose for external radiation was 0 mrem per hour because the external dose rates were lower at the 300 Area compared to background. The unit dose for the ingestion of 1 liter of river water from the area with the highest concentrations of uranium and tritium (Location 9) was $0.011 \mathrm{mrem} / \mathrm{L}$ with uranium-234 and -238 being the dominant dose contributors. Uranium-235 and tritium had small contributions to the unit dose for water, with all other radionuclide being negligible. The unit dose from ingestion of 1 gram of clam meat from the area with the maximum uranium concentrations was $0.00065 \mathrm{mrem} / \mathrm{g}$. The human doses from radionuclides calculated from likely current-use exposures, fishing and boating, are low and not expected to be harmful to people engaged in these activities. 
For chemicals, the human dose from activities at the 300 Area near shore is primarily from uranium. Uranium was above ambient water quality criteria for shallow groundwater samples, riverbank spring water, and Columbia River water in the immediate vicinity of the riverbank springs. However, the spatial extent of the elevated uranium concentration was limited due to dilution and dispersion. The human doses from chemicals from likely current-use exposures, fishing and boating, are low and not expected to be harmful for people engaged in these activities.

Estimated dose rates for terrestrial animals and aquatic organisms were well below the respective guidelines of 0.1 and $1 \mathrm{rad}$ per day. The maximum external doses from exposure to river water and sediment were estimated for the active riverbank spring at Location 9. Site-specific calculations were two to three orders of magnitude below results from the screening calculations, due to the conservatism built into the biota dose calculator.

Overall, this study was able to track the progression of 300 Area groundwater contaminants from shallow groundwater, to riverbank springs, and ultimately to near-shore river water, sediment, and biota. Discharges of riverbank spring water appear to be the major source of 300 Area groundwater contaminants entering the river during low river flow conditions. The contaminants detected in the 300 Area that were above background levels were similar to those found in previous studies. For shallow groundwater, riverbank spring water, and near-shore river water samples from the 300 Area, gross alpha and uranium were the only contaminant that exceeded Washington State ambient surface water quality criteria. The contaminants in the 300 Area near-shore water samples that were elevated compared to the background location were arsenic, barium, cesium-137, chromium, iodine-129, selenium, technetium-99, thallium, tritium, uranium, and zinc. Clam samples were shown to be effective for estimating the aquatic habitat area in the 300 Area with elevated concentrations of chromium, selenium, and uranium. Similar spatial profiles were observed for uranium concentrations in near-shore river water (at low river stage) and uranium in soft tissues of clams (i.e., concentrations decreased with increasing distance from the flowing riverbank springs). Radiological and chemical exposure assessment for both human and biota exposed to the 300 Area near-shore environment did not reveal any likely problems. 


\subsection{References}

40 CFR 131.36. U.S. Environmental Protection Agency. "Toxics Criteria for Those States not Complying with the Clean Water Act Section 303 (c) (2) (B). Code of Federal Regulations.

Bates, D., and J. Cubbage. 1995. Summary of Guidelines for Contaminated Freshwater Sediments. Environmental Investigations and Laboratory Services Program, Washington State Department of Ecology, Olympia, Washington.

Bisping, L. E. 2001. Hanford Site Environmental Surveillance Master Sampling Schedule. PNNL13418, Pacific Northwest National Laboratory, Richland, Washington.

Blanton, M. L., W. W. Gardiner, and R. L. Dirkes. 1995. Environmental Monitoring of Columbia River Sediment: Grain-Size Distribution and Contaminant Association. PNL-10535, Pacific Northwest Laboratory, Richland, Washington.

CERCLA - Comprehensive Environmental Response, Compensation, and Liability Act. 1980. Public Law 96-150, as amended, 94 Stat. 2767, 42 USC 9601 et seq.

Dirkes, R. L. 1990. 1988 Hanford Riverbank Springs Characterization Report. PNL-7500, Pacific Northwest Laboratory, Richland, Washington.

Dirkes, R. L. 1993. Columbia River Monitoring: Distribution of Tritium in Columbia River Water at the Richland Pumphouse. PNL-8531, Pacific Northwest Laboratory, Richland, Washington.

Dirkes, R. L. 1994. Summary of Radiological Monitoring of Columbia River Water Along the Hanford Reach, 1980 Through 1989. PNL-9223, Pacific Northwest Laboratory, Richland, Washington.

Dirkes, R. L. and R. W. Hanf. 1998. Hanford Site Environmental Report for Calendar Year 1997. PNNL-11795, Pacific Northwest National Laboratory, Richland, Washington.

Dirkes, R. L., G. W. Patton, and B. L. Tiller. 1993. Columbia River Monitoring: Summary of Chemical Monitoring Along Cross Sections at Vernita Bridge and Richland. PNL-8654, Pacific Northwest Laboratory, Richland, Washington.

DOE Order 5400.1. "General Environmental Protection Program."

DOE Order 5400.5. "Radiation Protection of the Public and the Environment."

DOE. 2002. A Graded Approach for Evaluating Radiation Doses to Aquatic and Terrestrial Biota. Final Technical Standard No. DOE-STD-1153-2002. Office of Environmental Policy and Guideline, Washington, D.C.

DOE/RL. 1993. Phase I and Phase II Feasibility Study Report for the 300-FF-1 Operable Unit. DOE/RL-92-46, Rev. 0, U.S. Department of Energy, Richland Operations Office, Richland, Washington. 
DOE/RL. 1995. Remedial Investigation/Feasibility Study Report for the 300-FF-5 Operable Unit.

DOE/RL-94-85, Rev. 0, U.S. Department of Energy, Richland Operations Office, Richland, Washington.

DOE/RL. 1997. Limited Field Investigation Report for the 300-FF-2 Operable Unit. DOE/RL-96-42, Rev. 0., U.S. Department of Energy, Richland Operations Office, Richland, Washington.

DOE/RL. 2000a. Focused Feasibility Study for the 300-FF-2 Operable Unit. DOE/RL-99-40, Rev. 0, U.S. Department of Energy, Richland Operations Office, Richland, Washington.

DOE/RL. 2000b. Environmental Monitoring Plan, United States Department of Energy Richland Operations Office. DOE/RL-91-50, Rev. 3, U.S. Department of Energy, Richland Operations Office, Richland, Washington.

DOE/RL. 2002. Operations and Maintenance Plan for the 300-FF-5 Operable Unit. DOE/RL-95-73, Rev. 1, U.S. Department of Energy, Richland Operations Office, Richland, Washington.

EC. 1994. Interim Sediment Quality Assessment (Draft). Environment Canada, Soil and Sediment Quality Section, Guidelines Division, Ecosystem Conservation Directorate, Evaluation and Interpretation Branch, Ottawa, Ontario, Canada.

EPA. 1996. Record of Decision for the 300-FF-1 and 300-FF-5 Operable Units. Issued by the U.S. Environmental Protection Agency, Washington State Department of Ecology, and U.S. Department of Energy, Richland Operations Office, Richland, Washington.

EPA. 2001. Declaration of the Record of Decision for the 300-FF-2 Operable Unit. U.S. Environmental Protection Agency, Washington, D.C.

EPA Method 8260. 1986. Volatile Organic Compounds by Gas Chromatography/Mass Spectrometry (GC/MS). Test Methods for Evaluating Solid Waste, Physical/Chemical Methods. SW-846. Office of Solid Waste and Emergency Response, U.S. Environmental Protection Agency, Washington, D.C.

Friant, S. L. and L. C. Hulstrom. 1993. Sampling and Analysis of the 300-FF-5 Operable Unit Springs and Near Shore Sediments and River Water. WHC-SD-EN-TI-125, Westinghouse Hanford Company, Richland, Washington.

Healey, M. C. 1991. "Life History of Chinook Salmon (Oncorhynchus tshawytscha)". In Pacific Salmon Life Histories. C. Groot and L. Margolis (eds.), UBC Press, Vancouver, Canada.

ICRP. 1996. Age-Dependent Doses to Members of the Public from Intake of Radionuclides: Part 5, Compilation of Ingestion and Inhalation Dose Coefficients. International Commission on Radiation Protection Publication 72, Annuals of the ICRP 26(1), Pergamon Press, Oxford, England.

Lindberg, J. W. and C. J. Chou. 2001. 300 Area Process Trenches Groundwater Monitoring Plan. PNNL-13645, Pacific Northwest National Laboratory, Richland, Washington. 
Maher, F. P. and P. A. Larkin. 1954. "Life History of the Steelhead Trout of the Chilliwack RiverBritish Columbia." Trans. Am. Fish. Soc. 84:27-38.

NCRP. 1991. Effects of Ionizing Radiation on Aquatic Organisms. NCRP Report No. 109, National Council on Radiation Protection, Bethesda, Maryland.

Reiman, R. T. and T. S. Dahlstrom. 1990. An Aerial Radiological Survey of the Hanford Site and Surrounding Area. EGG-10617-1062, EG\&G Energy Measurements, Las Vegas, Nevada.

Patton, G. W. and E. A. Crecelius. 2001. Simultaneously Extracted Metals / Acid Volatile Sulfide and Total Metals in Surface Sediment from the Hanford Reach of the Columbia River and the Lower Snake River. PNNL-13417, Pacific Northwest National Laboratory, Richland, Washington.

Persaud, D., R. Jaagumagi, and A. Hayton. 1992. Guidelines for Protection and Management of Aquatic Sediment Quality in Ontario. Water Resources Branch, Ontario Ministry of the Environment, Toronto, Canada.

PNL-MA-580. Surface Environmental Surveillance Procedures Manual. Pacific Northwest National Laboratory, Richland, Washington.

PNL-SC-01, Rev. 1. Inductively Coupled Plasma Mass Spectrometric (ICP-MS) Analysis. Pacific Northwest National Laboratory, Richland, Washington.

Poston, T. M. 1994. Trends in Radionuclide Concentrations in Hanford Reach Fish, 1982 through 1992. PNL-9960, Pacific Northwest Laboratory, Richland, Washington.

Poston, T. M., R. W. Hanf, R. L. Dirkes, and L. F. Morasch (eds.). 2001. Hanford Site Environmental Report for Calendar Year 2000. PNNL-13486, Pacific Northwest National Laboratory, Richland, Washington.

Poston, T. M., R. W. Hanf, R. L. Dirkes, and L. F. Morasch (eds.). 2002. Hanford Site Environmental Report for Calendar Year 2001. PNNL-13910, Pacific Northwest National Laboratory, Richland, Washington.

RCRA - Resource Conservation and Recovery Act. 1976. Public Law 94-580, as amended, 90 Stat. 2795, 42 USC 6901 et seq.

Reiman, R. T. and T. S. Dahlstrom. 1990. An Aerial Radiological Survey of the Hanford Site and Surrounding Area, Richland, Washington. EGG-10617-1062, EG\&G Energy Measurements, Las Vegas, Nevada.

Rosenberg and Resh (eds.). 1993. Freshwater Biomonitoring and Benthic Macroinvertebrate. Chapman and Hall, Inc., New York. 
Van Verst, S. P., C. L. Albin, G. W. Patton, M. L. Blanton, T. M. Poston, A. T. Cooper, and E. J. Antonio. 1998. Survey of Radiological Contaminants in the Near-Shore Environment at the Hanford Site 100-N Reactor Area. PNNL-11933, Pacific Northwest National Laboratory, Richland, Washington.

WAC 173-201A. "Water Quality Standards for Surface Waters of the State of Washington." Washington Administrative Code, Olympia, Washington.

WAC 173-204. “Sediment Management Standard.” Washington Administrative Code, Olympia, Washington.

WAC 246-290. “Group A Public Water Systems.” Washington Administrative Code, Olympia, Washington.

Washington State W.R. Giedt Public Health Laboratories. 2001 Radiation Chemistry Procedure Manual. Washington State Department of Health, Shoreline, Washington.

Washington Department of Wildlife (WDW). 1983. Summer Steelheading in Washington. Olympia, Washington (Available at http://www.wa.gov/wdfw/archives/angling.htm). 


\section{Appendix A}

\section{General Appendix}


Table A.1. Geophysical Positioning System (GPS) Coordinates for Sampling Locations

\begin{tabular}{|c|c|c|c|c|c|}
\hline \multirow[b]{2}{*}{ Location } & \multirow[b]{2}{*}{ Description } & NAD $1983^{(a)}$ & NAD $1983^{(a)}$ & WGS84 & WGS84 \\
\hline & & Easting (m) & Northing $(\mathrm{m})$ & Longitude $^{\circ}$ & Latitude $^{\circ}$ \\
\hline Vernita & Vernita Bridge (background location) & 557558.7 & 144902.5 & -119.74824 & 46.63453 \\
\hline \multicolumn{6}{|l|}{300 Area } \\
\hline $7(0.0)$ & Location 7 & 594392.9 & 116697.3 & -119.27295 & 46.37664 \\
\hline $7(0.25)$ & Location 7 ( $0.25 \mathrm{~m}$ depth river) & 594399.3 & 116695.8 & -119.27287 & 46.37663 \\
\hline $7(0.5)$ & Location 7 (0.5 m depth river) & 594402.1 & 116695.2 & -119.27283 & 46.37662 \\
\hline $7(1.0)$ & Location 7 (1 m depth river) & 594405.0 & 116696.5 & -119.27280 & 46.37663 \\
\hline $7(1.5)$ & Location 7 (1.5 $\mathrm{m}$ depth river) & 594407.8 & 116693.7 & -119.27276 & 46.37661 \\
\hline 7DR $(0.25)$ & Downriver Location 7 ( $0.25 \mathrm{~m}$ depth river) & 594418.1 & 116567.5 & -119.27265 & 46.37547 \\
\hline 7DR $(0.5)$ & Downriver Location 7 ( $0.5 \mathrm{~m}$ depth river) & 594420.2 & 116567.6 & -119.27262 & 46.37547 \\
\hline 7DR (1.0) & Downriver Location 7 (1 m depth river) & 594425.6 & 116567.9 & -119.27255 & 46.37547 \\
\hline 7DR (1.5) & Downriver Location 7 (1.5 m depth river) & 594428.0 & 116566.5 & -119.27252 & 46.37546 \\
\hline $7 / 9(0.25)$ & Location $7 / 9$ (0.25 $\mathrm{m}$ depth river $)$ & 594450.3 & 116362.2 & -119.27227 & 46.37362 \\
\hline $9(0.0)$ & Location 9 & 594494.7 & 116202.6 & -119.27173 & 46.37218 \\
\hline $9(0.25)$ & Location 9 ( $0.25 \mathrm{~m}$ depth river $)$ & 594495.7 & 116205.7 & -119.27172 & 46.37220 \\
\hline $9(0.5)$ & Location 9 ( $0.5 \mathrm{~m}$ depth river $)$ & 594499.4 & 116203.2 & -119.27167 & 46.37218 \\
\hline $9(1.0)$ & Location 9 (1 m depth river) & 594502.0 & 116209.2 & -119.27163 & 46.37223 \\
\hline $9(1.5)$ & Location 9 (1.5 m depth river) & 594508.9 & 116209.2 & -119.27154 & 46.37223 \\
\hline 9DR (0.25) & Downriver Location 9 ( $0.25 \mathrm{~m}$ depth river) & 594510.2 & 116145.8 & -119.27154 & 46.37166 \\
\hline 9DR (0.5) & Downriver Location 9 ( $0.5 \mathrm{~m}$ depth river) & 594511.6 & 116147.9 & -119.27152 & 46.37168 \\
\hline 9DR (1.0) & Downriver Location 9 ( $1 \mathrm{~m}$ depth river) & 594518.8 & 116146.1 & -119.27143 & 46.37166 \\
\hline 9DR (1.5) & Downriver Location 9 ( $1.5 \mathrm{~m}$ depth river) & 594523.1 & 116145.8 & -119.27137 & 46.37166 \\
\hline $9 / 11(0.25)$ & Location $9 / 11$ (0.25 m depth river) & 594571.7 & 115910.0 & -119.27079 & 46.36953 \\
\hline $11(0.25)$ & Location 11 (0.25 m depth river) & 594644.2 & 115645.5 & -119.26990 & 46.36714 \\
\hline $11(0.5)$ & Location 11 (0.5 m depth river) & 594646.1 & 115646.0 & -119.26987 & 46.36715 \\
\hline $11(1.0)$ & Location 11 (1 m depth river) & 594647.4 & 115645.6 & -119.26986 & 46.36714 \\
\hline $11(1.5)$ & Location 11 (1.5 m depth river) & 594650.1 & 115647.6 & -119.26982 & 46.36716 \\
\hline $14(0.25)$ & Location 14 (0.25 m depth river) & 594889.7 & 114361.6 & -119.26697 & 46.35556 \\
\hline $14(0.5)$ & Location 14 (0.5 m depth river) & 594892.5 & 114361.9 & -119.26693 & 46.35556 \\
\hline $14(1.0)$ & Location 14 (1 m depth river) & 594893.3 & 114362.4 & -119.26692 & 46.35557 \\
\hline $14(1.5)$ & Location 14 (1.5 m depth river) & 594896.6 & 114364.3 & -119.26688 & 46.35558 \\
\hline 300 Area & \multicolumn{5}{|l|}{ Shallow Groundwater Drivepoint } \\
\hline $7-1$ & Location 7, 7-1 (Drivepoint $2.5 \mathrm{ft}$ depth) & 594398.4 & 116699.5 & -119.27290 & 46.37666 \\
\hline $7-1$ & Location 7, 7-1 (Drivepoint $4 \mathrm{ft}$ depth) & 594398.4 & 116699.5 & -119.27290 & 46.37666 \\
\hline $7-1$ & Location 7, 7-1 (Drivepoint $6 \mathrm{ft}$ depth) & 594398.4 & 116699.5 & -119.27290 & 46.37666 \\
\hline
\end{tabular}


Table A.1. (contd)

\begin{tabular}{||l|l|c|c|c|c||}
\hline \multirow{2}{*}{ Location } & \multicolumn{1}{|c|}{ Description } & NAD 1983 & NAD 1983 & WGS84 & WGS84 \\
\cline { 3 - 6 } & & Easting (m) & Northing (m) & Longitude $^{\circ}$ & Latitude $^{\circ}$ \\
\hline \hline $7-2$ & Location 7, 7-2 (Drivepoint 2 ft depth) & 594403.2 & 116701.7 & -119.27280 & 46.37668 \\
\hline $7-2$ & Location 7, 7-2 (Drivepoint 4.2 ft depth) & 594403.2 & 116701.7 & -119.27280 & 46.37668 \\
\hline $9-1$ & Location 9, 9-1 (Drivepoint 2 ft depth) & 594489.8 & 116209.4 & -119.27180 & 46.37224 \\
\hline $9-1$ & Location 9, 9-1 (Drivepoint 4 ft depth) & 594489.8 & 116209.4 & -119.27180 & 46.37224 \\
\hline $9-2$ & Location 9, 9-2 (Drivepoint 2 ft depth) & 594496.9 & 116210.3 & -119.27170 & 46.37225 \\
\hline $9-2$ & Location 9, 9-2 (Drivepoint 4.5 ft depth) & 594496.9 & 116210.3 & -119.27170 & 46.37225 \\
\hline $9-3$ & Location 9, 9-3 (Drivepoint 5.5 ft depth) & 594503.1 & 116210.8 & -119.27160 & 46.37225 \\
\hline
\end{tabular}

(a) NAD 1983 (Conus), US State Plane 1983, WA South 4602, m, HAE.

GPS coordinates were not recorded for the 11 DR location. 
Table A.2. Selected Surface Freshwater Quality Criteria for Toxic Pollutants

\begin{tabular}{|c|c|c|c|}
\hline Compound & $\begin{array}{l}\text { Level that Yields Acute } \\
\text { Toxicity, } \mu \mathrm{g} / \mathrm{L}^{\text {(a) }}\end{array}$ & $\begin{array}{l}\text { Level that Yields Chronic } \\
\text { Toxicity, } \mu \mathrm{g} / \mathrm{L}^{(\mathrm{a})}\end{array}$ & $\begin{array}{c}\text { Level to Protect Human Health for the } \\
\text { Consumption of Water and Organisms, } \mu \mathrm{g} / \mathrm{L}^{(\mathrm{b})}\end{array}$ \\
\hline \multicolumn{4}{|l|}{ Dissolved Metals } \\
\hline Antimony & -- & -- & 14 \\
\hline Arsenic & 360.0 & 190.0 & 0.018 \\
\hline Cadmium & $1.6^{(\mathrm{c})}$ & $0.59^{(\mathrm{d})}$ & -- \\
\hline Chromium(VI) & 16 & 10 & -- \\
\hline Copper & $8.4^{(\mathrm{e})}$ & $6.0^{(\mathrm{f})}$ & -- \\
\hline Lead & $28^{(\mathrm{g})}$ & $1.1^{(\mathrm{h})}$ & -- \\
\hline Nickel & $750^{(i)}$ & $83^{(\mathrm{j})}$ & 610 \\
\hline Silver & $0.94^{(\mathrm{k})}$ & -- & -- \\
\hline Thallium & -- & -- & 1.7 \\
\hline Zinc & $60^{(1)}$ & $55^{(\mathrm{m})}$ & -- \\
\hline \multicolumn{4}{|c|}{ Total Recoverable Metals } \\
\hline Chromium(III) ${ }^{(\mathrm{n})}$ & $300^{(0)}$ & $96^{(\mathrm{p})}$ & -- \\
\hline Mercury & 2.1 & 0.012 & 0.14 \\
\hline Selenium & 20 & 5.0 & -- \\
\hline \multicolumn{4}{|l|}{ Anions } \\
\hline Cyanide $^{(\mathrm{q})}$ & 22.0 & 5.2 & 700 \\
\hline Chloride $^{(\mathrm{r})}$ & 860,000 & 230,000 & -- \\
\hline \multicolumn{4}{|l|}{ Organic Compounds } \\
\hline Benzene & -- & -- & 1.2 \\
\hline Carbon tetrachloride & -- & -- & 0.25 \\
\hline Chloroform & -- & -- & 5.7 \\
\hline 1,2-Dichloroethane & -- & -- & 0.38 \\
\hline Methylene chloride & -- & -- & 4.7 \\
\hline Toluene & -- & -- & 6,800 \\
\hline Tetrachloroethene & -- & -- & 0.8 \\
\hline 1,1,2-Trichloroethane & -- & -- & 0.60 \\
\hline Trichloroethene & -- & -- & 2.7 \\
\hline \multirow{2}{*}{$\begin{array}{l}\text { Vinyl chloride } \\
1,4 \text {-Dichlorobenzene } \\
\end{array}$} & -- & -- & 2 \\
\hline & -- & -- & 400 \\
\hline 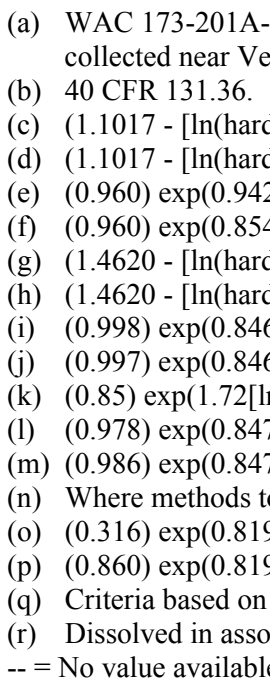 & $\begin{array}{l}\text { or hardness dependent crit } \\
\text { idge by the U.S. Geologic } \\
0.04184) \exp (1.128[\ln (\text { har } \\
0.04184) \exp (0.7852[\ln (\text { ha } \\
\text { ardness })]-1.464) \text {. } \\
\text { ardness)]-1.465). } \\
0.1457) \exp (1.273[\ln (\text { hard } \\
0.1457) \exp (1.273[\ln (\text { hard } \\
\text { ardness })]+3.3612) \text {. } \\
\text { ardness })]+1.1645) \text {. } \\
\text { ess)]-6.52). } \\
\text { ardness)]+0.8604). } \\
\text { ardness) }]+0.7614) \text {. } \\
\text { are trivalent chromium are } \\
\text { ardness) }]+3.688) \text {. } \\
\text { ardness)]+1.561). } \\
\text { nd dissociable method. } \\
\text { with sodium. }\end{array}$ & $\begin{array}{l}\text { the minimum value of } 47 \\
\text { Survey is used. } \\
\text { ss)]-3.828). Hardness expr } \\
\text { ess)]-3.490). } \\
\text { s)]-1.460). } \\
\text { s)]-4.705). }\end{array}$ & $\begin{array}{l}\mathrm{CaCO}_{3} / \mathrm{L} \text { for } 1992-2000 \text { water samples } \\
\text { as } \mathrm{mg} \mathrm{CaCO}_{3} / \mathrm{L} \text {. } \\
\text { e represented by total recoverable chromium. }\end{array}$ \\
\hline
\end{tabular}


Table A.3. Comparative Sediment Quality Criteria

\begin{tabular}{|c|c|c|c|c|c|c|c|}
\hline \multirow{2}{*}{ Comparative Sediment Criteria } & \multicolumn{7}{|c|}{ Concentrations $(\mu \mathrm{g} / \mathrm{g}$ dry $\mathrm{wt})$} \\
\hline & $\mathrm{Hg}$ & $\mathbf{B e}$ & $\mathbf{C r}$ & $\mathbf{N i}$ & $\mathbf{C u}$ & $\mathbf{Z n}$ & As \\
\hline Ontario Lowest Effect Level $^{(\mathrm{a})}$ & 0.2 & NS & 26 & 16 & 16 & 120 & 6 \\
\hline Environ. Canada Threshold Effect Level ${ }^{(b)}$ & 0.174 & NS & 37.3 & 18 & 35.7 & 123.1 & 5.9 \\
\hline Ontario Sever Effect Level $^{(a)}$ & 2 & NS & 110 & 75 & 110 & 820 & 33 \\
\hline \multirow[t]{2}{*}{ Environ. Canada Probable Effect Level ${ }^{(\mathrm{b})}$} & 0.486 & NS & 90 & 35.9 & 196.6 & 314.8 & 17 \\
\hline & Se & Ag & Cd & $\mathbf{S b}$ & $\mathbf{T l}$ & $\mathbf{P b}$ & \\
\hline Ontario Lowest Effect Level $^{(\mathrm{a})}$ & NS & 0.5 & 0.596 & NS & NS & 31 & \\
\hline Environ. Canada Threshold Effect Level ${ }^{(b)}$ & NS & NS & 0.6 & NS & NS & 35 & \\
\hline Ontario Sever Effect Level ${ }^{(a)}$ & NS & NS & 10 & NS & NS & 250 & \\
\hline Environ. Canada Probable Effect Level ${ }^{(b)}$ & NS & NS & 3.53 & NS & NS & 91.3 & \\
\hline \multicolumn{8}{|l|}{$\begin{array}{l}\text { NS = No standard. } \\
\text { (a) Persaud et al. } 1992 . \\
\text { (b) EC } 1994 .\end{array}$} \\
\hline
\end{tabular}

\section{Appendix A References}

40 CFR 131.36. “Toxic Criteria for Those States not Complying with Clean Water Act.” Code of Federal Regulations.

EC. 1994. Interim Sediment Quality Assessment (Draft). Environment Canada, Soil and Sediment Quality Section, Guidelines Division, Ecosystem Conservation Directorate, Evaluation and Interpretation Branch, Ottawa, Ontario, Canada.

Persaud, D., R. Jaagumagi, and A. Hayton. 1992. Guidelines for Protection and Management of Aquatic Sediment Quality in Ontario. Water Resources Branch, Ontario Ministry of the Environment, Toronto, Canada.

WAC 173-201A-040. Toxic Substances. Washington Administrative Code, Olympia, Washington. 


\section{Appendix B}

\section{Results for Radiological Samples}


Table B.1. Radionuclides in Near-Shore River Water from the 300 Area and Vernita Bridge

\begin{tabular}{|c|c|c|c|c|c|c|c|c|c|c|c|c|c|c|c|c|c|}
\hline \multirow{3}{*}{$\begin{array}{l}\text { Sample Location } \\
\text { (depth, m) }\end{array}$} & \multirow{3}{*}{$\begin{array}{c}\text { Collection } \\
\text { Date }\end{array}$} & \multicolumn{4}{|c|}{$\begin{array}{c}\text { Gross Alpha } \\
\text { (pCi/L) }\end{array}$} & \multicolumn{4}{|c|}{$\begin{array}{c}\text { Gross Beta } \\
\text { (pCi/L) }\end{array}$} & \multicolumn{4}{|c|}{$\begin{array}{c}\text { Ruthenium-106 } \\
\text { (pCi/L) }\end{array}$} & \multicolumn{4}{|c|}{$\begin{array}{c}\text { Cesium-137 } \\
\text { (pCi/L0 }\end{array}$} \\
\hline & & \multicolumn{2}{|c|}{ SESP } & \multicolumn{2}{|c|}{ WDOH } & \multicolumn{2}{|c|}{ SESP } & \multicolumn{2}{|c|}{ WDOH } & \multicolumn{2}{|c|}{ SESP } & \multicolumn{2}{|c|}{ WDOH } & \multicolumn{2}{|c|}{ SESP } & \multicolumn{2}{|c|}{ WDOH } \\
\hline & & Result & Error & Result & Error & Result & Error & Result & Error & Result & Error & Result & Error & $\begin{array}{ll}\text { Result } \\
\end{array}$ & Error & Result & Error \\
\hline $\begin{array}{l}\text { River } 7(0.25) \\
\end{array}$ & \begin{tabular}{|l|}
$27-A u g-01$ \\
\end{tabular} & & & 99 & 3 & & & 9 & 2 & 2.16 & 22 & & & 0.704 & 2.2 & & \\
\hline River $7(0.5)$ & 27-Aug-01 & & & & & & & & & -22.5 & 20 & & & 0.921 & 2.3 & & \\
\hline River 7 (1.0) & 27-Aug-01 & & & & & & & & & -5.77 & 22 & & & -0.358 & 2 & & \\
\hline River 7 (1.5) & \begin{tabular}{|l|}
$27-A u g-01$ \\
\end{tabular} & & & & & & & & & 3.29 & 18 & & & 1.44 & 1.9 & & \\
\hline DR River $7(0.25)$ & 27-Aug-01 & & & & & & & & & -13.4 & 22 & & & 1.59 & 2.1 & & \\
\hline DR River $7(0.5)$ & 27-Aug-01 & & & & & & & & & 5.62 & 21 & & & 2.86 & 2.4 & & \\
\hline DR River 7 (1.0) & \begin{tabular}{|l|}
$27-A u g-01$ \\
\end{tabular} & & & & & & & & & -10.4 & 20 & & & 1.88 & 2 & & \\
\hline DR River 7 (1.5) & 27-Aug-01 & & & & & & & & & -7.67 & 20 & & & 1.04 & 2.3 & & \\
\hline River 7 to 9 & 27-Aug-01 & & & 0.7 & 1.4 & & & 1 & 2 & 4.9 & 19 & & & -0.243 & 2 & & \\
\hline River 9 $(0.25)$ & 27-Aug-01 & & & 70 & 11 & & & 25 & 3 & -9.75 & 18 & & & -0.971 & 1.8 & & \\
\hline River $9(0.5)$ & 27-Aug-01 & & & & & & & & & -19.6 & 22 & & & 0.936 & 2.3 & & \\
\hline River 9 (1.0) & 27-Aug-01 & & & & & & & & & -7.21 & 20 & & & 0.132 & 2.1 & & \\
\hline River 9 (1.5) & \begin{tabular}{|l|}
$27-A u g-01$ \\
\end{tabular} & & & & & & & & & -2.99 & 19 & & & -1.13 & 1.7 & & \\
\hline DR River $9(0.25)$ & 27-Aug-01 & & & & & & & & & 7.53 & 20 & & & -0.244 & 2 & & \\
\hline DR River $9(0.5)$ & 27-Aug-01 & & & & & & & & & 6 & 19 & & & 2.23 & 2 & & \\
\hline DR River $9(1.0)$ & 27-Aug-01 & & & & & & & & & 11.3 & 19 & & & 0.575 & 2.5 & & \\
\hline DR River 9 (1.5) & 27-Aug-01 & & & & & & & & & -4.79 & 18 & & & -2.19 & 2.3 & & \\
\hline River 9 to 11 & \begin{tabular}{|l|} 
27-Aug-01 \\
\end{tabular} & & & 0.6 & 1.4 & & & 0.8 & 1.6 & 6.54 & 22 & & & 0.482 & 2 & & \\
\hline River $11(0.25)$ & \begin{tabular}{|l|} 
27-Aug-01 \\
\end{tabular} & & & 9 & 3 & & & 4 & 2 & 3.47 & 18 & & & -0.337 & 2.1 & & \\
\hline River $11(0.5)$ & 27-Aug-01 & & & & & & & & & -9.69 & 18 & & & 0.0345 & 2.1 & & \\
\hline River $11(1.0)$ & 27-Aug-01 & & & & & & & & & -13.2 & 22 & & & 0.0126 & 2.5 & & \\
\hline River $11(1.5)$ & 27-Aug-01 & & & & & & & & & 1.11 & 17 & & & -2.89 & 2.1 & & \\
\hline DR River $11(0.25)$ & \begin{tabular}{|l|}
$27-A u g-01$ \\
\end{tabular} & & & & & & & & & -6.15 & 22 & & & 1.6 & 2.3 & & \\
\hline DR River $11(0.5)$ & 27-Aug-01 & & & & & & & & & 4.17 & 21 & & & -0.215 & 1.7 & & \\
\hline DR River $11(1.0)$ & 27-Aug-01 & & & & & & & & & 4.78 & 18 & & & -1.85 & 2 & & \\
\hline DR River 11 (1.5) & 27-Aug-01 & & & & & & & & & -8.21 & 21 & & & 1.21 & 2.4 & & \\
\hline River $14(0.25)$ & 27-Aug-01 & & & & & & & & & -2.13 & 22 & & & 0.301 & 2.4 & & \\
\hline River $14(0.5)$ & 27-Aug-01 & & & & & & & & & -12.5 & 21 & & & -0.301 & 2.1 & & \\
\hline River $14(1.0)$ & 27-Aug-01 & & & & & & & & & -8.3 & 16 & & & 2.19 & 2.2 & & \\
\hline River $14(1.5)$ & 27-Aug-01 & & & & & & & & & -7.36 & 22 & & & 0.934 & 2.1 & & \\
\hline Vernita $(0.25)$ & \begin{tabular}{|l|} 
27-Aug-01 \\
\end{tabular} & 1.04 & 0.93 & 0.5 & 1.3 & 1.54 & 1.6 & 0.3 & 1.6 & -12.5 & 17 & & & 0.819 & 2.1 & & \\
\hline Vernita $(0.5)$ & 27-Aug-01 & & & & & & & & & 1.43 & 21 & & & 0.629 & 2 & & \\
\hline Vernita (1.0) & 27-Aug-01 & & & & & & & & & -16.8 & 23 & & & 2.7 & 2.3 & & \\
\hline Vernita (1.5) & 27-Aug-01 & & & & & & & & & 10.7 & 17 & & & -2.07 & 1.8 & & \\
\hline
\end{tabular}


Table B.1. (contd)

\begin{tabular}{|c|c|c|c|c|c|c|c|c|c|c|c|c|c|c|c|c|c|c|c|c|c|}
\hline \multirow{3}{*}{$\begin{array}{l}\text { Sample Location } \\
\text { (depth, m) }\end{array}$} & \multirow{3}{*}{$\begin{array}{l}\text { Collection } \\
\text { Date }\end{array}$} & \multicolumn{4}{|c|}{$\begin{array}{l}\text { Uranium-234 } \\
(p C i / L)\end{array}$} & \multicolumn{4}{|c|}{$\begin{array}{l}\text { Uranium-235 } \\
(\mathrm{pCi} / \mathrm{L})\end{array}$} & \multicolumn{4}{|c|}{$\begin{array}{l}\text { Uranium-238 } \\
(\mathbf{p C i} / \mathrm{L})\end{array}$} & \multicolumn{4}{|c|}{$\begin{array}{c}\text { Total Uranium } \\
\text { (in radiological units of } \\
\text { pCi } / \mathrm{L} \text { ) }\end{array}$} & \multicolumn{4}{|c|}{$\begin{array}{c}\text { Total Uranium } \\
\text { (in chemical units of } \mu \mathrm{g} / \mathrm{L} \text { ) }\end{array}$} \\
\hline & & \multicolumn{2}{|c|}{ SESP } & \multicolumn{2}{|c|}{ WDOH } & \multicolumn{2}{|c|}{ SESP } & \multicolumn{2}{|c|}{ WDOH } & \multirow{2}{*}{\begin{tabular}{|l|} 
SESP \\
Result
\end{tabular}} & \multirow{2}{*}{ Error } & \multirow{2}{*}{\begin{tabular}{|l|} 
WDOH \\
Result \\
\end{tabular}} & \multirow[b]{2}{*}{ Error } & \multicolumn{2}{|c|}{ SESP $^{(a)}$} & \multicolumn{2}{|c|}{ WDOH } & \multirow{2}{*}{\begin{tabular}{l|} 
SESP $^{(\mathrm{a})}$ \\
Result
\end{tabular}} & \multirow[b]{2}{*}{ Error } & \multirow{2}{*}{\begin{tabular}{|l|} 
WDOH \\
Result \\
\end{tabular}} & \\
\hline & & Result & Error & Result & Error & Result & Error & Result & Error & & & & & Result & Error & Result & Error & & & & Error \\
\hline River $7(0.25)$ & 27-Aug-01 & 5.14 & 0.94 & & & 0.184 & 0.047 & & & 4.85 & 0.89 & & & 10.17 & 1.30 & & & 14.56 & 2.66 & & \\
\hline River $7(0.5)$ & 27-Aug-01 & 1.77 & 0.34 & & & 0.101 & 0.031 & & & 1.56 & 0.30 & & & 3.43 & 0.45 & & & 4.70 & 0.90 & & \\
\hline River 7 (1.0) & 27-Aug-01 & 0.56 & 0.12 & & & 0.008 & 0.009 & & & 0.44 & 0.09 & & & 1.01 & 0.15 & & & 1.32 & 0.28 & & \\
\hline River 7 (1.5) & 27-Aug-01 & 0.42 & 0.09 & & & 0.009 & 0.009 & & & 0.38 & 0.08 & & & 0.80 & 0.12 & & & 1.13 & 0.25 & & \\
\hline DR River $7(0.25)$ & 27 -Aug-01 & 1.43 & 0.27 & & & 0.062 & 0.022 & & & 1.27 & 0.25 & & & 2.76 & 0.37 & & & 3.82 & 0.75 & & \\
\hline DR River $7(0.5)$ & 27-Aug-01 & 0.61 & 0.12 & & & 0.014 & 0.011 & & & 0.48 & 0.10 & & & 1.10 & 0.16 & & & 1.44 & 0.30 & & \\
\hline DR River $7(1.0)$ & 27-Aug-01 & 0.42 & 0.09 & & & 0.013 & 0.010 & & & 0.35 & 0.08 & & & 0.79 & 0.12 & & & 1.06 & 0.23 & & \\
\hline DR River 7 (1.5) & 27-Aug-01 & 0.27 & 0.06 & & & 0.007 & 0.009 & & & \begin{tabular}{l|l|}
0.26 \\
\end{tabular} & 0.06 & & & 0.53 & 0.09 & & & 0.76 & 0.19 & & \\
\hline River 7 to 9 & 27-Aug-01 & 0.48 & 0.10 & & & 0.011 & 0.010 & & & \begin{tabular}{l|l}
0.37 \\
\end{tabular} & 0.08 & & & 0.86 & 0.13 & & & 1.12 & 0.25 & & \\
\hline River 9 $(0.25)$ & 27-Aug-01 & 30.50 & 5.50 & 29.1 & 1.7 & 1.140 & 0.220 & 1.56 & 0.26 & 27.80 & $\begin{array}{l}5.00 \\
\end{array}$ & 28.4 & 1.7 & 59.44 & 7.44 & 59.06 & 2.42 & 83.47 & 14.92 & 85.46 & 5.07 \\
\hline River 9 (0.5) & 27-Aug-01 & 1.31 & 0.26 & 1.4 & 0.28 & 0.061 & 0.026 & 0.031 & 0.087 & \begin{tabular}{l|l}
1.17 \\
\end{tabular} & 0.24 & 1.29 & \begin{tabular}{|l|}
0.27 \\
\end{tabular} & 2.54 & 0.35 & 2.72 & 0.40 & 3.52 & 0.72 & 3.86 & 0.81 \\
\hline River 9 (1.0) & 27-Aug-01 & 0.36 & 0.08 & 0.4 & 0.14 & 0.014 & 0.012 & 0.028 & 0.056 & 0.35 & 0.08 & 0.27 & \begin{tabular}{|l|l|}
0.12 \\
\end{tabular} & 0.72 & 0.12 & 0.70 & \begin{tabular}{|l|l|}
0.19 \\
\end{tabular} & 1.04 & 0.24 & 0.82 & 0.36 \\
\hline River 9 (1.5) & 27-Aug-01 & 0.26 & 0.07 & 0.37 & 0.15 & 0.002 & 0.008 & 0.032 & 0.09 & 0.22 & 0.06 & 0.23 & \begin{tabular}{|l|l|}
0.12 \\
\end{tabular} & 0.49 & 0.09 & 0.63 & \begin{tabular}{|l|l|}
0.21 \\
\end{tabular} & 0.66 & 0.17 & 0.70 & 0.36 \\
\hline DR River $9(0.25)$ & 27-Aug-01 & 4.70 & 0.86 & 4.19 & 0.48 & 0.288 & 0.066 & 0.18 & \begin{tabular}{|l|l|}
0.12 \\
\end{tabular} & 4.26 & 0.78 & 3.52 & \begin{tabular}{|l|l|}
0.44 \\
\end{tabular} & 9.25 & 1.16 & 7.89 & \begin{tabular}{|l|}
0.66 \\
\end{tabular} & 12.84 & 2.33 & \begin{tabular}{|l|}
10.59 \\
\end{tabular} & 1.31 \\
\hline DR River $9(0.5)$ & 27-Aug-01 & 5.27 & 0.97 & 5.52 & 0.6 & 0.374 & 0.083 & 0.3 & 0.16 & 4.62 & 0.85 & 4.94 & \begin{tabular}{|l|}
0.56 \\
\end{tabular} & 10.26 & 1.29 & 10.76 & \begin{tabular}{|l|l|}
0.84 \\
\end{tabular} & 13.96 & 2.54 & 14.88 & 1.67 \\
\hline DR River $9(1.0)$ & 27-Aug-01 & 1.67 & 0.32 & 2.07 & 0.33 & 0.078 & 0.026 & 0.16 & \begin{tabular}{|l|l|}
0.12 \\
\end{tabular} & 1.57 & 0.30 & 1.95 & \begin{tabular}{|l|}
0.32 \\
\end{tabular} & 3.32 & 0.44 & 4.18 & \begin{tabular}{|l|l|}
0.48 \\
\end{tabular} & 4.72 & 0.90 & 5.89 & 0.96 \\
\hline DR River 9 (1.5) & 27-Aug-01 & 0.32 & 0.07 & 0.33 & 0.13 & 0.010 & 0.010 & 0.028 & 0.056 & 0.25 & 0.06 & 0.25 & 0.12 & \begin{tabular}{l|l|}
0.58 \\
\end{tabular} & 0.09 & 0.61 & 0.19 & 0.76 & 0.18 & 0.76 & 0.36 \\
\hline River 9 to 11 & 27-Aug-01 & 0.54 & 0.11 & 0.37 & 0.20 & 0.019 & 0.012 & 0.05 & \begin{tabular}{|l|}
0.10 \\
\end{tabular} & 0.54 & 0.11 & 0.56 & \begin{tabular}{|l|l|}
0.23 \\
\end{tabular} & 1.10 & 0.16 & 0.98 & \begin{tabular}{|l|l|}
0.32 \\
\end{tabular} & 1.63 & 0.33 & 1.69 & 0.69 \\
\hline $\begin{array}{l}\text { River } 11(0.25) \\
\end{array}$ & 27-Aug-01 & \begin{tabular}{c|}
5.05 \\
\end{tabular} & 0.92 & & & 0.248 & 0.058 & & & 4 & 0.82 & & & \begin{tabular}{l|l}
9.78 \\
\end{tabular} & 1.23 & & & 13.48 & 2.45 & & \\
\hline River $11(0.5)$ & 27-Aug-01 & 0.70 & 0.14 & & & 0.027 & 0.014 & & & 0.63 & 0.13 & & & 1.36 & 0.19 & & & 1.88 & 0.39 & & \\
\hline River $11(1.0)$ & 27-Aug-01 & 1.39 & 0.27 & & & 0.058 & 0.021 & & & \begin{tabular}{l|l}
1.28 \\
\end{tabular} & 0.24 & & & 2.73 & 0.36 & & & 3.85 & 0.72 & & \\
\hline River 11 (1.5) & 27-Aug-01 & 0.72 & 0.15 & & & 0.032 & 0.016 & & & 0.64 & 0.13 & & & 1.39 & 0.20 & & & 1.92 & 0.39 & & \\
\hline DR River $11(0.25)$ & 27-Aug-01 & 2.59 & 0.49 & & & 0.094 & 0.030 & & & 2.48 & 0.47 & & & 5.16 & 0.68 & & & 7.44 & 1.40 & & \\
\hline DR River $11(0.5)$ & 27-Aug-01 & 0.65 & 0.13 & & & 0.025 & 0.014 & & & 0.61 & 0.13 & & & 1.29 & 0.18 & & & 1.83 & 0.39 & & \\
\hline DR River $11(1.0)$ & 27-Aug-01 & 0.49 & 0.11 & & & 0.031 & 0.018 & & & 0.44 & 0.10 & & & 0.96 & 0.15 & & & 1.32 & 0.30 & & \\
\hline DR River 11 (1.5) & 27-Aug-01 & 0.38 & 0.09 & & & 0.017 & 0.013 & & & 0.29 & 0.07 & & & \begin{tabular}{l|l|}
0.69 \\
\end{tabular} & 0.11 & & & 0.86 & 0.21 & & \\
\hline River $14(0.25)$ & 27-Aug-01 & 0.46 & 0.10 & & & 0.009 & 0.011 & & & 0.45 & 0.10 & & & 0.92 & 0.14 & & & 1.36 & 0.30 & & \\
\hline River $14(0.5)$ & 27-Aug-01 & 0.43 & 0.09 & & & 0.022 & 0.013 & & & 0.43 & 0.09 & & & 0.89 & 0.13 & & & 1.30 & 0.28 & & \\
\hline River $14(1.0)$ & 27-Aug-01 & 0.54 & 0.11 & & & 0.012 & 0.010 & & & 0.41 & 0.09 & & & 0.96 & 0.14 & & & 1.22 & 0.27 & & \\
\hline River 14 (1.5) & 27-Aug-01 & 0.37 & 0.08 & & & 0.007 & 0.008 & & & 0.28 & 0.07 & & & 0.66 & 0.11 & & & 0.83 & 0.19 & & \\
\hline Vernita $(0.25)$ & $27-A u g-01$ & 0.22 & 0.05 & 0.19 & 0.06 & 0.004 & 0.007 & 0.013 & \begin{tabular}{|c|}
0.028 \\
\end{tabular} & 0.22 & 0.05 & 0.24 & \begin{tabular}{|l|l|}
0.07 \\
\end{tabular} & 0.44 & 0.08 & 0.44 & \begin{tabular}{|l|l|}
0.10 \\
\end{tabular} & 0.66 & 0.16 & \begin{tabular}{l|l}
0.72 \\
\end{tabular} & 0.21 \\
\hline Vernita $(0.5)$ & 27-Aug-01 & 0.21 & 0.05 & & & 0.001 & 0.005 & & & 0.16 & 0.04 & & & 0.37 & 0.07 & & & 0.47 & 0.13 & & \\
\hline Vernita (1.0) & 27-Aug-01 & 0.37 & 0.08 & & & 0.012 & 0.010 & & & 0.34 & 0.08 & & & 0.72 & 0.12 & & & 1.03 & 0.23 & & \\
\hline Vernita (1.5) & 27-Aug-01 & 0.23 & 0.06 & & & 0.010 & 0.010 & & & 0.15 & 0.04 & & & 0.38 & 0.08 & & & 0.45 & 0.13 & & \\
\hline
\end{tabular}


Table B.1. (contd)

\begin{tabular}{|c|c|c|c|c|c|c|c|c|c|c|c|c|c|}
\hline \multirow{3}{*}{$\begin{array}{l}\text { Sample Location } \\
\text { (depth, m) }\end{array}$} & \multirow{3}{*}{$\begin{array}{l}\text { Collection } \\
\text { Date }\end{array}$} & \multicolumn{4}{|c|}{ "Thorium-228 (pCi/L) } & \multicolumn{4}{|c|}{ Thorium-230 (pCi/L) } & \multicolumn{4}{|c|}{ "Thorium-232 (pCi/L) } \\
\hline & & \multicolumn{2}{|c|}{ SESP } & \multicolumn{2}{|c|}{ WDOH } & \multicolumn{2}{|c|}{ SESP } & \multicolumn{2}{|c|}{ WDOH } & \multicolumn{2}{|c|}{ SESP } & \multicolumn{2}{|c|}{$\mathrm{WDOH}$} \\
\hline & & Result & Error & Result & Error & Result & Error & Result & Error & Result & Error & Result & Error \\
\hline River $7(0.25)$ & 27-Aug-01 & & & & & & & & & & & & \\
\hline River $7(0.5)$ & 27-Aug-01 & & & & & & & & & & & & \\
\hline River 7 (1.0) & 27-Aug-01 & & & & & & & & & & & & \\
\hline River 7 (1.5) & 27-Aug-01 & & & & & & & & & & & & \\
\hline DR River $7(0.25)$ & 27-Aug-01 & & & & & & & & & & & & \\
\hline DR River $7(0.5)$ & 27-Aug-01 & & & & & & & & & & & & \\
\hline DR River 7 (1.0) & 27-Aug-01 & & & & & & & & & & & & \\
\hline DR River 7 (1.5) & 27-Aug-01 & & & & & & & & & & & & \\
\hline River 7 to 9 & 27-Aug-01 & & & & & & & & & & & & \\
\hline River 9 (0.25) & 27-Aug-01 & & & & & & & & & & & & \\
\hline River 9 $(0.5)$ & 27-Aug-01 & & & & & & & & & & & & \\
\hline River 9 (1.0) & 27-Aug-01 & & & & & & & & & & & & \\
\hline River 9(1.5) & 27-Aug-01 & & & & & & & & & & & & \\
\hline DR River $9(0.25)$ & 27-Aug-01 & & & & & & & & & & & & \\
\hline DR River $9(0.5)$ & 27-Aug-01 & & & & & & & & & & & & \\
\hline DR River 9 (1.0) & 27-Aug-01 & & & & & & & & & & & & \\
\hline DR River 9 (1.5) & 27-Aug-01 & & & & & & & & & & & & \\
\hline River 9 to 11 & 27-Aug-01 & & & & & & & & & & & & \\
\hline River 11 (0.25) & 27-Aug-01 & & & & & & & & & & & & \\
\hline River $11(0.5)$ & 27-Aug-01 & & & & & & & & & & & & \\
\hline River $11(1.0)$ & 27-Aug-01 & & & & & & & & & & & & \\
\hline River 11 (1.5) & 27-Aug-01 & & & & & & & & & & & & \\
\hline DR River $11(0.25)$ & 27-Aug-01 & & & & & & & & & & & & \\
\hline DR River $11(0.5)$ & 27-Aug-01 & & & & & & & & & & & & \\
\hline DR River $11(1.0)$ & 27-Aug-01 & & & & & & & & & & & & \\
\hline DR River 11 (1.5) & 27-Aug-01 & & & & & & & & & & & & \\
\hline River $14(0.25)$ & 27-Aug-01 & & & & & & & & & & & & \\
\hline River $14(0.5)$ & 27-Aug-01 & & & & & & & & & & & & \\
\hline River $14(1.0)$ & 27-Aug-01 & & & & & & & & & & & & \\
\hline River 14 (1.5) & 27-Aug-01 & & & & & & & & & & & & \\
\hline Vernita $(0.25)$ & 27-Aug-01 & & & -0.006 & 0.053 & & & -0.03 & 0.09 & & & -0.006 & 0.02 \\
\hline Vernita $(0.5)$ & 27-Aug-01 & & & & & & & & & & & & \\
\hline Vernita (1.0) & 27-Aug-01 & & & & & & & & & & & & \\
\hline Vernita (1.5) & 27-Aug-01 & & & & & & & & & & & & \\
\hline
\end{tabular}


Table B.1. (contd)

\begin{tabular}{|c|c|c|c|c|c|c|c|c|c|c|c|c|c|}
\hline \multirow{3}{*}{\begin{tabular}{|c} 
Sample Location \\
(depth, m)
\end{tabular}} & \multirow{3}{*}{$\begin{array}{l}\text { Collection } \\
\text { Date }\end{array}$} & \multicolumn{4}{|c|}{ Tritium $(\mathrm{pCi} / \mathrm{L})$} & \multicolumn{4}{|c|}{ Strontium-90 (pCi/L) } & \multicolumn{4}{|c|}{ Technetium-99 (pCi/L) } \\
\hline & & \multicolumn{2}{|c|}{ SESP } & \multicolumn{2}{|c|}{ WDOH } & \multicolumn{2}{|c|}{ SESP } & \multicolumn{2}{|c|}{ WDOH } & \multicolumn{2}{|c|}{ SESP } & \multicolumn{2}{|c|}{ WDOH } \\
\hline & & Result & Error & Result & Error & Result & Error & Result & Error & Result & Error & Result & Error \\
\hline River $7(0.25)$ & 27-Aug-01 & & & 4540 & 140 & & & -0.2 & 0.7 & & & 7.0 & 1.0 \\
\hline River $7(0.5)$ & 27-Aug-01 & & & 2350 & 100 & & & & & & & & \\
\hline River 7 (1.0) & 27-Aug-01 & & & 1290 & 80 & & & & & & & & \\
\hline River 7 (1.5) & 27-Aug-01 & & & 1070 & 70 & & & & & & & & \\
\hline DR River $7(0.25)$ & 27-Aug-01 & & & 1160 & 70 & & & & & & & & \\
\hline DR River $7(0.5)$ & 27-Aug-01 & & & 610 & 60 & & & & & & & & \\
\hline DR River 7 (1.0) & 27-Aug-01 & & & 580 & 60 & & & & & & & & \\
\hline DR River 7 (1.5) & 27-Aug-01 & & & 390 & 60 & & & & & & & & \\
\hline River 7 to 9 & 27-Aug-01 & & & 390 & 60 & & & & & & & & \\
\hline River 9 (0.25) & 27-Aug-01 & & & 4850 & 130 & & & -0.1 & 0.6 & & & 15.0 & 1.0 \\
\hline River 9 (0.5) & 27-Aug-01 & & & 540 & 60 & & & & & & & & \\
\hline River 9(1.0) & 27-Aug-01 & & & 250 & 50 & & & & & & & & \\
\hline River 9 (1.5) & 27-Aug-01 & & & 130 & 40 & & & & & & & & \\
\hline DR River $9(0.25)$ & 27-Aug-01 & & & 810 & 60 & & & & & & & & \\
\hline DR River 9 (0.5) & 27-Aug-01 & & & 890 & 70 & & & & & & & & \\
\hline DR River 9 (1.0) & 27-Aug-01 & & & 520 & 60 & & & & & & & & \\
\hline DR River 9 (1.5) & 27-Aug-01 & & & 220 & 50 & & & & & & & & \\
\hline River 9 to 11 & 27-Aug-01 & & & 110 & 40 & & & & & & & & \\
\hline River $11(0.25)$ & 27-Aug-01 & & & 450 & 50 & & & -0.2 & 0.9 & & & 1.3 & 1.1 \\
\hline River $11(0.5)$ & 27-Aug-01 & & & 170 & 50 & & & & & & & & \\
\hline River 11(1.0) & 27-Aug-01 & & & 120 & 40 & & & & & & & & \\
\hline River $11(1.5)$ & 27-Aug-01 & & & 70 & 40 & & & & & & & & \\
\hline DR River $11(0.25)$ & 27-Aug-01 & & & 320 & 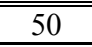 & & & & & & & & \\
\hline DR River $11(0.5)$ & 27-Aug-01 & & & 80 & 40 & & & & & & & & \\
\hline DR River $11(1.0)$ & 27-Aug-01 & & & 70 & 40 & & & & & & & & \\
\hline DR River 11 (1.5) & 27-Aug-01 & & & 70 & 40 & & & & & & & & \\
\hline River $14(0.25)$ & 27-Aug-01 & & & 50 & 40 & & & & & & & & \\
\hline River $14(0.5)$ & 27-Aug-01 & & & 30 & 40 & & & & & & & & \\
\hline River 14(1.0) & 27-Aug-01 & & & 30 & 40 & & & & & & & & \\
\hline River 14 (1.5) & 27-Aug-01 & & & 30 & 40 & & & & & & & & \\
\hline Vernita $(0.25)$ & 27-Aug-01 & & & -50 & 40 & & & -0.1 & 0.6 & & & 0.1 & 1.1 \\
\hline Vernita (0.5) & 27-Aug-01 & & & -33 & 39 & & & & & & & & \\
\hline Vernita (1.0) & 27-Aug-01 & & & -47 & 37 & & & & & & & & \\
\hline Vernita (1.5) & 27-Aug-01 & & & -56 & 37 & & & & & & & & \\
\hline
\end{tabular}


Table B.2. Radionuclide Results for River Water Samples from Cross-River Transects and Near-Shore Samples at the 300 Area and Vernita Bridge

\begin{tabular}{|c|c|c|c|c|c|c|c|c|c|c|c|c|c|}
\hline \multirow[b]{3}{*}{ Sample Location } & \multirow{3}{*}{$\begin{array}{l}\text { Collection } \\
\text { Date }\end{array}$} & \multicolumn{4}{|c|}{$\begin{array}{c}\text { Tritium } \\
\text { as } \mathrm{pCi} / \mathrm{L}\end{array}$} & \multicolumn{4}{|c|}{$\begin{array}{l}\text { Strontium-90 } \\
\text { as pCi/L }\end{array}$} & \multicolumn{4}{|c|}{$\begin{array}{l}\text { Total Uranium } \\
\text { as pCi/L }\end{array}$} \\
\hline & & \multicolumn{2}{|c|}{ SESP } & \multicolumn{2}{|c|}{ WDOH } & \multicolumn{2}{|c|}{ SESP } & \multicolumn{2}{|c|}{ WDOH } & \multicolumn{2}{|c|}{ SESP } & \multicolumn{2}{|c|}{ WDOH } \\
\hline & & Result & Error & Result & Error & Result & Error & Result & Error & Result & Error & Result & Error \\
\hline \multicolumn{14}{|c|}{ 300 Area Cross River Transect at Hanford River Marker 43.1 (at 300 Area southern boundary) } \\
\hline 300 Station -1 HRM 43.1 & 13-Sep-01 & 43.3 & 7.2 & 16 & 39 & 0.074 & 0.039 & 0.4 & 0.9 & 0.438 & 0.074 & 0.39 & 0.10 \\
\hline 300 Station-2 HRM 43.1 & 13-Sep-01 & 48.7 & 8.2 & -15 & 37 & 0.071 & 0.034 & 0.6 & 0.8 & 0.426 & 0.074 & 0.56 & 0.11 \\
\hline 300 Station-3 HRM 43.1 & 13-Sep-01 & 29.7 & 6.2 & -22 & 37 & 0.057 & 0.032 & 0.2 & 0.7 & 0.414 & 0.072 & 0.46 & 0.11 \\
\hline 300 Station-5 HRM 43.1 & 13-Sep-01 & 33.9 & 6.5 & -19 & 37 & 0.063 & 0.032 & -0.1 & 0.7 & 0.482 & 0.083 & 0.47 & 0.11 \\
\hline 300 Station-7 HRM 43.1 & 13-Sep-01 & 30.4 & 6.3 & 1 & 40 & 0.054 & 0.031 & 0.7 & 0.8 & 0.417 & 0.075 & 0.65 & 0.14 \\
\hline 300 Station-10 HRM 43.1 & 13-Sep-01 & 32.5 & 6.7 & -22 & 39 & 0.063 & 0.035 & 0.3 & 0.7 & 1.78 & 0.249 & 1.60 & 0.25 \\
\hline \multicolumn{14}{|c|}{300 Area Near-Shore Samples (also see 300 Station-1 HRM 43.1, above) } \\
\hline 300 AREA SHR HRM 41.5 & 13-Sep-01 & 135 & 14 & 31 & 38 & 0.082 & 0.037 & -0.3 & 1.0 & 0.447 & 0.085 & 0.41 & 0.17 \\
\hline 300 AREA SHR HRM 42.2 & 13-Sep-01 & 547 & 50 & 414 & 53 & 0.076 & 0.036 & -0.1 & 0.4 & 0.656 & 0.104 & 0.70 & 0.21 \\
\hline 300 AREA SHR HRM 42.5 & 13-Sep-01 & 103 & 12 & 7 & 40 & 0.059 & 0.032 & -0.9 & 0.7 & 0.462 & 0.084 & 0.63 & 0.21 \\
\hline 300 AREA SHR HRM 42.9 & 13-Sep-01 & 48.7 & 7.7 & -21 & 37 & 0.068 & 0.033 & -0.4 & 0.5 & 0.470 & 0.080 & 0.56 & 0.18 \\
\hline \multicolumn{14}{|c|}{ Vernita Bridge Cross River Transects } \\
\hline Vernita Bridge-1 & 07-Sep-01 & 28 & 6.2 & & & 0.055 & 0.030 & & & 0.383 & 0.0720 & & \\
\hline Vernita Bridge-2 & 07-Sep-01 & 22 & 5.8 & & & 0.088 & 0.037 & & & 0.439 & 0.0832 & & \\
\hline Vernita Bridge-3 & 07-Sep-01 & 24 & 6.0 & & & 0.061 & 0.031 & & & 0.454 & 0.0897 & & \\
\hline Vernita Bridge-4 & 07-Sep-01 & 18 & 5.5 & & & 0.066 & 0.032 & & & 0.449 & 0.0813 & & \\
\hline
\end{tabular}


Table B.3. Radionuclides in Riverbank Spring Water from the 300 Area and Vernita Bridge

\begin{tabular}{|c|c|c|c|c|c|c|c|c|c|c|c|c|c|c|c|c|c|}
\hline \multirow{3}{*}{$\begin{array}{l}\text { Sample } \\
\text { Location }\end{array}$} & \multirow{3}{*}{$\begin{array}{c}\text { Collection } \\
\text { Date }\end{array}$} & \multicolumn{4}{|c|}{ Uranium-234 (pCi/L) } & \multicolumn{4}{|c|}{ Uranium-235 (pCi/L) } & \multicolumn{4}{|c|}{ Uranium-236 $^{(a)}(\mathrm{pCi} / \mathrm{L})$} & \multicolumn{4}{|c|}{ Uranium-238 (pCi/L) } \\
\hline & & \multicolumn{2}{|c|}{ SESP } & \multicolumn{2}{|c|}{ WDOH } & \multicolumn{2}{|c|}{ SESP } & \multicolumn{2}{|c|}{ WDOH } & \multicolumn{2}{|c|}{ SESP } & \multicolumn{2}{|c|}{ WDOH } & \multicolumn{2}{|c|}{ SESP } & \multicolumn{2}{|c|}{ WDOH } \\
\hline & & Result & Error & Result & Error & Result & Error & Result & Error & Result & Error & Result & Error & Result & Error & Result & Error \\
\hline Spring 7 & 27-Aug-01 & 14.6 & 2.7 & 13.8 & 0.5 & 0.615 & 0.13 & 0.9 & 0.1 & 0.289 & & & & 13.4 & 2.4 & 13.2 & 0.5 \\
\hline Spring 9 & 27-Aug-01 & 53.3 & 9.6 & 43.5 & 1 & 2.24 & 0.42 & 2.7 & 0.2 & 1.010 & & & & 47.5 & 8.6 & 44 & 1 \\
\hline Vernita Bridge & 14-Nov-01 & 0.25 & 0.06 & & & 0.003 & 0.005 & & & 0.002 & & & & 0.190 & 0.050 & & \\
\hline & & & & & & & & & & & & & & & & & \\
\hline \multirow{3}{*}{$\begin{array}{l}\text { Sample } \\
\text { Location }\end{array}$} & \multirow{3}{*}{$\begin{array}{c}\text { Collection } \\
\text { Date }\end{array}$} & \multicolumn{4}{|c|}{ Total Uranium (radiological pCi/L) } & \multicolumn{4}{|c|}{ Total Uranium (chemical $\mu \mathrm{g} / \mathrm{L}$ ) } & \multicolumn{4}{|c|}{ Gross Alpha (pCi/L) } & \multicolumn{4}{|c|}{ Gross Beta (pCi/L) } \\
\hline & & \multicolumn{2}{|c|}{ SESP $^{(\mathrm{b})}$} & WD & & SESI & & & $\mathrm{OH}$ & SES & & WD & & & ESP & WD & $\mathrm{OH}$ \\
\hline & & Result & Error & Result & Error & Result & Error & Result & Error & Result & Error & Result & Error & Result & Error & Result & Error \\
\hline Spring 7 & 27-Aug-01 & 28.62 & 3.61 & 27.90 & 0.71 & 40.27 & 6.05 & 39.80 & 3.56 & 27 & 7.9 & 35 & 8 & 16 & 3.2 & 18 & 3 \\
\hline Spring 9 & 27-Aug-01 & 103.04 & 12.90 & 90.20 & 1.43 & 142.76 & 15.07 & 132.53 & 4.16 & 86.8 & 21 & 110 & 10 & 32.7 & 5.4 & 39 & 3 \\
\hline Vernita Bridge & 14-Nov-01 & 0.44 & 0.08 & & & 0.57 & 3.07 & & & 4.20 & 1.80 & & & 8.35 & 1.80 & & \\
\hline & & Tritium ( & $\mathrm{Ci} / \mathrm{L})$ & & & Cobalt-60 & $(\mathrm{pCi} / \mathrm{L})$ & & & Strontiun & $-90(\mathrm{pC}$ & & & Techneti & ium-99 (pc & $\mathrm{Ci} / \mathrm{L})$ & \\
\hline Sample & Collection & SES & & WD & & SESP & & WDOH & & SE & & WD & & & ESP & & $\mathrm{OH}$ \\
\hline Location & Date & Result & Error & Result & Error & Result & Error & Result & Error & Result & Error & Result & Error & Result & Error & Result & Error \\
\hline Spring 7 & 27-Aug-01 & 6300 & 380 & 6210 & 150 & 0.559 & 2.5 & 1 & 1 & & & 0.8 & 0.8 & & & 11 & 1 \\
\hline Spring 9 & 27-Aug-01 & 8380 & 460 & 7400 & 200 & 0.823 & 2.5 & 0.4 & 0.5 & & & -0.3 & 0.9 & & & 34 & 3 \\
\hline Vernita Bridge & 14-Nov-01 & 35.40 & 6.90 & & & -0.357 & 2.700 & & & 0.026 & 0.061 & & & & & & \\
\hline & & & & & & & & & & & & & & & & & \\
\hline & & & henium- & $106(\mathrm{pCi}$ & & & Iodine-12 & $29(\mathrm{pCi} / \mathrm{L}$ & & Cesium-1 & $7(\mathrm{pCi} /$ & & & Thorium & 1-228 (pCi & i/L) & \\
\hline Sample & Collection & SES & & WD & & SES & & & $\mathrm{OH}$ & SE & & WD & & SESP & & WDOH & \\
\hline Location & Date & Result & Error & Result & Error & Result & Error & Result & Error & Result & Error & Result & Error & Result & Error & Result & Error \\
\hline \begin{tabular}{|l} 
Spring 7 \\
\end{tabular} & 27-Aug-01 & -12.7 & 19 & & & 0.0034 & 0.00040 & & & 0.269 & 2.4 & -1 & 1 & 0.0837 & 0.033 & 0.08 & 0.05 \\
\hline Spring 9 & 27-Aug-01 & -4.34 & 24 & & & 0.0041 & 0.00047 & & & -0.678 & 2.9 & -0.2 & 0.5 & 0.00472 & 0.0086 & 0.03 & 0.04 \\
\hline Vernita Bridge & 14-Nov-01 & 9.04 & 25.00 & & & & & & & -1.22 & 2.2 & & & 0.023 & 0.016 & & \\
\hline & & & & & & & & & & & & & & & & & \\
\hline & & & orium-2 & $30(\mathrm{pCi} / \mathrm{l}$ & & & horium-2 & $232(\mathrm{pCi} / 1$ & & & & & & & & & \\
\hline Sample & Collection & SES & & WD & & SES & & WD & $\mathrm{OH}$ & & & & & & & & \\
\hline Location & Date & Result & Error & Result & Error & Result & Error & Result & Error & & & & & & & & \\
\hline \begin{tabular}{|l|} 
Spring 7 \\
\end{tabular} & 27-Aug-01 & 0.0542 & 0.025 & -0.006 & 0.059 & 0.0871 & 0.034 & 0.06 & 0.03 & & & & & & & & \\
\hline Spring 9 & 27-Aug-01 & \begin{tabular}{|l|}
0.00303 \\
\end{tabular} & 0.0056 & 0.100 & 0.080 & 0.000378 & 0.0043 & 0 & 0.02 & & & & & & & & \\
\hline Vernita Bridge & 14-Nov-01 & \begin{tabular}{|l|}
0.0059 \\
\end{tabular} & 0.0082 & & & 0.010 & 0.013 & & & & & & & & & & \\
\hline & & & & & & & & & & & & & & Conve & ersion Fact & tors for $\mathrm{U}$ & ranium \\
\hline (a) ICP-MS da & a, see Appenc & $\operatorname{dix~B,~Tab~}$ & e B.4. & & & & & & & & & & & Isotope & $\mathrm{pCi} / \mu \mathrm{g}$ & & $\mathrm{pCi}$ \\
\hline (b) SESP Total & Uranium $=\mathrm{S}$ & um of U-2 & $34, \mathrm{U}-23$ & , and $\mathrm{U}_{-}$ & & & & & & & & & & U-234 & 6243.93 & 0.00 & 0160 \\
\hline (c) Vernita Bri & lge sample fo & r U-236 b & ckgroun & was rive & water. & & & & & & & & & U-235 & 2.1624 & 0.46 & 2449 \\
\hline Shaded cells ind & cate no samp & les collect & & & & & & & & & & & & U-238 & 0.33517 & 2.98 & 3543 \\
\hline
\end{tabular}


Table B.4. ICP-MS Analysis Results for Sediment, River Water, and Riverbank Spring Water (results as dry weight are presented in both chemical and radiological units)

\begin{tabular}{|c|c|c|c|c|c|c|}
\hline Media & Location & $\begin{array}{c}\mathrm{U}-234 \\
(\mu \mathrm{g} / \mathrm{kg})\end{array}$ & $\begin{array}{c}\text { U-235 } \\
(\mu \mathrm{g} / \mathrm{kg})\end{array}$ & $\begin{array}{c}\mathrm{U}-236 \\
(\mu \mathrm{g} / \mathrm{kg})\end{array}$ & $\begin{array}{c}\text { U-238 } \\
(\mu \mathrm{g} / \mathrm{kg})\end{array}$ & $\begin{array}{c}\text { Total U ppb } \\
(\mu \mathrm{g} / \mathbf{k g})\end{array}$ \\
\hline Sediment & Vernita Br. & 0.010 & 1.24 & $\mathrm{~N} / \mathrm{D}$ & 187 & 188 \\
\hline Sediment & 7 & 0.144 & 18.7 & 0.371 & 2,340 & 2,360 \\
\hline Sediment & 9 & 0.236 & 30.8 & 0.608 & 3,790 & 3,820 \\
\hline Sediment & 11 & 0.236 & 30.4 & 0.598 & 3,790 & 3,820 \\
\hline Sediment & 11 (duplicate) & 0.230 & 30.4 & 0.592 & 3,790 & 3,820 \\
\hline \multirow[t]{2}{*}{ Sediment } & 14 & 0.011 & 1.33 & 0.00048 & 151 & 152 \\
\hline & & $(\mu \mathrm{g} / \mathrm{L})$ & $(\mu \mathrm{g} / \mathrm{L})$ & $(\mu \mathrm{g} / \mathrm{L})$ & $(\mu \mathrm{g} / \mathrm{L})$ & $(\mu \mathrm{g} / \mathrm{L})$ \\
\hline River & Vernita Br.-1 & 0.00002 & 0.00227 & 0.000038 & 0.307 & 0.31 \\
\hline River & Vernita Br.-2 & 0.00003 & 0.00292 & $\mathrm{~N} / \mathrm{D}$ & 0.394 & 0.40 \\
\hline Seep & 7 & 0.00165 & 0.218 & 0.00445 & 27.5 & 27.7 \\
\hline Seep & 9 & 0.00617 & 0.822 & 0.0155 & 102 & 102 \\
\hline Seep & 9 (duplicate) & 0.00617 & 0.822 & 0.0161 & 102 & 102 \\
\hline Media & Location & $\begin{array}{c}\mathrm{U}-234 \\
(\mathrm{pCi} / \mathrm{g})\end{array}$ & $\begin{array}{c}\mathrm{U}-235 \\
(\mathrm{pCi} / \mathrm{g})\end{array}$ & $\begin{array}{c}\mathrm{U}-236 \\
(\mathrm{pCi} / \mathrm{g})\end{array}$ & $\begin{array}{c}\mathrm{U}-238 \\
(\mathrm{pCi} / \mathrm{g})\end{array}$ & $\begin{array}{c}\text { Total U ppb } \\
\text { (pCi/g) }\end{array}$ \\
\hline Sediment & Vernita Br. & 0.064 & 0.0027 & N/D & 0.063 & 0.130 \\
\hline Sediment & 7 & 0.896 & 0.0404 & 0.0241 & 0.785 & 1.74 \\
\hline Sediment & 9 & 1.470 & 0.0665 & 0.0394 & 1.271 & 2.85 \\
\hline Sediment & 11 & 1.473 & 0.0658 & 0.0388 & 1.271 & 2.85 \\
\hline Sediment & 11 (duplicate) & 1.433 & 0.0658 & 0.0384 & 1.271 & 2.81 \\
\hline \multirow[t]{2}{*}{ Sediment } & 14 & 0.071 & 0.0029 & 0.00003 & 0.051 & 0.124 \\
\hline & & $(\mathrm{pCi} / \mathrm{L})$ & $(\mathrm{pCi} / \mathbf{L})$ & $(\mathrm{pCi} / \mathrm{L})$ & $(\mathrm{pCi} / \mathbf{L})$ & $(\mathrm{pCi} / \mathrm{L})$ \\
\hline River & Vernita Br.-1 & 0.106 & 0.00491 & 0.00246 & 0.103 & 0.216 \\
\hline River & Vernita Br.-2 & 0.175 & 0.00631 & N/D & 0.132 & 0.313 \\
\hline Seep & 7 & 10.3 & 0.471 & 0.289 & 9.22 & 20.3 \\
\hline Seep & 9 & 38.5 & 1.78 & 1.01 & 34.0 & 75.3 \\
\hline Seep & 9 (duplicate) & 38.5 & 1.78 & 1.04 & 34.0 & 75.4 \\
\hline Media & Location & $\begin{array}{c}\text { U-234 } \\
\text { (Wt. \%) }\end{array}$ & $\begin{array}{c}\text { U-235 } \\
(\text { Wt. \%) }\end{array}$ & $\begin{array}{c}\text { U-236 } \\
\text { (Wt. \%) }\end{array}$ & $\begin{array}{c}\text { U-238 } \\
\text { (Wt. \%) }\end{array}$ & $\begin{array}{l}\text { Total U } \\
\text { (Wt. \%) }\end{array}$ \\
\hline Sediment & Vernita Br. & 0.00548 & 0.660 & ND & 99.5 & 100 \\
\hline Sediment & 7 & 0.00608 & 0.791 & 0.0157 & 99.2 & 100 \\
\hline Sediment & 9 & 0.00616 & 0.805 & 0.0159 & 99.2 & 100 \\
\hline Sediment & 11 & 0.00617 & 0.795 & 0.0156 & 99.2 & 100 \\
\hline Sediment & 11 (duplicate) & 0.00600 & 0.796 & 0.0155 & 99.2 & 100 \\
\hline Sediment & 14 & 0.00743 & 0.873 & 0.00032 & 99.3 & 100 \\
\hline
\end{tabular}


Table B.4. (contd)

\begin{tabular}{|c|c|c|c|c|c|c|}
\hline Media & Location & $\begin{array}{c}\text { U-234 } \\
\text { (Wt. \%) }\end{array}$ & $\begin{array}{c}\text { U-235 } \\
(\text { Wt. \%) }\end{array}$ & $\begin{array}{c}\text { U-236 } \\
\text { (Wt. \%) }\end{array}$ & $\begin{array}{c}\text { U-238 } \\
(\text { Wt. \%) }\end{array}$ & $\begin{array}{c}\text { Total U } \\
(\text { Wt. \%) }\end{array}$ \\
\hline River & Vernita Br.-1 & 0.00550 & 0.735 & 0.01230 & 99.4 & 100 \\
\hline River & Vernita Br.-2 & 0.00707 & 0.737 & ND & 99.4 & 100 \\
\hline Seep & 7 & 0.00595 & 0.785 & 0.01605 & 99.2 & 100 \\
\hline Seep & 9 & 0.00603 & 0.803 & 0.01515 & 99.2 & 100 \\
\hline Seep & 9 & 0.00603 & 0.803 & 0.01574 & 99.2 & 100 \\
\hline \multicolumn{2}{|c|}{ Isotope Conversion Factors } & U-234 & U-235 & U-236 & U-238 & \\
\hline & $\mathrm{pCi} / \mu \mathrm{g}$ & 6243.93 & 2.1624 & 64.872 & 0.335172 & \\
\hline
\end{tabular}


Table B.5. Radionuclides in Shallow Groundwater Samples from the 300 Area Near-Shore

\begin{tabular}{|c|c|c|c|c|c|c|c|c|c|c|c|c|c|c|c|c|c|}
\hline \multirow[b]{3}{*}{ Sample Location } & \multirow{3}{*}{$\begin{array}{l}\text { Collection } \\
\text { Date }\end{array}$} & \multicolumn{4}{|c|}{ Uranium-234 (pCi/L) } & \multicolumn{4}{|c|}{ Uranium-235 (pCi/L) } & \multicolumn{4}{|c|}{ Uranium-238 (pCi/L) } & \multicolumn{4}{|c|}{ Total Uranium (pCi/L) } \\
\hline & & \multicolumn{2}{|c|}{ SESP } & \multicolumn{2}{|c|}{ WDOH } & \multicolumn{2}{|c|}{ SESP } & \multicolumn{2}{|c|}{ WDOH } & \multicolumn{2}{|c|}{ SESP } & \multicolumn{2}{|c|}{ WDOH } & \multicolumn{2}{|c|}{ SESP } & \multicolumn{2}{|c|}{ WDOH } \\
\hline & & Result & Error & Result & Error & Result & Error & Result & Error & Result & Error & Result & Error & Result & Error & Result & Error \\
\hline $7-1(0.76 \mathrm{~m}, 2.5 \mathrm{ft})$ & 18-Sep-01 & 62.8 & 11 & & & 2.88 & 0.54 & & & 64.7 & 12 & & & 130.4 & 16.29 & & \\
\hline $7-1(1.2 \mathrm{~m}, 4 \mathrm{ft})$ & 18-Sep-01 & 32.3 & 5.9 & & & 1.21 & 0.24 & & & 31.2 & 5.7 & & & 64.7 & 8.21 & & \\
\hline $7-1(1.8 \mathrm{~m}, 6 \mathrm{ft})$ & 18-Sep-01 & 33.7 & 6.2 & & & 1.43 & 0.29 & & & 31.5 & 5.8 & & & 66.6 & 8.49 & & \\
\hline $7-2(0.6 \mathrm{~m}, 2 \mathrm{ft})$ & 18-Sep-01 & 32.2 & 5.9 & & & 1.43 & 0.28 & & & 30.9 & 5.6 & & & 64.5 & 8.14 & & \\
\hline $7-2(1.2 \mathrm{~m}, 4.2 \mathrm{ft})$ & 18-Sep-01 & 37.4 & 6.8 & & & 0.292 & 0.07 & & & 34.6 & 6.3 & & & 72.3 & 9.27 & & \\
\hline $9-1(0.6 \mathrm{~m}, 2 \mathrm{ft})$ & 17-Sep-01 & 35.7 & 6.5 & & & 1.7 & 0.33 & & & 31.6 & 5.8 & & & 69.0 & 8.72 & & \\
\hline $9-1(1.2 \mathrm{~m}, 4 \mathrm{ft})$ & 17-Sep-01 & 53.7 & 9.7 & & & 1.13 & 0.22 & & & 46.8 & 8.5 & & & 101.6 & 12.90 & & \\
\hline $9-2(0.6 \mathrm{~m}, 2 \mathrm{ft})$ & 17-Sep-01 & 56.6 & 10 & & & 2.38 & 0.45 & & & 51.8 & 9.4 & & & 110.8 & 13.73 & & \\
\hline $9-2(1.4 \mathrm{~m}, 4.5 \mathrm{ft})$ & 17-Sep-01 & 56.3 & 10 & & & 2.32 & 0.44 & & & 51.8 & 9.4 & & & 110.4 & 13.73 & & \\
\hline $9-3(1.7 \mathrm{~m}, 5.5 \mathrm{ft})$ & 17-Sep-01 & 70.5 & 13 & & & 4.25 & 0.79 & & & 67.9 & 12 & & & 142.7 & 17.71 & & \\
\hline \multirow[b]{3}{*}{ Sample Location } & \multirow{3}{*}{$\begin{array}{c}\text { Collection } \\
\text { Date }\end{array}$} & \multicolumn{4}{|c|}{ Tritium $(\mathrm{pCi} / \mathrm{L})$} & \multicolumn{4}{|c|}{ Technetium-99 (pCi/L) } & & & & & & & & \\
\hline & & \multicolumn{2}{|c|}{ SESP } & \multicolumn{2}{|c|}{ WDOH } & \multicolumn{2}{|c|}{ SESP } & \multicolumn{2}{|c|}{ WDOH } & & & & & & & & \\
\hline & & Result & Error & Result & Error & Result & Error & Result & Error & & & & & & & & \\
\hline $7-1(0.76 \mathrm{~m}, 2.5 \mathrm{ft})$ & 18-Sep-01 & 7,560 & 460 & & & & & & & & & & & & & & \\
\hline 7-1 (1.2 m, $4 \mathrm{ft})$ & 18-Sep-01 & 8,020 & 480 & & & 9.93 & 0.38 & & & & & & & & & & \\
\hline $7-1(1.8 \mathrm{~m}, 6 \mathrm{ft})$ & 18-Sep-01 & 8,390 & 490 & & & 25.90 & 0.75 & & & & & & & & & & \\
\hline $7-2(0.6 \mathrm{~m}, 2 \mathrm{ft})$ & 18-Sep-01 & 8,420 & 490 & & & 9.07 & 0.33 & & & & & & & & & & \\
\hline $7-2(1.2 \mathrm{~m}, 4.2 \mathrm{ft})$ & 18-Sep-01 & 8,660 & 500 & & & & & & & & & & & & & & \\
\hline $9-1(0.6 \mathrm{~m}, 2 \mathrm{ft})$ & 17-Sep-01 & 6,060 & 400 & & & 9.43 & 0.34 & & & & & & & & & & \\
\hline $9-1(1.2 \mathrm{~m}, 4 \mathrm{ft})$ & 17-Sep-01 & 7,590 & 460 & & & 20.20 & 0.43 & & & & & & & & & & \\
\hline $9-2(0.6 \mathrm{~m}, 2 \mathrm{ft})$ & 17-Sep-01 & 7,800 & 470 & & & 12.00 & 0.35 & & & & & & & & & & \\
\hline $9-2(1.4 \mathrm{~m}, 4.5 \mathrm{ft})$ & 17-Sep-01 & 7,620 & 460 & & & 11.40 & 0.72 & & & & & & & & & & \\
\hline $9-3(1.7 \mathrm{~m}, 5.5 \mathrm{ft})$ & 17-Sep-01 & 7,160 & 450 & & & 10.70 & 0.34 & & & & & & & & & & \\
\hline
\end{tabular}


Table B.6. Radionuclides in Sediment from the 300 Area Near-Shore and Vernita Bridge

\begin{tabular}{|c|c|c|c|c|c|c|c|c|c|c|c|c|c|c|c|c|c|}
\hline \multirow{3}{*}{$\begin{array}{l}\text { Sample } \\
\text { Location }\end{array}$} & \multirow{3}{*}{$\begin{array}{l}\text { Collection } \\
\text { Date }\end{array}$} & \multicolumn{4}{|c|}{ "Uranium-234 (pCi/g dry wt.) } & \multicolumn{4}{|c|}{ "Uranium-235 (pCi/g dry wt.) } & \multicolumn{4}{|c|}{ " Uranium-236 ${ }^{(\mathrm{a})}$ (pCi/g dry wt.) } & \multicolumn{4}{|c|}{ Uranium-238 (pCi/g dry wt.) } \\
\hline & & \multicolumn{2}{|c|}{ SESP } & \multicolumn{2}{|c|}{ WDOH } & \multicolumn{2}{|c|}{ SESP } & \multicolumn{2}{|c|}{ WDOH } & \multicolumn{2}{|c|}{ SESP } & \multicolumn{2}{|c|}{ WDOH } & \multicolumn{2}{|c|}{ SESP } & \multicolumn{2}{|c|}{ WDOH } \\
\hline & & Result & Error & Result & Error & Result & Error & Result & Error & Result & Error & Result & Error & Result & Error & Result & Error \\
\hline 7 & 27-Aug-01 & 2.71 & 0.49 & 2.71 & 0.16 & 0.102 & 0.026 & 0.14 & 0.04 & 0.024 & & & & 2.45 & 0.44 & 2.53 & 0.15 \\
\hline 9 & 27-Aug-01 & & & 4.2 & 0.2 & & & 0.27 & 0.05 & 0.039 & & & & & & 3.8 & 0.2 \\
\hline 11 & 27-Aug-01 & 1.85 & 0.34 & & & 0.0757 & 0.021 & & & 0.039 & & & & 1.79 & 0.33 & & \\
\hline 14 & 27-Aug-01 & 0.328 & 0.068 & & & 0.00987 & 0.0065 & & & 0.00003 & & & & 0.346 & 0.071 & & \\
\hline Vernita Bridge & 27-Aug-01 & 0.23 & 0.05 & 0.94 & 0.1 & 0.0055 & 0.0049 & 0.048 & 0.026 & ND & & & & 0.186 & 0.042 & 0.87 & 0.1 \\
\hline \multirow{3}{*}{$\begin{array}{l}\text { Sample } \\
\text { Location }\end{array}$} & \multirow{3}{*}{$\begin{array}{l}\text { Collection } \\
\text { Date }\end{array}$} & \multicolumn{4}{|c|}{ Total Uranium (radiological pCi/g) } & \multicolumn{4}{|c|}{ Total Uranium (chemical $\mu \mathrm{g} / \mathrm{g}$ ) } & \multicolumn{4}{|c|}{ Gross Alpha (pCi/g dry wt.) } & \multicolumn{4}{|c|}{ Gross Beta (pCi/g dry wt.) } \\
\hline & & \multicolumn{2}{|c|}{$\operatorname{SESP}^{(b)}$} & \multicolumn{2}{|c|}{ WDOH } & \multicolumn{2}{|c|}{ SESP } & \multicolumn{2}{|c|}{ WDOH } & \multicolumn{2}{|c|}{ SESP } & \multicolumn{2}{|c|}{ WDOH } & \multicolumn{2}{|c|}{ SESP } & \multicolumn{2}{|c|}{ WDOH } \\
\hline & & Result & Error & Result & Error & Result & Error & Result & Error & Result & Error & Result & Error & Result & Error & Result & Error \\
\hline 7 & 27-Aug-01 & 5.26 & 0.66 & 5.38 & 0.22 & 7.36 & 1.31 & 7.61 & 0.45 & & & & & 29.7 & 5.1 & & \\
\hline 9 & 27-Aug-01 & & & 8.27 & 0.29 & & & 11.46 & 0.60 & & & & & & & & \\
\hline 11 & 27-Aug-01 & 3.72 & 0.47 & & & 5.38 & 0.98 & & & & & & & 22.2 & 4.2 & & \\
\hline 14 & 27-Aug-01 & 0.68 & 0.10 & & & 1.04 & 0.21 & & & & & & & 20.9 & 4 & & \\
\hline Vernita Bridge & 27-Aug-01 & 0.42 & 0.07 & 1.86 & 0.14 & 0.56 & 0.13 & 2.62 & 0.30 & & & & & 33.3 & 5.7 & & \\
\hline & & Cob & alt-60 (p & i/g dry v & & Stron & tium-90 & $\mathrm{Ci} / \mathrm{g}$ dry & & Techn & tium-9 & $(\mathrm{pCi} / \mathrm{g} \mathrm{d}$ & y wt.) & Cesiu & m-137 & (pCi/g dry & wt.) \\
\hline Sample & Collection & $\mathrm{SE}$ & & WD & & SE & & WD & & $\mathrm{SE}$ & & WD & & $\mathrm{SE}$ & SP & WD & \\
\hline Location & Date & Result & Error & Result & Error & Result & Error & Result & Error & Result & Error & Result & Error & Result & Error & Result & Error \\
\hline 7 & 27-Aug-01 & 0.000667 & 0.0089 & 0 & 0.009 & 0.0117 & 0.05 & & & & & & & 0.0379 & 0.013 & 0.051 & 0.016 \\
\hline 9 & 27-Aug-01 & & & 0.013 & 0.006 & & & 0.026 & 0.007 & & & 0.3 & 0.3 & & & 0.23 & 0.03 \\
\hline 11 & 27-Aug-01 & & & 0.008 & 0.004 & & & & & & & & & & & 0.11 & 0.02 \\
\hline 14 & 27-Aug-01 & & & 0.006 & 0.007 & & & & & & & & & & & 0.066 & 0.014 \\
\hline Vernita Bridge & 27-Aug-01 & & & 0 & 0.005 & & & 0.003 & 0.005 & & & -0.05 & 0.21 & & & 0.006 & 0.006 \\
\hline
\end{tabular}


Table B.6. (contd)

\begin{tabular}{|c|c|c|c|c|c|c|c|c|c|c|c|c|c|c|c|c|}
\hline \multirow{3}{*}{$\begin{array}{l}\text { Sample } \\
\text { Location }\end{array}$} & \multirow{3}{*}{$\begin{array}{l}\text { Collection } \\
\text { Date }\end{array}$} & \multicolumn{4}{|c|}{ Thorium-228 (pCi/g dry wt.) } & \multicolumn{4}{|c|}{ Thorium-230 (pCi/g dry wt.) } & \multicolumn{4}{|c|}{ Thorium-232 (pCi/g dry wt.) } & \multicolumn{3}{|c|}{ Conversion Factors for Uranium } \\
\hline & & \multicolumn{2}{|c|}{ SESP } & \multicolumn{2}{|c|}{ WDOH } & \multicolumn{2}{|c|}{ SESP } & \multicolumn{2}{|c|}{ WDOH } & \multicolumn{2}{|c|}{ SESP } & \multicolumn{2}{|c|}{ WDOH } & \multirow{2}{*}{\begin{tabular}{|l|} 
Isotope \\
U-234 \\
\end{tabular}} & \multirow{2}{*}{$\begin{array}{l}\mathrm{pCi} / \mu \mathrm{g} \\
6243.9\end{array}$} & \multirow{2}{*}{$\begin{array}{c}\mu \mathrm{g} / \mathrm{pCi} \\
0.000160\end{array}$} \\
\hline & & Result & Error & Result & Error & Result & Error & Result & Error & Result & Error & Result & Error & & & \\
\hline 7 & 27-Aug-01 & & & 1.7 & 0.3 & & & 1.2 & 0.2 & & & 1.5 & 0.3 & U-235 & 2.1624 & 0.462449 \\
\hline 9 & 27-Aug-01 & & & 1.1 & 0.3 & & & 0.7 & 0.2 & & & 1 & 0.2 & U-238 & 0.3352 & 2.983543 \\
\hline 11 & 27-Aug-01 & & & 1.1 & 0.2 & & & 0.6 & 0.1 & & & 1.2 & 0.2 & & & \\
\hline 14 & 27-Aug-01 & & & 1.2 & 0.2 & & & 0.8 & 0.2 & & & 0.8 & 0.2 & & & \\
\hline Vernita Bridge & 27-Aug-01 & & & 1.4 & 0.3 & & & 1.1 & 0.2 & & & 1.5 & 0.3 & & & \\
\hline
\end{tabular}


Table B.7. Radionuclides in Biota Samples from the 300 Area Near-Shore and Vernita Bridge Locations

\begin{tabular}{|c|c|c|c|c|c|c|c|c|c|c|c|c|c|c|c|c|c|}
\hline \multirow{3}{*}{$\begin{array}{l}\text { Sample } \\
\text { Location }\end{array}$} & \multirow{3}{*}{$\begin{array}{c}\text { Collection } \\
\text { Date }\end{array}$} & \multicolumn{4}{|c|}{ Tritium } & \multicolumn{4}{|c|}{ Strontium-90 } & \multicolumn{4}{|c|}{ Technetium-99 } & \multicolumn{4}{|c|}{ Cesium-137 } \\
\hline & & \multicolumn{2}{|c|}{ SESP } & \multicolumn{2}{|c|}{ WDOH } & \multicolumn{2}{|c|}{ SESP } & \multicolumn{2}{|c|}{ WDOH } & \multicolumn{2}{|c|}{ SESP } & \multicolumn{2}{|c|}{ WDOH } & \multicolumn{2}{|c|}{$\operatorname{SESP}^{(\mathrm{a})}$} & \multicolumn{2}{|c|}{ WDOH } \\
\hline & & Result & Error & Result & Error & Result & Error & Result & Error & Result & Error & Result & Error & Result & Error & Result & Error \\
\hline Crayfish & \multicolumn{5}{|c|}{ pCi/g (dry wt. unless noted) } & & & & & & & & & (wet wt.) & (wet wt.) & & \\
\hline 7 & 27-Aug-01 & & & & & 0.084 & 0.033 & & & 0.031 & 0.140 & & & -0.1350 & 0.0940 & & \\
\hline 9 & 27-Aug-01 & & & & & 0.114 & 0.038 & & & 0.121 & 0.140 & & & 0.0804 & 0.0950 & & \\
\hline 11 & 27-Aug-01 & & & & & 0.079 & 0.033 & & & 0.087 & 0.140 & & & -0.0512 & 0.1600 & & \\
\hline 14 & 27-Aug-01 & & & & & 0.267 & 0.073 & & & 0.031 & 0.140 & & & 0.0553 & 0.1300 & & \\
\hline Vernita Bridge & 28-Aug-01 & & & & & 0.137 & 0.044 & & & 0.0003 & 0.130 & & & 0.0817 & 0.1500 & & \\
\hline Sculpin & \multicolumn{5}{|c|}{ pCi/g (dry wt. unless noted) } & & & & & & & & & (wet wt.) & (wet wt.) & & \\
\hline 7 & 27-Aug-01 & & & & & 0.020 & 0.057 & & & 0.035 & 0.140 & & & -0.030 & 0.230 & & \\
\hline 9 & 27-Aug-01 & & & & & & & & & & & & & & & & \\
\hline 11 & 27-Aug-01 & & & & & 0.018 & 0.021 & & & -0.045 & 0.130 & & & -0.016 & 0.066 & & \\
\hline 14 & 27-Aug-01 & & & & & 0.010 & 0.020 & & & 0.097 & 0.340 & & & -0.013 & 0.062 & & \\
\hline Vernita Bridge & 28-Aug-01 & & & & & 0.006 & 0.022 & & & -0.022 & 0.130 & & & -0.021 & 0.054 & & \\
\hline Mouse & \multicolumn{5}{|c|}{ pCi/g (dry wt. unless noted) } & & & & & & & & & (wet wt.) & (wet wt.) & & \\
\hline 7 & 27-Aug-01 & & & & & & & & & 0.006 & 0.140 & & & -0.0097 & 0.0810 & & \\
\hline 9 & 27-Aug-01 & & & & & & & & & & & & & & & & \\
\hline 11 & 27-Aug-01 & & & & & & & & & -0.030 & 0.140 & & & -0.0032 & 0.1100 & & \\
\hline 14 & 27-Aug-01 & & & & & & & & & -0.021 & 0.140 & & & 0.0400 & 0.0940 & & \\
\hline Vernita Bridge & 28-Aug-01 & & & & & & & & & & & & & & & & \\
\hline Sweet Clover & \multicolumn{3}{|c|}{ pCi/g (dry wt. unless noted) } & (wet wt.) & (wet wt.) & & & & & & & & & & & & \\
\hline 7 & 27-Aug-01 & & & 290 & 50 & 0.094 & 0.046 & & & 0.204 & 0.150 & & & 0.0060 & 0.0160 & & \\
\hline 9 & 27-Aug-01 & & & 680 & 60 & 0.059 & 0.052 & 0.040 & 0.010 & 0.334 & 0.150 & 3.4 & 2.7 & 0.2710 & 0.0460 & & \\
\hline 11 & 27-Aug-01 & & & 360 & 50 & 0.094 & 0.043 & & & 0.316 & 0.150 & & & 0.2460 & 0.0400 & & \\
\hline 14 & 27-Aug-01 & & & 27 & 40 & 0.058 & 0.036 & & & 0.202 & 0.150 & & & 0.0616 & 0.1200 & & \\
\hline Vernita Bridge & 28-Aug-01 & & & -11 & 39 & 0.176 & 0.059 & 0.090 & 0.010 & -0.018 & 0.140 & 1.0 & 2.0 & 0.0804 & 0.1200 & & \\
\hline
\end{tabular}


Table B.7. (contd)

\begin{tabular}{|c|c|c|c|c|c|c|c|c|c|c|c|c|c|c|c|c|c|}
\hline \multirow{3}{*}{$\begin{array}{l}\text { Sample } \\
\text { Location }\end{array}$} & \multirow{3}{*}{$\begin{array}{l}\text { Collection } \\
\text { Date }\end{array}$} & \multicolumn{4}{|c|}{ Tritium } & \multicolumn{4}{|c|}{ Strontium-90 } & \multicolumn{4}{|c|}{ Technetium-99 } & \multicolumn{4}{|c|}{ Cesium-137 } \\
\hline & & \multicolumn{2}{|c|}{ SESP } & \multicolumn{2}{|c|}{ WDOH } & \multicolumn{2}{|c|}{ SESP } & \multicolumn{2}{|c|}{ WDOH } & \multicolumn{2}{|c|}{ SESP } & \multicolumn{2}{|c|}{ WDOH } & \multicolumn{2}{|c|}{$\operatorname{SESP}^{(\mathrm{a})}$} & \multicolumn{2}{|c|}{ WDOH } \\
\hline & & Result & Error & Result & Error & Result & Error & Result & Error & Result & Error & Result & Error & Result & Error & Result & Error \\
\hline Mulberry & \multicolumn{3}{|c|}{ pCi/g (dry wt. unless noted) } & (wet wt.) & (wet wt.) & & & & & & & & & & & & \\
\hline 7 & 27-Aug-01 & & & 2050 & 90 & 0.0011 & 0.0099 & & & 0.771 & 0.168 & & & 0.0011 & 0.0990 & & \\
\hline 9 & 27-Aug-01 & & & 3300 & 110 & 0.0024 & 0.0650 & 0.100 & 0.020 & 6.540 & 0.470 & -0.3 & 0.5 & 0.0024 & 0.0650 & & \\
\hline 11 & 27-Aug-01 & & & 1690 & 80 & 0.0343 & 0.0650 & & & 3.460 & 0.310 & & & 0.0343 & 0.0650 & & \\
\hline 14 & 27-Aug-01 & & & 35 & 43 & -0.0218 & 0.0860 & & & 0.183 & 0.150 & & & -0.0218 & 0.0860 & & \\
\hline Vernita Bridge & 28-Aug-01 & & & -20 & 37 & 0.0069 & 0.0120 & 0.100 & 0.020 & -0.009 & 0.140 & 0.40 & 2.90 & 0.0690 & 0.0120 & & \\
\hline Milfoil & \multicolumn{5}{|c|}{ pCi/g (dry wt. unless noted) } & & & (wet wt.) & (wet wt.) & & & (wet wt.) & (wet wt.) & & & & \\
\hline 7 & 27-Aug-01 & & & & & 0.087 & 0.036 & 0.003 & 0.002 & 0.220 & 0.150 & 0.18 & 0.52 & 0.0901 & 0.1400 & & \\
\hline 9 & 27-Aug-01 & & & & & & & & & & & & & & & & \\
\hline 11 & 27-Aug-01 & & & & & 0.078 & 0.034 & & & 0.309 & 0.150 & & & 0.0116 & 0.0680 & & \\
\hline 14 & 27-Aug-01 & & & & & 0.061 & 0.032 & & & 0.036 & 0.140 & & & 0.1210 & 0.1200 & & \\
\hline Vernita Bridge & 28-Aug-01 & & & & & 0.073 & 0.033 & 0.001 & 0.002 & 0.095 & 0.140 & 0.45 & 0.54 & -0.0102 & 0.1700 & & \\
\hline \multirow{3}{*}{$\begin{array}{l}\text { Sample } \\
\text { Location }\end{array}$} & \multirow{3}{*}{$\begin{array}{l}\text { Collection } \\
\text { Date }\end{array}$} & \multicolumn{4}{|c|}{ Uranium-234 } & \multicolumn{4}{|c|}{ Uranium-235 } & \multicolumn{4}{|c|}{ Uranium-238 } & \multicolumn{4}{|c|}{ Total Uranium } \\
\hline & & \multicolumn{2}{|c|}{ SESP } & \multicolumn{2}{|c|}{ WDOH } & \multicolumn{2}{|c|}{ SESP } & & $\mathrm{DOH}$ & SES & & & $\mathrm{OOH}$ & & $\mathrm{SP}^{(\mathrm{a})}$ & & \\
\hline & & Result & Error & Result & Error & Result & Error & Result & Error & Result & Error & Result & Error & Result & Error & Result & Error \\
\hline Crayfish & pCi/g (dry wt & unless 1 & oted) & & & & & & & & & & & & & & \\
\hline 7 & 27-Aug-01 & & & & & & & & & & & & & (c) & & & \\
\hline 9 & 27-Aug-01 & & & & & & & & & & & & & (c) & & & \\
\hline 11 & 27-Aug-01 & & & & & & & & & & & & & (c) & & & \\
\hline 14 & 27-Aug-01 & & & & & & & & & & & & & (c) & & & \\
\hline Vernita Bridge & 28-Aug-01 & & & & & & & & & & & & & (c) & & & \\
\hline Sculpin & pCi/g (dry wt & unless $\mathrm{r}$ & oted) & & & & & & & & & & & & & & \\
\hline 7 & 27-Aug-01 & & & & & & & & & & & & & (c) & & & \\
\hline 9 & 27-Aug-01 & & & & & & & & & & & & & (c) & & & \\
\hline 11 & 27-Aug-01 & & & & & & & & & & & & & (c) & & & \\
\hline 14 & 27-Aug-01 & & & & & & & & & & & & & (c) & & & \\
\hline Vernita Bridge & 28-Aug-01 & & & & & & & & & & & & & (c) & & & \\
\hline
\end{tabular}


Table B.7. (contd)

\begin{tabular}{|c|c|c|c|c|c|c|c|c|c|c|c|c|c|c|c|c|c|}
\hline \multirow{3}{*}{$\begin{array}{l}\text { Sample } \\
\text { Location }\end{array}$} & \multirow{3}{*}{$\begin{array}{l}\text { Collection } \\
\text { Date }\end{array}$} & \multicolumn{4}{|c|}{ Uranium-234 } & \multicolumn{4}{|c|}{ Uranium-235 } & \multicolumn{4}{|c|}{ Uranium-238 } & \multicolumn{4}{|c|}{ Total Uranium } \\
\hline & & \multicolumn{2}{|c|}{ SESP } & \multicolumn{2}{|c|}{ WDOH } & \multicolumn{2}{|c|}{ SESP } & \multicolumn{2}{|c|}{ WDOH } & \multicolumn{2}{|c|}{ SESP } & \multicolumn{2}{|c|}{ WDOH } & \multicolumn{2}{|c|}{$\operatorname{SESP}^{(a)}$} & \multicolumn{2}{|c|}{ WDOH } \\
\hline & & Result & Error & Result & Error & Result & Error & Result & Error & Result & Error & Result & Error & Result & Error & Result & Error \\
\hline Mouse & \multicolumn{5}{|c|}{ pCi/g (dry wt. unless noted) } & & & & & & & & & & & & \\
\hline 7 & 27-Aug-01 & & & & & & & & & & & & & (c) & & & \\
\hline 9 & 27-Aug-01 & & & & & & & & & & & & & (c) & & & \\
\hline 11 & 27-Aug-01 & & & & & & & & & & & & & (c) & & & \\
\hline 14 & 27-Aug-01 & & & & & & & & & & & & & (c) & & & \\
\hline Vernita Bridge & 28-Aug-01 & & & & & & & & & & & & & (c) & & & \\
\hline Sweet Clover & \multicolumn{5}{|c|}{ pCi/g (dry wt. unless noted) } & & & & & & & & & & & & \\
\hline 7 & 27-Aug-01 & & & 0.047 & 0.007 & & & 0.0020 & 0.0020 & & & 0.052 & 0.007 & 0.0790 & & 0.101 & 0.010 \\
\hline 9 & 27-Aug-01 & & & 0.012 & 0.004 & & & 0.0019 & 0.0016 & & & 0.009 & 0.003 & 0.0200 & & 0.023 & 0.005 \\
\hline 11 & 27-Aug-01 & & & 0.046 & 0.008 & & & 0.0022 & 0.0021 & & & 0.042 & 0.007 & 0.0330 & & 0.090 & 0.011 \\
\hline 14 & 27-Aug-01 & & & 0.025 & 0.003 & & & 0.0000 & 0.0010 & & & 0.025 & 0.006 & 0.0066 & & 0.050 & 0.007 \\
\hline Vernita Bridge & 28-Aug-01 & & & 0.014 & 0.007 & & & 0.0000 & 0.0010 & & & 0.011 & 0.006 & 0.0066 & & 0.025 & 0.009 \\
\hline Mulberry & \multicolumn{5}{|c|}{ pCi/g (dry wt. unless noted) } & & & & & & & & & & & & \\
\hline 7 & 27-Aug-01 & & & 0.0260 & 0.0070 & & & 0.0010 & 0.0010 & & & 0.020 & 0.006 & 0.0530 & & 0.047 & 0.009 \\
\hline 9 & 27-Aug-01 & & & 0.0230 & 0.0400 & & & 0.0000 & 0.0010 & & & 0.025 & 0.004 & 0.0790 & & 0.048 & 0.040 \\
\hline 11 & 27-Aug-01 & & & 0.0083 & 0.0049 & & & 0.0007 & 0.0018 & & & 0.013 & 0.005 & 0.0130 & & 0.022 & 0.007 \\
\hline 14 & 27-Aug-01 & & & -0.0020 & 0.0050 & & & -0.0003 & 0.0008 & & & -0.004 & 0.004 & 0.0066 & & -0.006 & 0.006 \\
\hline Vernita Bridge & 28-Aug-01 & & & -0.0020 & 0.0070 & & & 0.0000 & 0.0010 & & & -0.004 & 0.006 & 0.0066 & & -0.006 & 0.009 \\
\hline Milfoil & \multicolumn{3}{|c|}{ pCi/g (dry wt. unless noted) } & (wet wt.) & (wet wt.) & & & (wet wt.) & (wet wt.) & & & (wet wt.) & (wet wt.) & & & (wet wt.) & (wet wt.) \\
\hline 7 & 27-Aug-01 & & & 0.220 & 0.010 & & & 0.0110 & 0.0030 & & & 0.180 & 0.010 & 6.1 & & 0.411 & 0.023 \\
\hline 9 & 27-Aug-01 & & & & & & & & & & & & & & & & \\
\hline 11 & 27-Aug-01 & & & 0.488 & 0.013 & & & 0.0220 & 0.0030 & & & 0.403 & 0.012 & 5.1 & & 0.913 & 0.018 \\
\hline 14 & 27-Aug-01 & & & 0.115 & 0.006 & & & 0.0030 & 0.0010 & & & 0.096 & 0.006 & 4.2 & & 0.214 & 0.009 \\
\hline Vernita Bridge & 28-Aug-01 & & & 0.049 & 0.003 & & & 0.0019 & 0.0006 & & & 0.033 & 0.003 & 1.3 & & 0.084 & 0.004 \\
\hline \multicolumn{18}{|c|}{$\begin{array}{l}\text { (a) Result converted from ICP-MS ( } \mu \mathrm{g} / \mathrm{g} \text { ) to } \mathrm{pCi} / \mathrm{g} \text {. } \\
\text { (b) Total Uranium = Sum of U-234 + U235 + U-238. } \\
\text { (c) More than } 1 \text { sample; see Table } 4.7 \text {. } \\
\text { Shaded cells indicate no samples collected. }\end{array}$} \\
\hline
\end{tabular}


Table B.8. External Radiation Measurements on the Columbia River Near the 300 Area Shoreline

\begin{tabular}{|c|c|c|}
\hline Northing $(m)^{(a)}$ & Easting $(\mathrm{m})^{(\mathbf{a})}$ & Average $\mu R / h$ \\
\hline 116159.0 & 2594563.9 & 2.8 \\
\hline 115869.2 & 594665.2 & 3.1 \\
\hline 115511.9 & 594729.8 & 3.1 \\
\hline 116209.8 & 594559.4 & 3.1 \\
\hline 116649.2 & 594430.3 & 3.2 \\
\hline 116472.0 & 594465.8 & 3.2 \\
\hline 116767.9 & 594415.6 & 3.2 \\
\hline 116097.1 & 594584.4 & 3.3 \\
\hline 116232.4 & 594544.4 & 3.3 \\
\hline 115605.1 & 594721.1 & 3.3 \\
\hline 116438.2 & 594473.1 & 3.3 \\
\hline 116077.3 & 594586.6 & 3.4 \\
\hline 116757.3 & 594407.7 & 3.4 \\
\hline 116686.5 & 594421.3 & 3.5 \\
\hline 115915.7 & 594647.6 & 3.5 \\
\hline 116136.4 & 594570.4 & 3.5 \\
\hline 116053.4 & 594588.1 & 3.5 \\
\hline 115957.6 & 594616.9 & 3.5 \\
\hline 116574.7 & 594444.8 & 3.5 \\
\hline 115546.3 & 594732.0 & 3.5 \\
\hline 116308.2 & 594511.9 & 3.5 \\
\hline 115818.2 & 594676.6 & 3.6 \\
\hline 116612.5 & 594437.6 & 3.6 \\
\hline 116506.7 & 594458.3 & 3.6 \\
\hline 115889.8 & 594656.7 & 3.6 \\
\hline 116186.0 & 594562.9 & 3.7 \\
\hline 115984.3 & 594605.9 & 3.7 \\
\hline 116720.9 & 594407.8 & 3.7 \\
\hline 116810.0 & 594421.6 & 3.7 \\
\hline 116642.6 & 594410.2 & 3.8 \\
\hline 116540.6 & 594451.8 & 3.8 \\
\hline 115937.6 & 594636.9 & 3.8 \\
\hline 116809.1 & 594391.8 & 3.8 \\
\hline 116824.5 & 594403.6 & 3.8 \\
\hline 115583.0 & 594727.1 & 3.9 \\
\hline 116031.5 & 594595.0 & 3.9 \\
\hline 116337.7 & 594502.7 & 3.9 \\
\hline 116606.1 & 594413.9 & 3.9 \\
\hline 116783.8 & 594398.4 & 3.9 \\
\hline 115502.2 & 594732.6 & 4.0 \\
\hline 116404.3 & 594479.7 & 4.1 \\
\hline 116680.3 & 594414.1 & 4.1 \\
\hline 116369.4 & 594490.4 & 4.1 \\
\hline 116279.3 & 594520.0 & 4.2 \\
\hline 116115.4 & 594576.8 & 4.2 \\
\hline 116724.3 & 594414.7 & 4.3 \\
\hline 116568.9 & 594423.3 & 4.3 \\
\hline 116008.5 & 594598.8 & 4.4 \\
\hline 116254.8 & 594531.0 & 4.6 \\
\hline \multicolumn{3}{|c|}{$\begin{array}{l}\text { (a) NAD } 1983 \text { (Conus), U.S. State Plane 1983, WA Soutl } \\
\text { 4602, m, HAE. }\end{array}$} \\
\hline
\end{tabular}

\section{B.15}


Table B.9. External Radiation Measurements on the 300 Area Shoreline

\begin{tabular}{|c|c|c|c|c|c|}
\hline Northing $(m)^{(a)}$ & Easting $(\mathbf{m})^{(\mathbf{a})}$ & Average $\mu \mathbf{R} / \mathbf{h}$ & Northing $(m)^{(a)}$ & Easting $(\mathbf{m})^{(\mathbf{a})}$ & Average $\mu \mathrm{R} / \mathrm{h}$ \\
\hline 114428.9 & 594875.6 & 6.8 & 116351.6 & 594430.1 & 8.3 \\
\hline 114506.6 & 594863.8 & 7.0 & 115770.2 & 594578.8 & 8.3 \\
\hline 114520.5 & 594858.9 & 7.2 & 116242.8 & 594463.7 & 8.3 \\
\hline 114536.7 & 594855.8 & 7.4 & 115884.0 & 594561.8 & 8.3 \\
\hline 114402.5 & 594880.2 & 7.5 & 115515.1 & 594657.3 & 8.3 \\
\hline 114461.2 & 594875.4 & 7.5 & 116378.5 & 594424.3 & 8.4 \\
\hline 114266.4 & 594899.1 & 7.6 & 116706.2 & 594376.1 & 8.4 \\
\hline 114476.3 & 594871.3 & 7.6 & 116532.7 & 594408.6 & 8.4 \\
\hline 114355.9 & 594888.1 & 7.8 & 116408.1 & 594419.9 & 8.4 \\
\hline 114554.6 & 594853.4 & 7.9 & 116691.1 & 594379.9 & 8.5 \\
\hline 114373.9 & 594883.9 & 7.9 & 115844.3 & 594568.7 & 8.5 \\
\hline 114392.2 & 594867.1 & 7.9 & 116107.9 & 594501.9 & 8.6 \\
\hline 114343.1 & 594876.0 & 7.9 & 115872.8 & 594565.1 & 8.6 \\
\hline 114389.5 & 594882.8 & 8.0 & 116726.5 & 594369.1 & 8.6 \\
\hline 114335.9 & 594891.8 & 8.0 & 116082.9 & 594507.8 & 8.6 \\
\hline 114492.6 & 594848.9 & 8.1 & 115973.7 & 594534.8 & 8.7 \\
\hline 114239.7 & 594899.0 & 8.1 & 116715.7 & 594370.6 & 8.7 \\
\hline 114444.9 & 594874.9 & 8.1 & 115624.8 & 594629.8 & 8.7 \\
\hline 114368.1 & 594871.1 & 8.2 & 115900.5 & 594557.8 & 8.7 \\
\hline 114491.6 & 594867.6 & 8.3 & 116659.4 & 594375.8 & 8.7 \\
\hline 114316.2 & 594897.1 & 8.3 & 116691.2 & 594370.7 & 8.8 \\
\hline 114414.8 & 594877.0 & 8.4 & 116425.3 & 594425.0 & 8.8 \\
\hline 114566.1 & 594838.4 & 8.4 & 115537.1 & 594649.1 & 8.8 \\
\hline 114441.8 & 594857.3 & 8.4 & 115650.7 & 594618.0 & 8.8 \\
\hline 114317.4 & 594878.9 & 8.5 & 115594.4 & 594637.1 & 8.8 \\
\hline 114517.8 & 594845.7 & 8.5 & 115799.1 & 594572.4 & 8.8 \\
\hline 114467.7 & 594852.4 & 8.6 & 116129.3 & 594494.3 & 8.8 \\
\hline 114292.9 & 594898.0 & 8.7 & 115468.0 & 594662.9 & 8.8 \\
\hline 114417.1 & 594863.1 & 8.7 & 116796.9 & 594362.8 & 8.8 \\
\hline 114246.1 & 594881.8 & 8.7 & 115716.5 & 594603.2 & 8.8 \\
\hline 114292.2 & 594881.6 & 8.8 & 116203.4 & 594471.8 & 8.9 \\
\hline 114541.5 & 594840.0 & 8.9 & 116765.4 & 594365.7 & 8.9 \\
\hline 114246.2 & 594880.1 & 9.0 & 116749.0 & 594364.9 & 8.9 \\
\hline 114246.9 & 594880.1 & 9.1 & 116689.6 & 594380.3 & 8.9 \\
\hline 114246.3 & 594881.8 & 9.1 & 116254.8 & 594458.9 & 8.9 \\
\hline 114246.1 & 594881.3 & 9.1 & 115933.9 & 594542.3 & 9.0 \\
\hline 114245.7 & 594881.0 & 9.3 & 115914.1 & 594553.0 & 9.0 \\
\hline 114265.1 & 594883.1 & 9.3 & 116503.8 & 594410.9 & 9.1 \\
\hline 114246.2 & 594881.4 & 9.4 & 115862.9 & 594567.6 & 9.1 \\
\hline 114235.9 & 594882.3 & 9.4 & 116014.0 & 594526.8 & 9.1 \\
\hline 116060.3 & 594514.8 & 7.6 & 115955.1 & 594537.3 & 9.1 \\
\hline 116335.2 & 594436.1 & 7.6 & 116447.6 & 594421.4 & 9.2 \\
\hline 116283.2 & 594449.0 & 7.7 & 116558.6 & 594403.4 & 9.3 \\
\hline 115493.0 & 594661.6 & 7.7 & 116630.3 & 594378.2 & 9.3 \\
\hline 116771.2 & 594364.8 & 7.7 & 116225.4 & 594469.1 & 9.4 \\
\hline 116310.0 & 594440.8 & 7.9 & 116181.8 & 594479.4 & 9.4 \\
\hline 116741.0 & 594365.9 & 8.0 & 115991.4 & 594531.0 & 9.5 \\
\hline 115741.5 & 594594.2 & 8.1 & 116605.5 & 594387.8 & 9.6 \\
\hline 116787.9 & 594363.1 & 8.1 & 116475.4 & 594415.3 & 9.6 \\
\hline 115695.7 & 594605.9 & 8.2 & 115673.9 & 594607.1 & 9.6 \\
\hline 115821.8 & 594570.4 & 8.2 & 116153.7 & 594486.6 & 9.6 \\
\hline \multirow[t]{2}{*}{116037.5} & 594519.4 & 8.3 & 115564.6 & 594643.1 & 9.7 \\
\hline & & & 116582.5 & 594397.6 & 10.0 \\
\hline
\end{tabular}


Table B.10. External Radiation Measurements on the Columbia River Near the Vernita Bridge

\begin{tabular}{|c|c|c|c|c|c|}
\hline Northing $(\mathrm{m})^{(\mathrm{a})}$ & Easting (m) & Average $\mu R / h$ & Northing (m) ${ }^{(\mathbf{a})}$ & Easting (m) ${ }^{(a)}$ & Average $\mu \mathrm{R} / \mathrm{h}$ \\
\hline 144888.8 & 557186.7 & 3.4 & 145039.5 & 557977.6 & 3.2 \\
\hline 144888.6 & 557155.4 & 3.2 & 145062.6 & 557976.4 & 3.9 \\
\hline 144888.8 & 557130.3 & 4.1 & 145092.0 & 557969.7 & 3.4 \\
\hline 144891.5 & 557107.8 & 3.6 & 145101.6 & 557963.3 & 3.3 \\
\hline 144899.0 & 557095.9 & 2.9 & 145093.6 & 557942.6 & 3.0 \\
\hline 144901.4 & 557096.1 & 3.4 & 145089.1 & 557919.9 & 3.6 \\
\hline 144898.7 & 557106.4 & 3.7 & 145087.4 & 557898.1 & 3.2 \\
\hline 144896.9 & 557123.4 & 4.1 & 145084.3 & 557874.2 & 3.8 \\
\hline 144895.1 & 557141.9 & 4.5 & 145081.8 & 557852.7 & 3.4 \\
\hline 144894.6 & 557160.8 & 4.3 & 145081.3 & 557827.8 & 3.8 \\
\hline 144891.8 & 557179.5 & 4.3 & 145078.0 & 557805.5 & 3.5 \\
\hline 144888.0 & 557197.7 & 4.7 & 145071.5 & 557786.3 & 3.6 \\
\hline 144888.3 & 557216.3 & 3.8 & 145063.4 & 557766.9 & 3.3 \\
\hline 144892.3 & 557234.6 & 4.3 & 145055.3 & 557745.9 & 3.5 \\
\hline 144893.8 & 557252.9 & 3.4 & 145043.9 & 557727.4 & 3.2 \\
\hline 144893.2 & 557273.9 & 3.8 & 145031.3 & 557710.8 & 4.1 \\
\hline 144895.2 & 557294.6 & 3.9 & 145020.8 & 557692.3 & 3.1 \\
\hline 144898.2 & 557315.3 & 4.3 & 145009.5 & 557672.9 & 3.0 \\
\hline 144902.8 & 557335.1 & 3.6 & 144995.5 & 557652.4 & 2.9 \\
\hline 144902.0 & 557356.4 & 4.2 & 144982.0 & 557630.9 & 3.7 \\
\hline 144899.7 & 557377.1 & 3.3 & 144973.8 & 557604.5 & 3.5 \\
\hline 144897.2 & 557397.3 & 4.4 & 144963.3 & 557578.6 & 3.7 \\
\hline 144898.5 & 557419.6 & 3.9 & 144951.5 & 557545.9 & 3.8 \\
\hline 144901.9 & 557440.4 & 3.5 & 144938.0 & 557517.8 & 3.8 \\
\hline 144904.5 & 557461.7 & 3.9 & 144913.7 & 557504.4 & 4.2 \\
\hline 144905.4 & 557483.3 & 4.1 & 144894.3 & 557503.1 & 3.6 \\
\hline 144907.0 & 557506.9 & 4.1 & 144891.8 & 557502.9 & 3.6 \\
\hline 144909.6 & 557529.0 & 4.1 & 144891.8 & 557502.8 & 4.1 \\
\hline 144913.0 & 557552.9 & 3.0 & 144891.8 & 557502.9 & 4.1 \\
\hline 144912.2 & 557576.8 & 3.4 & 144893.5 & 557502.9 & 4.1 \\
\hline 144905.4 & 557598.6 & 3.8 & 144901.4 & 557502.8 & 4.2 \\
\hline 144894.2 & 557616.2 & 3.8 & 144913.0 & 557500.9 & 3.7 \\
\hline 144901.0 & 557649.5 & 4.1 & 144926.3 & 557500.2 & 3.3 \\
\hline 144913.1 & 557664.6 & 4.3 & 144934.0 & 557496.3 & 4.2 \\
\hline 144919.1 & 557685.2 & 5.6 & 144931.4 & 557465.4 & 4.1 \\
\hline 144926.4 & 557706.3 & 4.6 & 144929.7 & 557427.8 & 3.4 \\
\hline 144936.7 & 557728.4 & 3.7 & 144926.8 & 557391.7 & 3.0 \\
\hline 144947.6 & 557750.7 & 3.7 & 144924.6 & 557354.8 & 3.4 \\
\hline 144958.3 & 557773.3 & 2.8 & 144923.7 & 557322.7 & 3.2 \\
\hline 144967.2 & 557797.6 & 3.3 & 144921.0 & 557285.6 & 3.4 \\
\hline 144975.9 & 557823.6 & 4.0 & 144914.6 & 557248.8 & 3.8 \\
\hline 144984.4 & 557849.1 & 4.5 & 144913.2 & 557208.9 & 3.4 \\
\hline 144994.2 & 557873.7 & 3.3 & 144918.9 & 557176.4 & 3.3 \\
\hline 145003.8 & 557900.4 & 3.4 & 144923.0 & 557143.1 & 4.0 \\
\hline 145015.8 & 557926.1 & 4.0 & 144925.1 & 557113.9 & 3.6 \\
\hline \multirow[t]{4}{*}{145027.6} & 557952.1 & 4.2 & 144923.0 & 557086.4 & 3.3 \\
\hline & & & 144905.8 & 557070.1 & 3.7 \\
\hline & & & 144888.0 & 557069.1 & 3.5 \\
\hline & & & 144882.6 & 557071.6 & 3.9 \\
\hline
\end{tabular}


Table B.11. External Radiation Measurements on the Shoreline Near the Vernita Bridge

\begin{tabular}{|c|c|c|}
\hline Northing (m) ${ }^{(a)}$ & Easting (m) ${ }^{(a)}$ & Average $\mu \mathbf{R} / \mathbf{h}$ \\
\hline 144873.6 & 557074.3 & 8.4 \\
\hline 144866.0 & 557097.8 & 7.7 \\
\hline 144865.1 & 557128.4 & 8.3 \\
\hline 144862.4 & 557160.4 & 7.9 \\
\hline 144859.4 & 557191.4 & 9.0 \\
\hline 144858.1 & 557220.8 & 8.1 \\
\hline 144857.6 & 557251.4 & 8.0 \\
\hline 144856.3 & 557283.5 & 9.8 \\
\hline 144858.6 & 557312.7 & 9.4 \\
\hline 144860.1 & 557341.6 & 9.0 \\
\hline 144864.4 & 557370.8 & 8.6 \\
\hline 144864.5 & 557402.3 & 10.2 \\
\hline 144864.0 & 557438.7 & 9.7 \\
\hline 144871.5 & 557472.8 & 9.6 \\
\hline 144880.1 & 557500.8 & 8.3 \\
\hline 144876.1 & 557517.1 & 7.9 \\
\hline 144860.7 & 557526.9 & 8.5 \\
\hline \multicolumn{3}{|c|}{$\begin{array}{l}\text { (a) NAD } 1983 \text { (Conus), U.S. State Plane 1983, WA Soutl } \\
\text { 4602, m, HAE. }\end{array}$} \\
\hline
\end{tabular}




\section{Appendix C}

\section{Results for Chemical Samples}


Table C.1. Metals in Water Samples ${ }^{(a)}$ from the 300 Area Near-Shore, Riverbank Springs, and the Columbia River at Vernita Bridge

\begin{tabular}{|c|c|c|c|c|c|c|c|c|c|c|c|c|c|c|c|c|c|}
\hline & Filtered & $\mathrm{Hg}$ & $\mathrm{Be}$ & Al & $\mathbf{C r}$ & Mn & $\mathbf{N i}$ & $\mathbf{C u}$ & $\mathbf{Z n}$ & As & $\mathrm{Se}$ & $\mathbf{A g}$ & Cd & Sb & $\mathbf{P b}$ & $\mathbf{B a}$ & $\mathrm{Tl}$ \\
\hline Near-Shore River Water & \multicolumn{17}{|c|}{ Concentrations in $\mu \mathrm{g} / \mathrm{L}^{(\mathrm{b})}$} \\
\hline Location 7-1 & Yes & NA & 0.01 & 1.43 & 1.52 & 4.23 & 0.276 & 0.582 & 2.15 & 1.73 & 1.57 & 0.00134 & 0.0224 & 0.226 & 0.027 & 50.3 & 0.0445 \\
\hline Location 9-1 & Yes & NA & 0.01 & 0.991 & 2.37 & 1.97 & 0.254 & 0.535 & 2.50 & 1.10 & 2.34 & 0.0012 & 0.0257 & 0.226 & 0.0282 & 59.4 & 0.0486 \\
\hline Location 11-1 & Yes & NA & 0.01 & 1.03 & 0.423 & 2.21 & 0.191 & 0.637 & 1.16 & 0.732 & 0.313 & 0.0012 & 0.0143 & 0.224 & 0.0261 & 30.9 & 0.0252 \\
\hline Vernita Bridge-1 & Yes & 0.001 & 0.01 & 2.49 & 0.0783 & 1.38 & 0.300 & 0.696 & 1.24 & 0.668 & 0.238 & 0.00534 & 0.0283 & 0.223 & 0.0267 & 28.0 & 0.0284 \\
\hline Vernita Bridge-2 & Yes & NA & 0.01 & 1.38 & 0.247 & 1.24 & 0.191 & 0.627 & 0.925 & 0.650 & 0.190 & 0.0012 & 0.0149 & 0.207 & 0.022 & 28.2 & 0.0230 \\
\hline \multicolumn{18}{|l|}{ Riverbank Spring Water } \\
\hline Spring 7 & Yes & 0.0016 & 0.01 & 4.64 & 1.98 & 2.19 & 0.329 & 0.606 & 3.05 & 1.17 & 2.20 & 0.00277 & 0.0517 & 0.392 & 0.0387 & 72.1 & 0.0380 \\
\hline Spring 9 & Yes & 0.001 & 0.01 & 59.2 & 3.13 & 0.243 & 0.272 & 0.532 & 3.57 & 1.14 & 3.35 & 0.0012 & 0.0415 & 0.211 & 0.037 & 77.5 & 0.0682 \\
\hline \multicolumn{18}{|l|}{ Near-Shore River Water } \\
\hline Location 7-1 & No & NA & 0.01 & 30.6 & 1.18 & 7.17 & 0.375 & 0.672 & 2.69 & 1.80 & 1.58 & 0.0012 & 0.0259 & 0.206 & 0.0789 & 50.9 & 0.0239 \\
\hline Location 9-1 & No & NA & 0.01 & 62.7 & 2.17 & 8.16 & 0.465 & 0.742 & 4.20 & 1.19 & 2.23 & 0.0012 & 0.0481 & 0.208 & 0.213 & 59.3 & 0.0216 \\
\hline Location 11-1 & No & NA & 0.01 & 123 & 0.328 & 13.1 & 0.526 & 0.900 & 4.09 & 0.793 & 0.373 & 0.00596 & 0.0416 & 0.224 & 0.330 & 32.6 & 0.0271 \\
\hline Vernita Bridge-1 & No & NA & 0.01 & 16.2 & 0.533 & 4.17 & 0.302 & 0.742 & 1.77 & 0.76 & 0.31 & 0.00272 & 0.0244 & 0.201 & 0.0947 & 28.4 & 0.0240 \\
\hline Vernita Bridge-2 & No & NA & 0.01 & 32.8 & 0.214 & 5.08 & 0.357 & 0.764 & 2.85 & 0.712 & 0.273 & 0.00458 & 0.0243 & 0.208 & 0.168 & 29.4 & 0.0255 \\
\hline \multicolumn{18}{|l|}{ Riverbank Spring Water } \\
\hline Spring 7 & No & NA & 0.01 & 88.4 & 2.08 & 4.63 & 0.494 & 0.879 & 5.92 & 1.32 & 2.42 & 0.0014 & 0.302 & 0.233 & 0.209 & 79.2 & 0.0221 \\
\hline Spring 9 & No & NA & 0.01 & 39.4 & 3.09 & 2.59 & 0.365 & 0.575 & 4.49 & 1.20 & 3.47 & 0.0012 & 0.0494 & 0.201 & 0.731 & 80.9 & 0.0272 \\
\hline \multirow{2}{*}{\begin{tabular}{|l} 
Surface Freshwater \\
Quality Criteria (Acute)
\end{tabular}} & Yes & NS & NS & NS & 16 (as Cr VI) & NS & 750 & 8.4 & 60 & 360 & NS & 0.94 & 1.6 & NS & 28 & NS & NS \\
\hline & No & 2.1 & $\mathrm{NS}$ & NS & 300 (as Cr III) & NS & NS & NS & NS & NS & 20 & NS & NS & $\mathrm{NS}$ & NS & NS & NS \\
\hline \multirow{2}{*}{\begin{tabular}{|l} 
Surface Freshwater \\
Quality Criteria (Chronic)
\end{tabular}} & Yes & NS & NS & NS & 10 (as Cr VI) & NS & 83 & 6 & 55 & 190 & NS & NS & 0.59 & NS & 1.1 & NS & $\mathrm{NS}$ \\
\hline & No & 0.012 & NS & NS & 96 (as Cr III) & NS & NS & NS & NS & NS & 5 & NS & NS & NS & NS & NS & NS \\
\hline \multicolumn{18}{|c|}{$\begin{array}{l}\text { (a) Samples collected August } 27,2001 \text {. } \\
\text { (b) Italicized numbers were below the detection limit. } \\
\text { Surface Freshwater Quality Criteria from WAC } 173-201 \mathrm{~A}-040 \text {. } \\
\text { For hardness dependent criteria, the minimum value of } 47 \mathrm{mg} \text { as } \mathrm{CaCO}_{3} / \mathrm{L} \text { for } 1992-2000 . \\
\text { Columbia River water samples collected near Vernita Bridge by the USGS were used (from Poston et al. 2001). } \\
\text { NA = Not analyzed. } \\
\text { NS = No standard. }\end{array}$} \\
\hline
\end{tabular}


Table C.2. Cross-River and Near-Shore Results for Selected Anions and Metals for Columbia River Water

\begin{tabular}{|c|c|c|c|c|c|c|}
\hline Nitrate Data $(\mathrm{mg} / \mathrm{L})$ & Station 1 & Station 2 & Station 3 & Station 5 & Station 7 & Station 10 \\
\hline Vernita Bridge & 0.11 & & 0.082 & & 0.093 & 0.2 \\
\hline 300 Area HRM 41.5 & 0.067 & & & & & \\
\hline 300 Area HRM 42.2 & 0.25 & & & & & \\
\hline 300 Area HRM 42.5 & 0.065 & & & & & \\
\hline 300 Area HRM 42.9 & 0.053 & & & & & \\
\hline 300 Area HRM 43.1 & 0.051 & 0.06 & 0.051 & 0.055 & 0.073 & 0.33 \\
\hline Chloride Data (mg/L) & Station 1 & Station 2 & Station 3 & Station 5 & Station 7 & Station 10 \\
\hline Vernita Bridge & 1.2 & & 1.1 & & 1.1 & 1.4 \\
\hline 300 Area HRM 41.5 & 1.1 & & & & & \\
\hline 300 Area HRM 42.2 & 1.6 & & & & & \\
\hline 300 Area HRM 42.5 & 1.1 & & & & & \\
\hline 300 Area HRM 42.9 & 1.0 & & & & & \\
\hline 300 Area HRM 43.1 & 1.0 & 1.1 & 1.0 & 1.1 & 1.2 & 2.9 \\
\hline Sulfate (mg/L) & Station 1 & Station 2 & Station 3 & Station 5 & Station 7 & Station 10 \\
\hline Vernita Bridge & 9.2 & & 9.0 & & 9.1 & 10.5 \\
\hline 300 Area HRM 41.5 & 8.6 & & & & & \\
\hline 300 Area HRM 42.2 & 9.9 & & & & & \\
\hline 300 Area HRM 42.5 & 8.7 & & & & & \\
\hline 300 Area HRM 42.9 & 1.1 & & & & & \\
\hline 300 Area HRM 43.1 & 8.5 & 8.6 & 8.4 & 8.3 & 8.9 & 16.2 \\
\hline Chromium Data $(\mu \mathrm{g} / \mathrm{L})$ & Station 1 & Station 2 & Station 3 & Station 5 & Station 7 & Station 10 \\
\hline Vernita Bridge & 0.59 & & 0.52 & & 0.55 & 0.68 \\
\hline 300 Area HRM 41.5 & 0.32 & & & & & \\
\hline 300 Area HRM 42.2 & 0.41 & & & & & \\
\hline 300 Area HRM 42.5 & 0.26 & & & & & \\
\hline 300 Area HRM 42.9 & 0.29 & & & & & \\
\hline 300 Area HRM 43.1 & 0.37 & 0.29 & 0.37 & 0.36 & 0.35 & 0.48 \\
\hline Selenium Data $(\mu \mathrm{g} / \mathrm{L})$ & Station 1 & Station 2 & Station 3 & Station 5 & Station 7 & Station 10 \\
\hline Vernita Bridge & 0.18 & & 0.21 & & 0.18 & 0.28 \\
\hline 300 Area HRM 41.5 & 0.18 & & & & & \\
\hline 300 Area HRM 42.2 & 0.26 & & & & & \\
\hline 300 Area HRM 42.5 & 0.19 & & & & & \\
\hline 300 Area HRM 42.9 & 0.21 & & & & & \\
\hline 300 Area HRM 43.1 & 0.18 & 0.22 & 0.17 & 0.16 & 0.18 & 0.78 \\
\hline
\end{tabular}


Table C.3. Levels of Volatile Organics and Anions in Water Samples from the 300 Area Riverbank Springs and Columbia River at Vernita Bridge

\begin{tabular}{|c|c|c|c|c|c|}
\hline Analyte & $\begin{array}{c}\text { Riverbank Spring } \\
\text { Location } 9\end{array}$ & $\begin{array}{c}\text { Riverbank Spring } \\
\text { Location } 7\end{array}$ & $\begin{array}{c}\text { River Water Vernita } \\
\text { Bridge } 1\end{array}$ & $\begin{array}{c}\text { River Water Vernita } \\
\text { Bridge } 2\end{array}$ & Detection Limit \\
\hline \multicolumn{6}{|c|}{ Volatile Organics $(\mu \mathrm{g} / \mathrm{L})$} \\
\hline 1,1,1-trichloroethane & 0.31 & 0.31 & 0.31 & 0.31 & 0.31 \\
\hline 1,1,2-trichloroethane & 0.27 & 0.27 & 0.27 & 0.27 & 0.27 \\
\hline 1,1-dichloroethane & 0.25 & 0.25 & 0.25 & 0.25 & 0.25 \\
\hline 1,2-dichloroethane & 0.27 & 0.27 & 0.27 & 0.27 & 0.27 \\
\hline 1,4-dichlorobenzene & 0.25 & 0.25 & 0.25 & 0.25 & 0.25 \\
\hline 1-butanol & 4.9 & 4.9 & 4.9 & 4.9 & 4.9 \\
\hline acetone & 0.3 & 0.3 & 0.3 & 0.3 & 0.3 \\
\hline benzene & 0.23 & 0.23 & 0.23 & 0.23 & 0.23 \\
\hline carbon disulfide & 0.29 & 0.29 & 0.29 & 0.29 & 0.29 \\
\hline carbon tetrachloride & 0.33 & 0.33 & 0.33 & 0.33 & 0.33 \\
\hline chloroform & 0.21 & 0.21 & 0.21 & 0.21 & 0.21 \\
\hline cis-dichloroethylene & 0.32 & 0.24 & 0.24 & 0.24 & 0.24 \\
\hline ethyl cyanide & 2.0 & 2.0 & 2.0 & 2.0 & 2.0 \\
\hline 4-methyl-2-pentanone & 0.42 & 0.42 & 0.42 & 0.42 & 0.42 \\
\hline 2-butanone & 0.39 & 0.39 & 0.39 & 0.39 & 0.39 \\
\hline methylene chloride & $0.66 \mathrm{JB}$ & $0.56 \mathrm{JB}$ & 0.24 & $0.58 \mathrm{JB}$ & 0.24 \\
\hline tetrachloroethylene & 0.36 & 0.36 & 0.36 & 0.36 & 0.36 \\
\hline tetrahydrofuran & 2.3 & 2.3 & 2.3 & 2.3 & 2.3 \\
\hline toluene & 0.23 & 0.23 & 0.23 & 0.23 & 0.23 \\
\hline trans-dichloroethylene & 0.23 & 0.23 & 0.23 & 0.23 & 0.23 \\
\hline trichloroethylene & 2.0 & 0.29 & 0.29 & 0.29 & 0.29 \\
\hline vinyl chloride & 0.32 & 0.32 & 0.32 & 0.32 & 0.32 \\
\hline xylenes (total) & 0.66 & 0.66 & 0.66 & 0.66 & 0.66 \\
\hline
\end{tabular}


Table C.3. (contd)

\begin{tabular}{|c|c|c|c|c|c|}
\hline Analyte & $\begin{array}{c}\text { Riverbank Spring } \\
\text { Location } 9\end{array}$ & $\begin{array}{c}\text { Riverbank Spring } \\
\text { Location } 7\end{array}$ & $\begin{array}{c}\text { River Water Vernita } \\
\text { Bridge } 1\end{array}$ & $\begin{array}{c}\text { River Water Vernita } \\
\text { Bridge } 2\end{array}$ & Detection Limit \\
\hline \multicolumn{6}{|l|}{ Anions (mg/L) } \\
\hline chloride & 17.2 & 11.4 & 1 & 1 & \\
\hline fluoride & 0.26 & 0.21 & 0.006 & 0.1 & \\
\hline nitrite & 0.002 & 0.002 & 0.002 & 0.002 & \\
\hline nitrate & 4.9 & 3.2 & 0.05 & 0.054 & \\
\hline sulfate & 50 & 35.4 & 8.8 & 8.9 & \\
\hline
\end{tabular}


Table C.4. 300 Area Near-Shore Study of Metals in Riverbank Spring Sediment

\begin{tabular}{|c|c|c|c|c|c|c|c|c|c|c|c|c|c|c|}
\hline \multirow[b]{2}{*}{ Location } & \multirow{2}{*}{$\begin{array}{c}\text { Collection } \\
\text { Date }\end{array}$} & \multicolumn{13}{|c|}{ Concentrations in $\mu \mathrm{g} / \mathrm{g}$ dry wt } \\
\hline & & Hg & $\mathbf{B e}$ & $\mathbf{C r}$ & $\mathbf{N i}$ & $\mathbf{C u}$ & Zn & As & Se & Ag & Cd & Sb & Tl & $\mathbf{P b}$ \\
\hline 7 & $08 / 27 / 01$ & 0.000896 & 1.42 & 77.9 & 19.5 & 15.7 & 144 & 6.60 & 0.301 & 0.236 & 0.363 & 0.717 & 0.513 & 18.5 \\
\hline 9 & $08 / 27 / 01$ & 0.0144 & 1.26 & 55.0 & 18.4 & 21.3 & 215 & 7.84 & 0.504 & 0.233 & 0.867 & 0.564 & 0.589 & 22.7 \\
\hline 11 & $08 / 27 / 01$ & 0.000896 & 1.24 & 34.1 & 12.0 & 11.4 & 128 & 3.35 & 0.031 & 0.206 & 0.343 & 0.536 & 0.423 & 15.8 \\
\hline 14 & $08 / 27 / 01$ & 0.000896 & 1.34 & 43.2 & 16.3 & 16.8 & 154 & 5.89 & 0.347 & 0.224 & 0.341 & 0.498 & 0.435 & 16.6 \\
\hline \multicolumn{15}{|c|}{ Comparative Sediment Criteria } \\
\hline \multicolumn{2}{|c|}{ Ontario Lowest Effect Level } & 0.2 & NS & 26 & 16 & 16 & 120 & 6 & NS & 0.5 & 0.596 & NS & NS & 31 \\
\hline \multicolumn{2}{|c|}{ Environ. Canada Threshold Effect Level } & 0.174 & NS & 37.3 & 18 & 35.7 & 123.1 & 5.9 & NS & NS & 0.6 & NS & NS & 35 \\
\hline \multicolumn{2}{|c|}{ Ontario Sever Effect Level } & 2 & NS & 110 & 75 & 110 & 820 & 33 & $\mathrm{NS}$ & NS & 10 & NS & NS & 250 \\
\hline \multicolumn{2}{|c|}{ Environ. Canada Probable Effect Level } & 0.486 & NS & 90 & 35.9 & 197 & 314.8 & 17 & NS & NS & 3.53 & NS & NS & 91.3 \\
\hline
\end{tabular}


Table C.5. Non-Radiological Biological Sample Results ( $\mu$ g/g dry wt.)

\begin{tabular}{|c|c|c|c|c|c|c|c|c|c|c|c|c|c|c|c|c|c|c|c|}
\hline $\begin{array}{c}\text { Location } \\
\text { (river } \\
\text { depth, m) }\end{array}$ & Species & Tissue & Date & Hg & $\mathrm{Be}$ & Al & $\mathrm{Cr}$ & Mn & $\mathbf{N i}$ & $\mathbf{C u}$ & $\mathbf{Z n}$ & As & Se & Ag & Cd & Sb & $\mathbf{P b}$ & Th & $\mathbf{U}$ \\
\hline 7 (spring) & Corbicula & Soft Tissue & $8 / 27 / 2001$ & NA & 0.0451 & 209 & 3.65 & 18.6 & 1.13 & 29.3 & 116 & 8.90 & 0.569 & 0.0993 & 2.81 & 0.0148 & 0.223 & 1.02 & 2.07 \\
\hline $7(0.25)$ & Corbicula & Soft Tissue & $8 / 27 / 2001$ & $\mathrm{NA}$ & 0.208 & 400 & 4.02 & 39.8 & 1.84 & 26.0 & 164 & 11.4 & 0.569 & 0.143 & 2.20 & \begin{tabular}{|l|}
0.0396 \\
\end{tabular} & 1.68 & 3.09 & 4.31 \\
\hline $7(0.5)$ & Corbicula & Soft Tissue & $8 / 27 / 2001$ & NA & \begin{tabular}{|l|}
0.0633 \\
\end{tabular} & 409 & 9.20 & 37.7 & 1.67 & 65.7 & 117 & 17.9 & 0.791 & 0.134 & 2.27 & \begin{tabular}{|l|}
0.0379 \\
\end{tabular} & 0.761 & 1.51 & 1.88 \\
\hline $7(1.0)$ & Corbicula & Soft Tissue & \begin{tabular}{|l|}
$8 / 27 / 2001$ \\
\end{tabular} & NA & 0.0451 & 201 & 1.98 & 17.0 & 0.708 & 22.8 & 85.1 & 11.0 & 1.62 & 0.0569 & 0.916 & 0.0140 & 0.499 & 0.612 & 0.542 \\
\hline $7(1.5)$ & Corbicula & Soft Tissue & $8 / 27 / 2001$ & $\mathrm{NA}$ & 0.0509 & 303 & 2.96 & 41.5 & 1.46 & 27.2 & 181 & 11.5 & 0.569 & 0.0838 & 1.82 & \begin{tabular}{|l|}
0.0231 \\
\end{tabular} & 0.923 & 1.30 & 0.803 \\
\hline DR $7(0.25)$ & Corbicula & Soft Tissue & $8 / 27 / 2001$ & NA & \begin{tabular}{|l|}
0.0451 \\
\end{tabular} & 326 & 3.60 & 30.4 & 1.36 & 28.7 & 154 & 16.4 & 0.569 & 0.0787 & 1.92 & \begin{tabular}{|l|}
0.0278 \\
\end{tabular} & 0.847 & 1.23 & 2.03 \\
\hline DR $7(0.5)$ & Corbicula & Soft Tissue & $8 / 27 / 2001$ & NA & \begin{tabular}{|l|}
0.0786 \\
\end{tabular} & 374 & 2.56 & 44.2 & 1.68 & 24.0 & 135 & 11.6 & 3.10 & 0.0862 & 1.56 & 0.0313 & 1.23 & 1.81 & 1.82 \\
\hline DR $7(1.0)$ & Corbicula & Soft Tissue & $8 / 27 / 2001$ & NA & \begin{tabular}{|l|}
0.0451 \\
\end{tabular} & 90.8 & 4.67 & 20.8 & 0.815 & 44.8 & 97.1 & 12.6 & 1.13 & 0.0778 & 1.70 & \begin{tabular}{|l|}
0.0129 \\
\end{tabular} & 0.431 & 1.11 & 0.724 \\
\hline DR $7(1.5)$ & Corbicula & Soft Tissue & $8 / 27 / 2001$ & NA & 0.0451 & 83.4 & 1.60 & 29.0 & 0.919 & 31.2 & 131 & 13.3 & 2.54 & 0.0708 & 1.64 & 0.0195 & 0.551 & 1.40 & 0.461 \\
\hline $7 / 9$ & Corbicula & Soft Tissue & $8 / 27 / 2001$ & 0.0737 & \begin{tabular}{|l|}
0.0615 \\
\end{tabular} & 247 & 2.90 & 39.7 & 1.80 & 40.7 & 133 & 14.3 & 4.01 & 0.0884 & 2.59 & 0.0268 & 0.971 & 1.66 & 0.630 \\
\hline 9 (spring) & Corbicula & Soft Tissue & $8 / 27 / 2001$ & NA & \begin{tabular}{|l|}
0.0451 \\
\end{tabular} & 162 & 3.24 & 18.8 & 0.742 & 37.1 & 90.8 & 13.0 & 2.17 & 0.0946 & 2.00 & 0.0149 & 0.306 & 1.01 & 3.34 \\
\hline $9(0.25)$ & Corbicula & Soft Tissue & $8 / 27 / 2001$ & $\mathrm{NA}$ & 0.0899 & 142 & 11.3 & 22.7 & 1.39 & 62.3 & 136 & 18.5 & 0.569 & 0.151 & 3.86 & \begin{tabular}{|l|}
0.0256 \\
\end{tabular} & 0.791 & 2.07 & 6.77 \\
\hline $9(0.5)$ & Corbicula & Soft Tissue & $8 / 27 / 2001$ & NA & 0.0451 & 90.8 & 5.57 & 23.8 & 0.721 & 49.8 & 109 & 15.4 & 3.00 & 0.0753 & 1.78 & 0.0137 & 0.449 & 1.17 & 2.10 \\
\hline $9(1.0)$ & Corbicula & Soft Tissue & $8 / 27 / 2001$ & NA & 0.0451 & 257 & 1.57 & 33.2 & 1.02 & 24.7 & 120 & 11.3 & 2.18 & 0.0555 & 1.49 & 0.0195 & 0.643 & 1.01 & 0.282 \\
\hline $9(1.5)$ & Corbicula & Soft Tissue & $8 / 27 / 2001$ & $\mathrm{NA}$ & \begin{tabular}{|l|}
0.0497 \\
\end{tabular} & 319 & 2.60 & 46.2 & 1.39 & 26.8 & 153 & 11.7 & 0.903 & 0.0665 & 2.04 & \begin{tabular}{|l|}
0.0288 \\
\end{tabular} & 1.01 & 1.57 & 0.945 \\
\hline DR $9(0.25)$ & Corbicula & Soft Tissue & $8 / 27 / 2001$ & NA & 0.0451 & 52.1 & 2.84 & 8.9 & 0.421 & 20.7 & 70.0 & 10.0 & 0.569 & 0.0306 & 0.933 & 0.00891 & 0.310 & 0.690 & 1.85 \\
\hline DR $9(0.5)$ & Corbicula & Soft Tissue & $8 / 27 / 2001$ & NA & 0.0451 & 40.5 & 9.90 & 17.3 & \begin{tabular}{|l|}
0.974 \\
\end{tabular} & 59.4 & 113 & 19.1 & 0.569 & 0.0751 & 3.20 & \begin{tabular}{|l|}
0.0163 \\
\end{tabular} & 0.543 & 1.50 & 6.40 \\
\hline DR $9(1.0)$ & Corbicula & Soft Tissue & $8 / 27 / 2001$ & NA & \begin{tabular}{|l|}
0.0640 \\
\end{tabular} & 131 & 2.84 & 36.4 & 1.24 & 24.9 & 130 & 11.1 & 0.595 & 0.0608 & 2.12 & 0.0199 & 0.799 & 1.90 & 3.05 \\
\hline DR 9 (1.5) & Corbicula & Soft Tissue & $8 / 27 / 2001$ & NA & \begin{tabular}{|l|}
0.0522 \\
\end{tabular} & 137 & 1.90 & 34.8 & 1.14 & 21.4 & 147 & 10.2 & 0.569 & 0.0508 & 1.61 & 0.0176 & 0.847 & 2.23 & 0.941 \\
\hline \begin{tabular}{|l|}
$9 / 11$ \\
\end{tabular} & Corbicula & Soft Tissue & $8 / 27 / 2001$ & 0.0554 & \begin{tabular}{|l|}
0.0513 \\
\end{tabular} & 404 & 1.76 & 35.4 & 1.49 & 22.9 & 146 & 10.2 & 2.28 & 0.0557 & 2.30 & 0.0237 & 0.892 & 1.55 & 0.818 \\
\hline $11(0.25)$ & Corbicula & Soft Tissue & $8 / 27 / 2001$ & NA & 0.0451 & 88.5 & 2.37 & 15.2 & 0.714 & 21.2 & 90.3 & 9.1 & 1.66 & 0.0363 & 1.47 & 0.00870 & 0.333 & 0.618 & 1.84 \\
\hline $11(0.5)$ & Corbicula & Soft Tissue & $8 / 27 / 2001$ & 0.0497 & 0.0427 & 140 & 1.62 & 40.5 & 1.06 & 24.3 & 122 & 11.3 & 1.73 & 0.0671 & 1.50 & \begin{tabular}{|l|}
0.0177 \\
\end{tabular} & 0.729 & 1.40 & 1.95 \\
\hline $11(1.0)$ & Corbicula & Soft Tissue & $8 / 27 / 2001$ & 0.0180 & 0.0451 & 120 & 1.77 & 18.7 & 0.678 & 17.5 & 99.3 & 12.2 & 0.569 & 0.027 & 1.42 & 0.0057 & 0.478 & 0.880 & 0.473 \\
\hline
\end{tabular}




\begin{tabular}{|c|c|c|c|c|c|c|c|c|c|c|c|c|c|c|c|c|c|c|c|}
\hline $\begin{array}{c}\text { Location } \\
\text { (river } \\
\text { depth, m) }\end{array}$ & Species & Tissue & Date & $\mathrm{Hg}$ & Be & Al & $\mathrm{Cr}$ & Mn & $\mathrm{Ni}$ & $\mathbf{C u}$ & $\mathbf{Z n}$ & As & Se & Ag & Cd & Sb & $\mathbf{P b}$ & Th & $\mathbf{U}$ \\
\hline $11(1.5)$ & Corbicula & Soft Tissue & \begin{tabular}{|l|}
$8 / 27 / 2001$ \\
\end{tabular} & 0.0384 & 0.0451 & 75.1 & 1.48 & 19.9 & 0.695 & 26.9 & 96.9 & 10.6 & 1.28 & 0.0550 & 1.31 & 0.0134 & \begin{tabular}{|l|l|} 
& 0.454 \\
\end{tabular} & \begin{tabular}{|l|l|}
0.924 \\
\end{tabular} & 0.944 \\
\hline & & & & & & & & & & & & & & & & & & & \\
\hline $14(0.25)$ & Corbicula & Soft Tissue & $8 / 27 / 2001$ & 0.0499 & 0.0501 & 267 & 2.44 & 23.2 & 1.01 & 33.7 & 106 & 11.1 & 0.569 & 0.0719 & 2.13 & 0.0145 & 0.640 & 1.35 & 0.217 \\
\hline $14(0.5)$ & Corbicula & Soft Tissue & $8 / 27 / 2001$ & 0.0163 & 0.0451 & 154 & 1.51 & 27.9 & 0.999 & 23.2 & 101 & 13.4 & 0.569 & 0.0269 & 1.92 & 0.00714 & \begin{tabular}{|l|}
0.822 \\
\end{tabular} & 0.940 & 0.112 \\
\hline $14(1.0)$ & Corbicula & Soft Tissue & \begin{tabular}{|l|}
$8 / 27 / 2001$ \\
\end{tabular} & 0.0493 & 0.0451 & 105 & 3.44 & 25.1 & 0.835 & 48.3 & 95.8 & 16.2 & 1.51 & 0.0946 & 2.47 & 0.0133 & \begin{tabular}{|l|l|}
0.678 \\
\end{tabular} & 1.11 & 0.208 \\
\hline $14(1.5)$ & Corbicula & Soft Tissue & $8 / 27 / 2001$ & 0.0261 & 0.0451 & 97.3 & 0.543 & 5.45 & 0.316 & 13.7 & 70.2 & \begin{tabular}{|l|}
7.11 \\
\end{tabular} & 0.569 & 0.027 & \begin{tabular}{|l|l|}
0.636 \\
\end{tabular} & 0.0057 & \begin{tabular}{|l|l|}
0.316 \\
\end{tabular} & \begin{tabular}{|l|l|}
0.466 \\
\end{tabular} & 0.0516 \\
\hline $\begin{array}{l}\text { Vernita } \\
\text { (spring) }\end{array}$ & Corbicula & Soft Tissue & \begin{tabular}{|l|}
$9 / 11 / 2001$ \\
\end{tabular} & 0.0190 & 0.0451 & 32.3 & 1.35 & 17.5 & 0.520 & 36.2 & 123 & \begin{tabular}{|l|}
10.4 \\
\end{tabular} & 0.569 & 0.0596 & 2.63 & 0.0127 & 0.273 & 0 & 0.198 \\
\hline $\begin{array}{l}\text { Vernita } \\
(0.25)\end{array}$ & Corbicula & Soft Tissue & 9/11/2001 & 0.0471 & 0.0794 & 475 & 1.89 & 39.0 & 1.54 & 39.1 & 110 & 13.1 & 0.569 & 0.110 & 2.76 & 0.0258 & 1.68 & 1.49 & 0.229 \\
\hline Vernita $(0.5)$ & Corbicula & Soft Tissue & 9/11/2001 & 0.0528 & 0.0482 & 117 & 2.99 & 30.1 & 0.845 & 55.6 & 91.9 & 13.1 & 0.569 & 0.102 & 2.72 & 0.0169 & 0.951 & 1.73 & 0.191 \\
\hline Vernita (1.0) & Corbicula & Soft Tissue & 9/11/2001 & 0.0328 & 0.121 & 267 & 1.29 & 43.8 & 1.29 & 27.4 & 150 & 8.85 & 0.569 & 0.112 & 3.44 & 0.0359 & 1.39 & 4.11 & 0.420 \\
\hline Vernita (1.5) & Corbicula & Soft Tissue & 9/11/2001 & 0.0284 & 0.0451 & 114 & 1.14 & 23.5 & 0.145 & 37.6 & 111 & 13.4 & 0.569 & 0.0708 & 1.99 & 0.0160 & \begin{tabular}{|l|l|} 
& 0.696 \\
\end{tabular} & 0 & 0.169 \\
\hline 7 (spring) & Corbicula & Shell & \begin{tabular}{|l|}
$8 / 27 / 2001$ \\
\end{tabular} & 0.000817 & 0.04 & 38.7 & 0.122 & 16.4 & 9.52 & 5.80 & 3.41 & 0.1 & 0.2 & 0.0157 & \begin{tabular}{|l|}
0.0913 \\
\end{tabular} & 0.0164 & 0.125 & 0.0321 & 0.575 \\
\hline $7(0.25)$ & Corbicula & Shell & \begin{tabular}{|l|}
$8 / 27 / 2001$ \\
\end{tabular} & 0.000817 & 0.04 & 21.5 & 0.1 & 11.2 & 9.43 & 3.79 & 1.45 & 0.1 & 0.275 & 0.01 & 0.01 & 0.01 & 0.0845 & 0.0213 & 0.455 \\
\hline $7(0.5)$ & Corbicula & Shell & \begin{tabular}{|l|}
$8 / 27 / 2001$ \\
\end{tabular} & 0.000817 & 0.04 & 42.5 & 0.159 & 80.9 & 9.39 & 4.24 & 2.55 & 0.829 & 0.2 & 0.0156 & 0.01 & 0.0249 & 0.173 & 0.0812 & 0.914 \\
\hline $7(1.0)$ & Corbicula & Shell & \begin{tabular}{|l|}
$8 / 27 / 2001$ \\
\end{tabular} & 0.000817 & 0.04 & 54.9 & 0.348 & $258^{(\mathrm{b})}$ & 8.72 & 6.76 & 7.58 & 2.25 & 0.210 & 0.0165 & \begin{tabular}{|l|}
0.0409 \\
\end{tabular} & 0.0258 & \begin{tabular}{|l|}
0.328 \\
\end{tabular} & 0.0625 & 1.30 \\
\hline $7(1.5)$ & Corbicula & Shell & $8 / 27 / 2001$ & 0.000817 & 0.04 & 18.0 & 0.153 & 40.2 & 9.55 & 3.79 & 5.02 & 0.194 & 0.2 & 0.01 & \begin{tabular}{|l|l|}
0.0140 \\
\end{tabular} & 0.0153 & 0.0940 & \begin{tabular}{|l|l}
0.0294 \\
\end{tabular} & 1.29 \\
\hline & & & & & & & & & & & & & & & & & & & \\
\hline$\frac{\text { DR 7 (0.25) }}{\text { DR 7 (0.5) }}$ & \begin{tabular}{|l|} 
Corbicula \\
Corbicula
\end{tabular} & \begin{tabular}{|l|} 
Shell \\
Shell
\end{tabular} & \begin{tabular}{|l|}
$8 / 27 / 2001$ \\
$8 / 27 / 2001$ \\
\end{tabular} & \begin{tabular}{|c|}
0.000817 \\
0.000817
\end{tabular} & \begin{tabular}{|l|}
0.04 \\
0.04
\end{tabular} & $\begin{array}{l}63.8 \\
14.9\end{array}$ & $\begin{array}{c}0.310 \\
0.1\end{array}$ & $\begin{array}{l}29.9 \\
190\end{array}$ & \begin{tabular}{l|}
9.22 \\
10.3
\end{tabular} & $\begin{array}{l}9.60 \\
296\end{array}$ & $\begin{array}{l}6.90 \\
2.09\end{array}$ & $\frac{0.1}{0.1}$ & \begin{tabular}{|c|}
0.512 \\
0.2
\end{tabular} & $\begin{array}{l}0.0135 \\
0.01\end{array}$ & \begin{tabular}{|l|}
0.0495 \\
0.0121
\end{tabular} & $\frac{0.0188}{0.01}$ & \begin{tabular}{|l|}
0.186 \\
0.0801 \\
\end{tabular} & \begin{tabular}{|l|}
0.0467 \\
0.0191
\end{tabular} & $\begin{array}{c}2.32 \\
0.377\end{array}$ \\
\hline DR 7 (0.5) & Corbicula & Shell & \begin{tabular}{|l|}
$8 / 27 / 2001$ \\
\end{tabular} & 0.000817 & 0.04 & 38.2 & 0.158 & 34.0 & 10.2 & 5.95 & 5.74 & 0.1 & 0.2 & 0.01 & \begin{tabular}{|l|}
0.0296 \\
\end{tabular} & 0.01 & 0.151 & 0.0350 & 0.791 \\
\hline DR 7 (1.0) & Corbicula & Shell & $8 / 27 / 2001$ & 0.000817 & 0.04 & 40.0 & 0.107 & 31.5 & 10.2 & 3.66 & 4.68 & 0.1 & 0.2 & 0.0121 & \begin{tabular}{|l|l|}
0.0274 \\
\end{tabular} & 0.0111 & 0.127 & 0.0237 & 1.32 \\
\hline DR $7(1.5)$ & Corbicula & Shell & $8 / 27 / 2001$ & 0.000817 & 0.04 & 25.2 & 0.113 & 40.9 & 9.70 & 6.96 & 4.79 & 0.1 & 0.2 & 0.0111 & \begin{tabular}{|l|l|}
0.0529 \\
\end{tabular} & 0.01 & 0.0926 & 0.0115 & 0.266 \\
\hline $7 / 9$ & Corbicula & Shell & $8 / 27 / 2001$ & \begin{tabular}{|l|l|}
0.000817 \\
\end{tabular} & 0.04 & 88.6 & 0.247 & 61.5 & 9.09 & 8.16 & 6.10 & 0.173 & 0.368 & 0.0317 & \begin{tabular}{|l|l|}
0.102 \\
\end{tabular} & 0.0265 & \begin{tabular}{|l|l|} 
& 0.258 \\
\end{tabular} & |0.0577 & 0.181 \\
\hline 9 (spring) & Corbicula & Shell & \begin{tabular}{|l|}
$8 / 27 / 2001$ \\
\end{tabular} & 0.000817 & \begin{tabular}{|l|}
0.04 \\
\end{tabular} & 51.5 & 0.292 & 24.1 & \begin{tabular}{|l|}
9.46 \\
\end{tabular} & 7.35 & 5.11 & 0.1 & 0.216 & 0.0133 & \begin{tabular}{|l|}
0.0527 \\
\end{tabular} & 0.0135 & \begin{tabular}{|l|}
0.150 \\
\end{tabular} & \begin{tabular}{|l|l|}
0.0451 \\
\end{tabular} & 4.40 \\
\hline $9(0.25)$ & Corbicula & Shell & \begin{tabular}{|l|}
$8 / 27 / 2001$ \\
\end{tabular} & 0.000817 & 0.04 & 86.5 & 0.517 & 14.9 & \begin{tabular}{l|l}
9.46 \\
\end{tabular} & 8.07 & 6.57 & 0.1 & 1.16 & 0.01 & \begin{tabular}{|l|}
0.0631 \\
\end{tabular} & 0.0170 & \begin{tabular}{|l|}
0.186 \\
\end{tabular} & 0.0295 & 11.2 \\
\hline
\end{tabular}




\begin{tabular}{|c|c|c|c|c|c|c|c|c|c|c|c|c|c|c|c|c|c|c|c|}
\hline $\begin{array}{c}\begin{array}{c}\text { Location } \\
\text { (river } \\
\text { depth, } m \text { ) }\end{array} \\
\end{array}$ & Species & Tissue & Date & $\mathbf{H g}$ & $\mathrm{Be}$ & Al & $\mathrm{Cr}$ & Mn & $\mathbf{N i}$ & $\mathbf{C u}$ & Zn & As & Se & Ag & $\mathrm{Cd}$ & Sb & $\mathbf{P b}$ & Th & $\mathbf{U}$ \\
\hline $9(0.5)$ & Corbicula & Shell & $8 / 27 / 2001$ & 0.000817 & 0.04 & 53.1 & 0.269 & 42.6 & 9.98 & 8.13 & 6.12 & 0.1 & 0.2 & 0.01 & 0.0617 & 0.0177 & 0.133 & \begin{tabular}{|l|l|}
0.0294 \\
\end{tabular} & 4.23 \\
\hline $9(1.0)$ & Corbicula & Shell & $8 / 27 / 2001$ & 0.000817 & 0.04 & 43.5 & 0.1 & 34.3 & 10.0 & 11.5 & \begin{tabular}{|l|l|}
5.44 \\
\end{tabular} & 0.1 & 0.2 & 0.01 & 0.0602 & 0.0114 & 0.112 & \begin{tabular}{|l|l|}
0.0172 \\
\end{tabular} & 0.219 \\
\hline $9(1.5)$ & Corbicula & Shell & $8 / 27 / 2001$ & 0.000817 & 0.04 & 28.1 & 0.1 & 15.0 & 7.85 & 7.56 & \begin{tabular}{|l|}
4.26 \\
\end{tabular} & 0.1 & 0.341 & 0.0246 & 0.0523 & 0.0161 & 0.0858 & \begin{tabular}{|l|l|}
0.0411 \\
\end{tabular} & 0.679 \\
\hline DR $9(0.25)$ & Corbicula & Shell & $8 / 27 / 2001$ & 0.000817 & 0.04 & 81.9 & $43.2^{(b)}$ & 58.7 & 47.9 & 12.6 & \begin{tabular}{|l|l|}
6.58 \\
\end{tabular} & 0.186 & 0.344 & 0.0265 & \begin{tabular}{|l|}
0.0659 \\
\end{tabular} & 0.0186 & 0.590 & \begin{tabular}{|l|l|}
0.0365 \\
\end{tabular} & 5.99 \\
\hline DR 9 (0.5) & Corbicula & Shell & $8 / 27 / 2001$ & 0.000817 & 0.04 & 69.3 & 0.353 & 70.7 & 9.72 & 9.81 & 6.50 & 0.137 & 0.441 & 0.0104 & 0.0993 & 0.0143 & 0.183 & \begin{tabular}{|l|l|}
0.0308 \\
\end{tabular} & 6.48 \\
\hline DR $9(1.0)$ & Corbicula & Shell & $8 / 27 / 2001$ & 0.000817 & 0.04 & 58.1 & 0.151 & 25.2 & 9.51 & 7.28 & \begin{tabular}{|l|l}
4.39 \\
\end{tabular} & 0.1 & 0.2 & 0.0134 & \begin{tabular}{|l|}
0.0434 \\
\end{tabular} & 0.0137 & 0.114 & \begin{tabular}{|l|}
0.0386 \\
\end{tabular} & 2.53 \\
\hline DR 9 (1.5) & Corbicula & Shell & $8 / 27 / 2001$ & 0.000817 & 0.04 & 65.8 & 0.406 & 58.8 & 9.39 & 9.50 & 10.3 & 0.147 & 0.418 & 0.01 & 0.120 & 0.0217 & 0.180 & \begin{tabular}{|l|l|}
0.0726 \\
\end{tabular} & 1.97 \\
\hline $9 / 11$ & Corbicula & Shell & $8 / 27 / 2001$ & 0.000817 & 0.04 & 21.8 & 0.299 & 7.22 & 5.70 & 2.20 & \begin{tabular}{|l|}
1.28 \\
\end{tabular} & 1.19 & 0.2 & 0.01 & \begin{tabular}{|l|}
0.0193 \\
\end{tabular} & 0.01 & 0.0345 & 0.01 & 0.0766 \\
\hline $11(0.25)$ & Corbicula & Shell & $8 / 27 / 2001$ & 0.000817 & 0.04 & 31.3 & 0.1 & 17.5 & 9.10 & 10.4 & \begin{tabular}{|l|l|}
4.66 \\
\end{tabular} & 0.1 & 0.423 & 0.0230 & 0.0863 & 0.0159 & 0.138 & \begin{tabular}{|l|}
0.0421 \\
\end{tabular} & 0.545 \\
\hline $11(0.5)$ & Corbicula & Shell & $8 / 27 / 2001$ & 0.000817 & 0.04 & 29.6 & 0.173 & 33.5 & 9.25 & 5.77 & 7.49 & 0.166 & 0.2 & 0.0245 & 0.120 & 0.01 & 0.118 & \begin{tabular}{|l|}
0.0208 \\
\end{tabular} & 0.543 \\
\hline $11(0.5)$ & Corbicula & Shell & $8 / 27 / 2001$ & 0.000817 & 0.04 & 24.5 & 0.278 & 30.2 & 9.58 & 4.96 & 9.96 & 0.121 & 0.2 & 0.0197 & 0.125 & 0.0149 & 0.110 & \begin{tabular}{|l|}
0.0227 \\
\end{tabular} & 0.484 \\
\hline $11(1.0)$ & Corbicula & Shell & $8 / 27 / 2001$ & 0.000817 & 0.04 & 52.5 & 0.264 & 44.7 & 8.95 & 7.21 & 6.89 & 0.102 & 0.2 & 0.0151 & 0.0893 & 0.01 & 0.177 & 0.0520 & 1.70 \\
\hline $11(1.5)$ & Corbicula & Shell & $8 / 27 / 2001$ & 0.000817 & 0.04 & 60.7 & 0.250 & 79.1 & 8.61 & 8.13 & 7.69 & 0.111 & 0.2 & 0.0368 & 0.0907 & 0.01 & 0.198 & \begin{tabular}{|l|}
0.0354 \\
\end{tabular} & 1.06 \\
\hline $14(0.25)$ & Corbicula & Shell & $8 / 27 / 2001$ & $\mathrm{NA}^{(\mathrm{a})}$ & 0.04 & 21.4 & 0.102 & 35.1 & 8.84 & 3.89 & \begin{tabular}{|l|l|}
2.87 \\
\end{tabular} & 0.1 & 0.2 & 0.01 & \begin{tabular}{|l|}
0.0728 \\
\end{tabular} & 0.01 & 0.121 & \begin{tabular}{|l|l|}
0.0232 \\
\end{tabular} & 0.0998 \\
\hline $14(0.5)$ & Corbicula & Shell & $8 / 27 / 2001$ & 0.000817 & 0.04 & 23.7 & 0.1 & 6.09 & 5.81 & 1.24 & 0.982 & 1.21 & 0.471 & 0.01 & 0.0145 & 0.01 & 0.0393 & 0.01 & 0.0219 \\
\hline $14(1.0)$ & Corbicula & Shell & $8 / 27 / 2001$ & 0.000817 & 0.04 & 54.5 & 0.111 & 15.9 & 9.21 & 5.32 & 3.58 & 0.1 & 0.2 & 0.01 & 0.0564 & 0.0101 & \begin{tabular}{|l|}
0.160 \\
\end{tabular} & \begin{tabular}{|l|}
0.0272 \\
\end{tabular} & 0.0830 \\
\hline $14(1.5)$ & Corbicula & Shell & $8 / 27 / 2001$ & 0.000817 & 0.04 & 62.3 & 0.170 & 20.2 & 9.48 & 5.70 & 5.38 & 0.310 & 0.2 & 0.0193 & 0.0836 & 0.0169 & 0.277 & \begin{tabular}{|l|l|}
0.0333 \\
\end{tabular} & 0.0319 \\
\hline $\begin{array}{l}\text { Vernita } \\
\text { (spring) }\end{array}$ & Corbicula & Shell & $9 / 11 / 2001$ & 0.000817 & 0.04 & 39.8 & 0.1 & 50.6 & 9.19 & 4.58 & 5.24 & 0.1 & 0.2 & 0.0101 & 0.0723 & 0.0130 & 0.138 & 0.217 & 0.0995 \\
\hline \begin{tabular}{|l|} 
Vernita \\
$(0.25)$ \\
\end{tabular} & Corbicula & Shell & $9 / 11 / 2001$ & 0.000817 & 0.04 & 51.7 & 0.1 & 111 & 8.95 & 6.41 & 7.40 & 0.180 & 0.2 & 0.0130 & 0.106 & 0.0242 & 0.296 & 0.0334 & 0.0717 \\
\hline Vernita $(0.5)$ & Corbicula & Shell & $9 / 11 / 2001$ & \begin{tabular}{|l|}
0.000817 \\
\end{tabular} & 0.04 & 80.1 & 0.243 & $1040^{(\mathrm{b})}$ & 9.85 & 6.99 & 23.7 & 1.45 & 0.2 & 0.0153 & 0.286 & 0.0393 & \begin{tabular}{|l|}
0.494 \\
\end{tabular} & \begin{tabular}{|l|}
0.138 \\
\end{tabular} & 0.105 \\
\hline Vernita (1.0) & Corbicula & Shell & $9 / 11 / 2001$ & 0.000817 & 0.04 & 64.2 & 0.118 & 77.9 & 9.70 & 6.07 & 5.36 & 0.1 & 0.2 & 0.0171 & 0.119 & 0.0153 & \begin{tabular}{|l|}
0.569 \\
\end{tabular} & \begin{tabular}{|l|}
0.0394 \\
\end{tabular} & 0.0734 \\
\hline Vernita (1.5) & Corbicula & Shell & $9 / 11 / 2001$ & 0.000817 & 0.04 & 12.5 & 0.1 & 19.5 & 10.4 & 3.23 & \begin{tabular}{|l|}
1.96 \\
\end{tabular} & 0.1 & 0.2 & 0.01 & 0.0367 & 0.01 & 0.0649 & 0.01 & 0.0232 \\
\hline $7-1$ & Crayfish & Hepatopancreas & $8 / 27 / 2001$ & 0.0036 & 0.0451 & 9.80 & 0.617 & 53.1 & 0.04 & 50.5 & 94.9 & 9.55 & 0.569 & 0.288 & 1.25 & 0.0975 & 0.0970 & 0 & 1.26 \\
\hline
\end{tabular}




\begin{tabular}{|c|c|c|c|c|c|c|c|c|c|c|c|c|c|c|c|c|c|c|c|}
\hline $\begin{array}{c}\text { Location } \\
\text { (river } \\
\text { depth, } m \text { ) }\end{array}$ & Species & Tissue & Date & $\mathrm{Hg}$ & $\mathrm{Be}$ & Al & $\mathrm{Cr}$ & Mn & $\mathrm{Ni}$ & $\mathrm{Cu}$ & Zn & As & Se & Ag & Cd & Sb & $\mathbf{P b}$ & Th & $\mathbf{U}$ \\
\hline $7-2$ & Crayfish & Hepatopancreas & $8 / 27 / 2001$ & 0.0156 & 0.0451 & 13.1 & 0.427 & 65.3 & 2.35 & 363 & \begin{tabular}{|c|}
95.5 \\
\end{tabular} & \begin{tabular}{|l|}
5.56 \\
\end{tabular} & 0.569 & 2.29 & 2.07 & \begin{tabular}{|l|}
0.0425 \\
\end{tabular} & \begin{tabular}{|l|}
0.143 \\
\end{tabular} & 0 & 2.21 \\
\hline $7-3$ & Crayfish & Hepatopancreas & \begin{tabular}{|l|}
$9 / 10 / 2001$ \\
\end{tabular} & 0.0247 & 0.0451 & 6.11 & 0.539 & 102 & 0.04 & 225 & 105 & 3.24 & 0.569 & 1.18 & 5.34 & \begin{tabular}{|l|}
0.0445 \\
\end{tabular} & 0.135 & 0 & 1.07 \\
\hline $7-3$ & Crayfish & Hepatopancreas & \begin{tabular}{|l|}
$9 / 10 / 2001$ \\
\end{tabular} & 0.0258 & 0.0451 & 6.11 & 0.539 & 102 & 0 & 225 & 105 & 3.24 & 0.569 & 1.18 & 5.34 & \begin{tabular}{|l|}
0.0445 \\
\end{tabular} & \begin{tabular}{|l|}
0.135 \\
\end{tabular} & 0 & 1.07 \\
\hline $7-4$ & Crayfish & Hepatopancreas & 9/10/2001 & 0.0147 & 0.0451 & 8.73 & 0.552 & 66.1 & \begin{tabular}{|l|}
0.04 \\
\end{tabular} & 328 & 122 & \begin{tabular}{|l|}
3.97 \\
\end{tabular} & 0.569 & 1.97 & 2.15 & \begin{tabular}{|l|}
0.0691 \\
\end{tabular} & \begin{tabular}{|l|l|}
0.137 \\
\end{tabular} & 0 & 1.57 \\
\hline $7-5$ & Crayfish & Hepatopancreas & 9/10/2001 & 0.0207 & 0.0451 & 3.80 & 0.661 & 83.3 & 0.04 & 205 & 127 & 6.78 & 0.569 & 1.21 & 4.63 & 0.0724 & 0.0951 & 0 & 1.28 \\
\hline & & & & & & & & & & & & & & & & & & & \\
\hline $9-1$ & Crayfish & Hepatopancreas & \begin{tabular}{|l|}
$8 / 27 / 2001$ \\
\end{tabular} & 0.0645 & 0.0451 & 30.5 & 0.823 & 214 & 0.977 & 979 & 274 & 8.21 & 0.569 & 3.52 & 24.7 & 0.106 & 0.314 & 0 & 6.29 \\
\hline $9-2$ & Crayfish & Hepatopancreas & $8 / 27 / 2001$ & 0.0066 & 0.0451 & 2.68 & 0.397 & 101 & \begin{tabular}{|l|}
0.04 \\
\end{tabular} & 192 & \begin{tabular}{|l|l|}
64.7 \\
\end{tabular} & 5.28 & 0.569 & 1.51 & 2.83 & \begin{tabular}{|l|}
0.0420 \\
\end{tabular} & 0.0254 & 0 & 0.671 \\
\hline $9-3$ & Crayfish & Hepatopancreas & $8 / 27 / 2001$ & 0.0258 & 0.0451 & 11.4 & 0.771 & 124 & \begin{tabular}{|l|l|}
0.690 \\
\end{tabular} & 835 & 232 & 13.1 & 0.569 & 3.52 & 10.6 & \begin{tabular}{|l|}
0.0534 \\
\end{tabular} & \begin{tabular}{|l|l|}
0.136 \\
\end{tabular} & 0 & 3.77 \\
\hline $9-4$ & Crayfish & Hepatopancreas & $8 / 27 / 2001$ & 0.0359 & 0.0451 & 3.53 & 0.657 & 32.9 & 1.26 & 233 & 118 & \begin{tabular}{|l|}
6.64 \\
\end{tabular} & 0.569 & 1.97 & 8.23 & \begin{tabular}{|l|}
0.0824 \\
\end{tabular} & 0.113 & 0 & 2.89 \\
\hline & & & & & & & & & & & & & & & & & & & \\
\hline $11-1$ & Crayfish & Hepatopancreas & 9/10/2001 & NA & 0.0451 & 6.60 & 0.855 & 77.0 & 0.476 & 643 & 131 & 5.21 & 0.569 & 2.92 & 3.28 & 0.0897 & 0.105 & 0 & 3.74 \\
\hline $11-1$ & Crayfish & Hepatopancreas & 9/10/2001 & $\mathrm{NA}$ & 0.0451 & 6.60 & 0.855 & 77.0 & 0.476 & 643 & 131 & 5.21 & 0.569 & 2.92 & 3.28 & \begin{tabular}{|l|}
0.0897 \\
\end{tabular} & \begin{tabular}{|l|} 
\\
\end{tabular} .105 & 0 & 3.74 \\
\hline $11-2$ & Crayfish & Hepatopancreas & 9/10/2001 & 0.0133 & 0.0451 & 6.38 & 0.592 & 47.5 & 0.839 & 109 & 108 & 3.68 & 0.569 & 0.510 & 3.21 & 0.148 & 0.110 & 0 & 2.46 \\
\hline $11-3$ & Crayfish & Hepatopancreas & 9/10/2001 & 0.0136 & 0.0451 & 4.40 & 0.587 & 130 & 0.258 & 438 & 82.5 & 7.03 & 0.569 & 2.75 & 4.22 & 0.0781 & 0.113 & 0 & 2.65 \\
\hline $11-4$ & Crayfish & Hepatopancreas & \begin{tabular}{|l|}
$9 / 10 / 2001$ \\
\end{tabular} & 0 & 0.0451 & 20.2 & 1.11 & 122 & \begin{tabular}{|l|}
0.04 \\
\end{tabular} & 802 & 471 & \begin{tabular}{|l|}
11.8 \\
\end{tabular} & 0.569 & 3.10 & 4.04 & 0.103 & \begin{tabular}{|l|}
0.272 \\
\end{tabular} & 0 & 2.99 \\
\hline $11-5$ & Crayfish & Hepatopancreas & 9/10/2001 & 0.0157 & 0.0451 & 7.26 & 0.787 & 180 & 0.04 & 272 & 102 & 7.49 & 0.569 & 1.04 & 3.53 & 0.126 & 0.129 & 0 & 7.81 \\
\hline & & & & & & & & & & & & & & & & & & & \\
\hline $14-1$ & Crayfish & Hepatopancreas & \begin{tabular}{|l|}
$9 / 10 / 2001$ \\
\end{tabular} & 0.0519 & 0.0451 & 13.0 & 0.625 & 204 & 9.12 & 686 & 301 & 6.77 & 0.569 & 1.65 & 1.15 & 0.171 & 0.413 & 0 & 0.707 \\
\hline $14-2$ & Crayfish & Hepatopancreas & 9/10/2001 & 0.0247 & 0.0451 & 4.69 & 0.413 & 131 & 0.04 & 372 & 224 & 5.90 & 0.569 & 1.45 & 7.09 & 0.0352 & 0.122 & 0 & 0.294 \\
\hline $14-3$ & Crayfish & Hepatopancreas & 9/10/2001 & 0.0205 & 0.0451 & 6.25 & 0.578 & 74.8 & 0.04 & 386 & 138 & 6.24 & 0.569 & 1.27 & 2.77 & \begin{tabular}{|l|l|} 
\\
\end{tabular} & 0.116 & 0 & 0.226 \\
\hline $14-4$ & Crayfish & Hepatopancreas & 9/10/2001 & 0.0175 & 0.0451 & 4.58 & 0.634 & 147 & 0.04 & 402 & 124 & 5.50 & 0.569 & 0.841 & 9.90 & \begin{tabular}{|l|}
0.0467 \\
\end{tabular} & 0.144 & 0 & 0.330 \\
\hline $14-5$ & Crayfish & Hepatopancreas & \begin{tabular}{|l|}
$9 / 10 / 2001$ \\
\end{tabular} & 0.0739 & 0.0451 & 7.39 & 0.651 & 115 & 0.04 & 730 & 206 & 9.13 & 0.569 & 2.67 & 9.73 & 0.129 & \begin{tabular}{|l|} 
\\
\end{tabular} & 0 & 0.399 \\
\hline & & & & & & & & & & & & & & & & & & & \\
\hline Vernita-1 & Crayfish & Hepatopancreas & 9/10/2001 & 0.0879 & 0.0451 & 5.95 & 0.646 & 233 & 0.253 & NA & 462 & 9.92 & 0.569 & 6.99 & 11.4 & 0.118 & 0.184 & 0 & 0.380 \\
\hline Vernita-1 & Crayfish & Hepatopancreas & 9/10/2001 & 0.0879 & 0.0451 & 5.95 & 0.646 & 233 & 0.253 & $\mathrm{NA}$ & 462 & 9.92 & 0.569 & 6.99 & 11.4 & 0.118 & \begin{tabular}{|l|} 
\\
\end{tabular} & 0 & 0.380 \\
\hline Vernita-2 & Crayfish & Hepatopancreas & 9/10/2001 & 0.0570 & 0.0451 & 8.69 & 0.636 & 408 & 1.28 & NA & 247 & 12.2 & 0.569 & 5.82 & 14.1 & 0.162 & 0.440 & 0 & 0.682 \\
\hline Vernita-3 & Crayfish & Hepatopancreas & \begin{tabular}{|l|}
$9 / 10 / 2001$ \\
\end{tabular} & 0.0188 & 0.0451 & 124 & 0.907 & 322 & 0.337 & 827 & 229 & 7.50 & 0.569 & 4.22 & 14.5 & \begin{tabular}{|l|l|}
0.0995 \\
\end{tabular} & 0.705 & 0 & 0.468 \\
\hline Vernita-4 & Crayfish & Hepatopancreas & 9/10/2001 & 0.0392 & 0.0451 & 4.64 & 0.465 & 130 & \begin{tabular}{|l|l|}
0.945 \\
\end{tabular} & 826 & 147 & \begin{tabular}{|l|}
5.30 \\
\end{tabular} & 0.569 & 4.97 & 7.43 & \begin{tabular}{|l|}
0.0740 \\
\end{tabular} & \begin{tabular}{|l|}
0.145 \\
\end{tabular} & 0 & 0.264 \\
\hline Vernita-5 & Crayfish & Hepatopancreas & 9/10/2001 & 0.0112 & 0.0451 & 9.04 & 0.872 & 267 & 0.04 & 994 & 209 & 5.85 & 0.569 & 2.82 & 9.40 & \begin{tabular}{|l|}
0.0983 \\
\end{tabular} & \begin{tabular}{|l|}
0.339 \\
\end{tabular} & 0 & 0.643 \\
\hline
\end{tabular}




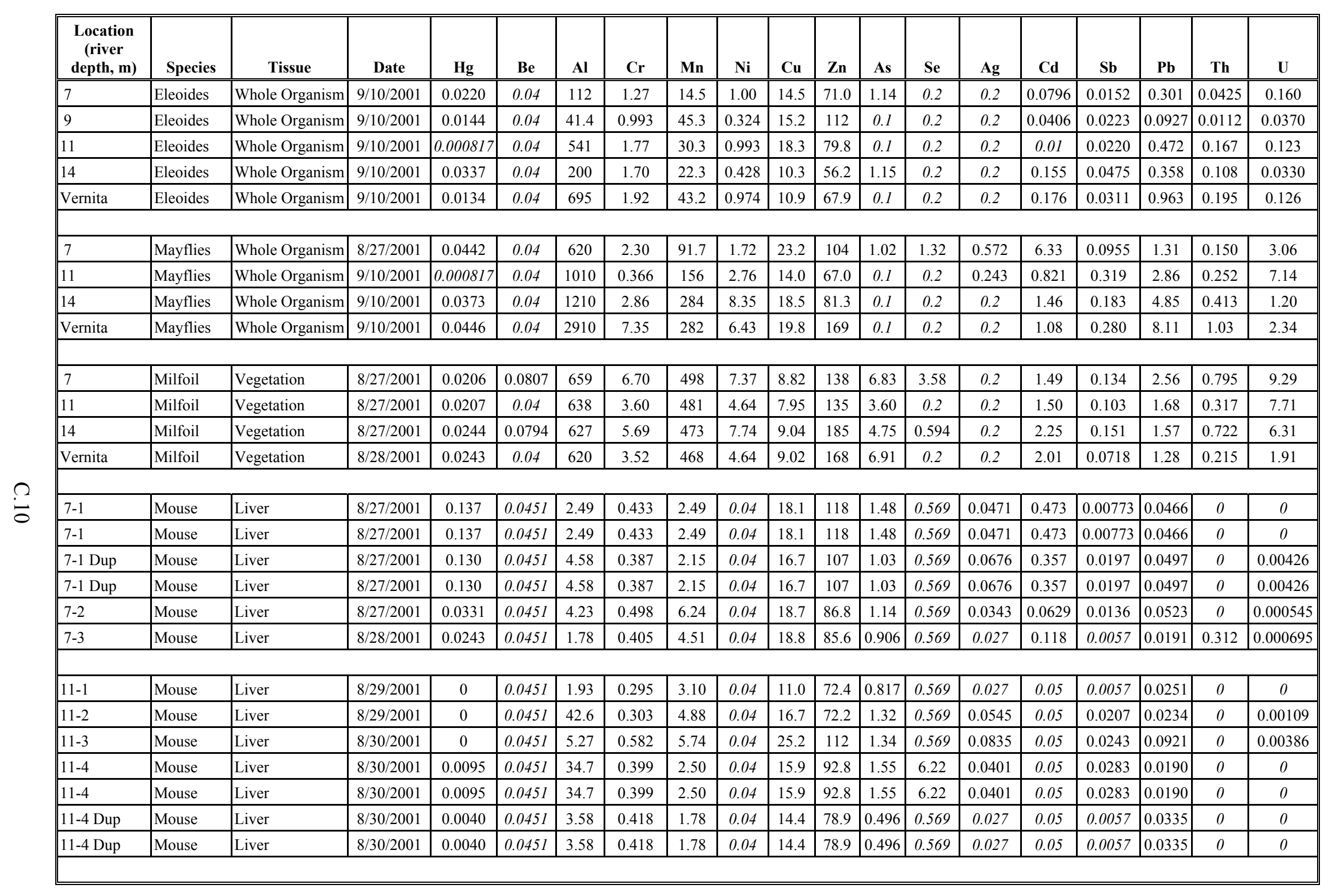




\begin{tabular}{|c|c|c|c|c|c|c|c|c|c|c|c|c|c|c|c|c|c|c|c|}
\hline $\begin{array}{c}\text { Location } \\
\text { (river } \\
\text { depth, m) }\end{array}$ & Species & Tissue & Date & $\mathrm{Hg}$ & Be & Al & $\mathrm{Cr}$ & Mn & $\mathbf{N i}$ & $\mathbf{C u}$ & $\mathbf{Z n}$ & As & Se & Ag & $\mathrm{Cd}$ & Sb & $\mathbf{P b}$ & Th & $\mathbf{U}$ \\
\hline 14-1 & Mouse & Liver & \begin{tabular}{|l|}
$8 / 28 / 2001$ \\
\end{tabular} & \begin{tabular}{|l|}
0.0363 \\
\end{tabular} & 0.0451 & 3.00 & 0.822 & 2.78 & 0.04 & 22.2 & 101 & \begin{tabular}{|l|}
1.01 \\
\end{tabular} & 0.569 & 0.027 & \begin{tabular}{|l|l|}
0.161 \\
\end{tabular} & \begin{tabular}{|l|}
0.0141 \\
\end{tabular} & \begin{tabular}{|l|l|}
0.0593 \\
\end{tabular} & 0 & 0 \\
\hline $14-1$ & Mouse & Liver & \begin{tabular}{|l|}
$8 / 28 / 2001$ \\
\end{tabular} & 0.0363 & 0.0451 & 3.00 & 0.822 & 2.78 & 0.04 & 22.2 & 101 & 1.01 & 0.569 & 0.027 & 0.161 & \begin{tabular}{|l|}
0.0141 \\
\end{tabular} & 0.0593 & 0 & 0 \\
\hline 14-1 Dup & Mouse & Liver & \begin{tabular}{|l|}
$8 / 28 / 2001$ \\
\end{tabular} & 0.0406 & 0.0451 & 12.9 & 0.368 & 2.73 & 0.04 & 18.9 & 93.3 & 0.746 & 0.569 & 0.0462 & \begin{tabular}{|l|l|}
0.122 \\
\end{tabular} & 0.00935 & 0.0557 & 0 & 0.00208 \\
\hline 14-1 Dup & Mouse & Liver & $8 / 28 / 2001$ & 0.0406 & 0.0451 & 12.9 & 0.368 & 2.73 & 0.04 & 18.9 & 93.3 & 0.746 & 0.569 & 0.0462 & \begin{tabular}{|l|l|}
0.122 \\
\end{tabular} & 0.00935 & 0.0557 & 0 & 0.00208 \\
\hline $14-2$ & Mouse & Liver & \begin{tabular}{|l|}
$8 / 28 / 2001$ \\
\end{tabular} & 0.0130 & 0.0451 & 10.2 & 0.443 & 3.97 & 0.04 & 15.0 & 83.1 & 1.02 & 0.569 & 0.027 & \begin{tabular}{|l|l|}
0.0936 \\
\end{tabular} & 0.0057 & 0.0375 & 0 & 0 \\
\hline $14-2$ & Mouse & Liver & $8 / 28 / 2001$ & 0.0130 & 0.0451 & 10.2 & 0.443 & 3.97 & 0.04 & 15.0 & 83.1 & 1.02 & 0.569 & 0.027 & \begin{tabular}{l|l|}
0.0936 \\
\end{tabular} & 0.0057 & 0.0375 & 0 & 0 \\
\hline 14-2 Dup & Mouse & Liver & \begin{tabular}{|l|}
$8 / 28 / 2001$ \\
\end{tabular} & 0.0165 & 0.0451 & 12.6 & 0.513 & 3.89 & 0.04 & 14.0 & 82.0 & 0.674 & 0.569 & 0.027 & \begin{tabular}{|l|l}
0.0735 \\
\end{tabular} & \begin{tabular}{|l|}
0.0145 \\
\end{tabular} & 0.0568 & 0 & 0 \\
\hline 14-2 Dup & Mouse & Liver & $8 / 28 / 2001$ & 0.0165 & 0.0451 & 12.6 & 0.513 & 3.89 & 0.04 & 14.0 & 82.0 & 0.674 & 0.569 & 0.027 & \begin{tabular}{l|l|}
0.0735 \\
\end{tabular} & \begin{tabular}{|l|}
0.0145 \\
\end{tabular} & 0.0568 & 0 & 0 \\
\hline 7 & Mulberry & Vegetation & \begin{tabular}{|l|}
$8 / 27 / 2001$ \\
\end{tabular} & \begin{tabular}{|l|}
0.0343 \\
\end{tabular} & 0.04 & 117 & 0.988 & 8.23 & 1.30 & 4.49 & 14.9 & \begin{tabular}{|l|}
0.468 \\
\end{tabular} & 0.2 & 0.2 & 0.01 & \begin{tabular}{|l|}
0.0253 \\
\end{tabular} & \begin{tabular}{|l|l|}
0.199 \\
\end{tabular} & \begin{tabular}{|l|}
0.0383 \\
\end{tabular} & 0.0798 \\
\hline 9 & Mulberry & Vegetation & \begin{tabular}{|l|}
$8 / 27 / 2001$ \\
\end{tabular} & 0.0296 & 0.04 & 101 & 1.03 & 16.1 & 1.47 & 4.43 & 18.2 & 0.445 & 0.815 & 0.2 & 0.01 & \begin{tabular}{|l|}
0.0216 \\
\end{tabular} & 0.0645 & \begin{tabular}{|l|l|}
0.0248 \\
\end{tabular} & 0.123 \\
\hline 11 & Mulberry & Vegetation & $8 / 27 / 2001$ & 0.00800 & 0.04 & 52.6 & 0.634 & 15.5 & 0.878 & 1.99 & 14.9 & 0.1 & 0.2 & 0.2 & 0.01 & 0.0105 & 0.0666 & \begin{tabular}{|l|l}
0.0246 \\
\end{tabular} & 0.0201 \\
\hline 14 & Mulberry & Vegetation & $8 / 27 / 2001$ & 0.00380 & 0.04 & 41.9 & 0.436 & 8.61 & 3.00 & 9.22 & 31.6 & 0.1 & 0.2 & 0.2 & 0.01 & \begin{tabular}{|l|}
0.0170 \\
\end{tabular} & 0.0570 & \begin{tabular}{|l|l|}
0.0184 \\
\end{tabular} & 0.01 \\
\hline Vernita & Mulberry & Vegetation & $8 / 28 / 2001$ & 0.0398 & 0.04 & 79.8 & 1.07 & 38.9 & 3.09 & 3.70 & 36.8 & 1.54 & 3.22 & 0.2 & 0.01 & 0.0224 & \begin{tabular}{|l|l|} 
& 0.174 \\
\end{tabular} & 0.0166 & 0.01 \\
\hline 9 & Periphyton & Algae & $8 / 27 / 2001$ & 0.0140 & 0.146 & 626 & 13.5 & 472 & 12.1 & 103 & 104 & | 6.96 & 02 & 0.303 & $\mid 0.760$ & 0.147 & 959 & 267 & 366 \\
\hline 11 & Periphyton & Algae & \begin{tabular}{|l|}
$8 / 27 / 2001$ \\
\end{tabular} & \begin{tabular}{|l|}
0.0575 \\
\end{tabular} & 0.240 & 633 & 21.9 & 478 & 17.0 & 24.0 & 170 & \begin{tabular}{|l|}
10.7 \\
\end{tabular} & \begin{tabular}{|l|}
0.708 \\
\end{tabular} & 0.2 & 2.36 & 0.212 & 7.40 & 3.51 & 10.7 \\
\hline 11 & Periphyton & Algae & $8 / 27 / 2001$ & 0.0513 & 0.264 & 646 & 24.6 & 488 & 18.1 & 25.0 & 173 & 10.8 & 0.2 & 0.236 & 2.26 & 0.237 & 6.25 & 4.60 & 9.19 \\
\hline 14 & Periphyton & Algae & $8 / 27 / 2001$ & 0.0333 & 0.214 & 646 & 21.6 & 443 & 16.7 & 26.6 & 174 & 10.6 & 0.2 & 0.240 & 2.17 & 0.214 & 12.1 & 5.00 & 3.60 \\
\hline $7-1$ & Sculpin & Liver & \begin{tabular}{|l|}
$8 / 27 / 2001$ \\
\end{tabular} & 0.250 & 0.390 & 6.28 & 0.151 & 3.54 & 0.04 & 16.2 & 188 & \begin{tabular}{|l|}
3.31 \\
\end{tabular} & 0.569 & 0.0866 & 2.07 & \begin{tabular}{|l|}
0.00695 \\
\end{tabular} & \begin{tabular}{|l|l|}
0.396 \\
\end{tabular} & 13.0 & 0.0169 \\
\hline $7-2$ & Sculpin & Liver & $8 / 27 / 2001$ & 0.236 & 0.349 & 5.27 & 0.00931 & 6.70 & 0.04 & 20.2 & 206 & 4.12 & 0.569 & 0.0845 & 6.36 & 0.0104 & \begin{tabular}{|l|}
0.153 \\
\end{tabular} & 16.0 & 0.0482 \\
\hline $7-3$ & Sculpin & Liver & \begin{tabular}{|l|}
$8 / 27 / 2001$ \\
\end{tabular} & 0.117 & 0.281 & 5.44 & 0 & 4.20 & 0.04 & 10.0 & 166 & 3.34 & 0.569 & 0.0556 & 3.61 & \begin{tabular}{|l|}
0.0121 \\
\end{tabular} & \begin{tabular}{|l|}
0.229 \\
\end{tabular} & 9.53 & 0.00708 \\
\hline $7-4$ & Sculpin & Liver & $8 / 27 / 2001$ & 0.120 & 1.42 & 28.4 & 0 & 8.81 & 0.04 & 60.3 & 291 & 7.59 & 0.569 & 0.368 & 6.48 & 0.0794 & \begin{tabular}{|l|l|}
0.423 \\
\end{tabular} & 37.0 & 0.0304 \\
\hline $7-5$ & Sculpin & Liver & $8 / 27 / 2001$ & 0.116 & 0.0451 & 20.1 & 3.81 & 6.50 & 0.04 & 29.7 & 169 & 11.5 & 0.569 & 0.289 & 1.91 & 0.0295 & \begin{tabular}{|l|l|} 
& 0.450 \\
\end{tabular} & 0 & 0.0365 \\
\hline $11-1$ & Sculpin & Liver & $8 / 27 / 2001$ & 0.388 & 0.0451 & 14.0 & 1.40 & 5.30 & 0.04 & 19.3 & 252 & \begin{tabular}{|l|l|}
9.01 \\
\end{tabular} & 0.569 & 0.178 & 10.3 & 0.119 & \begin{tabular}{|l|l|}
0.314 \\
\end{tabular} & 0 & 0.00777 \\
\hline $14-1$ & Sculpin & Liver & \begin{tabular}{|l|}
$8 / 27 / 2001$ \\
\end{tabular} & 0.872 & 0.0451 & 6.40 & 0.397 & 6.56 & 0.04 & 36.2 & 463 & \begin{tabular}{|l|}
2.78 \\
\end{tabular} & 0.569 & 0.115 & 17.1 & \begin{tabular}{|l|}
0.0139 \\
\end{tabular} & \begin{tabular}{|l|l|}
0.142 \\
\end{tabular} & 0 & 0.0196 \\
\hline $14-2$ & Sculpin & Liver & \begin{tabular}{|l|}
$8 / 27 / 2001$ \\
\end{tabular} & 0.355 & 0.0451 & 63.7 & 2.25 & 6.88 & 0.04 & 57.7 & 373 & 12.3 & 0.569 & 0.314 & 15.8 & \begin{tabular}{|l|}
0.0879 \\
\end{tabular} & \begin{tabular}{|l|}
0.556 \\
\end{tabular} & 0 & 0.0175 \\
\hline$\overline{14-3}$ & Sculpin & Liver & \begin{tabular}{|l|}
$8 / 27 / 2001$ \\
\end{tabular} & \begin{tabular}{|l|}
0.0879 \\
\end{tabular} & 0.0451 & 7.78 & 0.276 & 3.08 & 0.04 & 5.82 & 94.9 & 5.05 & 0.569 & 0.0800 & 1.62 & 0.0348 & \begin{tabular}{|l|}
0.158 \\
\end{tabular} & 0 & 0 \\
\hline
\end{tabular}




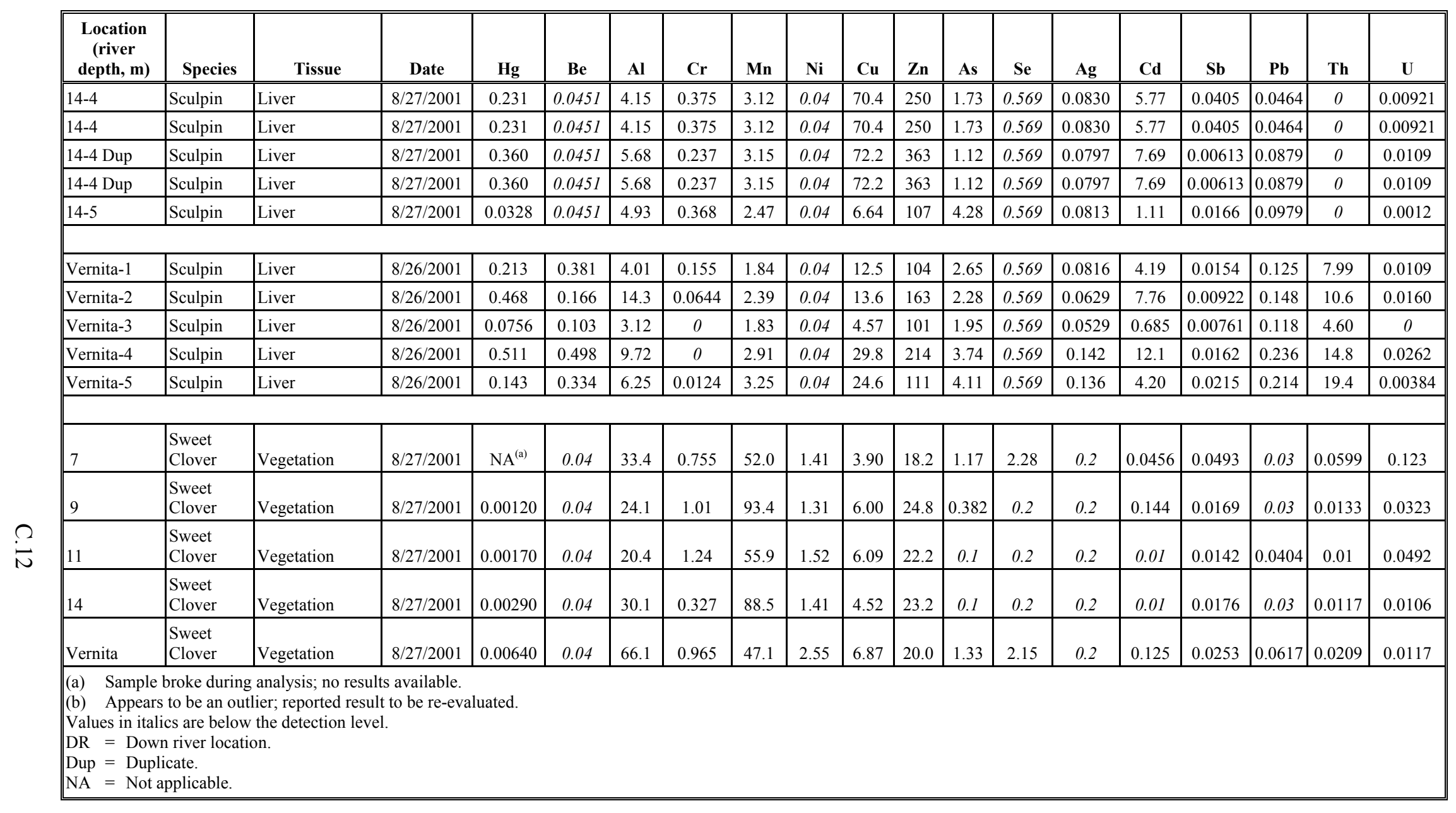


Table C.6. Specific Conductivity Measurements for 300 Area and Vernita Bridge Near-Shore River Water, Cross-River Transects, Riverbank Springs, and Shallow Groundwater Samples

\begin{tabular}{|c|c|c|c|c|c|c|c|}
\hline \multirow[b]{3}{*}{ Location } & \multirow{3}{*}{ Date } & \multicolumn{6}{|c|}{ Specific Conductivity $(\boldsymbol{\mu S} / \mathrm{cm})$} \\
\hline & & \multirow[b]{2}{*}{ Spring } & \multicolumn{4}{|c|}{ River Depth } & \\
\hline & & & $0.25 \mathrm{~m}$ & $0.5 \mathrm{~m}$ & $1 \mathrm{~m}$ & $1.5 \mathrm{~m}$ & \\
\hline Vernita & $08 / 27 / 2001$ & & 133 & 129 & 129 & 130 & \\
\hline Location 7 & $08 / 27 / 2001$ & 327 & 245 & 199 & 166 & 160 & \\
\hline Location $7 \mathrm{DR}$ & $08 / 27 / 2001$ & & 162 & 150 & 148 & 139 & \\
\hline Location $7 / 9$ & $08 / 27 / 2001$ & & 141 & & & & \\
\hline Location 9 & $08 / 27 / 2001$ & 390 & 265 & 146 & 136 & 133 & \\
\hline Location $9 \mathrm{DR}$ & $08 / 27 / 2001$ & & 155 & 157 & 143 & 135 & \\
\hline Location $9 / 11$ & $08 / 27 / 2001$ & & 133 & & & & \\
\hline Location 11 & $08 / 27 / 2001$ & & 147 & 132 & 141 & 132 & \\
\hline Location $11 \mathrm{DR}$ & $08 / 27 / 2001$ & & 145 & 134 & 132 & 132 & \\
\hline Location 14 & $08 / 27 / 2001$ & & 178 & 163 & 142 & 141 & \\
\hline \multicolumn{8}{|c|}{ Cross-River Transects } \\
\hline Location & Date & Station 1 & Station 2 & Station 3 & Station 5 & Station 7 & Station 10 \\
\hline Vernita Bridge & $09 / 07 / 2001$ & 135 & & 132 & & 133 & 140 \\
\hline 300 Area HRM 41.5 & $09 / 13 / 2001$ & 133 & & & & & \\
\hline 300 Area HRM 42.2 & $09 / 13 / 2001$ & 144 & & & & & \\
\hline 300 Area HRM 42.5 & $09 / 13 / 2001$ & 132 & & & & & \\
\hline 300 Area HRM 42.9 & $09 / 13 / 2001$ & 131 & & & & & \\
\hline 300 Area HRM 43.1 & $09 / 13 / 2001$ & 130 & 130 & 131 & 132 & 136 & 186 \\
\hline \multicolumn{8}{|c|}{ Shallow Groundwater and Riverbank Springs } \\
\hline $\begin{array}{c}\text { Location } \\
\text { (river depth, m) }\end{array}$ & Date & $\mu \mathrm{S} / \mathrm{cm}$ & & & & & \\
\hline Spring 7 & $09 / 18 / 2001$ & 353 & & & & & \\
\hline $7-1(0.76)$ & $09 / 18 / 2001$ & 360 & & & & & \\
\hline $7-1(1.2)$ & $09 / 18 / 2001$ & 358 & & & & & \\
\hline $7-1(1.8)$ & $09 / 18 / 2001$ & 390 & & & & & \\
\hline $7-2(0.6)$ & $09 / 18 / 2001$ & 384 & & & & & \\
\hline $7-2(1.2)$ & $09 / 18 / 2001$ & 390 & & & & & \\
\hline Spring 9 & 09/17/2001 & 357 & & & & & \\
\hline $9-1(0.6)$ & 09/17/2001 & 344 & & & & & \\
\hline $9-1(1.2)$ & $09 / 17 / 2001$ & 387 & & & & & \\
\hline $9-2(0.6)$ & $09 / 17 / 2001$ & 388 & & & & & \\
\hline $9-2(1.4)$ & $09 / 17 / 2001$ & 387 & & & & & \\
\hline $9-3(1.7)$ & 09/17/2001 & 360 & & & & & \\
\hline
\end{tabular}




\section{Appendix C References}

Poston, T. M., R. W. Hanf, R. L. Dirkes, and L. F. Morasch (eds.). 2001. Hanford Site Environmental

Report for Calendar Year 2000. PNNL-13486, Pacific Northwest National Laboratory, Richland, Washington.

WAC 173-201A-040. Toxic Substances. Washington Administrative Code, Olympia, Washington. 


\section{Appendix D}

Results for Split Radiological Samples (analyzed by both Washington State Department of Health and Pacific Northwest National Laboratory) 


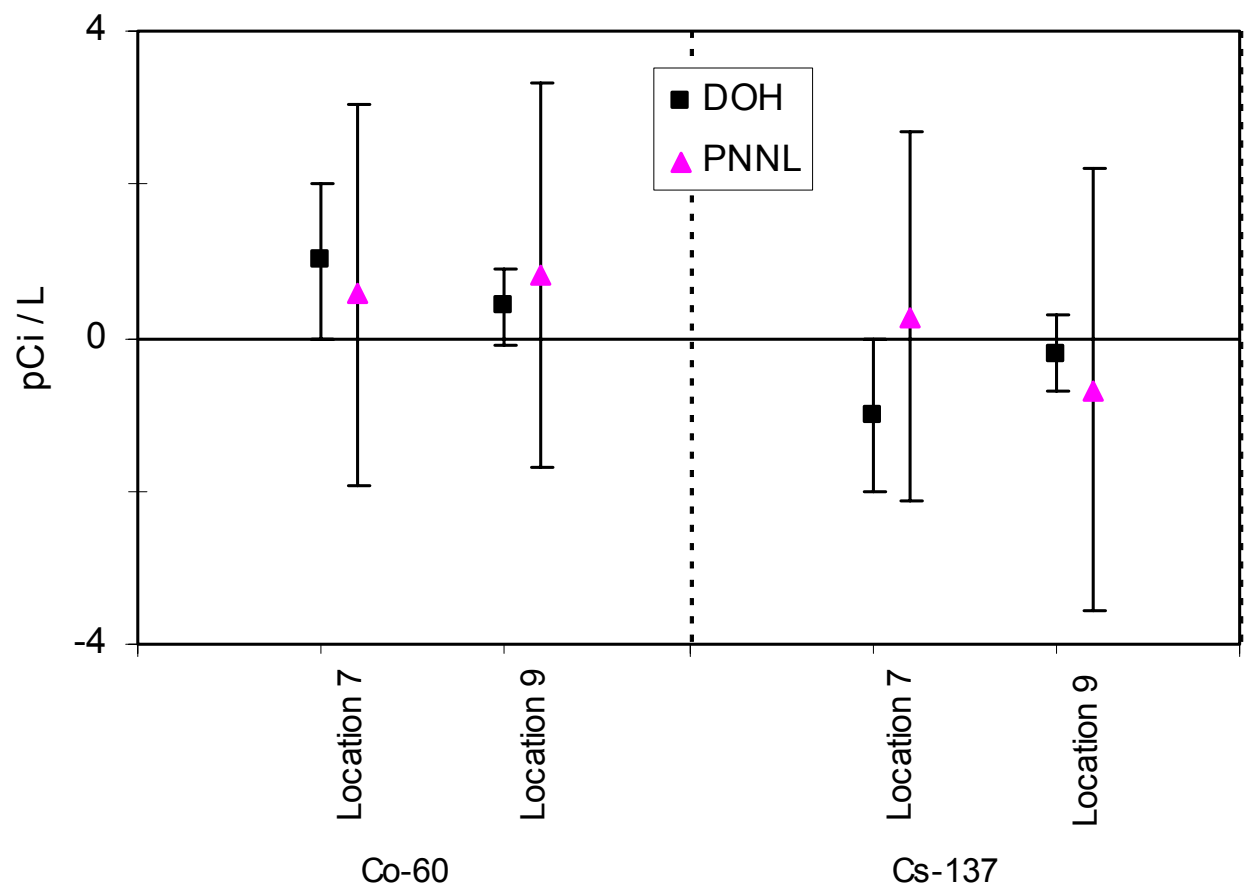

Figure D.1. Split Results: Gamma in Surface Water

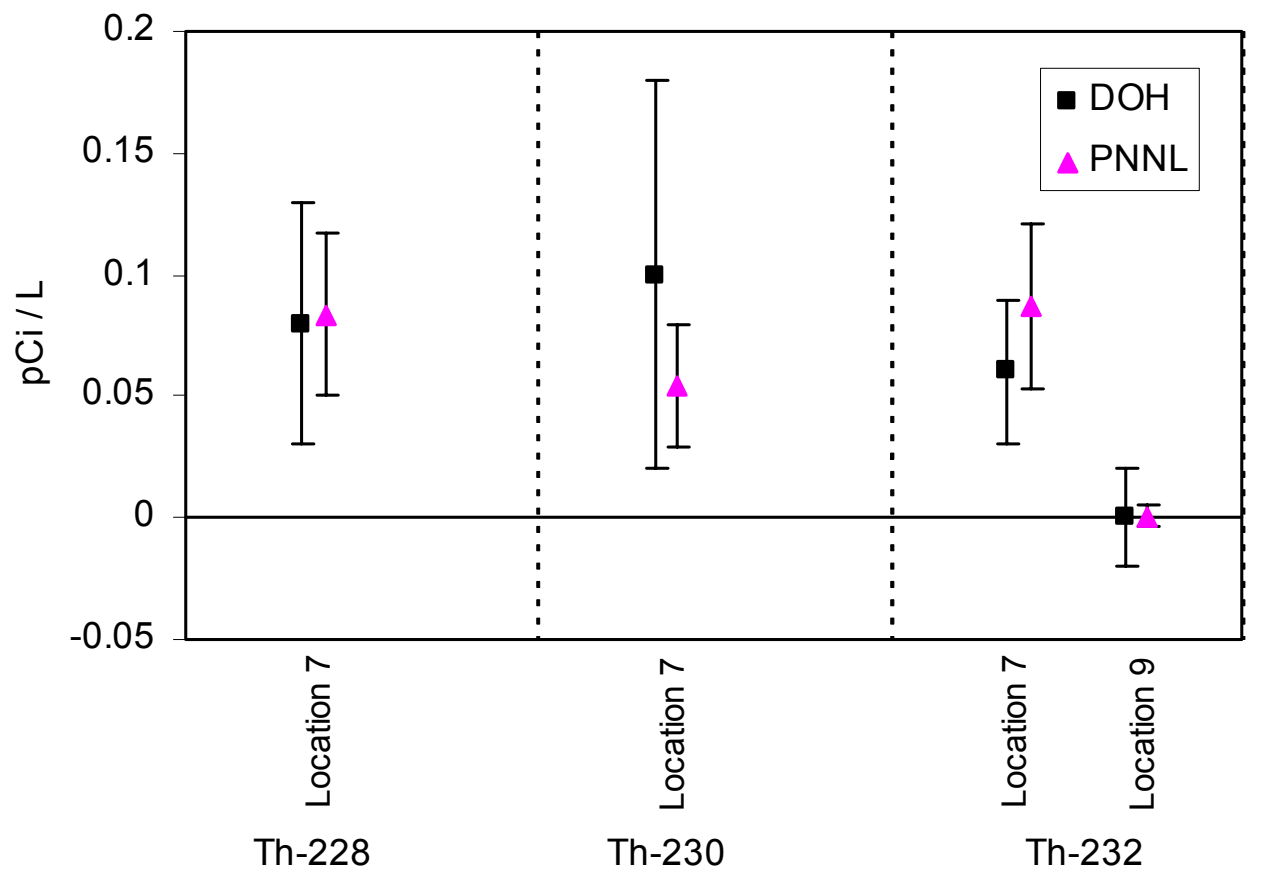

Figure D.2. Split Results: Thorium in Surface Water

D. 1 


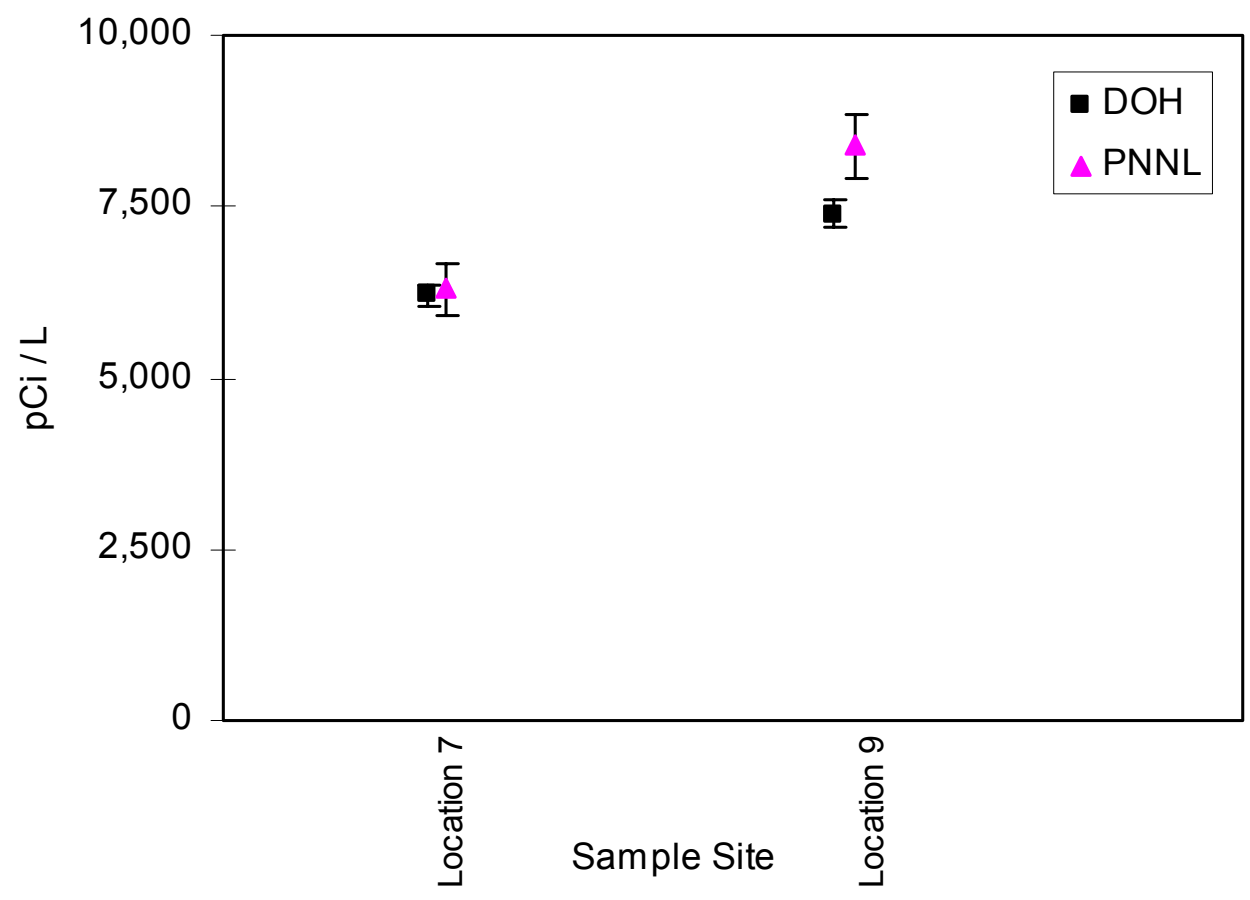

Figure D.3. Split Results: Tritium in Surface Water

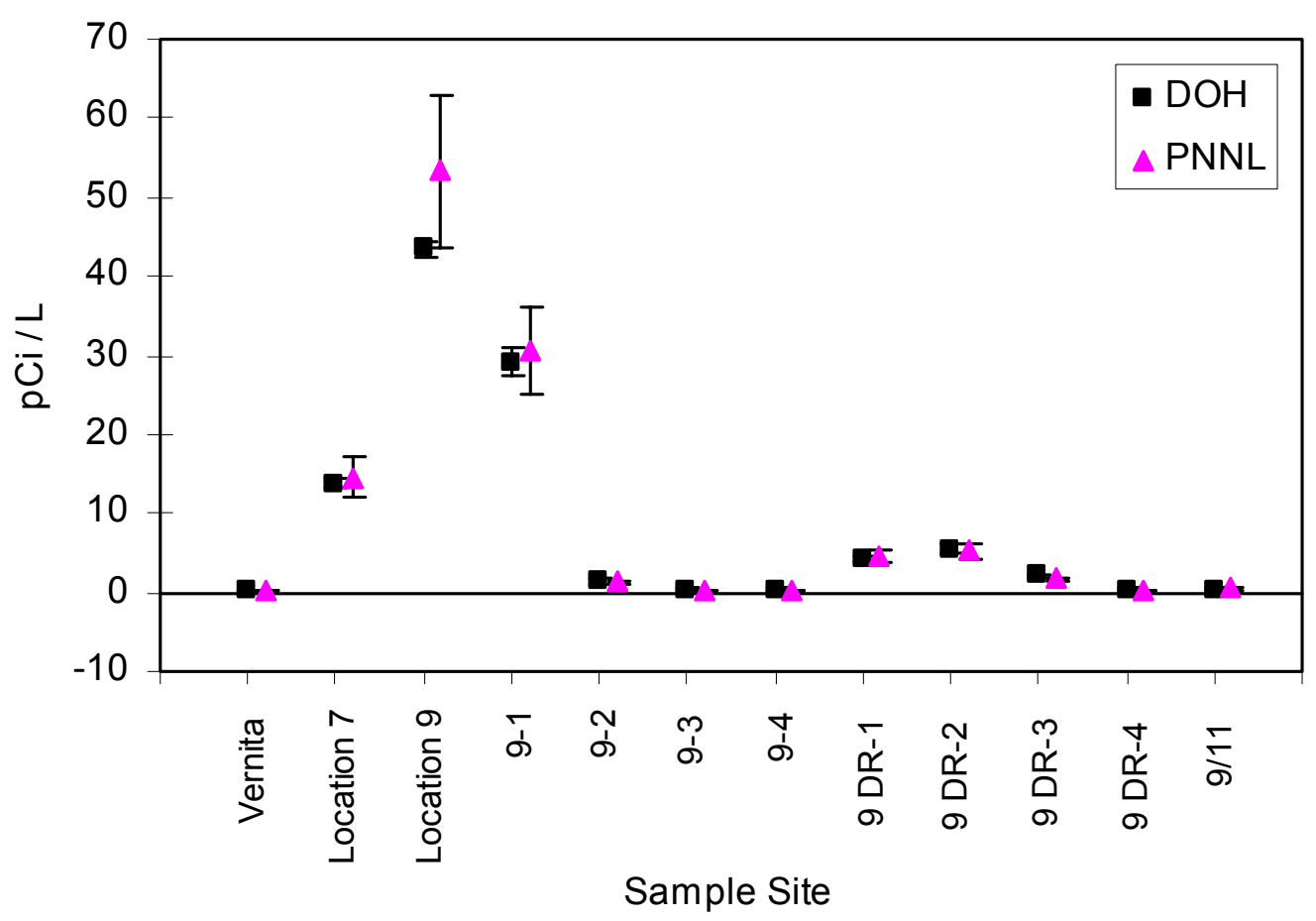

Figure D.4. Split Results: Uranium-234 in Surface Water

D. 2 


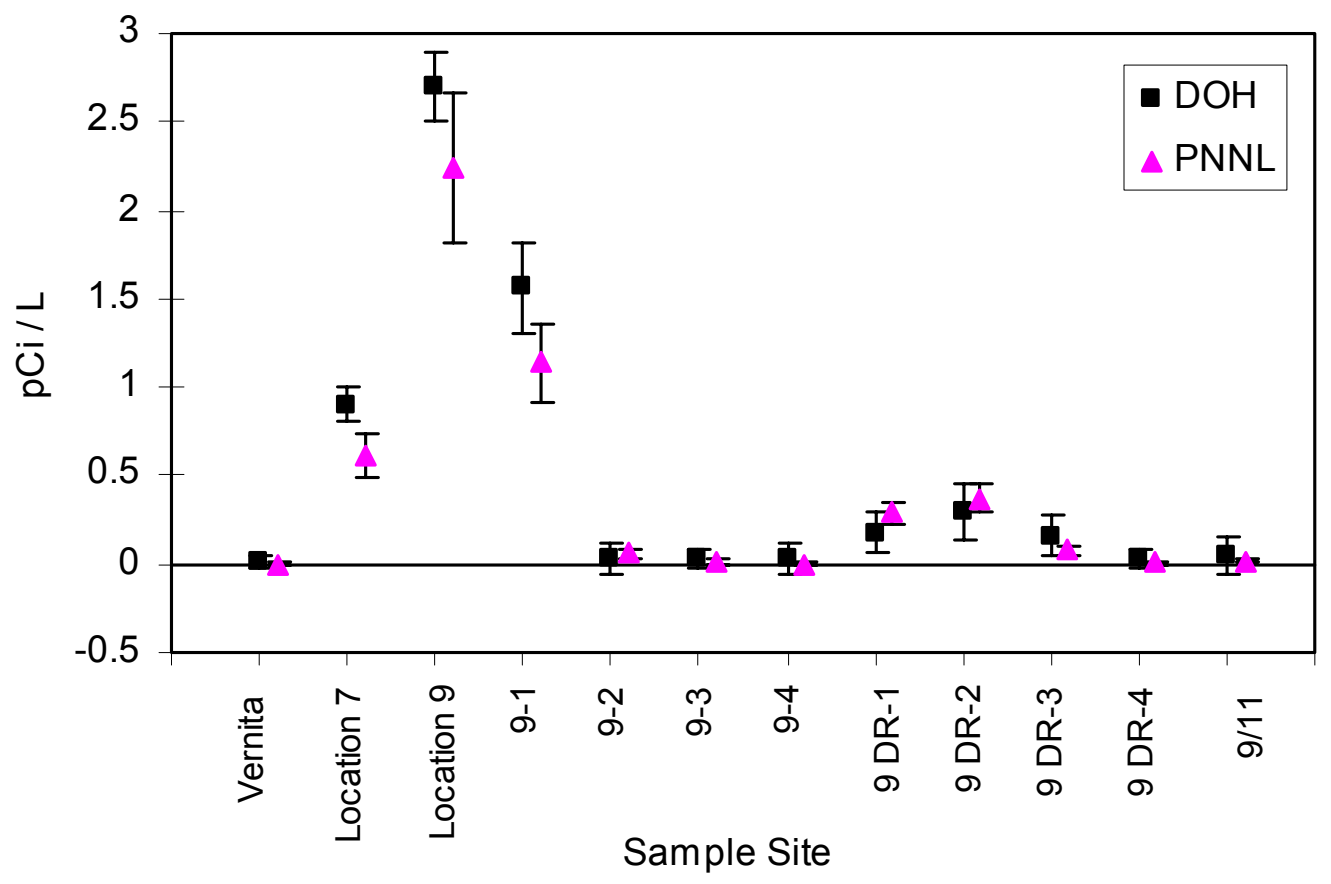

Figure D.5. Split Results: Uranium-235 in Surface Water

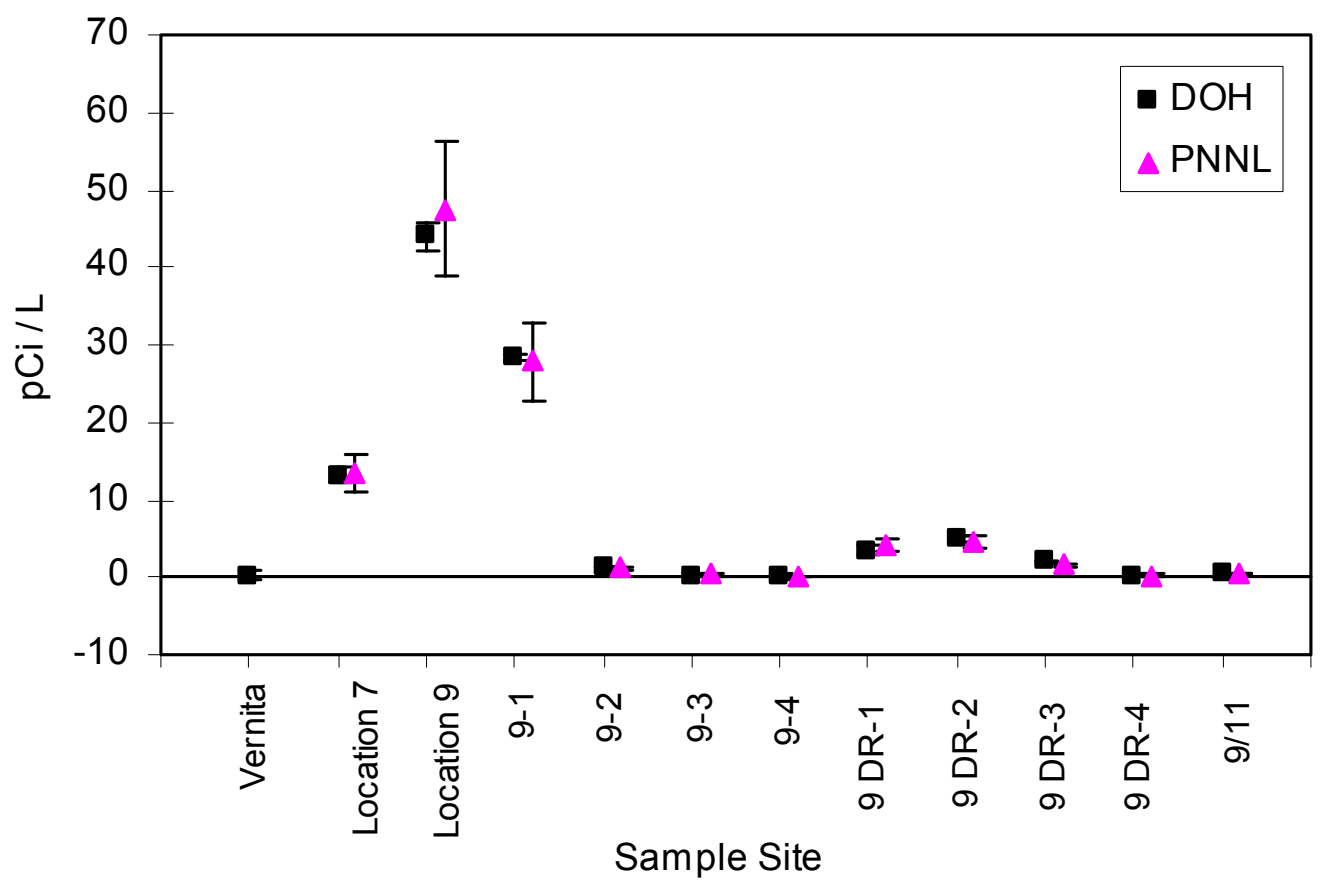

Figure D.6. Split Results: Uranium-238 in Surface Water 


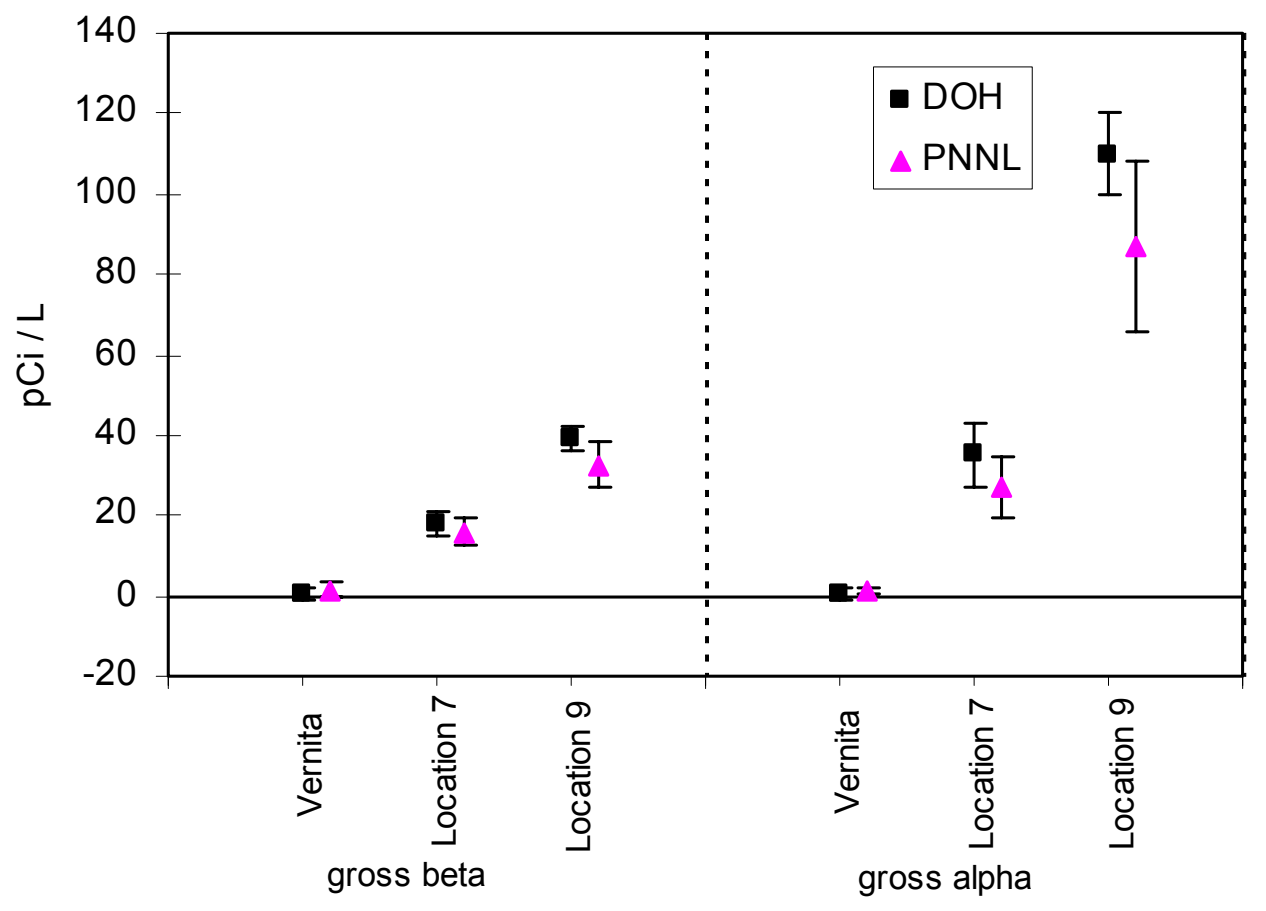

Figure D.7. Split Results: Gross Beta/Alpha in Surface Water

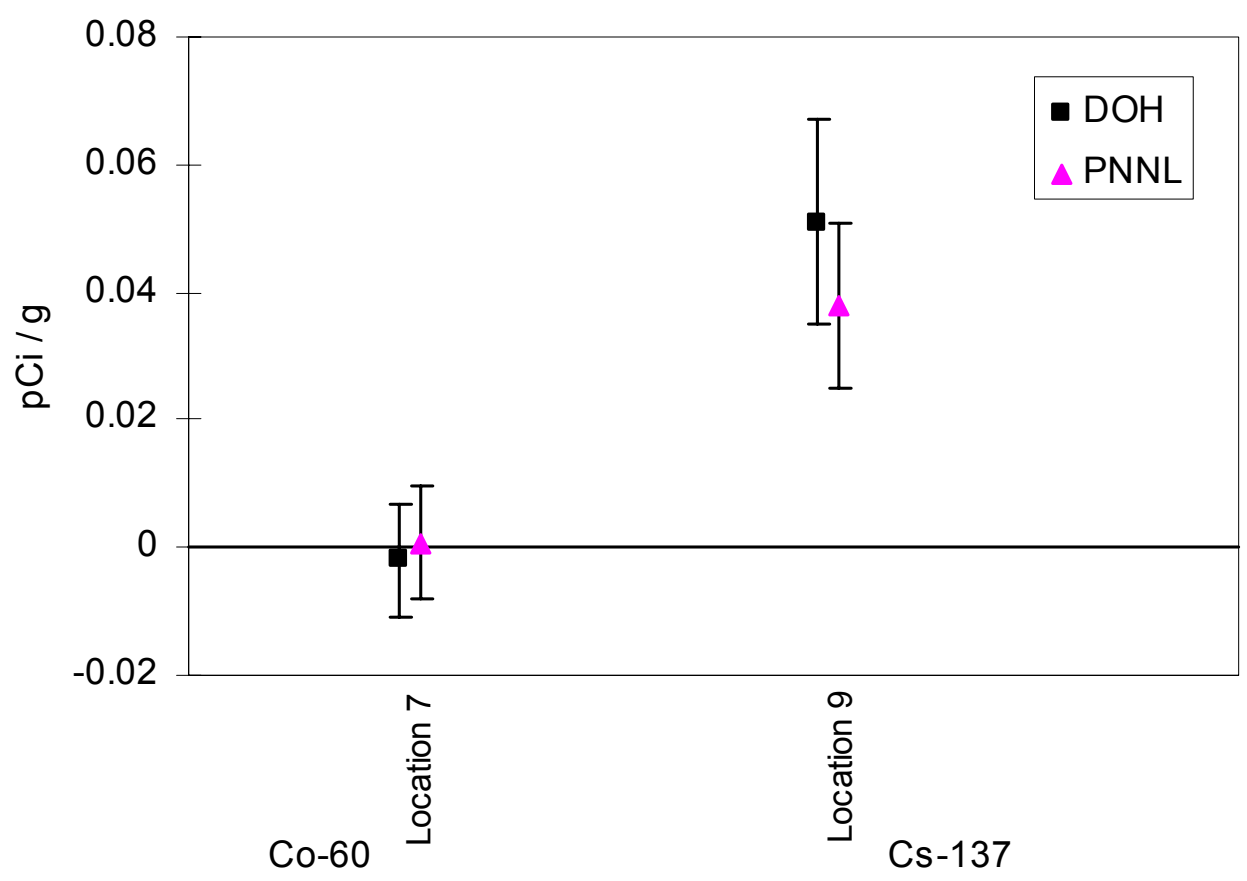

Figure D.8. Split Results: Gamma in Sediment 


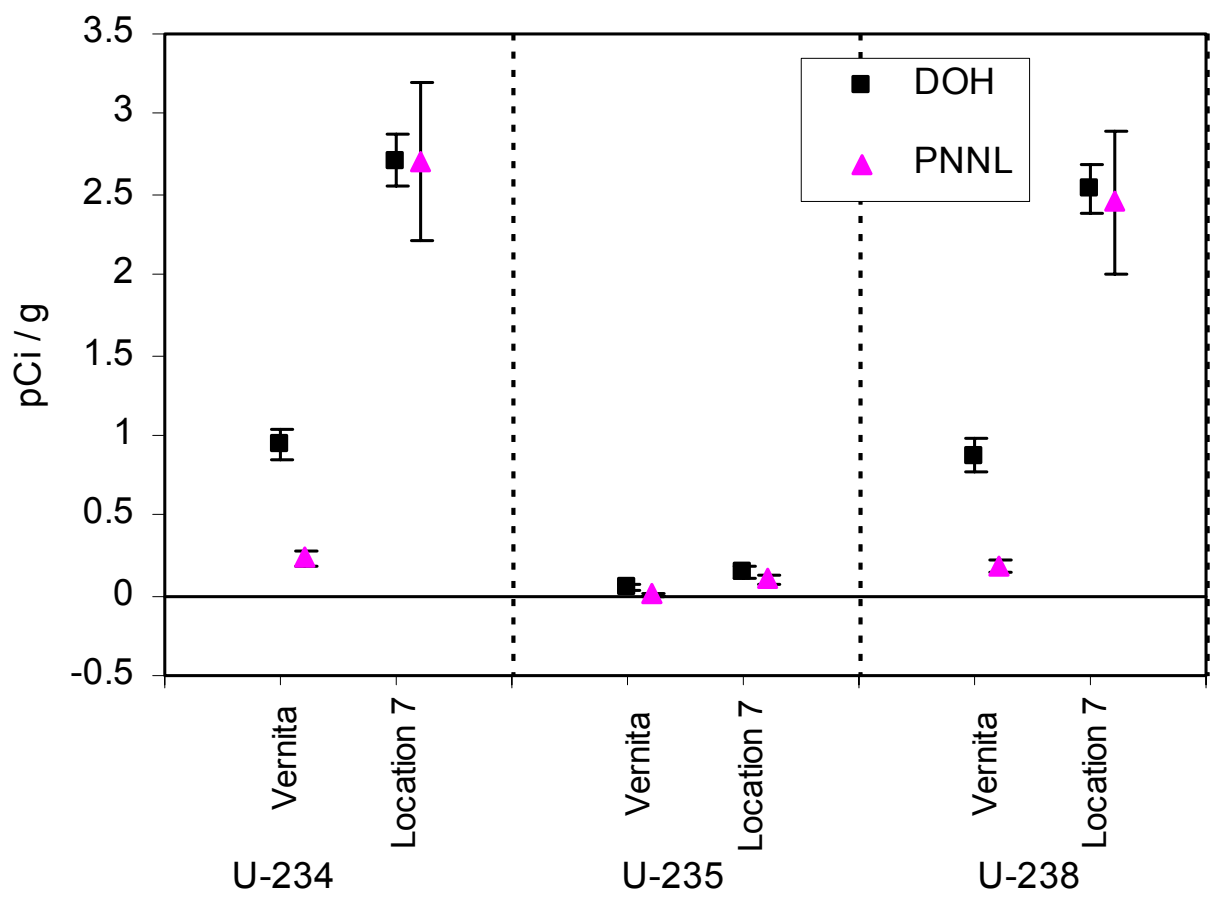

Figure D.9. Split Results: Uranium in Sediment

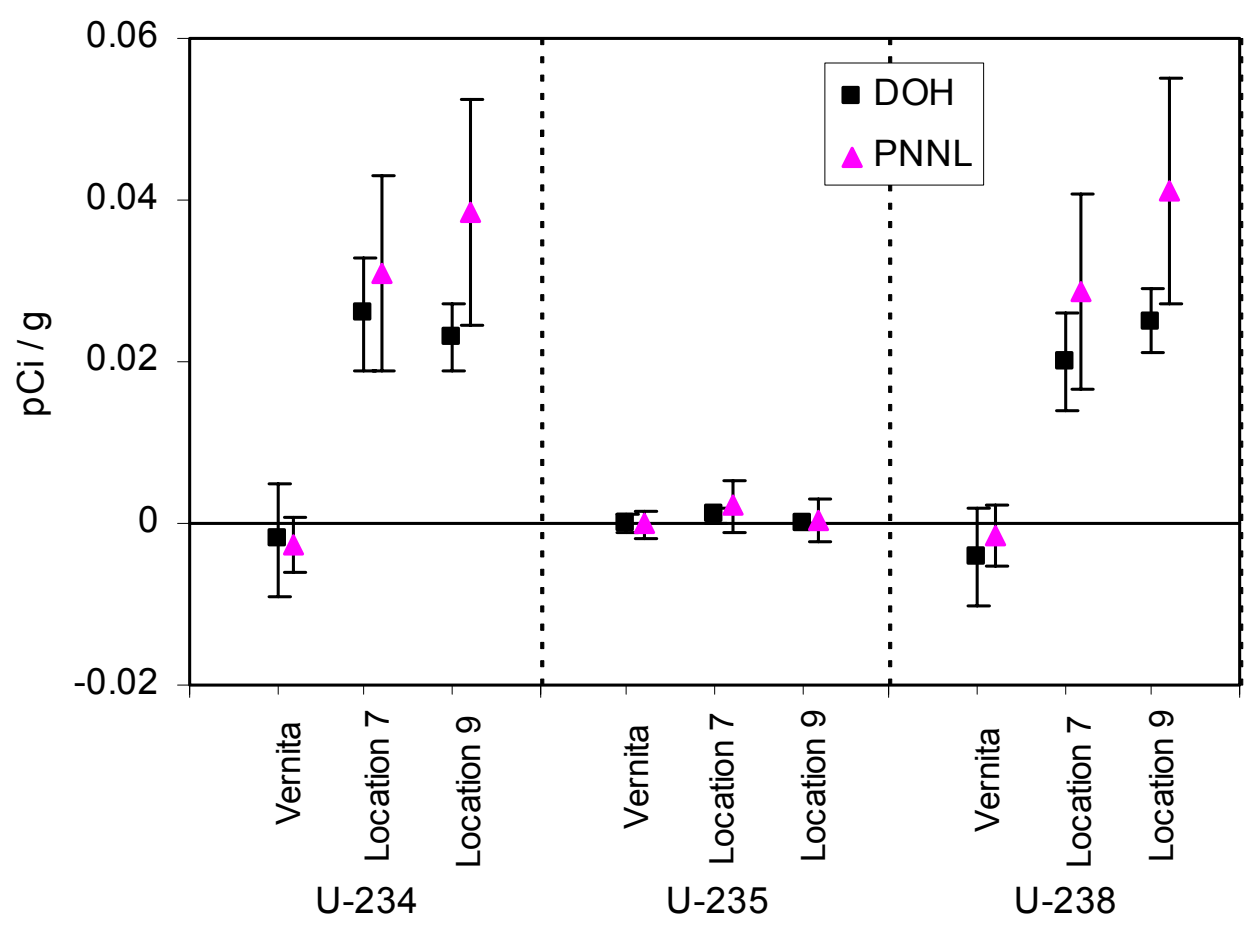

Figure D.10. Split Results: Uranium in Mulberry

D.5 


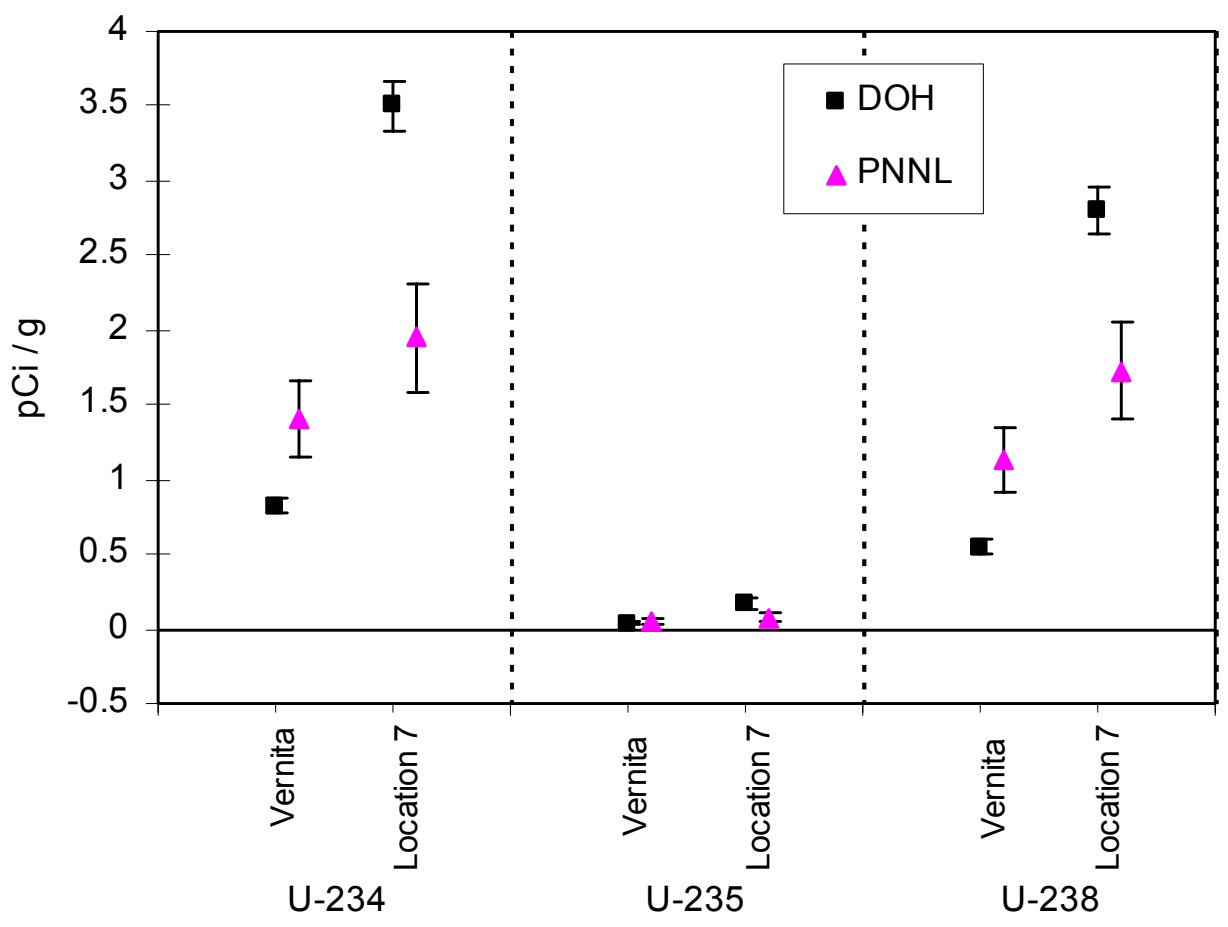

Figure D.11. Split Results: Uranium in Milfoil 


\section{Appendix E}

\section{BDAC Screening and Species-Specific Dose Calculations}




\section{Appendix E}

\section{BDAC Screening and Species-Specific Dose Calculations}

Certain water and sediment samples were split and half the original samples were sent for uranium analysis to be performed using an inductively coupled-mass spectrometer (ICP-MS). The results from the ICP-MS analyses were reported in terms of micrograms uranium per unit mass of sample. In selected water and sediment samples, a miniscule amount of uranium-236 was identified and uranium-236 was included in this screening assessment. Conversion factors were used to change units of samples analyzed by mass spectroscopic analysis to activity concentrations used in the Biota Dose Assessment Committee (BDAC) screening analyses (Table E.1).

Table E.1. Conversion Factors for Uranium Isotopes

\begin{tabular}{||c|c|c|c|c||}
\hline Isotope & $\mathrm{U}-234$ & $\mathrm{U}-235$ & $\mathrm{U}-236$ & $\mathrm{U}-238$ \\
\hline \hline $\mathrm{pCi} / \mu \mathrm{g}$ & $6.24 \mathrm{E}+03$ & $2.16 \mathrm{E}+00$ & $6.49 \mathrm{E}+01$ & $3.35 \mathrm{E}-01$ \\
\hline
\end{tabular}

\section{E.1 BDAC Screen with Uranium ICP-MS Data}

In the screening dose assessment of the mass spectroscopic uranium data, radioanalytical data for tritium, strontium-90, and technetium-99 were used in addition to the converted ICP-MS uranium data. The activity concentration results for uranium were higher than the converted ICP-MS data. Results of this screening indicate that the inclusion of uranium-236 did not significantly contribute to dose from uranium isotopes. Overall, the sum of fractions was lower than the initial assessment (see Section 7.1) and the sum of fractions did not fail the 1.0 screening (Table E.2).

Table E.2. Results of 300 Area Shoreline Study Screening Assessment of Radiological Doses to Biota Using Mass Spectroscopic Uranium Data and the Biota Dose Calculator

\begin{tabular}{|c|c|c|c|c|c|}
\hline Nuclide & $\begin{array}{c}\text { Water Limit } \\
\mathrm{pCi} / \mathrm{L}\end{array}$ & $\begin{array}{l}\text { Water Partial } \\
\text { Fraction }\end{array}$ & $\begin{array}{c}\text { Sediment Limit } \\
\text { pCi } / \mathrm{g}\end{array}$ & $\begin{array}{c}\text { Sediment } \\
\text { Partial Fraction }\end{array}$ & $\begin{array}{c}\text { Combined Sum } \\
\text { of Fractions }\end{array}$ \\
\hline $\mathrm{H}-3^{(\mathrm{a})}$ & $2.6 \mathrm{E}+08$ & $3.2 \mathrm{E}-05$ & $3.7 \mathrm{E}+05$ & $2.2 \mathrm{E}-08$ & $3.2 \mathrm{E}-05$ \\
\hline Sr-90 $0^{(a)}$ & $2.8 \mathrm{E}+02$ & $7.3 \mathrm{E}-04$ & $5.8 \mathrm{E}+02$ & $1.0 \mathrm{E}-05$ & 7.4E-04 \\
\hline I-129 & $3.8 \mathrm{E}+04$ & $1.0 \mathrm{E}-07$ & $2.9 \mathrm{E}+04$ & $1.4 \mathrm{E}-09$ & $1.0 \mathrm{E}-07$ \\
\hline Th-232 (a) & $3.0 \mathrm{E}+02$ & $2.9 \mathrm{E}-04$ & $1.3 \mathrm{E}+03$ & $4.0 \mathrm{E}-03$ & $4.3 \mathrm{E}-03$ \\
\hline U-236 $6^{(\mathrm{b})}$ & $2.1 \mathrm{E}+02$ & $1.8 \mathrm{E}-04$ & $5.7 \mathrm{E}+03$ & $1.8 \mathrm{E}-04$ & $3.6 \mathrm{E}-04$ \\
\hline U-234 & $2.0 \mathrm{E}+02$ & $1.9 \mathrm{E}-01$ & $5.3 \mathrm{E}+03$ & $2.8 \mathrm{E}-04$ & $1.9 \mathrm{E}-01$ \\
\hline U-235 & $2.2 \mathrm{E}+02$ & $8.2 \mathrm{E}-03$ & $3.7 \mathrm{E}+03$ & $1.8 \mathrm{E}-05$ & $8.2 \mathrm{E}-03$ \\
\hline U-238 & $2.2 \mathrm{E}+02$ & $1.5 \mathrm{E}-01$ & $2.5 \mathrm{E}+03$ & $5.1 \mathrm{E}-04$ & $1.5 \mathrm{E}-01$ \\
\hline Total & & $3.5 \mathrm{E}-01$ & & $5.0 \mathrm{E}-03$ & $3.6 \mathrm{E}-01$ \\
\hline \multicolumn{6}{|c|}{ (a) Denotes radionuclide only identified in water sample; sediment value generated using program default } \\
\hline
\end{tabular}




\section{E.2 BDAC Screen with Drive Point Data}

One last set of screening analyses were performed on the data from the shallow groundwater samples collected from drive points. Although the BDAC method (DOE 2001) is not directly applicable to subsurface water, the drive point data were combined without regard to sampling depth and maximum radionuclide concentrations were identified and used as input into the screening calculations. This may be viewed as a worse case bounding assessment. The likely depth of bioturbation in this section of the river is probably no more than 10 centimeters, but the shallowest depth monitored was about 50 centimeters, well below the depth that the sampled invertebrates would utilize as habitat. The main drivers for the total sum of fractions are the uranium isotopes in drive point water samples. The drive point data yielded the highest result in the screening exercises (Table E.3), the sum of fractions is below the screening value of 1.0 limits. The 300 Area shoreline using the drive point data, passes this conservative screening.

Table E.3. Results of Drive Point Sampling Data Screening Exercise Using Biota Dose Calculator (only drive point water sample data were used as input)

\begin{tabular}{||l|c|c|c|c|c||}
\hline \multicolumn{1}{|c|}{ Nuclide } & $\begin{array}{c}\text { Water Limit } \\
\text { pCi/L }\end{array}$ & $\begin{array}{c}\text { Water Partial } \\
\text { Fraction }\end{array}$ & $\begin{array}{c}\text { Sediment Limit } \\
\text { pCi/g }\end{array}$ & $\begin{array}{c}\text { Sediment } \\
\text { Partial } \\
\text { Fraction }\end{array}$ & $\begin{array}{c}\text { Combined Sum } \\
\text { of Fractions }\end{array}$ \\
\hline \hline H-3 & $2.6 \mathrm{E}+08$ & $3.3 \mathrm{E}-05$ & $3.7 \mathrm{E}+05$ & $2.3 \mathrm{E}-08$ & $3.3 \mathrm{E}-05$ \\
\hline Tc-99 & $6.7 \mathrm{E}+05$ & $3.9 \mathrm{E}-05$ & $4.2 \mathrm{E}+04$ & $3.1 \mathrm{E}-06$ & $4.2 \mathrm{E}-05$ \\
\hline $\mathrm{U}-234$ & $2.0 \mathrm{E}+02$ & $3.5 \mathrm{E}-01$ & $5.3 \mathrm{E}+03$ & $6.7 \mathrm{E}-04$ & $3.5 \mathrm{E}-01$ \\
\hline $\mathrm{U}-235$ & $2.2 \mathrm{E}+02$ & $2.0 \mathrm{E}-02$ & $3.7 \mathrm{E}+03$ & $5.7 \mathrm{E}-05$ & $2.0 \mathrm{E}-02$ \\
\hline U-238 & $2.2 \mathrm{E}+02$ & $3.0 \mathrm{E}-01$ & $2.5 \mathrm{E}+03$ & $1.4 \mathrm{E}-03$ & $3.1 \mathrm{E}-01$ \\
\hline Total & $6.7 \mathrm{E}-01$ & $2.1 \mathrm{E}-03$ & $6.8 \mathrm{E}-01$ \\
\hline (a) Sediment contribution was estimated using program default distribution coefficients. \\
\hline \multicolumn{7}{|l|}{} \\
\hline
\end{tabular}

\section{E.3 BDAC Species- and Site-Specific Dose Assessments}

Specific dose assessments were performed to more accurately estimate doses to specific biological receptors include terrestrial vegetation, aquatic vegetation, mice, and aquatic organisms. Internal and external pathways were addressed.

\section{E.3.1 Dose to Vegetation}

Dose estimates for sweet clover and mulberry were based on measured concentrations of radionuclides in leaves and stems. Because results for vegetation samples are reported on a dry weight basis, a correction was made to have results on a wet or initial weight basis, then internal dose factors were applied to maximum concentrations (DOE 2001). The dose rates from internally deposed radionuclides in vegetation ranged from 0.7 to $350 \mu \mathrm{rad}$ per day (Table E.4). This compares to a measure external dose rate of $240 \mu \mathrm{rad}$ per day from the shoreline surveys and is well below the $1 \mathrm{rad}$ per day guideline. 
Table E.4. Dose Rates to Riparian Vegetation from Internally Deposited Radionuclides in Vegetation

\begin{tabular}{|c|c|c|c|c|c|c|}
\hline \multirow[b]{2}{*}{ Location } & \multirow{2}{*}{$\begin{array}{l}\text { Vegetation } \\
\text { Type }\end{array}$} & \multicolumn{5}{|c|}{ Dose Rate (rad/d) } \\
\hline & & Sr-90 & Tc-99 & U-234 & U-238 & Total \\
\hline \multirow{2}{*}{$\begin{array}{l}\text { Vernita } \\
\text { Bridge }\end{array}$} & Mulberry & $5.1 \mathrm{E}-06$ & 0 & 0 & 0 & $5.1 \mathrm{E}-06$ \\
\hline & Sweet Clover & $8.9 \mathrm{E}-06$ & 0 & 0 & 0 & $8.9 \mathrm{E}-06$ \\
\hline \multirow{2}{*}{$\begin{array}{l}300 \text { Area } \\
\text { Location } 7\end{array}$} & Mulberry & $7.9 \mathrm{E}-06$ & $2.8 \mathrm{E}-05$ & $1.6 \mathrm{E}-04$ & $1.5 \mathrm{E}-04$ & $3.5 \mathrm{E}-04$ \\
\hline & Sweet Clover & 0 & $7.4 \mathrm{E}-07$ & 0 & 0 & $7.4 \mathrm{E}-07$ \\
\hline \multirow{2}{*}{$\begin{array}{l}300 \text { Area } \\
\text { Location } 7\end{array}$} & Mulberry & $2.7 \mathrm{E}-06$ & $2.5 \mathrm{E}-06$ & $9.5 \mathrm{E}-05$ & $8.1 \mathrm{E}-05$ & $1.8 \mathrm{E}-04$ \\
\hline & Sweet Clover & 4.1E-06 & $1.3 \mathrm{E}-06$ & 0 & 0 & $5.4 \mathrm{E}-06$ \\
\hline \multirow{2}{*}{$\begin{array}{l}300 \text { Area } \\
\text { Location } 11\end{array}$} & Mulberry & $2.2 \mathrm{E}-06$ & $1.2 \mathrm{E}-05$ & 0 & 0 & $1.5 \mathrm{E}-05$ \\
\hline & Sweet Clover & $4.4 \mathrm{E}-06$ & $1.3 \mathrm{E}-06$ & 0 & 0 & $5.7 \mathrm{E}-06$ \\
\hline \multirow{2}{*}{$\begin{array}{l}300 \text { Area } \\
\text { Location } 14\end{array}$} & Mulberry & $2.0 \mathrm{E}-06$ & $6.9 \mathrm{E}-07$ & 0 & 0 & $2.7 \mathrm{E}-06$ \\
\hline & Sweet Clover & $2.7 \mathrm{E}-06$ & $8.4 \mathrm{E}-07$ & 0 & 0 & $3.5 \mathrm{E}-06$ \\
\hline
\end{tabular}

\section{E.3.2 Doses to Milfoil}

The maximum dose to milfoil collected at Location 7 from internally deposited radionuclides was 1.7E-02 rad per day (Table E.5). The dose rate at Vernita from radionuclides internally deposited radionuclides was 1.2E-03 rad per day. The doses were primarily driven by uranium isotopes at both locations. Although no dose limit for aquatic plants has been set by a regulatory agency, the dose rate of $1.0 \mathrm{rad}$ per day for terrestrial plants is likely appropriate.

Table E.5. Dose Rates to Aquatic Vegetation from Measured Activity Internally Deposited in Vegetation (internal dose conversion factors were taken from Biota Dose Calculator)

\begin{tabular}{|c|c|c|c|c|c|c|c|}
\hline \multirow[b]{2}{*}{ Location } & \multirow{2}{*}{$\begin{array}{l}\text { Vegetation } \\
\text { Type }\end{array}$} & \multicolumn{6}{|c|}{ Dose Rate $(\mathrm{rad} / \mathrm{d})$} \\
\hline & & Sr-90 & Tc-99 & $\mathrm{U}-234$ & $\mathrm{U}-235$ & $\mathrm{U}-238$ & Total \\
\hline $\begin{array}{l}300 \text { Area } \\
\text { Location } 7\end{array}$ & Milfoil & 4.7E-06 & $1.1 \mathrm{E}-06$ & $9.1 \mathrm{E}-03$ & $3.4 \mathrm{E}-04$ & 7.3E-03 & $1.7 \mathrm{E}-02$ \\
\hline $\begin{array}{l}300 \text { Area } \\
\text { Location } 11\end{array}$ & Milfoil & $4.2 \mathrm{E}-06$ & $1.5 \mathrm{E}-06$ & $0.0 \mathrm{E}+00$ & $0.0 \mathrm{E}+00$ & $0.0 \mathrm{E}+00$ & $5.7 \mathrm{E}-06$ \\
\hline $\begin{array}{l}300 \text { Area } \\
\text { Location } 14\end{array}$ & Milfoil & $3.2 \mathrm{E}-06$ & $0.0 \mathrm{E}+00$ & $0.0 \mathrm{E}+00$ & $0.0 \mathrm{E}+00$ & $0.0 \mathrm{E}+00$ & $3.2 \mathrm{E}-06$ \\
\hline Vernita Bridge & Milfoil & $4.0 \mathrm{E}-06$ & $0.0 \mathrm{E}+00$ & $6.6 \mathrm{E}-03$ & $2.0 \mathrm{E}-04$ & $4.8 \mathrm{E}-03$ & $1.2 \mathrm{E}-02$ \\
\hline
\end{tabular}




\section{E.3.3 Dose to Animal}

Dose rates were estimated based on uranium concentrations in specific organs (Table E.6). As discussed in Section 7.1, radiochemical analyses of animal samples did not indicate the presence of manmade radionuclides.

Table E.6. Maximum Dose Rates (rad/d) to Aquatic and Riparian Animals from Measured Uranium-238 Internally Deposited in Various Tissues

\begin{tabular}{||l|c|c|c|c||}
\hline \multirow{2}{*}{ Animal/Tissue } & \multicolumn{4}{|c||}{ Location } \\
\cline { 2 - 5 } & $\begin{array}{c}300 \text { Area } \\
\text { Location 7 }\end{array}$ & $\begin{array}{c}300 \text { Area } \\
\text { Location 11 }\end{array}$ & $\begin{array}{c}300 \text { Area } \\
\text { Location 14 }\end{array}$ & Vernita Bridge \\
\hline \hline Mouse/Kidney & $4.9 \mathrm{E}-06$ & $1.4 \mathrm{E}-05$ & $\mathrm{NS}^{(\mathrm{a})}$ & $\mathrm{NS}$ \\
\hline Mouse/Bone & $2.6 \mathrm{E}-05$ & $7.0 \mathrm{E}-06$ & $\mathrm{NS}$ & $\mathrm{NS}$ \\
\hline Sculpin/Bone & $1.3 \mathrm{E}-04$ & $2.0 \mathrm{E}-06$ & $3.7 \mathrm{E}-05$ & $3.7 \mathrm{E}-05$ \\
\hline Sculpin/Kidney & $\mathrm{NS}$ & $\mathrm{NS}$ & $3.3 \mathrm{E}-06$ & $\mathrm{NS}$ \\
\hline Crayfish/Hepato. & $2.7 \mathrm{E}-03$ & $9.4 \mathrm{E}-03$ & $8.5 \mathrm{E}-04$ & $8.2 \mathrm{E}-04$ \\
\hline Clam Soft Tissue & $5.2 \mathrm{E}-03$ & $2.4 \mathrm{E}-03$ & $2.6 \mathrm{E}-04$ & $5.1 \mathrm{E}-04$ \\
\hline (a) NS = No sample. & \multicolumn{4}{l}{} \\
\hline
\end{tabular}

\section{E.3.4 External Doses to Biota from Radionuclides in Columbia River Water}

External dose rates from submersion in water were highest along the shoreline near the 300 Area. The highest calculated average dose rate was 4.0E-07 rad per day and was at Spring 9. The background location, near Vernita Bridge, had the lowest calculated average external dose rate from submersion in Columbia River water, 5.2E-09 rad per day (Table E.7). For comparison, external rates measure in water in Columbia River at Coyote Rapids was about 1.7E-04 rad per day in 1992 (Woodruff et al. 1993). External dose rates attributable to water immersion to not significantly effect the total estimated dose rate, which is attributable to radionuclides deposited in the organisms.

\section{E.3.5 External Doses to Biota from Radionuclides in Shoreline Sediment}

Maximum radionuclide concentrations measured in sediment samples by either the Washington State Department of Health or by PNNL were used to calculate the external dose rates from exposure to Columbia River sediment. External dose rates were calculated as the product of the radionuclide concentration and the dose conversion factor taken from the BDAC (DOE 2002). The maximum external dose rate to biota was estimated at the Location 9 site and was $9.6 \mathrm{E}-05 \mathrm{rad}$ per day, about 4 times greater than the rate estimated at Vernita. The location with the lowest external dose rate from sediments was the Location 14 site (Table E.8). External dose rates attributable to sediment to not significantly affect the total estimated dose rate, which is attributable to radionuclides deposited in the organisms. 
Table E.7. External Dose Rates (rad/d) to Aquatic Organisms from Measured Radioactivity in Columbia River Water

\begin{tabular}{|c|c|c|c|c|c|c|c|}
\hline $\begin{array}{l}\text { Sample Location } \\
\text { (depth, m) }\end{array}$ & Tritium & Tc-99 & U-234 & U-235 & $\mathrm{U}-238$ & Total & $\begin{array}{l}\text { Locatior } \\
\text { Average }\end{array}$ \\
\hline $7(0.25)$ & $6.8 \mathrm{E}-07$ & $1.5 \mathrm{E}-08$ & 1.7E-09 & 1.7E-09 & $1.1 \mathrm{E}-07$ & $8.1 \mathrm{E}-07$ & \multirow[t]{4}{*}{$3.9 \mathrm{E}-07$} \\
\hline $7(0.5)$ & $3.5 \mathrm{E}-07$ & & $5.8 \mathrm{E}-10$ & $9.6 \mathrm{E}-10$ & 3.6E-08 & 3.9E-07 & \\
\hline $7(1.0)$ & $1.9 \mathrm{E}-07$ & & $1.8 \mathrm{E}-10$ & $8.1 \mathrm{E}-11$ & $1.0 \mathrm{E}-08$ & $2.0 \mathrm{E}-07$ & \\
\hline $7(1.5)$ & $1.6 \mathrm{E}-07$ & & $1.4 \mathrm{E}-10$ & $8.1 \mathrm{E}-11$ & 8.7E-09 & $1.7 \mathrm{E}-07$ & \\
\hline $7 \mathrm{DR}(0.25)$ & $1.7 \mathrm{E}-07$ & & 4.7E-10 & $5.9 \mathrm{E}-10$ & $2.9 \mathrm{E}-08$ & $2.0 \mathrm{E}-07$ & \multirow[t]{4}{*}{$1.2 \mathrm{E}-07$} \\
\hline $7 \mathrm{DR}(0.5)$ & $9.2 \mathrm{E}-08$ & & $2.0 \mathrm{E}-10$ & $1.3 \mathrm{E}-10$ & $1.1 \mathrm{E}-08$ & $1.0 \mathrm{E}-07$ & \\
\hline 7 DR (1.0) & 8.7E-08 & & $1.4 \mathrm{E}-10$ & $1.3 \mathrm{E}-10$ & 8.1E-09 & 9.5E-08 & \\
\hline $7 \mathrm{DR}(1.5)$ & 5.9E-08 & & $8.8 \mathrm{E}-11$ & 7.0E-11 & 5.9E-09 & $6.5 \mathrm{E}-08$ & \\
\hline $7 / 9$ & 5.9E-08 & & $1.6 \mathrm{E}-10$ & $1.0 \mathrm{E}-10$ & 8.6E-09 & $6.7 \mathrm{E}-08$ & \\
\hline $9(0.25)$ & 7.3E-07 & 3.3E-08 & $1.0 \mathrm{E}-08$ & $1.1 \mathrm{E}-08$ & $6.4 \mathrm{E}-07$ & $1.4 \mathrm{E}-06$ & \multirow[t]{4}{*}{$4.0 \mathrm{E}-07$} \\
\hline $9(0.5)$ & $8.1 \mathrm{E}-08$ & & $4.3 \mathrm{E}-10$ & $5.8 \mathrm{E}-10$ & 2.7E-08 & $1.1 \mathrm{E}-07$ & \\
\hline $9(1.0)$ & $3.8 \mathrm{E}-08$ & & $1.2 \mathrm{E}-10$ & $1.3 \mathrm{E}-10$ & 8.0E-09 & 4.6E-08 & \\
\hline $9(1.5)$ & $2.0 \mathrm{E}-08$ & & 8.7E-11 & $1.8 \mathrm{E}-11$ & 5.1E-09 & $2.5 \mathrm{E}-08$ & \\
\hline $9 \mathrm{DR}(0.25)$ & $1.2 \mathrm{E}-07$ & & 1.6E-09 & $2.7 \mathrm{E}-09$ & $9.8 \mathrm{E}-08$ & $2.2 \mathrm{E}-07$ & \multirow[t]{4}{*}{$1.6 \mathrm{E}-07$} \\
\hline $9 \mathrm{DR}(0.5)$ & $1.3 \mathrm{E}-07$ & & 1.7E-09 & 3.6E-09 & $1.1 \mathrm{E}-07$ & $2.5 \mathrm{E}-07$ & \\
\hline $9 \mathrm{DR}(1.0)$ & $7.8 \mathrm{E}-08$ & & 5.5E-10 & 7.4E-10 & 3.6E-08 & $1.2 \mathrm{E}-07$ & \\
\hline $9 \mathrm{DR}(1.5)$ & 3.3E-08 & & $1.0 \mathrm{E}-10$ & $9.8 \mathrm{E}-11$ & 5.8E-09 & 3.9E-08 & \\
\hline $9 / 11$ & $1.7 \mathrm{E}-08$ & & $1.8 \mathrm{E}-10$ & $1.8 \mathrm{E}-10$ & $1.2 \mathrm{E}-08$ & $2.9 \mathrm{E}-08$ & \\
\hline $11(0.25)$ & $6.8 \mathrm{E}-08$ & 2.9E-09 & 1.7E-09 & 2.4E-09 & $1.0 \mathrm{E}-07$ & $1.8 \mathrm{E}-07$ & \multirow[t]{4}{*}{ 7.3E-08 } \\
\hline $11(0.5)$ & $2.6 \mathrm{E}-08$ & & $2.3 \mathrm{E}-10$ & $2.6 \mathrm{E}-10$ & $1.4 \mathrm{E}-08$ & 4.0E-08 & \\
\hline $11(1.0)$ & $1.8 \mathrm{E}-08$ & & 4.6E-10 & $5.5 \mathrm{E}-10$ & $2.9 \mathrm{E}-08$ & 4.8E-08 & \\
\hline $11(1.5)$ & $1.1 \mathrm{E}-08$ & & $2.4 \mathrm{E}-10$ & $3.1 \mathrm{E}-10$ & $1.5 \mathrm{E}-08$ & 2.6E-08 & \\
\hline $11 \mathrm{DR}(0.25)$ & $4.8 \mathrm{E}-08$ & & $8.5 \mathrm{E}-10$ & $8.9 \mathrm{E}-10$ & 5.7E-08 & $1.1 \mathrm{E}-07$ & \multirow[t]{4}{*}{ 4.3E-08 } \\
\hline $11 \mathrm{DR}(0.5)$ & $1.2 \mathrm{E}-08$ & & $2.2 \mathrm{E}-10$ & $2.4 \mathrm{E}-10$ & 1.4E-08 & $2.6 \mathrm{E}-08$ & \\
\hline $11 \mathrm{DR}(1.0)$ & $1.1 \mathrm{E}-08$ & & $1.6 \mathrm{E}-10$ & $2.9 \mathrm{E}-10$ & $1.0 \mathrm{E}-08$ & $2.1 \mathrm{E}-08$ & \\
\hline $11 \mathrm{DR}(1.5)$ & $1.1 \mathrm{E}-08$ & & $1.3 \mathrm{E}-10$ & $1.6 \mathrm{E}-10$ & 6.6E-09 & $1.7 \mathrm{E}-08$ & \\
\hline $14(0.25)$ & 7.5E-09 & & $1.5 \mathrm{E}-10$ & $8.4 \mathrm{E}-11$ & $1.0 \mathrm{E}-08$ & $1.8 \mathrm{E}-08$ & \multirow[t]{4}{*}{$1.5 \mathrm{E}-08$} \\
\hline $14(0.25)$ & 4.5E-09 & & $1.4 \mathrm{E}-10$ & $2.1 \mathrm{E}-10$ & $1.0 \mathrm{E}-08$ & $1.5 \mathrm{E}-08$ & \\
\hline $14(0.25)$ & $4.5 \mathrm{E}-09$ & & $1.8 \mathrm{E}-10$ & $1.1 \mathrm{E}-10$ & 9.4E-09 & 1.4E-08 & \\
\hline $14(0.25)$ & 4.5E-09 & & $1.2 \mathrm{E}-10$ & $6.3 \mathrm{E}-11$ & 6.4E-09 & $1.1 \mathrm{E}-08$ & \\
\hline Vernita $(0.25)$ & $0.0 \mathrm{E}+00$ & 2.2E-10 & 7.2E-11 & 3.6E-11 & 5.1E-09 & 5.4E-09 & \multirow[t]{4}{*}{ 5.2E-09 } \\
\hline Vernita $(0.5)$ & $0.0 \mathrm{E}+00$ & & $7.1 \mathrm{E}-11$ & $9.3 \mathrm{E}-12$ & 3.6E-09 & 3.7E-09 & \\
\hline Vernita (1.0) & $0.0 \mathrm{E}+00$ & & $1.2 \mathrm{E}-10$ & $1.2 \mathrm{E}-10$ & 7.9E-09 & 8.1E-09 & \\
\hline Vernita (1.5) & $0.0 \mathrm{E}+00$ & & $7.4 \mathrm{E}-11$ & $9.3 \mathrm{E}-11$ & $3.4 \mathrm{E}-09$ & $3.6 \mathrm{E}-09$ & \\
\hline
\end{tabular}


Table E.8. External Dose Rates (rad/d) to Aquatic or Riparian Organisms from Measured Radioactivity in Columbia River Sediment

\begin{tabular}{|c|c|c|c|c|c|c|c|}
\hline $\begin{array}{l}\text { BDC Dose } \\
\text { Conversion } \\
\text { Factor }^{(a)}\end{array}$ & $3.3 \mathrm{E}-07$ & $9.5 \mathrm{E}-06$ & $2.3 \mathrm{E}-05$ & $6.7 \mathrm{E}-05$ & $2.9 \mathrm{E}-05$ & 2.0E-05 & \multirow{2}{*}{$\begin{array}{c}\text { Total } \\
\text { Dose Rate } \\
\text { (rad/d) }\end{array}$} \\
\hline $\begin{array}{l}\text { Sample } \\
\text { Location }\end{array}$ & U-234 & U-235 & U-238 & Co-60 & Sr-90 & Cs-137 & \\
\hline Location 7 & $8.9 \mathrm{E}-07$ & $1.3 \mathrm{E}-06$ & $5.8 \mathrm{E}-05$ & $4.5 \mathrm{E}-08$ & $3.4 \mathrm{E}-07$ & $1.0 \mathrm{E}-06$ & $6.2 \mathrm{E}-05$ \\
\hline Location 9 & $1.4 \mathrm{E}-06$ & $2.6 \mathrm{E}-06$ & $8.7 \mathrm{E}-05$ & $8.7 \mathrm{E}-07$ & $7.5 \mathrm{E}-07$ & $4.6 \mathrm{E}-06$ & $9.8 \mathrm{E}-05$ \\
\hline Location 11 & $6.1 \mathrm{E}-07$ & $7.2 \mathrm{E}-07$ & $4.1 \mathrm{E}-05$ & $5.4 \mathrm{E}-07$ & $0.0 \mathrm{E}+00$ & $2.2 \mathrm{E}-06$ & $4.5 \mathrm{E}-05$ \\
\hline Location 14 & $1.1 \mathrm{E}-07$ & 9.4E-08 & $8.0 \mathrm{E}-06$ & $0.0 \mathrm{E}+00$ & $0.0 \mathrm{E}+00$ & $1.3 \mathrm{E}-06$ & $9.5 \mathrm{E}-06$ \\
\hline Vernita & $7.6 \mathrm{E}-08$ & $4.6 \mathrm{E}-07$ & $2.0 \mathrm{E}-05$ & $0.0 \mathrm{E}+00$ & $0.0 \mathrm{E}+00$ & $1.2 \mathrm{E}-07$ & $2.1 \mathrm{E}-05$ \\
\hline
\end{tabular}

\section{Appendix E References}

DOE 2002. A Graded Approach for Evaluating Radiation Doses to Aquatic and Terrestrial Biota. Final Technical Standard No. DOE-STD-1153-2002, Office of Environmental Policy and Guidance, Washington, D.C.

Woodruff, R. K., R. W. Hanf, and R. E. Lundgren (eds.). 1993. Hanford Site Environmental Report for Calendar Year 1992. PNL-8682, Pacific Northwest Laboratory, Richland, Washington. 


\section{Distribution}

No. of

\section{Copies}

\section{OFFSITE}

L. Albin

Division of Radiation Protection

Washington State Department of Health

P.O. Box 47827

Olympia, WA 98504-7827

N. Buske

The Radio Activist Campaign

7312 N.E. North Shore Road

Belfair, WA 98528

T. E. Carpenter

Government Accountability Project

1511 Third Avenue, Suite 321

Seattle, WA 98101

N. Ceto

U.S. Environmental Protection Agency

Region 10

Office of Environmental Cleanup

Director - Hanford Project Office

1200 6th Avenue

Seattle, WA 98101

A. Fredin

Confederated Tribes of the Colville

Reservation

P.O. Box 150

Nespelem, WA 99155

R. Gay

Confederated Tribes of the Umatilla Indian

Reservation

P.O. Box 638

Pendleton, OR 97801
No. of

Copies

L. Goldstein

Hanford Natural Resources Trustee Council

Washington State Department of Ecology

P.O. Box 47600

Olympia, WA 98504

G. Hughes

U.S. Fish and Wildlife Service

3250 Port of Benton Boulevard

Richland, WA 99352-1670

R. Jaquish

1232 Vintage Avenue

Richland, WA 99352

R. Jim, Manager

Environmental Restoration and Waste

Management Program

The Confederated Tribes and Bands of the Yakama Nation

P.O. Box 151

Toppenish, WA 98948

D. McBaugh (5)

Division of Radiation Protection

Washington State Department of Health

P.O. Box 47890

Olympia, WA 98504-7890

O. Patt, Jr., Council Chairman

Confederated Tribes of the Warm Springs

Reservation

P.O. Box 1299

Warm Springs, OR 97761

L. Seelatsee

Wanapum People

P.O. Box 878

Ephrata, WA 98823

Distr.1 
No. of

Copies

P. Sobotta, Director

ERWM

Nez Perce Tribe

P.O. Box 365

Lapwai, ID 83540

E. Stensgar, Chairman

Coeur d'Alene Tribal Council

P.O. Box 408

Plummer, ID 83851-9704

S. P. Van Verst (10)

Division of Radiation Protection

Washington State Department of Health

P.O. Box 47827

Olympia, WA 98504-7827

\section{ONSITE}

\section{DOE Richland Operations Office}

B. Bilson

A3-04

R. A. Carlson

$\mathrm{H} 0-17$

K. V. Clarke

P. F. Dunigan, Jr.

W. M. Glines

J. B. Hall

R. D. Hildebrand

K. A. Klein

A. Larsen

M. K. Marvin

J. G. Morse

L. L. Piper

M. H. Schlender

K. M. Thompson

D. C. Ward (3)

S. H. Wisness

J. H. Zeisloft

DOE Public Reading Room (2)

3 Bechtel Hanford, Inc.

P. G. Doctor

$\mathrm{H} 0-23$

K. A. Gano

H0-23

R. W. Ovink

A5-58

A2-15

A2-15

$\mathrm{H} 0-12$

A7-50

A2-15

A7-75

A6-38

A6-37

A7 -50

A6-38

A2-15

A2-15

A2-15

$\mathrm{H} 2-53$

H9-01
No. of

Copies

CH2M HILL Hanford Group, Inc.

S. K. Muns

H9-03

Duratek Federal Services Northwest

L. P. Diediker N1-24

2 Fluor Hanford, Inc.

J. V. Borghese E6-35

A. R. Johnson H5-26

2 U.S. Environmental Protection Agency

M. Goldstein B5-01

L. E. Gadbois B5-01

2 Washington State Department of Ecology

D. Goswami B5-18

J. W. Yokel B5-18
42 Pacific Northwest National Laboratory

E. J. Antonio (3) K3-54

A. L. Bunn K6-85

R. L. Dirkes K6-75

B. G. Fritz K6-75

R. H. Hanf K6-75

J. W. Lindberg K6-81

S. P. Luttrell K6-96

L. F. Morasch K6-86

G. W. Patton (10) K6-75

T. M. Poston (10) K6-75

K. Rhoads K3-54

B. L. Tiller (6) K6-85

Hanford Site Administrative Record H6-08 Hanford Technical Library (2) P8-55

Historical File - T. M. Poston K6-75

LMSI Central Files A3-88 